UNIVERSIDADE DE SÃO PAULO

ESCOLA DE COMUNICAÇÕES E ARTES

ALEXANDRE TADEU DOS SANTOS

Ficção e antificção na telenovela brasileira: a hibridação do formato e a aproximação com o gênero docudrama. 
ALEXANDRE TADEU DOS SANTOS

\section{Ficção e antificção na telenovela brasileira: a hibridação do formato e a aproximação com o gênero docudrama.}

Tese apresentada ao Programa de Pós-Graduação em Ciências da Comunicação da Escola de Comunicações e Artes da Universidade de São Paulo, como requisito parcial para a obtenção do Titulo de Doutor em Ciências da Comunicação, na área de concentração: Teoria e Pesquisa em Comunicação

Orientadora: $\operatorname{Prof}^{\mathrm{a}}$. Dr ${ }^{\mathrm{a}}$.

Maria Immacolata Vassallo de Lopes 
Autorizo a reprodução e divulgação total ou parcial deste trabalho, por qualquer meio convencional ou eletrônico, para fins de estudo e pesquisa, desde que citada a fonte.

Catalogação da Publicação

Biblioteca da Escola de Comunicações e Artes

Universidade de São Paulo

Santos, Alexandre Tadeu dos

Ficção e antificção na telenovela brasileira: a hibridação do formato e aproximação com o gênero docudrama / Alexandre Tadeu dos Santos. - - São Paulo : A. T. Santos, 2010.

$229 \mathrm{p}$.

Tese (Doutorado) - Departamento de Comunicações e Artes/Escola de Comunicações e Artes/USP, 21/06/2010.

Orientadora: Prof ${ }^{a}$. Dr ${ }^{a}$. Maria Immacolata Vassallo de Lopes

Bibliografia

1. Telenovela. 2. Docudrama. 3. Hibridação. 4. Fait divers 5. Antificção. I. Lopes, Maria Immacolata Vassallo de II. Título.

CDD 21.ed. - 791.45 
SANTOS, Alexandre Tadeu dos

Ficção e antificção na telenovela brasileira: a hibridação do formato e aproximação com o gênero docudrama.

Tese apresentada à Escola de Comunicações e Artes da Universidade de São Paulo para obtenção do título de Doutor em Ciências da Comunicação.

Aprovado em:

Banca Examinadora

Prof. Dr.

Instituição:

Julgamento: Assinatura:

Prof.Dr. Instituição:

Julgamento: Assinatura:

Prof.Dr. Instituição:

Julgamento: Assinatura:

Prof.Dr. Instituição:

Julgamento: Assinatura:

Prof.Dr. Instituição:

Julgamento: Assinatura: 


\section{AGRADECIMENTOS}

Agradeço à professora Dra Maria Immacolata Vassallo de Lopes pelos ensinamentos, por compartilhar seus conhecimentos e por me guiar através do percurso científico.

À professora Dr ${ }^{a}$ Lucrécia D’Aléssio Ferrara e Prof Dr Henri Pierre Arraes de Alencar Gervaiseau pelas pontuais contribuições que guiaram de modo definitivo esta investigação.

Aos eternos amigos do CTVN - Centro de Estudos de telenovela da Universidade de São Paulo, em especial a Alejandra Pia Nicolosi, Denise Oliveira Freire e Maria Cristina Palma Mungioli.

À Adriana Pierre Coca pela amizade e hospitalidade, à equipe do Globo Universidade e a todos aqueles que colaboraram direta ou indiretamente na concretização deste trabalho. 
O realismo aqui, não pode, pois,ser a cópia das coisas, mas o conhecimento da linguagem; a obra mais "realista" não será aquela que "pinta" a realidade, mas aquela que, servindo-se do mundo como conteúdo (este conteúdo é, aliás, estranho à sua estrutura, isto é, ao seu ser), explorar o mais profundamente possível a realidade irreal da linguagem.

Roland Barthes (Ensaios críticos) 


\section{RESUMO}

SANTOS, Alexandre Tadeu dos. Ficção e antificção na telenovela brasileira: a hibridação do formato e a aproximação com o gênero docudrama. 2010. 229f. Tese (doutorado) Escola de Comunicações e Artes, Universidade de São Paulo, São Paulo, 2010.

Com o propósito de discorrer em que medida a telenovela brasileira se aproxima do docudrama ao desenvolver narrativas híbridas entre a ficção e a realidade, este trabalho investiga a origem e os mecanismos de funcionamento desse gênero ainda pouco explorado pela comunidade científica. Partindo de uma periodização, já proposta e consolidada em outras investigações, avançamos na hipótese de que a telenovela brasileira, na contemporaneidade, acelerou o processo de hibridação do formato, iniciado desde sua origem, ao combinar e mesclar linguagens e formatos de diversas ordens. O docudrama é um gênero audiovisual híbrido composto por convenções formais do documentário com o drama, mais especificamente o melodrama. A partir da proposta de leitura de documentários, formulada pelo cineasta francês Roger Odin, que nos permite identificar, no nível da imagem, uma estrutura estilística típica dos documentários, pensamos numa proposta de leitura específica de docudramas. Através da análise de programas como Linha Direta e Por Toda Minha Vida, identificamos características comuns ao gênero: uso intensivo de referentes (fotografias, imagens de arquivo, depoimentos) misturados com a dramatização de fatos reais. Tal qual um fait divers, uma espécie de crônica adaptada ao romance-folhetim e que fez grande sucesso entre os leitores no século XIX, os docudramas apresentam temáticas que priorizam tragédias, crimes, acidentes e assuntos de repercussão popular. Com base nessas razões, a pesquisa segue para a telenovela brasileira para verificar em que medida esse formato de ficção seriada aproxima-se do docudrama ao trazer fatos e pessoas "reais" para a ficção. Esta investigação parte da premissa de que a telenovela brasileira encontra-se num período que denominamos de "novelas híbridas" que apresenta narrativas em sintonia com o período histórico, político, social e econômico pautados por um processo de globalização em curso nas quais as fronteiras comerciais e culturais tornam-se mais tênues. Nesse contexto, a telenovela brasileira, reconhecida nacional e internacionalmente, pela qualidade técnica e de criação, viaja pelo mundo representando a cultura do país e divulgando seu modo de produção dessa modalidade de ficção seriada que, cada vez mais, cria histórias baseadas em fatos reais na contramão da ficção: a antificção.

Palavras-chave: Telenovela. Docudrama. Hibridação. Fait divers. Antificção. 


\begin{abstract}
SANTOS, Alexandre Tadeu dos. Fiction and anti-fiction in Brazilian telenovela: a hybridization format and approach to the docudrama genre. 2010. 229f. Tese (doutorado) - Escola de Comunicações e Artes, Universidade de São Paulo, São Paulo, 2010.
\end{abstract}

With the purpose to discuss the extent to which Brazilian telenovela approaches is close to docudrama while developing fiction and reality hybrid narratives, this paper investigates the origin and the mechanisms of this genre still largely unexplored by the scientific community. Starting with a timeline, already proposed and consolidated in other investigations, we further hypothesized that the Brazilian telenovela, in contemporary times, accelerated the hybridization of the format, launched from its origin to combine and merge languages and formats of various orders. The docudrama is an audiovisual hybrid genre composed of formal conventions of the documentary with the drama, specifically the melodrama. From the reading of the proposed documentary, made by French filmmaker Roger Odin, which allows us to identify the level of the image, a stylistic structure typical of documentaries, we proposed a specific reading of docudramas. Through the analysis of shows such as Linha Direta and Por Toda Minha Vida, characteristics common to the genre: the intensive use of referents (photographs, archival images, testimonies) mixed with the dramatization of actual events were identified. Like a fait divers, a kind of chronicle adapted to paper-novel and that was a big hit among readers in the nineteenth century, the docudramas have themes that prioritize tragedies, crimes, accidents and issues of popular repercussion. Based on these reasons, the search goes to the Brazilian telenovela to see to what extent the format of serial fiction approaches the docudrama to bring facts and real people into fiction. This research assumes that the Brazilian telenovela is set in a period we call "hybrid telenovelas" that present narratives in line with the historical, political, social and economic period guided by an ongoing globalization process in which commercial and cultural borders become more tenuous. In this context the Brazilian telenovela, recognized nationally and internationally for the quality and technical creation, travels the world representing the country's culture and spreading its mode of production of this type of fiction serial that increasingly creates stories based on real facts counter to the fiction: the anti-fiction.

Keywords: Telenovela. Docudrama. Hybridization. Fait divers. Anti-fiction. 


\section{SUMÁRIO}

INTRODUÇÃ

CAPÍTULO I:

Do tradicional ao contemporâneo: uma proposta de periodização da telenovela brasileira

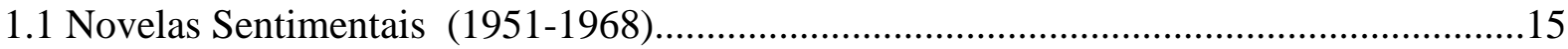

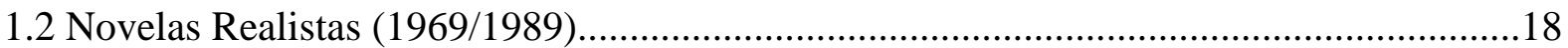

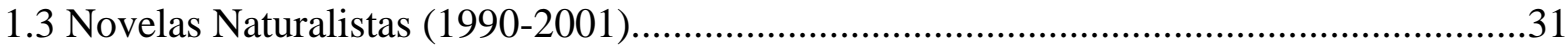

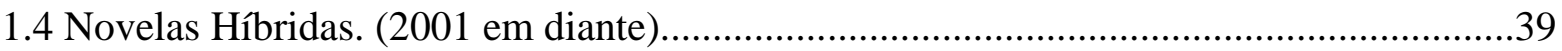

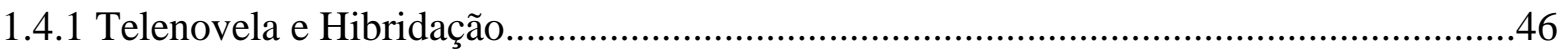

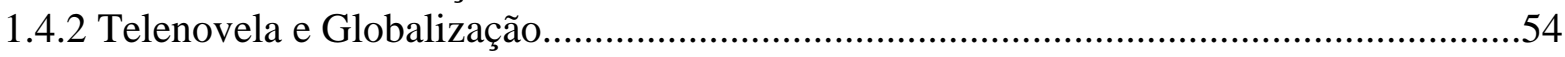

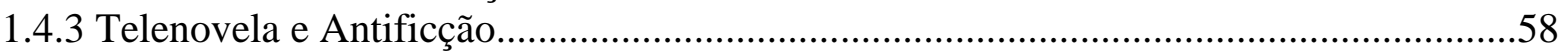

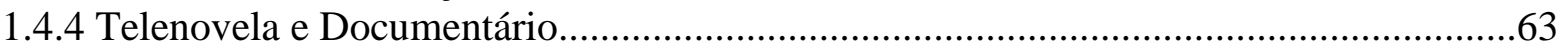

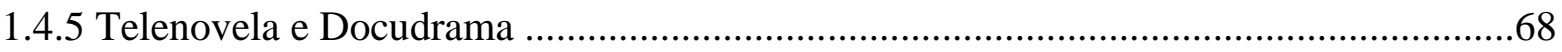

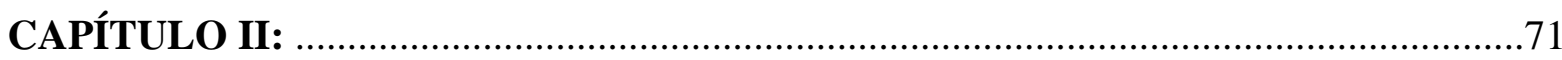

Afinal, o que é docudrama?

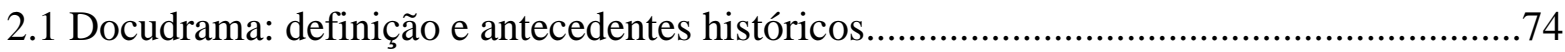

2.2 Fait divers como matriz temática e estrutural do docudrama..........................................90

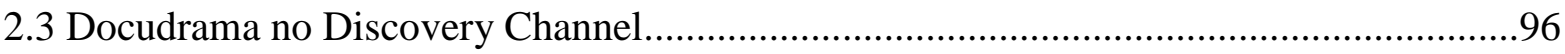

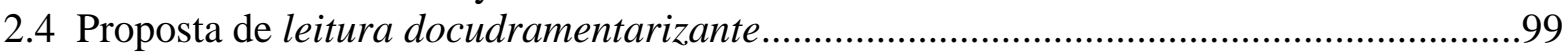

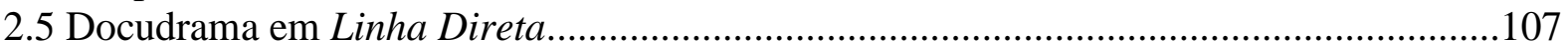

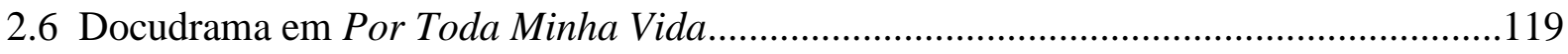

2.7 Exemplos de filmes que podem ser lidos como docudramas........................................123

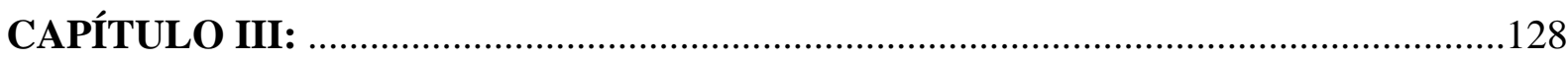

Docudrama na Telenovela: Qualquer semelhança com fatos e pessoas reais é mera coincidência?

3.1 Desconstrução do modelo tradicional da telenovela.....................................................131

3.2 Telenovela brasileira entre a ficção e a realidade..........................................................145

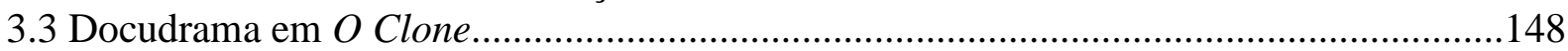

3.4 Docudrama em Páginas da Vida: a representação do 11 de setembro..............................152

3.4.1 Estrutura de relatos e depoimentos: Incêndio de um ônibus no Rio de Janeiro e a morte

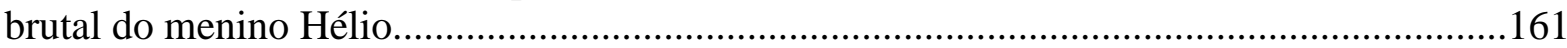

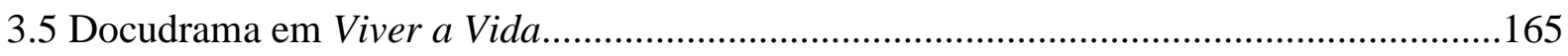

CONCLUSÃO

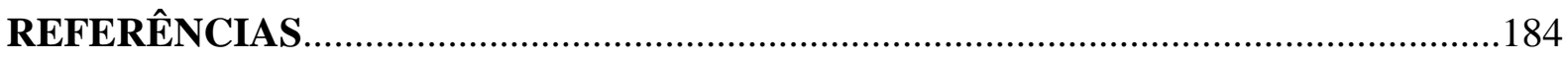

ANEXO A: Transcrição de palestra conferida por Glória Perez .................................192

ANEXO B: Transcrição de entrevista de Glória Perez...............................................221 


\title{
INTRODUÇÃO
}

Há quase seis décadas, a telenovela brasileira faz parte do cotidiano do país. É um sucesso sem precedentes que produz narrativas capazes de seduzir uma cativa audiência habituada a acompanhar cerca de 200 capítulos exibidos em seis dias por semana. Não resta dúvida que essa forma de ficção seriada representa o principal produto da indústria cultural brasileira, tanto em termos de investimentos quanto de índices de audiência ${ }^{1}$. Dentre todas as redes de televisão brasileiras, a TV Globo é a que soube, desde sempre, produzir com competência artística e técnica esse formato da teledramaturgia nacional. Nessa perspectiva, é inevitável falar de telenovela brasileira sem fazer referência ao padrão de produção consolidado pela TV Globo que convencionou transmitir, em sua grade de programação, três novelas diárias: às das 18h, geralmente com histórias de época, às das $19 \mathrm{~h}$ com produções leves nas quais predomina o gênero comédia e as das 21 horas com temáticas mais sérias e tramas melhor elaboradas. Autores consagrados como Janete Clair, Ivani Ribeiro e Dias Gomes deixaram marcas na história da ficção televisiva do Brasil. Atualmente, a manutenção dessa tradição está sob a responsabilidade de autores como Glória Perez, Manoel Carlos, Sílvio de Abreu, Gilberto Braga, Aguinaldo Silva e João Emanuel Carneiro que se revezam na escrita das novelas das 21 horas.

\begin{abstract}
A telenovela, ao longo do tempo, transformou-se em um verdadeiro fenômeno nacional, passando a ser o produto que, talvez, melhor capta expressa e alimenta as angústias e ambivalências que marcam as rápidas mudanças vividas pela sociedade brasileira, constituindo-se em um discurso privilegiado do imaginário nacional. Uma verdadeira narrativa da nação capaz de promover discussões públicas sobre dramas privados e conversas privadas sobre acontecimentos públicos. (Lopes, 2009, p.101)
\end{abstract}

Esta investigação elege a telenovela brasileira como o principal objeto de pesquisa. $\mathrm{O}$ foco é dado nas relações cada vez mais frequentes entre a realidade e a ficção, principalmente nas tramas das 21 horas. A partir de uma periodização já proposta por outros investigadores

1 Segundo Lopes (2003, p. 22): "O custo médio de uma novela de 180 capítulos é de 15 milhões de dólares, o que significa cerca de 80 mil dólares por capítulo. O capítulo diário possui, em média, 34 cenas gravadas, o que corresponde a $1 / 2$ filme de cinema. São 20 horas de gravação e 27 horas de edição para um capítulo de 45 minutos no ar. Normalmente, uma novela tem 60 a $70 \%$ de gravações em estúdio e de 30 a $40 \%$ de gravações externas. A produção envolve uma média de 200 pessoas e uma novela de sucesso alcança por volta de 45 pontos, representando uma média de 32 milhões de espectadores e um share (porção de público total) de $58 \%$." 
que identificaram as tendências das novelas desde seu início na década de 1950, lançamos a hipótese de que essa forma de ficção seriada tem engendrado tramas híbridas entre a ficção e outros formatos tradicionais de representação da realidade, principalmente, o telejornal. Com efeito, assuntos de interesse nacional são representados nas tramas ficcionais como se a telenovela fosse uma extensão de um telejornal. Manchetes como Dos jornais para os folhetins - autores se inspiram fatos reais para a elaboração das tramas na teledramaturgia (Jornal Gazeta do povo, caderno revista da TV, 07/10/2007) ilustram bem essa questão. Na história recente da telenovela brasileira exemplos não faltam: em 26/04/2008, a novela Duas Caras, de Aguinaldo Silva, apresentou uma cena inspirada na tragédia do ônibus 174, ocorrida no Rio de Janeiro, na qual morreu o sequestrador Sandro Barbosa do Nascimento, que tinha feito como refém a professora Geísa Firmo Gonçalves. Na ficção, o personagem Ronildo (Rodrigo Hilbert) faz Solange (Sheren Menezes) como refém dentro de um ônibus e acaba morto. Em 2002, o diretor José Padilha filmou o documentário Ônibus 174, baseado em imagens de arquivo, documentos oficiais e entrevistas.

Para muito além dos assuntos de interesse tradicional dos noticiários, a telenovela apresenta narrativas produzidas de uma forma estética que lembram o gênero docudrama, nas quais pessoas "reais" registram seus depoimentos de vida olhando diretamente para a câmera de TV e imagens de arquivo dos noticiários misturadas com as da ficção. $\mathrm{O}$ docudrama pode ser definido como um gênero que combina, em sua estrutura narrativa, aspectos estéticos dos tradicionais documentários com o melodrama e o "docudrama covers an amazing variety of dramatic forms, bound togheter by two things. They are all based on or inspired by reality, by the lives of real people, or by events that happened in the recente or not too distant past" (Rosenthal, 1999, p. XV).

Partimos do pressuposto que, a partir de $O$ Clone (Globo, 2001), a telenovela brasileira inaugura uma nova tendência e uma nova periodização que neste estudo denominaremos de novelas híbridas. Tratam-se de produções que além de representar assuntos pertinentes ao cotidiano do país, trouxeram o real, ou elementos exteriores à ficção, ao folhetim de maneira mais incisiva com inserção de cidadãos comuns e, portanto não atores, na trama ficcional. É o caso dos depoimentos de vítimas das drogas que se misturavam com elementos da ficção tornando-se uma marca registrada da referida novela. Essa mistura entre o real e o factual ou, em última análise, a combinação entre o documental e o melodrama acaba por reforçar a necessidade de investigação da telenovela enquanto formato híbrido. A hibridação representa 
um dos pontos conceituais centrais desta pesquisa na medida em que nos permite operacionalizar, classificar e compreender, em parte, os mecanismos de funcionamento do docudrama, gênero híbrido entre o documentário e o melodrama, cujas características convencionais e tradicionais de cada termo se combinam formando uma nova estrutura ou uma nova prática.

Correspondente do fait divers nas telenovelas, o melodrama constitui a mais eloquente expressão do sincretismo da cultura de massa na América Latina. Em seus primeiros anos, a novela na TV brasileira simplesmente repetiu um modelo melodramático latino-americano. A partir dos anos 60, dramaturgos brasileiros encontram na telenovela uma alternativa para, driblar os censores, e expor em fragmentos suas críticas sociais. Reforça-se, assim, a concepção de uma estética baseada na alternância da ficção e da realidade. (Rezende, 2005, p.2)

Nesse sentido, a seguinte questão se impõe: de que modo a telenovela brasileira contemporânea pode ser caracterizada como um formato híbrido que se aproxima do gênero docudrama ao retratar ou reapresentar pessoas ou fatos "reais" em suas tramas?

Com vistas a observar o fenômeno da telenovela brasileira e sua possível aproximação com o gênero docudrama, este trabalho delimita como amostragem os trabalhos de autoria dos escritores Glória Perez e Manoel Carlos. A escolha justifica-se em razão desta investigação entender que os escritores acima citados são os que articulam, de maneira mais explícita, o factual com a ficção. De Glória Perez, selecionamos $O$ Clone (Globo, 2001) e de Manoel Carlos, Páginas da Vida (Globo, 2006) e Viver a Vida (Globo, 2009). Muito embora essas novelas constituam a amostragem deste trabalho, no decorrer da tese, ilustraremos alguns momentos clássicos da teledramaturgia brasileira fortemente lembrados por fazer referências diretas ao factual. Especial atenção é dedicada aos programas Linha Direta (Globo, 19992005) e Por Toda Minha Vida (Globo, 2006-2009), docudramas nacionais que mais representam o gênero na televisão brasileira. A estratégia é compreender quais características comuns devem conter um material audiovisual para ser considerado docudrama.

Este trabalho parte de uma pesquisa bibliográfica, uma vez que busca abordar o problema a partir de referências em artigos, livros, teses e dissertações combinada com a pesquisa descritiva porque visa observar e correlacionar as variáveis: telenovela brasileira, hibridação e docudrama. Por ser o docudrama um primo próximo do documentário segundo Ramos (2008, p.55), a estratégia desta investigação é a de contemplar consagrados estudos 
feitos pelo cinema sobre documentário a exemplo de Nichols, (2007), Da-Rin (2004), Costa (2005) e Ramos (2008). Em relação ao melodrama: Thomasseau (2005), Brooks (1995), Meyer (1996) e Martín-Barbero (2003).

Organizamos o trabalho em três capítulos: o primeiro Do tradicional ao contemporâneo: uma proposta de periodização da telenovela brasileira tem como objetivo resgatar na história da telenovela brasileira tendências estéticas de produção do formato desde seu início em 1951: as novelas sentimentais nas quais predominavam as estéticas narrativas herdadas do rádio e do folhetim clássico do século XIX; as novelas realistas que trouxeram o cotidiano do país para dentro de suas histórias; as novelas naturalistas caracterizadas pelas inserções de merchandising social e, por fim, as novelas híbridas, fortemente marcadas pela mistura entre a realidade e a ficção e que absorvem as mudanças conceituais e tecnológicas do mundo contemporâneo. A inspiração do termo novelas híbridas que ora propomos é creditada a Garcia Canclini (2003) em sua obra Culturas Híbridas, na qual o autor define o conceito nos seguintes termos: "entendo por hibridação processos socioculturais nos quais estruturas e práticas discretas, que existiam de forma separada, se combinam para gerar novas estruturas, objetos e práticas" (Canclini, 2003, p. XIX). Defendemos que as novelas desse novo período apresentam inovações no formato e estão em sintonia com o contexto da globalização, em que identificamos uma cultura mundializada (Ortiz, 2006) e profundas mudanças estruturais na sociedade que, acreditamos, interferem diretamente nas mudanças observadas na telenovela. No segundo capítulo: afinal, o que é docudrama? investigamos as origens e as características narrativas desse gênero. Como ponto de partida, nos apoiamos nas investigações de Rosenthal (1999), Maqua (1992) e Fuenzalida (2008) e identificamos os fait divers como matriz temática do gênero. Acabamos por propor uma forma de leitura de docudramas que cunhamos de leitura docudramentarizante apoiada nas investigações acerca do documentário cinematográfico defendidas por Odin (1984) e, por fim, no capítulo 3: Docudrama na Telenovela: Qualquer semelhança com fatos e pessoas reais é mera coincidência? levamos a discussão para a telenovela afim de compreender melhor a representação do "real" nesse formato da teledramaturgia brasileira que, cada vez mais, desconstrói o modelo tradicional do folhetim do século XIX, rompendo com dicotomias clássicas consagradas pelo gênero e que busca inovar e manter-se em sintonia com o mundo contemporâneo. 


\section{Capítulo 1}

\section{Do tradicional ao contemporâneo: uma proposta de periodização da telenovela brasileira.}

É notável como a telenovela brasileira tem despertado o interesse cada vez maior da comunidade acadêmica que passa a encará-la com um importante objeto de estudo. O estado da questão sobre os estudos desse formato $^{2}$ de ficção televisiva aponta um crescimento bastante significativo da pesquisa da telenovela. Em toda a década de 80, estão registradas somente 9 pesquisas ( 8 de mestrado e 1 de doutorado), ao passo que, em apenas cinco anos (2000 a 2005), foram defendidas 80 pesquisas (64 dissertações 16 teses de doutorado) ${ }^{3} \mathrm{Se}$ considerarmos que estes dados consideram apenas as dissertações e teses defendidas em programas de pós-graduação em comunicação, acreditamos que este número seja bem maior se levarmos em consideração as pesquisas sobre telenovela defendidas em outras áreas. Estes estudos abrigam diversas abordagens temáticas: relações de gênero, política, educação, saúde, entre outros.

Estudos realizados pelo OBITEL ${ }^{4}$ apontam a telenovela como o formato mais produzido, em número de horas de produção, entre os países que compõem a rede de pesquisa. Das 27.186 horas de ficção televisiva produzidas nesses países nos anos de 2006 a 2008, $71 \%$ ou 19.342 horas são de telenovelas. ${ }^{5}$

2. Sublinhamos que, neste estudo, consideramos a telenovela como um dos formatos da teledramaturgia, gênero ficcional que engloba, além da telenovela, outros formatos tais como: seriado, minissérie e soap opera. Cada um desses formatos possui configurações diferenciadas no que se refere a número de capítulos ou episódios, tempo de duração e estrutura narrativa. Enquanto a telenovela dura em média 200 capítulos, os seriados são apresentados em temporadas e os episódios são independentes na medida em que apresentam histórias que se desenvolvem de maneira completa em um único episódio, ou seja, bastam em si próprios apresentando o começo, meio e desfecho da trama. As minisséries duram em média de 5 a 20 capítulos e "é uma obra fechada, definida em sua história, peripécias e final, no momento em que se vai para a gravação. Não comporta, em geral, modificações - como a telenovela de modelo brasileiro - a serem feitas no decurso do processo e do trabalho. “ (Pallottini, 1998, p. 28). Já as soap operas são mais comuns nos Estados Unidos e são produções que permanecem no ar durante anos. No Brasil, Malhação é a única representante desse formato ficcional e está no ar desde 1995.

3. Segundo dados de pesquisa do CTVN - Centro de Pesquisa em Telenovela da Escola de Comunicações e Artes da USP.

4. Observatório Ibero-americano da Ficção Televisiva que reúne equipes de pesquisadores da Argentina, Brasil, Chile, Espanha, Estados Unidos, México, Portugal e Uruguai, com o objetivo de monitorar dados quantitativos e qualitativos sobre a produção e exibição de ficção televisiva nestes países. Os resultados dessas pesquisas foram publicados até o momento em três anuários OBITEL, a saber: Culturas y mercados de la ficción televisiva en iberoamérica (2007) , Mercados globais, histórias nacionais (2008) e A ficção televisiva em países iberoamericanos: narrativas, formatos e publicidade (2009)

5. Idem p. 35. 
No Brasil, a proporção é ainda maior: das 5.331 horas de ficção televisiva produzidas no mesmo triênio, $85,4 \%$ - 4.553 horas são de telenovelas, contra 7,1 \% - 377 horas de outros formatos ficcionais (docudramas, unitários, soap operas e microsséries) 5,8\% - 311 horas de série e $1,7 \%$ - 90 horas de minisséries. ${ }^{6}$

Isso posto, o presente capítulo tem por objetivo investigar como a telenovela tornou-se o produto televisual mais produzido, em número de horas e exibição, e de maior audiência da indústria da cultura no Brasil. Partindo de seu início, em 1951, e chegando aos dias de hoje, as reflexões aqui expostas serão organizadas de forma a periodizar seu percurso histórico. Será ressaltada a importância deste formato no processo de consolidação da maior rede de televisão da América Latina; a TV Globo, cuja profissionalização e o chamado padrão de qualidade construíram o que conhecemos hoje como telenovela brasileira ${ }^{7}$. Na persecução deste objetivo, busca-se precisar períodos do desenvolvimento do formato que passaremos a explorar mais adiante.

Cabe enfatizar que a periodização da telenovela brasileira foi contemplada em diversos outros estudos, entre os quais destacamos: Campedelli (1985), Ortiz, Borelli e Ramos Ortiz (1989), Mattelart e Mattelart (1989), Hamburguer (2004) e Lopes (2009). Em última análise, esses estudos demonstram que a telenovela brasileira pode ser periodizada em três momentos que foram pensados a partir de tendências que marcaram a produção do formato sempre em consonância com o contexto sócio-cultural do país.

O primeiro período, de 1951 a 1968, que pode ser denominado de novelas sentimentais, englobaria novelas melodramáticas fortemente apoiadas no folhetim clássico tradicional. O segundo período, de 1969 a 1989, com as novelas realistas, em sintonia com as temáticas de um país em processo de modernização, e o terceiro momento, de 1990 em diante, com as novelas naturalistas em que as obras acoplam em suas tramas campanhas sociais que passaram a ser conhecidas como merchandising social. Assumindo essa perspectiva,

6. Ibidem p. 34.

7. Lopes (2009, p. 22) define a telenovela brasileira como uma narrativa ficcional de serialidade longa, diária e que dura aproximadamente 200 capítulos no ar, ou seja, é exibida de segunda à sábado e dura em média 8 meses: “ao usarmos a expressão"telenovela brasileira" referimo-nos efetivamente ao padrão de teledramaturgia atingido e popularizado pela TV Globo, incorporando a importância que tiveram na consecução desse padrão tanto a experiência pioneira da TV Tupi (décadas 1964-1980) e a experiência inovadora da TV Manchete (1984-1998)". Motter (2003, p. 43) denomina de telenovela brasileira um tipo de produção que representa a realidade concreta reconstruída por um autor e que, nessa perspectiva, também pode ser denominada de telenovela de autor "como preferem alguns (por analogia ao "cinema de autor"), eleva-se à condição de agendadora de pautas para a mídia, ampliando as possibilidades de repercussão de suas temáticas sociais, transferindo para os agentes sociais concretos a continuidade do debate, ou a manutenção/aproveitamento de sua lembrança para fins outros, com a promoção de serviços ou venda de produtos". 
propomos uma quarta periodização que denominaremos de Novelas híbridas. Trata-se das tendências das produções de novelas a partir de 2001, que demonstram uma acentuada combinação entre ficção e realidade e uma forte sintonia contextual com o processo de globalização em curso. Ao propor esse quarto período, defendemos que a novela vai além de uma representação da realidade através das inserções de merchandising social ou de inspirar suas tramas em notícias publicadas na grande imprensa. Nessas novelas, observa-se um proposital retrato da realidade com personagens não ficcionais e, ao trazer para ficção personagens da vida real em $O$ Clone (Globo, 2001), América (Globo, 2005), Páginas da Vida (Globo, 2006) e Viver a Vida (Globo, 2009), entre outros, o formato inaugura uma nova tendência que acaba por mesclar características estilísticas do documentário com as tramas ficcionais.

Para Lopes (2003, p. 25):

\begin{abstract}
Alçada à posição de principal produto de uma indústria televisiva de grandes proporções, a novela passou a ser um dos mais importantes e amplos espaços de problematização do Brasil, das intimidades privadas às políticas públicas. Essa capacidade sui generis de sintetizar o público e o privado, o político e o doméstico, a notícia e a ficção, o masculino e o feminino está inscrita no texto das novelas que combinam convenções formais do documentário e do melodrama televisivo.
\end{abstract}

De fato, ao longo de quase seis décadas, a telenovela brasileira produziu momentos memoráveis que, em inúmeros exemplos, extrapolou a ficção, Alguns exemplos: em América (2005), novela escrita por Glória Perez, Dudu Braga, filho de Roberto Carlos, cantor romântico mais popular do país, fez uma participação apresentando o programa fictício $E$ preciso saber viver, título de um velho sucesso musical de seu pai, no qual entrevistava pessoas com deficiência visual, como ele próprio, que se destacavam em alguma profissão. Braga interagiu com Jatobá, personagem cego interpretado por Marcos Frota. Ao longo da telenovela, diversas pessoas com deficiência visual foram entrevistadas e, ao final de cada programa, a equipe de produção aparecia em cena para imprimir mais realismo ao momento. Perez também proporcionou uma campanha contra as drogas na novela $O$ Clone (2001), quando pessoas, vítimas das drogas, gravaram seus depoimentos no estilo documentário, alertando para as consequências do vício. Em Mulheres Apaixonadas (2003), o autor Manoel Carlos matou uma personagem da trama, vítima de bala perdida. Esta cena motivou mais de 40.000 pessoas a participarem de uma passeata pedindo por um Brasil sem armas. Cenas reais da passeata foram exibidas na ficção. 
Em 2006, Manoel Carlos, na novela Páginas da Vida, optou por realizar a transição de cinco anos da trama (de 2001 a 2006), citando os principais assuntos factuais mais relevantes de cada ano. Destaca-se o ataque ao World Trade Center ocorrido em setembro de 2001. No início da sequência e no momento da colisão do primeiro avião com a torre gêmea, a personagem Tonia, interpretada por Sonia Braga, está numa lanchonete com um amigo. Nota-se o reflexo do avião sobre o vidro e cara de perplexidade da personagem como se, de fato, ela estivesse próxima da tragédia. Em 2009, a esquizofrenia foi um dos temas centrais retratados na novela Caminho das Índias, de Glória Perez. Através do personagem Dr Castanho (Stenio Garcia) e dos dramas vividos por Tarso, personagem esquizofrênico, interpretado por Bruno Gagliasso, o público brasileiro pôde acompanhar e, por que não dizer, aprender, de uma maneira bastante didática sobre a esquizofrenia e psicopatismo. Em 21 de agosto de 2009, Glória Perez recebeu homenagem do setor de psiquiatria da Santa Casa de misericórdia e da Associação Psiquiátrica do Estado do Rio de Janeiro, tornando-se sócia benemérita da instituição. Com o retrato da doença na novela, a Santa Casa do Rio de Janeiro teve um aumento de $10 \%$ na procura pelo tratamento da esquizofrenia. ${ }^{8}$ Entretanto, estas campanhas sociais e o retrato do cotidiano do Brasil nem sempre estiveram presentes nas produções do formato. A telenovela brasileira foi se construindo ao mesmo tempo que desconstruía tradições do folhetim clássico. Durante quase sessenta anos, o formato se transformou e continua a se atualizar na medida em que busca, cada vez mais, sintonizar-se com o tempo histórico do momento em que é produzido. E é exatamente esta tendência à maior combinação entre a ficcionalidade e a factualidade que constitui uma das apostas centrais desta investigação, que buscará demonstrar como a telenovela brasileira aproxima-se do gênero docudrama - bastante comum nas televisões chilenas e britânicas - ao inaugurar no formato esse novo estilo. Mas, antes, julgamos importante resgatar as periodizações anteriores já consolidadas em outros estudos.

\subsection{Novelas Sentimentais (1951-1968)}

Denominadas de sentimentais por Lopes (2009), o período de produção dessas novelas já fora denominado de folhetim exótico por Campedelli (198, p. 32) e fase fantasia por Hamburguer (2005, p. 149). "São telenovelas insistentemente ambientadas em paisagens 
alienígenas, distantes, onde atuam personagens excêntricas, extravagantes, quando não esdrúxulas" afirma Campedelli (1985, p.32). O que há de comum entre as produções do gênero no período relatado são o fato de que, em sua grande maioria, foram financiadas por empresas da indústria de saponáceos, adaptações de textos estrangeiros e por estarem ligadas a uma forte marca melodramática herdada do rádio. As novelas sentimentais seguem um modelo tradicional de novela latino-americana:

Entendemos por tradicional aquele tipo de telenovela que, a partir da radionovela cubana, dá forma a um gênero sério, no qual predomina a inclinação trágica. Gênero moldado por um formato que põe em imagens unicamente paixões e sentimentos primordiais, elementares, excluindo do espaço dramático toda ambiguidade ou complexidade histórica e neutralizando, com frequência, as referências de lugar e tempo. (MartinBarbero, 2004, p. 120)

No início das transmissões da televisão no Brasil, na década de 1950, as primeiras novelas ou importavam roteiros dos países latino-americanos, principalmente da Argentina, Cuba e México, financiadas por companhias produtoras de bens higiênicos, tais como Colgate Palmolive , Gessy-Lever e Kolynos-Van Ess, ou eram adaptações de obras literárias brasileiras ou universais, representadas por obras de José de Alencar, Alexandre Dumas, Victor Hugo e Shakespeare, entre outros. As produções desse período traziam em si marcas textuais fortemente herdadas da radionovela e dos folhetins cubanos. Nesse contexto, destacase a novela Sua vida me pertence (Tupi, 1951), de Walter Foster, o título da primeira telenovela brasileira. Dadas as limitações técnicas da época - não havia videotape - os programas deveriam ser exibidos ao vivo, o que impossibilitava sua transmissão diária. Com o desenvolvimento tecnológico, que levou à invenção do videotape em 1960, a indústria televisual intensificou seu ritmo de produção, o que possibilitou a transmissão diária de novelas. 25499 ocupado (Excelsior, 1963), adaptada da ideia original do argentino Alberto Migré e que trazia Tarcísio Meira e Glória Menezes nos papéis principais, foi a primeira telenovela diária da história da televisão brasileira. Outro destaque foi $O$ direito de nascer (Tupi, 1964-1965), escrita pelo cubano Félix Caignet, a telenovela de maior sucesso da década de 1960.

Essa primeira fase da telenovela brasileira (1951 a 1968) é caracterizada por dramalhões fortemente marcados com as características de uma narrativa folhetinesca tradicional e elementos clássicos do melodrama. As novelas produzidas nesse período 
apresentaram estruturas narrativas simplificadas, com poucos personagens e tramas reduzidas que geralmente versavam sobre trágicas histórias de amor, algo muito semelhante do que ainda apresentam as novelas mexicanas.

Os personagens folhetinescos estão distantes da realidade, vivem exageradamente os dramas cotidianos, transfigurando a vida pelo mistério. Neste sentido, eles são mais arquétipos do que modelos que possam inspirar um determinado comportamento a ser seguido pela sociedade (Ortiz et al, 1989, p. 48).

Durante as décadas de 1950 e 1960, a TV Tupi e a TV Excelsior foram as grandes realizadoras de novelas, pioneiras na criação de um produto que viria a se consolidar como um dos mais rentáveis produtos da indústria da cultura na década de 1970. Esse período é conhecido por uma época em que a televisão buscava encontrar seu espaço e era um veículo de comunicação no qual predominavam as improvisações criativas, técnicas, organizacionais e empresariais. Convém ressaltar que nesse período houve um brutal crescimento de números de aparelhos de televisão no Brasil: somente em 1966, foram vendidos 408 mil aparelhos, praticamente a quantidade acumulada durante toda a década de 1950 (Ortiz et al, 1989: 79).

As novelas desse período são tramas que trazem evidentes marcas do folhetim tradicional:

a doméstica numa relação amorosa com o patrão milionário ( $A$ moça que veio de longe); o relacionamento conturbado entre a mãe e a filha que desconhece a verdadeira maternidade (Uma sombra em minha vida); a mulher misteriosa que, num jogo de dupla personalidade, se faz freira durante o dia e dançarina-cigana durante a noite (Alma Cigana); a mulher má com cara de anjo que flerta com um homem casado ( $A$ outra face de Anita); bebês trocados num duelo de culpa e vingança (Somos todos irmãos); a paternidade desconhecida (Direito de nascer). (Ortiz et al, 1989, p. 70)

É sabido que a TV Globo iniciou efetivamente suas atividades em 1965 e, logo depois, contratou a cubana Glória Magadan para escrever novelas. Durante o período em que Magadan permaneceu na Globo - até o final da década de sessenta - a tendência da produção de novelas continuou a ser fantasiosa, com nomes estrangeiros nos personagens, cenários, figurinos e títulos exóticos: O Sheik de Agadir (Globo, 1966), O rei dos ciganos (Globo, 1966) e a Rainha louca (Globo, 1967), entre outros. Ainda no período em que Magadán era responsável pela criação e produção de novelas da TV Globo, Janete Clair, considerada uma das maiores novelistas de todos os tempos, escreveu, nessa mesma emissora, quatro novelas fortemente melodramáticas, a maioria ambientada em terras estrangeiras: Anástacia, a mulher 
sem destino (1967), Sangue e Areia (1967), Passos dos Ventos (1968) e Rosa Rebelde (1969). Ambientada na Espanha nos tempos de Napoleão Bonaparte

\begin{abstract}
Rosa Rebelde foi a última novela da Rede Globo ambientada em países estrangeiros, com época e personagens distantes da realidade brasileira. A trama fez sucesso, mas sofreu forte concorrência de Beto Rockfeller, apresentada no mesmo horário pela TV Tupi, com enredo contemporâneo, de autoria de Bráulio Pedroso. (Ferreira, 2003, p. 42)
\end{abstract}

Em outra oportunidade (Santos, 2003), demonstra que as novelas desse período seguiam o padrão de folhetim tradicional, com os papéis dos vilões e heróis previamente determinados com as clássicas histórias de filhos bastardos, heranças repentinas e amores impossíveis. Tal tendência prevaleceu na produção de novelas até 1968 , com o sucesso da trama contemporânea Beto Rockfeller e com a saída de Magadan da TV Globo, momento definitivo em que as telenovelas passaram a abordar um conteúdo mais realista do Brasil.

Há unanimidade entre os produtores de novelas e as investigações acadêmicas de que a novela Beto Rockfeller representa um marco na história da telenovela brasileira na medida em que rompe com as estéticas vigentes do gênero até aquele momento. Segundo Ortiz et al (1989, p. 78), essa novela "se distancia do melodrama, na medida em que a figura principal é um anti-herói”, representado por Luiz Gustavo, um pobretão que, para subir na vida, é capaz de cometer as mais diversas malandragens. Essa história parcelada rompe com os diálogos formais do folhetim tradicional, introduzindo no texto palavras de cunho coloquial, gírias e expressões tipicamente brasileiras. A partir de Beto Rockfeller, diversas outras histórias foram criadas buscando temas que contemplassem situações que se identificassem, de alguma forma, com a população brasileira. Inicia-se ali um período de mais de duas décadas de produção de telenovelas que, de um certo modo, passou a tematizar o Brasil através de novelas mais "realistas".

\title{
1.2 Novelas realistas $(1969 / 1989)^{9}$
}

9. Esse período foi denominado de telenovela-alternativa por Campedelli (1985) e de nacional-popular por Hamburguer (2005). Campedelli observa que as novelas produzidas a partir de Ninguém crê em mim (Tupi, 1966), de Lauro César Muniz e Bráulio Pedroso, funcionam como uma alternativa ao desenvolvimento de folhetins melodramáticos, com a inserção de diálogos mais coloquiais, tendência consagrada de uma vez por todas pela já mencionada Beto Rockfeller, enquanto Hamburguer afirma que referências a assuntos recorrentes à cultura brasileira, como o futebol, foram integradas às tramas desse período. "É como se essa referência oferecesse ao drama romântico uma âncora histórica e geográfica capaz de atestar a verossimilhança daquelas tramas: elas se referem ao Brasil contemporâneo", afirma Hamburguer (2005, p. 89). 
Ortiz, Borelli e Ortiz Ramos (1989), Mattelart e Mattelart (1989) e Lopes (2009)

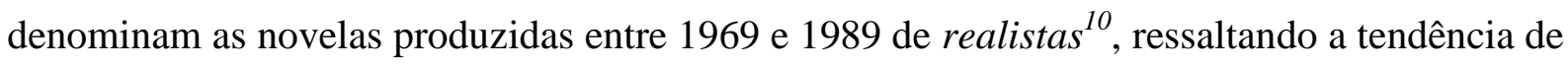
produção do formato a partir da novela Beto Rockfeller.

Este paradigma trouxe a trama para o universo contemporâneo das cidades grandes brasileiras, o uso das gravações externas, introduziu a linguagem coloquial, o humor inteligente, uma certa ambiguidade dos personagens e, principalmente, um repertório de referências compartilhado pelos brasileiros. (Lopes, 2009, p.25)

Com efeito, são produções que buscaram retratar um conteúdo mais "real" do Brasil, iniciando um processo de modernização da telenovela brasileira ainda em curso.

Todavia, o que é o real? Nunca o conhecemos senão sob a forma de efeitos (mundo físico), de funções (mundo social) ou de fantasmas (mundo cultural); em suma o real nunca é ele próprio senão uma inferência; quando se declara copiar o real, isso quer dizer que se escolhe uma inferência e não outra: o realismo é, logo desde o seu aparecimento, submetido à responsabilidade de uma escolha; eis uma primeira má distribuição, própria de todas as artes realistas, logo que lhes supõe uma verdade de certo modo mais bruta e indiscutível que a das outras artes, ditas de interpretação. (Barthes, 2009, p. 186)

As novelas realistas foram produzidas em um contexto histórico, social, político e econômico da sociedade brasileira, em que a ideia de integração resumia, em parte, o objetivo político dos governantes desse período. Integração era a palavra de ordem de um Estado autoritário, legitimado através de um golpe militar, iniciado com a deposição do presidente João Goulart em 1964 e comandado pelo General Costa e Silva. O pós-64 é considerado por especialistas como um marco na história brasileira, isso porque o golpe militar provocou mudanças que vão além da política na sociedade brasileira. Ele ocasionou transformações econômicas que orientaram a sociedade brasileira a um desenvolvimento capitalista específico (Ortiz, 2006). E o quadro econômico do país daquele período apontava para uma concentração de renda, desigual crescimento entre as regiões federativas do país e a concentração da população em grandes centros urbanos, principalmente São Paulo e Rio de Janeiro. Ocorre um aumento do consumo de bens simbólicos produzidos, muitas vezes, sob a

10. Por outras palavras, "realista" faz referência direta ao movimento artístico literário denominado de realismo. "Genericamente, o vocábulo designa toda estética centrada no 'real', entendido como a soma dos objetos e seres que compõem o mundo concreto e social”, diz Moisés ( 2004, p. 378). 
égide de um brutal controle ideológico e político do Estado no campo da cultura. Desse modo, ficou a cargo do Estado a responsabilidade dos investimentos em tecnologias de comunicação e o poder de concessão de redes de televisão a empresas privadas que deveriam agir em sintonia com as leis, decretos e normatizações de um Estado autoritário que ditava as regras em nome de uma segurança nacional da nação. (Ortiz, 2006) Portanto, integrar uma nação formada por terras distantes e com uma diversidade étnica, cultural, social e econômica por meio de uma rede de comunicação, possibilitada por investimentos tecnológicos, era um dos objetivos desse sistema de governo autoritário. Dessa forma,

O Brasil diminuía as fronteiras, integrando um enorme país através das transmissões televisuais. A história da televisão neste imenso Estado federativo que é o Brasil participa da história da integração nacional. A televisão assumirá um papel de vanguarda enquanto agente unificador da sociedade brasileira. (Mattelart e Mattelart, 1989, p. 36)

Nessa perspectiva, a televisão representou um dos poderosos instrumentos de integração da nação e a telenovela, em particular, desempenhou um importante papel nesse processo de unificação da sociedade brasileira, na medida em que passou a tematizar o Brasil, não mais apenas com as temáticas advindas de um folhetim clássico mas, sobretudo, representando o país através de ficções narrativas que dão conta de um espaço público, privado e político da nação com todas as problemáticas de um país que buscava se modernizar e

sem abrir mão da estrutura básica do folhetim - seriação, incompletude, sustentada por uma trama amorosa - que a caracteriza como novela, morfologicamente análoga ao conto maravilhoso, ela transforma-se, moderniza-se. Mudam os temas que perpassam a trama amorosa. As personagens ganham complexidade, interioridade e ambiguidade que se exteriorizam em conflitos, problematizando sujeitos, ações e situações. (Motter, 2003, p. 42)

Com efeito, o cotidiano do Brasil passa a servir de base para as produções do formato: o desenvolvimento das grandes cidades, o êxodo rural, corrupção, divórcio, comportamento dos jovens, entre outros. Dito de outro modo, a novela brasileira passa a "narrar a nação", Ainda no dizer de Hobsbawn (2004, p. 13):

11 . Conforme Anderson (1983) apud HALL(2006.p. 50), 
Não por acaso, o número de trabalhos que genuinamente iluminam a questão a respeito o que são nações e movimentos nacionalistas e qual seu papel no desenvolvimento histórico é maior no período 1968-1988 do que em qualquer período anterior com o dobro dessa duração.

Em verdade, o que há de comum entre as novelas realistas é o rompimento com a estrutura tradicional melodromática das novelas sentimentais com a consequente integração entre o cotidiano do Brasil e a ficção. É um momento da história do gênero onde ocorre uma “cotidianização da narrativa” (Pignatari, 1984: 61) e uma nacionalização da teledramaturgia, é o "eu vejo o Brasil na telenovela" (Lopes, 2003, p. 24). Temos, portanto, o contraponto entre dois modelos que, segundo Martin-Barbero (2004), dominaram o mercado latino-americano de telenovelas - o tradicional (novelas mexicanas e venezuelanas) e o moderno (telenovela brasileira). Se o modelo tradicional dominou a produção de novelas em sua primeira fase sentimental, o modelo moderno se consolida na fase realista. Durante esse período (19691989), somente na TV Globo (ver tabela 1 p. 26), foram produzidas para os horários das 20h e $22 \mathrm{~h}$ cerca de 50 novelas ( 34 para o horário das $20 \mathrm{~h}$ e 16 no horário das $22 \mathrm{~h}$ ), que passaram a mapear temáticas do Brasil. Num período fortemente marcado pela intervenção do Estado em diversos aspectos da cultura e com a censura prévia dos meios de comunicação de massa, os autores de telenovela, em sua maioria partidários de uma política de esquerda, como Dias Gomes, retrataram as questões sociais, econômicas e políticas de um país de um modo criativo para escamotear os censores. É o caso de O Bem Amado (Globo, 1973), escrita por Dias Gomes. Essa obra foi a primeira telenovela brasileira transmitida em cores e também a primeira a ser exportada abrindo espaço para as produções nacionais no exterior porque, anteriormente, apenas os roteiros eram comercializados. O Bem Amado conta a história de Odorico Paraguaçu, interpretado por Paulo Gracindo, prefeito corrupto e demagogo da cidade fictícia de Sucupira, localizada hipoteticamente no litoral baiano. O maior objetivo de sua administração é a construção de um cemitério. Entretanto, após a realização deste empreendimento, ninguém morre na cidade impedindo sua inauguração. Essa obra fazia uma crítica, na forma de humor, aos políticos da época de um modo metafórico para que a censura não notasse. Mesmo assim, a censura federal, em julho de 1973, proibiu o uso da palavra coronel na novela porque os militares acreditavam que Dias Gomes se referia ao coronel de patente militar quando, na verdade, o autor fazia referência aos fazendeiros e políticos 
corruptos do sertão baiano. ${ }^{12}$ Nota-se nesta novela uma das principais tendências das novelas realistas: o retrato do país através de regiões distantes dos grandes centros urbanos, integrando o país como um grande território e diversidade cultural. Assim como Beto Rockfeller, O Bem Amado "foi uma das primeiras narrativas a buscar em coisas genuinamente brasileiras seus entrechos". (Fernandes, 1994, p. 167)

Desde Irmãos Coragem (TV Globo, 1970) ${ }^{13}$, de autoria de Janete Clair, a novela passou a conquistar o público masculino e infantil em um formato consagrado até aquele momento como sendo de um público feminino.

Janete Clair arrebatou pela primeira vez o Brasil, com esta novela que misturava garimpo, futebol e política, em meio aos habituais amores impossíveis de suas tramas. Irmãos Coragem conquistou a definitiva adesão do público masculino às telenovelas. (Ferreira ,2003, p. 52)

Irmãos Coragem estreou no dia 21 de junho de 1970, na mesma época em que o Brasil comemorava o título de tricampeão mundial de futebol. Na ficção, Irmãos Coragem enfocava a história de Duda, um dos irmãos Coragem com promissora carreira de jogador de futebol do Flamengo. Ambientada em Coroado, cidade fictícia do interior de Goiás, a novela retrata o tema rural, bastante presente nas novelas realistas. Numa mistura de western e futebol, a novela conta a história de três irmãos - João (Tarcísio Meira), Duda (Cláudio Marzo) e Jerônimo (Cláudio Cavalcanti) - que se unem para combater a injustiça que recai sobre o irmão mais velho João, quando este tem seu diamante, achado no garimpo, roubado. "Irmãos Coragem deu mais audiência que o final da Copa, entre Brasil e Itália. O jogo foi num domingo e, no dia seguinte, a audiência da novela foi maior" afirma Daniel Filho apud (Ferreira, 2003, p. 56).

Irmãos Coragem teve mesmo ares audaciosos, Exibida em tempos de ditadura, quando presos políticos eram torturados e mortos nos porões do regime militar, Irmãos Coragem mostrou sintonia com a realidade política do país ao apresentar na fictícia Coroado eleições, política e justiça controladas e corrompidas pelas elites latifundiárias. (Ferreira, 2003, p. 54)

Não só o futebol foi retratado nas novelas dessa época. O automobilismo, por exemplo, era o tema central da novela das 20h Véu de Noiva (Globo, 1969-1970), de autoria

12 . Ver: http://memoriaglobo.globo.com ,acessado em 03/10/2009.

13 . Irmãos Coragem foi regravada em 1995 para o horário das 18 horas. Entretanto, sem o mesmo sucesso arrebatador da primeira versão de 1970. 
de Janete Clair e divulgada nos meios publicitários da época. Em Véu de Noiva, tudo acontece como na vida real, reforçando um dos objetivos centrais das novelas realistas, aproximando o formato de uma realidade do país. Cláudio Marzo interpretava um piloto à semelhança de Emerson Fittipaldi, principal piloto brasileiro da época. Já a novela das dez trazia temas da atualidade como o desquite e a reforma agrária em Verão Vermelho (Globo 1970), de Dias Gomes. Véu de Noiva foi readaptada pelo SBT em 2009 com o título Vende-se um véu de noiva, por Iris Abravanel, a fim de mais uma vez de reativar o setor de teledramaturgia da emissora.

Pode-se observar que nas novelas realistas, além do retrato do mundo rural, há uma forte preocupação em reproduzir os problemas das grandes metrópoles que, entre outras questões, foram crescendo desordenadamente, atraindo um número cada vez maior de migrantes do interior para os grandes centros urbanos. Desse modo, verifica-se nesse período uma "intensa migração do campo para a cidades (já em 1970, a população urbana superou a do campo), a industrialização e a proletarização do trabalho no campo, o desenvolvimento de um amplo mercado de consumo" (Lopes, 2003: 20) . Tal temática do Brasil foi retratada em diversas obras. Em Selva de Pedra (Globo, 1972), de autoria de Janete Clair, Cristiano Vilhena, interpretado por Francisco Cuoco, vive em Campos, interior do Rio de Janeiro, sem muitas perspectivas de crescimento pessoal e profissional. Ambicioso, ele acaba por trabalhar no estaleiro de um tio rico e logo transforma-se no diretor deste grande empreendimento. Em Vale Tudo (Globo, 1988), Gilberto Braga cria a história de Maria de Fátima (Glória Pires), uma jovem ambiciosa capaz de tudo para subir na vida. Ela sonha em ser modelo e, após vender a casa de sua mãe Raquel (Regina Duarte), foge com o dinheiro de Foz do Iguaçu, no interior do Paraná, para o Rio de Janeiro. Raquel vai atrás da filha, que a ignora solenemente. Uma das cenas mais antológicas de Vale Tudo é quando Maria de Fátima, após se casar com Afonso (Cassio Gabus Mendes), neto da milionária Odete Roithman (Beatriz Segall), está tomando sol na praia e avista sua mãe vendendo sanduíche na praia para sobreviver. Ela acena para a mãe como se fosse uma vendedora qualquer, pede um sanduíche e ainda a humilha, dizendo que ela poderia ficar com o troco. A trama retratava a desonestidade, a ética e a corrupção e buscava discutir a seguinte pergunta: vale a pena ser honesto no Brasil? A trilha sonora da abertura, Brasil, composta por Cazuza e cantada por Gal Costa, reforçava a ideia central da trama: Brasil mostra a tua cara, quero ver quem paga pra gente ficar assim.... Vale tudo foi a primeira telenovela a retratar abertamente a homossexualidade feminina e fez 
merchandising social acerca do alcoolismo através da personagem Helena Roithman (Renata Sorrah). Nota-se que o merchandising social esteve muito presente nas novelas de realistas, mas ganharia força total na fase seguinte: nas novelas naturalistas, a partir de década de 1990.

As novelas realistas consolidaram umas das características presentes até hoje no formato: o de influenciar a moda, o costume e o comportamento. Ainda na década de 1970, uma produção mostrou claramente a força da novela nessas questões. Trata-se de Dancin Days (Globo, 1978), escrita por Gilberto Braga. A difícil readaptação de uma ex-presidiária na sociedade, temática principal da trama, foi sugerida por Janete Clair quando esta assistia a uma reportagem sobre o assunto no Globo Repórter. Aliás, característica marcante da novelista, que imprimia nas teclas da máquina de datilografar temáticas e discussões muito à frente de seu tempo, plantando o germe de uma combinação entre o jornalismo e a ficção, que constituiria marca registrada no gênero nas fases seguintes: novelas naturalistas (anos 90) e novelas híbridas (a partir de 2001). A história tem como protagonistas Julia Mattos (Sonia Braga), acusada de atropelar e matar um guarda- noturno, e sua irmã Yolanda Pratini (Joana Fomm). A rivalidade entre as irmãs e a luta de Júlia para reconquistar a filha após sair da prisão são dois assuntos que forneceram fôlego para os 174 capítulos da trama. A virada na vida de Júlia se dá quando ela se casa com o milionário Ubirajara (Ary Fontoura). Após um tempo fora do Brasil, os dois retornam. A cena que marca a profunda transformação da personagem é quando ela vai à inauguração da discoteca Frenetic Dancin `Days e demonstra sua habilidade como dançarina, deixando todos impressionados. Tal cena foi claramente inspirada no filme Os Embalos de Sábado à Noite, com John Travolta, grande sucesso entre a juventude da década de 1970. Da noite para dia, centenas de discotecas foram abertas no país e até mesmo nos locais mais remotos do Brasil. A novela foi tema da revista norte-americana News Week, em novembro de 1978, que enfocava na reportagem a influência das novelas nos hábitos de consumo dos telespectadores, como o sucesso das meias coloridas Lurex, muito utilizadas por Sônia Braga na novela, que, além de lançar modismos, acabou promovendo alguns produtos como água de colônia, sandálias de salto fino e a boneca Pepa, companheira da personagem Carminha - a fábrica chegou a vender 400 mil unidades do brinquedo. ${ }^{14}$

Em 1985 a TV Globo produziu um dos maiores clássicos da telenovela brasileira: Roque Santeiro, escrita por Dias Gomes e Aguinaldo Silva. Uma primeira versão dessa obra havia sido gravada em 1975, mas a censura federal impediu a exibição deste título quando 35

14 . Segundo dados do site memoriaglobo.globo.com acessado em 13/10/2009. 
capítulos já haviam sido gravados. Tudo porque os censores se deram conta de que Roque Santeiro era uma adaptação do texto teatral O Berço do Herói, de autoria de Dias Gomes e anteriormente censurado. Observa-se que a censura parcial ou integral das telenovelas foi uma constante nas novelas realistas, visto que são obras escritas e produzidas durante o regime de ditadura militar, no qual a produção cultural sofreu uma forte intervenção do Estado que, como dissemos, investiu em tecnologias de transmissão de televisão e em políticas de integração nacional, com um forte controle de produção e de conteúdo respaldado pela censura Federal.

Além de Roque Santeiro e O Bem Amado, escritas por Dias Gomes, principal novelista do horário das dez da época, Janete Clair, responsável por 10 (63\%) das 16 novelas produzidas para o horário das 20 horas na década de 1970, também sofreu forte interferência do regime autoritário em suas obras, dentre as quais destacam-se Selva de Pedra (Globo, 1972), em que a censura federal proibiu que o personagem Cristiano Vilhena (Francisco Cuoco) se casasse com Fernanda (Dina Sfat) depois que sua mulher Simone (Regina Duarte) fosse dada como morta, entendendo que a personagem continuava viva, acabando por configurar crime de bigamia; Duas Vidas (Globo, 1976), em que Janete Clair tinha como objetivo retratar os transtornos que uma obra pública como a construção do metrô na cidade do Rio de Janeiro poderia causar aos moradores, o que desagradou o então presidente Ernesto Geisel, avalizador do projeto, segundo Ferreira (2003). Mas foi em Fogo Sobre Terra (Globo, 1974), que a novelista sofreu mais intervenção dos censores federais, tendo que inutilizar 12 capítulos de uma só vez porque a censura entendeu que a trama era uma crítica ao regime militar por fazer alusão à construção da usina hidrelétrica de Itaipu, uma das principais obras do governo federal na ocasião. Na trama, o personagem Pedro Azulão (Juca de Oliveira) era o líder de uma manifestação contra a construção de uma usina hidrelétrica que faria submergir a cidade fictícia de Divineia.

Quando o personagem incentivou o povo da cidade a pegar em armas e defender suas casas, os censores entenderam que Janete defendia táticas de guerrilha urbana. E lá foi Pedro para a prisão, acusado de desordem social, para que os telespectadores tivessem a lição de moral pretendida pela censura. (Ferreira, 2003, p. 83)

Notamos que a maioria destas obras desse período, quando não localizam a trama nos grandes centros urbanos como Rio de Janeiro ou São Paulo, retrataram outras localidades do país através da criação de cidades fictícias. Lançamos aqui uma hipótese que foge dos limites 
e objetivos dessa investigação: a de que esta estratégia - de retratar o interior do Brasil - serviu de instrumento para que os autores pudessem mostrar de maneira metafórica as mazelas políticas e sociais do país ajudando, assim, a escamotear os censores. Observando a tabela 1, é possível constatar que dos 50 títulos, 15 (30\%) ambientaram as tramas fora dos grandes centros urbanos tradicionais: Rio de Janeiro e São Paulo que somam 35 novelas (70\%). Em 13, dos 15 títulos que representaram o interior do país, foram criadas cidades fictícias, tais como: Coroado, Porto Azul, Vila da Prata, Sucupira, Divinéia, Rio Pardo, Bole-Bole, Sapucaí, Paço Alegre, Pilar ,Asa Branca, , Ouro Verde, Tangará e Santana do Agreste. Dos 15 títulos , apenas dois não foram ambientados em cidades fictícias : Verão Vermelho (1969) em Salvador-Bahia e Gabriela (1975) em Ilhéus.

Tabela 1: Novelas Realistas- TV Globo - (1969-1989)

\begin{tabular}{|c|c|c|c|c|c|c|c|}
\hline & Título & $\begin{array}{l}\text { horá } \\
\text { rio }\end{array}$ & ano & autor & $\begin{array}{l}\text { Cidade } \\
\text { urbana }\end{array}$ & $\begin{array}{l}\text { Cidade } \\
\text { fictícia/Suposta } \\
\text { localização }\end{array}$ & tempo \\
\hline 1 & Véu de Noiva & $20 \mathrm{~h}$ & 1969 & Janete Clair & $\begin{array}{l}\text { Rio de } \\
\text { Janeiro }\end{array}$ & $* * * * * * * * * *$ & Atual \\
\hline 2 & $\begin{array}{l}\text { Verão } \\
\text { Vermelho }\end{array}$ & $22 \mathrm{~h}$ & 1969 & Dias Gomes & $\begin{array}{l}\text { Salvador/ } \\
\text { Bahia }\end{array}$ & $* * * * * * * * * *$ & Atual \\
\hline 3 & $\begin{array}{l}\text { Irmãos } \\
\text { Coragem }\end{array}$ & $20 \mathrm{~h}$ & 1970 & Janete Clair & & $\begin{array}{l}\text { Coroado/Interi } \\
\text { or de Goiás }\end{array}$ & Atual \\
\hline 4 & $\begin{array}{l}\text { Assim na terra } \\
\text { como no Céu }\end{array}$ & $22 \mathrm{~h}$ & 1970 & Dias Gomes & $\begin{array}{l}\text { Rio de } \\
\text { Janeiro }\end{array}$ & $* * * * * * * * * *$ & Atual \\
\hline 5 & O Cafona & $22 \mathrm{~h}$ & 1971 & Bráulio Pedroso & $\begin{array}{l}\text { Rio de } \\
\text { Janeiro }\end{array}$ & $* * * * * * * * * *$ & Atual \\
\hline 6 & $\begin{array}{l}\text { O Homem } \\
\text { que deve } \\
\text { Morrer }\end{array}$ & $20 \mathrm{~h}$ & 1971 & Janete Clair & & $\begin{array}{l}\text { Porto } \\
\text { Azul/Interior } \\
\text { de Santa } \\
\text { Catarina } \\
\end{array}$ & Atual \\
\hline 7 & Bandeira 2 & $22 \mathrm{~h}$ & 1971 & Dias Gomes & $\begin{array}{l}\text { Rio de } \\
\text { Janeiro }\end{array}$ & $* * * * * * * * * *$ & Atual \\
\hline 8 & $\begin{array}{l}\text { Selva de } \\
\text { Pedra }\end{array}$ & $20 \mathrm{~h}$ & 1972 & Janete Clair & $\begin{array}{l}\text { Rio de } \\
\text { Janeiro }\end{array}$ & ************ & Atual \\
\hline 9 & O Bofe & $22 \mathrm{~h}$ & 1972 & $\begin{array}{l}\text { Bráulio Pedroso } \\
\text { e Lauro César } \\
\text { Muniz }\end{array}$ & $\begin{array}{l}\text { Rio de } \\
\text { Janeiro }\end{array}$ & $* * * * * * * * * *$ & Atual \\
\hline 10 & $\begin{array}{l}\text { Cavalo de } \\
\text { Aço }\end{array}$ & $20 \mathrm{~h}$ & 1972 & Walter Negrão & & $\begin{array}{l}\text { Vila da } \\
\text { Prata/Interior } \\
\text { do Paraná }\end{array}$ & Atual \\
\hline
\end{tabular}




\begin{tabular}{|c|c|c|c|c|c|c|c|}
\hline & Título & $\begin{array}{l}\text { Horá } \\
\text {-rio }\end{array}$ & Ano & Autor & $\begin{array}{l}\text { Cidade } \\
\text { urbana }\end{array}$ & $\begin{array}{l}\text { Cidade } \\
\text { fictícia/Suposta } \\
\text { localização }\end{array}$ & Tempo \\
\hline 11 & $\begin{array}{l}\text { O Bem } \\
\text { Amado }\end{array}$ & $22 \mathrm{~h}$ & 1973 & Dias Gomes & & $\begin{array}{l}\text { Sucupira/Litora } \\
1 \text { baiano }\end{array}$ & Atual \\
\hline 12 & O Semideus $^{15}$ & $20 \mathrm{~h}$ & 1973 & Janete Clair & $\begin{array}{l}\text { Rio de } \\
\text { Janeiro }\end{array}$ & *********** & Atual \\
\hline 13 & $\begin{array}{l}\text { Os Ossos do } \\
\text { Barão }\end{array}$ & $22 \mathrm{~h}$ & 1973 & Jorge Andrade & São Paulo & $* * * * * * * * * *$ & $\begin{array}{l}\text { Época } \\
(1930)\end{array}$ \\
\hline 14 & O Espigão & $22 \mathrm{~h}$ & 1974 & Dias Gomes & $\begin{array}{l}\text { Rio de } \\
\text { Janeiro }\end{array}$ & $* * * * * * * * * *$ & Atual \\
\hline 15 & $\begin{array}{l}\text { Fogo sobre } \\
\text { terra }\end{array}$ & $20 \mathrm{~h}$ & 1974 & Janete Clair & & $\begin{array}{l}\text { Divinéia/Sertão } \\
\text { de Mato } \\
\text { Grosso }\end{array}$ & Atual \\
\hline 16 & O Rebu & $22 \mathrm{~h}$ & 1974 & Bráulio Pedroso & $\begin{array}{l}\text { Rio de } \\
\text { Janeiro }\end{array}$ & $* * * * * * * * * *$ & Atual \\
\hline 17 & Escalada & $20 \mathrm{~h}$ & 1975 & $\begin{array}{l}\text { Lauro César } \\
\text { Muniz }\end{array}$ & & $\begin{array}{l}\text { Rio } \\
\text { Pardo/Interior } \\
\text { de São Paulo }\end{array}$ & $\begin{array}{l}\text { Época } \\
\text { Fase 1: } \\
1940 \\
\text { Fase 2: } \\
1956\end{array}$ \\
\hline 18 & Gabriela & $22 \mathrm{~h}$ & 1975 & $\begin{array}{l}\text { Walter George } \\
\text { Durst }\end{array}$ & $\begin{array}{l}\text { Ihéus- } \\
\text { Bahia }\end{array}$ & $* * * * * * * * *$ & Atual \\
\hline 19 & O Grito & $22 \mathrm{~h}$ & 1975 & Jorge Andrade & São Paulo & $* * * * * * * * * *$ & Atual \\
\hline 20 & $\begin{array}{l}\text { Pecado } \\
\text { Capital - 1 } \\
\text { versão }\end{array}$ & $20 \mathrm{~h}$ & 1975 & Janete Clair & $\begin{array}{l}\text { Rio de } \\
\text { Janeiro }\end{array}$ & ************ & Atual \\
\hline 21 & Saramandaia & $22 \mathrm{~h}$ & 1976 & Dias Gomes & & $\begin{array}{l}\text { Bole- } \\
\text { Bole/Vilarejo } \\
\text { Baiano }\end{array}$ & Atual \\
\hline
\end{tabular}

15 . Fato raro nas novelas de realistas, $O$ Semideus, com direção de Daniel Filho, teve gravações no exterior. Uma equipe foi deslocada para Portugal para gravar cenas em locais como Torre de Belém, Estoril e Convento de São Jerônimo, entre outros e Pecado Rasgado (Globo, 1978), novelas das 19 horas, de Sílvio de Abreu teve suas primeiras cenas gravadas em Paris. Entretanto, esse recurso parece ter sido um germe que se generalizou no período seguinte das novelas naturalistas. 


\begin{tabular}{|c|c|c|c|c|c|c|c|}
\hline & Título & $\begin{array}{l}\text { Horá } \\
\text {-rio }\end{array}$ & Ano & Autor & $\begin{array}{l}\text { Cidade } \\
\text { urbana }\end{array}$ & $\begin{array}{l}\text { Cidade } \\
\text { fictícia/Suposta } \\
\text { localização }\end{array}$ & Tempo \\
\hline 22 & O Casarão & $20 \mathrm{~h}$ & 1976 & $\begin{array}{l}\text { Lauro César } \\
\text { Muniz }\end{array}$ & & $\begin{array}{l}\text { Sapucaí/Norte } \\
\text { de São Paulo }\end{array}$ & $\begin{array}{l}\text { Época/ } \\
\text { Atual } \\
\text { fase 1: } \\
(1900 \text { a } \\
1910) \\
\text { fase 2: } \\
(1926 \text { a } \\
1936) \\
\text { fase 3: } \\
1976\end{array}$ \\
\hline 23 & Duas Vidas & $20 \mathrm{~h}$ & 1976 & Janete Clair & $\begin{array}{l}\text { Rio de } \\
\text { Janeiro }\end{array}$ & $* * * * * * * * * *$ & Atual \\
\hline 24 & $\begin{array}{l}\text { Espelho } \\
\text { Mágico }\end{array}$ & $20 \mathrm{~h}$ & 1977 & $\begin{array}{l}\text { Lauro César } \\
\text { Muniz }\end{array}$ & $\begin{array}{l}\text { Rio de } \\
\text { Janeiro }\end{array}$ & $* * * * * * * * * *$ & Atual \\
\hline 25 & Nina & $22 \mathrm{~h}$ & 1977 & $\begin{array}{l}\text { Walter George } \\
\text { Durst }\end{array}$ & São Paulo & $* * * * * * * * * *$ & $\begin{array}{l}\text { Época } \\
(1926 \text { a } \\
1929)\end{array}$ \\
\hline 26 & O Astro & $20 \mathrm{~h}$ & 1977 & Janete Clair & $\begin{array}{l}\text { Rio de } \\
\text { Janeiro }\end{array}$ & $* * * * * * * * * *$ & Atual \\
\hline 27 & $\begin{array}{l}\text { O Pulo do } \\
\text { Gato }\end{array}$ & $22 \mathrm{~h}$ & 1978 & Bráulio Pedroso & $\begin{array}{l}\text { Rio de } \\
\text { Janeiro }\end{array}$ & $* * * * * * * * * *$ & Atual \\
\hline 28 & Dancing`Days & $20 \mathrm{~h}$ & 1978 & Gilberto Braga & $\begin{array}{l}\text { Rio de } \\
\text { Janeiro }\end{array}$ & $* * * * * * * * * *$ & Atual \\
\hline 29 & $\begin{array}{l}\text { Sinal de } \\
\text { Alerta }\end{array}$ & $22 \mathrm{~h}$ & 1978 & Dias Gomes & $\begin{array}{l}\text { Rio de } \\
\text { Janeiro }\end{array}$ & $* * * * * * * * * *$ & Atual \\
\hline 30 & Pai Herói & $20 \mathrm{~h}$ & 1979 & Janete Clair & & Paço Alegre & Atual \\
\hline 31 & Os Gigantes & $20 \mathrm{~h}$ & 1979 & $\begin{array}{l}\text { Lauro César } \\
\text { Muniz }\end{array}$ & & Pilar & Atual \\
\hline 32 & Água Viva & $20 \mathrm{~h}$ & 1980 & $\begin{array}{l}\text { Gilberto Braga } \\
\text { e Manoel } \\
\text { Carlos }\end{array}$ & $\begin{array}{l}\text { Rio de } \\
\text { Janeiro }\end{array}$ & *********** & Atual \\
\hline 33 & $\begin{array}{l}\text { Coração* } \\
\text { Alado }\end{array}$ & $20 \mathrm{~h}$ & 1980 & Janete Clair & $\begin{array}{l}\text { Rio de } \\
\text { Janeiro }\end{array}$ & $* * * * * * * * * *$ & Atual \\
\hline 34 & Baila Comigo & $20 \mathrm{~h}$ & 1981 & Manoel Carlos & $\begin{array}{l}\text { Rio de } \\
\text { Janeiro }\end{array}$ & $* * * * * * * * * *$ & Atual \\
\hline 35 & Brilhante & $20 \mathrm{~h}$ & 1981 & Gilberto Braga & $\begin{array}{l}\text { Rio de } \\
\text { Janeiro }\end{array}$ & $* * * * * * * * * *$ & Atual \\
\hline
\end{tabular}




\begin{tabular}{|c|c|c|c|c|c|c|c|}
\hline & Título & $\begin{array}{l}\text { Horá } \\
\text {-rio }\end{array}$ & Ano & Autor & $\begin{array}{l}\text { Cidade } \\
\text { urbana }\end{array}$ & $\begin{array}{l}\text { Cidade } \\
\text { fictícia/Suposta } \\
\text { localização }\end{array}$ & Tempo \\
\hline 36 & $\begin{array}{l}\text { Sétimo } \\
\text { Sentido }\end{array}$ & $20 \mathrm{~h}$ & 1981 & Janete Clair & $\begin{array}{l}\text { Rio de } \\
\text { Janeiro }\end{array}$ & $* * * * * * * * * *$ & Atual \\
\hline 37 & Sol de Verão & $20 \mathrm{~h}$ & 1982 & Manoel Carlos & $\begin{array}{l}\text { Rio de } \\
\text { Janeiro }\end{array}$ & $* * * * * * * * * *$ & Atual \\
\hline 38 & Louco Amor & $20 \mathrm{~h}$ & 1983 & Gilberto Braga & $\begin{array}{l}\text { Rio de } \\
\text { Janeiro }\end{array}$ & $* * * * * * * * * *$ & Atual \\
\hline 39 & Eu Prometo & $22 \mathrm{~h}$ & 1983 & Janete Clair & $\begin{array}{l}\text { Rio de } \\
\text { Janeiro }\end{array}$ & $* * * * * * * * * *$ & Atual \\
\hline 40 & Champagne & $20 \mathrm{~h}$ & 1983 & $\begin{array}{l}\text { Cassiano Gabus } \\
\text { Mendes }\end{array}$ & $\begin{array}{l}\text { Rio de } \\
\text { Janeiro }\end{array}$ & $* * * * * * * * * *$ & Atual \\
\hline 41 & Partido Alto & $20 \mathrm{~h}$ & 1984 & $\begin{array}{l}\text { Glória Perez e } \\
\text { Aguinaldo } \\
\text { Silva }\end{array}$ & $\begin{array}{l}\text { Rio de } \\
\text { Janeiro }\end{array}$ & $* * * * * * * * * *$ & Atual \\
\hline 42 & $\begin{array}{l}\text { Corpo a } \\
\text { Corpo }\end{array}$ & $20 \mathrm{~h}$ & 1984 & Gilberto Braga & $\begin{array}{l}\text { Rio de } \\
\text { Janeiro }\end{array}$ & $* * * * * * * * * *$ & Atual \\
\hline 43 & $\begin{array}{l}\text { Roque } \\
\text { Santeiro }\end{array}$ & $20 \mathrm{~h}$ & 1985 & Dias Gomes & & Asa Branca & Atual \\
\hline 44 & $\begin{array}{l}\text { Selva de } \\
\text { Pedra - } \\
\text { remake }\end{array}$ & $20 \mathrm{~h}$ & 1986 & Janete Clair & $\begin{array}{l}\text { Rio de } \\
\text { Janeiro }\end{array}$ & $* * * * * * * * * *$ & Atual \\
\hline 45 & Roda de Fogo & $20 \mathrm{~h}$ & 1986 & $\begin{array}{l}\text { Lauro César } \\
\text { Muniz }\end{array}$ & $\begin{array}{l}\text { Rio de } \\
\text { Janeiro }\end{array}$ & $* * * * * * * * * *$ & Atual \\
\hline 46 & O Outro & $20 \mathrm{~h}$ & 1987 & $\begin{array}{l}\text { Aguinaldo } \\
\text { Silva }\end{array}$ & $\begin{array}{l}\text { Rio de } \\
\text { Janeiro }\end{array}$ & $* * * * * * * * * *$ & Atual \\
\hline 47 & Mandala & $20 \mathrm{~h}$ & 1987 & Dias Gomes & $\begin{array}{l}\text { Rio de } \\
\text { Janeiro }\end{array}$ & $* * * * * * * * * *$ & Atual \\
\hline 48 & Vale Tudo & $20 \mathrm{~h}$ & 1988 & Gilberto Braga & $\begin{array}{l}\text { Rio de } \\
\text { Janeiro }\end{array}$ & $* * * * * * * * * *$ & Atual \\
\hline 49 & $\begin{array}{l}\text { O Salvador da } \\
\text { Pátria }\end{array}$ & $20 \mathrm{~h}$ & 1989 & $\begin{array}{l}\text { Lauro César } \\
\text { Muniz }\end{array}$ & & $\begin{array}{l}\text { Ouro } \\
\text { Verde/Tangará }\end{array}$ & Atual \\
\hline 50 & Tieta & $20 \mathrm{~h}$ & 1989 & $\begin{array}{l}\text { Aguinaldo } \\
\text { Silva }\end{array}$ & & $\begin{array}{l}\text { Santana do } \\
\text { Agreste }\end{array}$ & Atual \\
\hline
\end{tabular}

Roque Santeiro foi ambientada na fictícia Asa Branca, cidade cenográfica criada para ser parecida com Juazeiro do Norte, no Ceará, Porto das Caixas, no Rio de Janeiro, e 
Aparecida do Norte, em São Paulo, cidades tradicionais do Brasil conhecidas por ter a maior fonte de renda dependente de questões religiosas. Aqui, a ideia de integração chega ao ápice na medida em que numa mesma localidade é possível identificar uma mistura de regiões do Brasil, distantes no espaço e nos costumes e uma convivência de sotaques distintos que carregam, pelo menos, uma característica em comum: o código da língua portuguesa, a oficial da nação. Em Asa Branca, misturou-se o colonial carioca com o nordestino, construções da região central com elementos do sul, tudo com o objetivo de representar em Asa Branca o país por inteiro. Os sotaques dos personagens seguiam essa mesma linha: nordestina (Sinhozinho Malta e Porcina), mineiro (seu Flô), gaúcho (o delegado) e carioca (Matilde, Ninon e Rosaly). ${ }^{16}$

Segundo Hambúrguer (2005, p. 85):

O foco das novelas da Globo na expressão `a vida como ela é' é coerente com o mote do Jornal Nacional, lançado pela emissora em 1969, ano da primeira novela contemporânea (Beto Rockfeller). Essa produção local fechou o mercado às concorrentes, tidas como de qualidade inferior, apelativas, feitas para fazer chorar. E contraste, o produto brasileiro incorporou o humor, a ironia, o sarcasmo; apresentou figurinos da moda e maior densidade nas tramas que assimilaram a crítica de costumes.

Dessa forma, as novelas realistas elegem as questões de identidade nacional, as temáticas do cotidiano como um fértil terreno criativo para suas tramas e propõem a telenovela brasileira como um espaço privilegiado de representação da nação.

\begin{abstract}
Não resta dúvida de que a novela constitui um exemplo de narrativa que ultrapassou a dimensão do lazer, que impregna a rotina cotidiana da nação, construiu mecanismos de interatividade e uma dialética entre o tempo vivido e o tempo narrado e que se configura como uma experiência ao mesmo tempo cultural, estética e social. Como experiência de sociabilidade, ela aciona mecanismos de conversação, de compartilhamento e de participação imaginária. A novela tornou-se uma forma de narrativa sobre a nação e um modo de participar dessa nação imaginada. (Lopes, 2003, p. 29)
\end{abstract}

É importante ressaltar que, na contramão das tendências de produção de novelas mais realistas no início da década de 1980, a recém criada TVS - (Tevê Estúdios Sílvio Santos) de São Paulo - que viria mais tarde a se tornar o SBT, produziu novelas com características explícitas das novelas sentimentais. Entre 1982 e 1985, o SBT produziu 15 novelas 
“dramalhões", a maior parte da escritora mexicana Marisa Garrido. (Ortiz, Borelli, Ortiz Ramos, 1989). Os títulos em si já trazem marcas do folhetim tradicional: Destino (SBT, 1982), A força do amor (SBT, 1982), Acorrentada (SBT, 1983) e A Justiça de Deus (SBT, 1983), entre outros. Vice-líder absoluto de audiência durante a década de 1980, o SBT nunca manteve a regularidade de produção do formato colaborando para a hegemonia da TV Globo que soube, desde sempre, aliar competência artística, técnica e administrativa, o que a tornou uma das empresas de televisão mais competitivas no mundo, conhecida, principalmente, pela produção de telenovelas.

Observando a tabela 1( p. 26) notamos a tendência das novelas do prime-time da TV Globo em situar suas tramas em grandes centros urbanos e periodizar a história em um tempo atual ou contemporâneo. Das 50 novelas da Globo, produzidas no período compreendido entre 1969 e 1989, 46 (92\%) são contemporâneas e apenas 4 (8\%) - Os Ossos do Barão (1973), Escalada (1975), O Casarão (1976) e Nina (1977) - são de época e nenhuma delas é histórica ou se propõe a retratar o "real" através de citações de períodos históricos. Embora a função de se retratar a história do Brasil está, tradicionalmente, a cargo das minisséries (Kornis, 2000), a exemplo de A Muralha (Globo, 2000) que conta a saga dos Bandeirantes que desbravaram territórios no interior do país em busca de riquezas, Os Maias (Globo, 2001), com a história da decadência da aristocracia portuguesa no século XIX, A Casa das Sete Mulheres (Globo, 2003) que aborda a revolução Farroupilha (1835-1845), JK (Globo, 2006), baseada na trajetória do Presidente Juscelino Kubitschek e Amazônia - de Galvez a Chico Mendes (Globo, 2007) com a história do Acre como último território a ser anexado ao Brasil e única região que se destacava na produção de borracha, as telenovelas também contemplam a história mais recente do país contextualizando, na ficção, momentos políticos e sociais e situam as tramas em momentos históricos importantes do país como a abolição da escravatura em Escrava Isaura (Globo, 1976), Sinhá Moça (Globo, 1986) e Pacto de Sangue (Globo, 1989).

\subsection{Novelas Naturalistas (1990-2001)}

Mantendo as características primeiras do gênero que lhe deu origem - o melodrama, com o objetivo de sempre ensinar algo, como as tradicionais lições de moral presentes no folhetim clássico que sempre punia o vilão e exaltava os heróis - a telenovela passou a 
incorporar uma ação pedagógica explícita (Lopes, 2009), sobretudo, no início dos anos 90, quando apresenta os temas sociais de maneira mais deliberada Em consequência, "nessa evolução histórica da matriz do melodrama persegue-se o efeito de verossimilhança a partir do aprofundamento do tratamento naturalista de temáticas sociais nas tramas, notadamente na década de 1990, superando a proposta realista dos anos 1970”, afirma Lopes (2009, p. 16)

Se, na fase anterior, a telenovela privilegiava temáticas que davam conta de comportamentos sociais, modas, a possibilidade de integração ao consumo possibilitado pelo milagre econômico e a modernização do Brasil através de uma "ação pedagógica implícita" (Lopes, 2009, p. 33), na fase seguinte ganham força as temáticas que estimulam a sociedade a debater assuntos políticos, econômicos, culturais e sociais do Brasil. É o que Esther Hamburguer (2005) chama de novelas de intervenção:

Ganham destaque então novelas que podem ser consideradas de intervenção, na medida em que se propõem a intervir diretamente em determinados assuntos pontuais, escolhidos pelos autores, de acordo com as afinidades de seus respectivos estilos. (Hamburger, 2005, p. 131)

As referidas intervenções fazem alusões ao mundo exterior à narrativa e se manifestam através de campanhas sociais escolhidas pelos autores. Convencionou-se chamar tais campanhas sociais promovidas pelas telenovelas de merchandising social ${ }^{17}$.

A inserção intencional e motivada por estímulos externos de questões sociais
nas tramas de telenovelas. Através do merchandising social, criam-se
oportunidades para interagir com as telenovelas, compondo momentos da
vida dos personagens e fazendo com que eles atuem como formadores de
opinião e/ou introdutores de inovações sociais. (Schiavo, 1995, p. 100)

Registre-se que o termo merchandising social só aparece oficialmente no site memoriaglobo.com - dedicado ao registro da memória das telenovelas produzidas pela TV Globo - em 1989, na novela O Salvador da Pátria, escrita por Lauro César Muniz, ocasião em que foi veiculada uma campanha sobre a Aids. Tal campanha manifestou-se através dos diálogos entre os personagens divulgando informações sobre o tratamento e combate ao preconceito. Segundo informações registradas nesse site, essa intervenção foi resultado de

17 Estudos acerca do merchandising social podem ser encontrados em Schiavo (1995), Trindade (1999), e Nicolosi (2009). 
uma parceria entre a TV Globo e do governo, representado pela divisão de Aids do Ministério da Saúde. A trama principal gira em torno de Sassá Mutema (Lima Duarte), um bóia-fria que chega a virar prefeito. Na sinopse original, Sassá deveria se transformar em presidente da república, mas o autor da trama mudou o destino do personagem, pressionado por grupos políticos que acreditavam que a novela serviria de propaganda gratuita de Luis Inácio Lula da Silva, candidato às eleições presidenciais de 1989. O Salvador da Pátria passa então a tratar do problema da rede de narcotráfico e alivia seu caráter político ${ }^{18}$. Na década de 90 , a extinta Rede Manchete de Televisão ameaçou a hegemonia da TV Globo investindo pesado no gênero contratando autores de peso da concorrente, como Glória Perez e Benedito Rui Barbosa. Glória Perez escreveu Carmen (Manchete, 1987) e Benedito Rui Barbosa, Pantanal (Manchete, 1990), um dos maiores sucessos da história da telenovela brasileira de todos os tempos. Em sintonia com as novelas naturalistas, Carmen também tratou do problema da Aids, enquanto Pantanal trouxe para a tela discussões da ecologia e apostando em um Brasil distante pouco conhecido pelos brasileiros: o pantanal mato-grossense. Pantanal foi gravada e exibida pela primeira vez em 1990, coincidindo com o Ano Internacional da Ecologia, tema que foi amplamente agendado pela mídia na época. Essa pode ser considerada uma das hipóteses de seu sucesso. Em verdade, na ocasião de sua reprise no SBT em 2008, o tema da ecologia também desperta muito interesse da mídia, só que dessa vez em proporções ainda mais amplas, considerando-se que cada vez mais as nações se unem em prol da consciência mundial sobre o assunto e da defesa do meio ambiente. Cabe enfatizar que a obra, dentre outras questões, tratou de um importante fato histórico, econômico e político do Brasil: o confisco das cadernetas de poupança pelo então presidente Fernando Collor, que remexeu com a vida e os sonhos dos brasileiros os quais, da noite para o dia, presenciaram desmoronar a possibilidade de aquisição de bens como a casa própria, o automóvel novo, enfim, dos ideais de pertencimento de uma vida urbana e capitalista. Em Barriga de Aluguel (Globo, 1990), Glória Perez discute as questões éticas envolvidas no processo científico de inseminação artificial. Quase no final da trama, uma discussão jurídica decidia o destino da criança nascida pelo método de barriga de aluguel - ela deveria ficar com a mãe biológica ou com a mãe que emprestou seu ventre para gerar o feto? Em O Dono do Mundo (Globo, 1991), de Gilberto Braga, o nome do personagem Beija Flor (Ângelo Antonio) foi claramente inspirado em Cazuza, cantor falecido vitimado pela Aids. Em muitas cenas, o personagem aparecia vestido

18 Fonte: Memória Globo, disponível em: http://memoriaglobo.globo.com/Memoriaglobo/0,27723,GYN05273-224168,00.html acessado em 21/10/2009. 
com a camiseta da sociedade Viva Cazuza e sua transformação de caráter na novela o tornou uma pessoa mais honesta, ao contrário do início da trama, quando era rebelde e se envolvia com marginais. Há registros de que a postura de Beija Flor na novela inspirou campanha em prol da ética na Sociedade Brasileira de Marketing naquele ano. Em De Corpo e Alma (Globo, 1992), novela de Glória Perez, o assunto sobre transplante de órgãos ganhou destaque através da personagem Paloma (Cristiana Oliveira), que recebeu o coração de Bettina (Bruna Lombardi), morta após sofrer um acidente de carro. A imensa fila de espera enfrentada por pacientes que necessitam de um órgão para sobreviver, os problemas entre as famílias de doadores e receptores foram os principais assuntos tratados. Segundo registros da TV Globo $^{19}$, somente na semana da estreia da novela, o Incor - Instituto do Coração de São Paulo - registrou nove órgãos de transplante. Nos dois meses anteriores, não houve nenhuma doação. No final do ano de 1992, o assassinato da atriz, Daniela Perez, filha da autora, abalou o país e a novela incluiu na pauta a questão da demora da justiça em julgar processos e a inadequação do código penal. Em Renascer (Globo, 1993), através dos personagens Teca (Paloma Duarte), Neno (Cassiano Carneiro) e Pitoco (Oberdan Júnior), Benedito Rui Barbosa mostra a dura vida dos moradores de rua, tema sugerido pela Unicef a autores de novelas. $\mathrm{Na}$ ocasião, participavam desse congresso Benedito Rui Barbosa e Glória Perez. Teca engravida de um menino de rua que morre na trama depois da chacina da Candelária, ocorrida no ano em que a trama era exibida. A novela discute ainda o tema de celibato clerical e da corrupção política. Padre Lívio (Jackson Costa) apaixona-se por uma das personagens da trama e promove discursos a favor da reforma agrária, questiona os governos militares e chega até a sugerir o fechamento do Congresso Nacional. Em Pátria Minha (Globo, 1994), de Gilberto Braga, o merchandising social ganhou destaque na trama através da Ação da Cidadania contra a miséria pela vida, campanha iniciada em 1993 pelo sociólogo Betinho. Em Explode Coração (Globo,1995), escrita por Glória Perez, cerca de 100 crianças desaparecidas foram reencontradas pela família após campanha feita pela novela. Enquanto na ficção a personagem Odaísa - interpretada por Isadora Ribeiro - procurava pelo filho desaparecido Gugú interpretado por Luiz Cláudio Júnior - mães da vida real divulgavam cartazes com as fotos dos filhos desaparecidos. Estas cenas eram gravadas em locação nas escadarias da igreja da Candelária na região do central do Rio de Janeiro, uma evidente referência à conhecida chacina da Candelária, ocorrida em 1992, na qual policiais militares assassinaram crianças de

19 memoriaglobo.globo.com acessado em 18/10/2009. 
rua.

Essa é a realidade, como no caso das crianças desaparecidas que a mãe da novela se sentava na escadaria e abria espaço para as mães reais fazerem seu apelo. Nós encontramos cem crianças; mais de cem crianças só durante a novela, fora o que foi encontrado depois, quando a campanha pegou. Se você faz esse tipo de campanha porque isso é muito perigoso, eu inventei de fazer isso na novela, mas eu acho perigoso. Você tem de estar dentro do limite, você não pode perder a mão em momento algum, e essas campanhas têm de estar absolutamente vinculadas à história que você esta contando, senão você para a história, faz uma propaganda, começa outro programa. Você não pode falar teoricamente, é muito chato e cai naquilo que é mais chato, que é o politicamente correto, que por si é insuportável e não combina com a televisão. Eu procuro sempre fazer histórias. Por exemplo, vamos pegar o exemplo que você pegou das mães dos desaparecidos, como isso foi abordado essa campanha? Na novela tinha uma personagem que o público gostava, estava acompanhando aquela história e o filho dela sumia, você está interessado. Mas eu tinha passado, eu, pessoa, na Cinelândia e vi uma cena horrorosa que as pessoas não prestavam a atenção, eram mulheres muito pobres segurando papeis menores do que este aqui assim, toda segunda-feira elas estavam lá, ninguém olhava para elas e esse apelo era para ver se alguém que passava e olhasse tivesse a sorte de ter visto aquela criança que ela estava procurando. Eu pensei, meu Deus, isso só depende de divulgação, se estas crianças não estão mortas alguém viu em algum lugar, né? Então vamos arrumar uma maneira de colocá-las na trama, que não é dizendo tantas crianças desaparecidas no país, que é um saco. Se você puser a personagem que perdeu um filho, que era pobre, aí ela passa todo o trajeto. Eu fui conversar com as mães e vi o que as mães passavam, chegar na delegacia, o delegado tá acompanhando - a criança tinha 4 anos - essas mães reais chegam na delegacia, eu tô falando da mãe real, mas na ficção foi igualzinho e diz que uma criança de 4 anos sumiu. Aí o delegado responde: "só pode ser dado como sumido diante da lei depois de $24 \mathrm{~h} / 48 \mathrm{~h}$ ". Depois desse tempo já levaram a criança, mataram, já fizeram qualquer coisa, não adianta mais procurar. Então a mãe ficava naquela angústia pavorosa sem ter o que fazer, e toda essa angústia batendo na porta dos jornais para ver se a imprensa fazia alguma coisa. Ela era mais uma sentada ali nas portas, pedindo para publicarem aquele retrato que ninguém publicava. Então a nossa mãe da novela vive essa angústia, vivia essas mesmas coisas, e quando ela abria espaço para mãe real, já estava tão dentro da emoção do público aquela história, porque aquela história tinha entrado a partir da história da novela, não era uma interrupção na novela para falar de um tema. ${ }^{20}$

Em 1996, Benedito Ruy Barbosa, através da novela $O$ Rei do gado (Globo, 1996), focalizou o Movimento dos Sem-Terra (MST). Na trama, um senador da ficção, Roberto Caxias - interpretado por Carlos Vereza - interagiu com elementos exteriores à narrativa, na medida em que trocava elogios e cumprimentos com um senador da vida real (Darcy Ribeiro),

\footnotetext{
${ }^{20}$ PEREZ, Glória. Palestra proferida no I Encontro Nacional Obitel em São Paulo, 28 nov. 2007.
} 
enquanto este elogiava o caráter íntegro do personagem por meio dos jornais, aquele agradecia e retribuía os elogios nos capítulos do folhetim. Um dos momentos de destaque desta relação do ficcional com o factual pode ser exemplificado quando da morte do senador da ficção, Roberto Caxias. Na ocasião do velório, dois políticos de destaque do país, Eduardo Suplicy e Benedita da Silva, participaram da cena interagindo com os atores da ficção. Com o uso de recursos próprios do documentário - olhar direto para a câmera como numa entrevista para noticiário de tevê - os ocupantes de cargo político apelaram pela reforma agrária e denunciaram a situação dos sem-terra. Essa estratégia de direção e edição visando efeitos de documentário ganhará força a partir de $O$ Clone (Globo, 2001), já nas novelas hibridas. Em a Indomada (Globo, 1997), escrita por Aguinaldo Silva e Ricardo Linhares, a personagem Grampola (Carla Muga) foge de uma casa de prostituição da trama, onde tinha sido supostamente vendida pela própria família e dá outro destino ao personagem. Com ela, a novela ganhou reconhecimento da Campanha Nacional pelo fim da exploração, da violência e do turismo sexual de crianças e adolescentes, problema que atinge principalmente o nordeste brasileiro. Em Por Amor, (Globo, 1997), Manoel Carlos põe em discussão o preconceito racial através da personagem negra Márcia (Maria Ceiça) casada com Wilson (Paulo César Grande), homem branco que não admitiu a possibilidade de ter um filho negro. Como a criança nasceu branca, a discussão social seguiu por outro caminho: o de as pessoas acharem que Márcia é babá e não mãe da criança. Em Laços de Família (Globo, 2000), Manoel Carlos consagra de vez seu estilo dramatúrgico na preferência em abordar temáticas sociais. Nessa obra, diversas campanhas de merchandising social podem ser destacadas. Além da principal, que abordou a questão do transplante de medula óssea como alternativa no tratamento da leucemia, a novela abordou a dificuldade de jovens com limitações motoras em vencer suas dificuldades. Inspirado no dilema do ator Flávio Silvino, vitimado de acidente de carro que deixou graves sequelas, Manoel Carlos criou o personagem Paulo, que foi interpretado pelo próprio Flávio Silvino. A novela abordou ainda o tema da impotência sexual masculina, retratando o dilema dos homens que sofrem dessa doença, esclarecendo possibilidades de tratamento.

Como se vê, o merchandising social está presente na maioria das novelas naturalistas, ou seja, a partir do início da década de 1990, o que nos permite apontar que essa forma de abordar questões sociais é o que categoriza predominantemente as novelas do período. Não se pense que o merchandising social deixou de existir nas novelas da fase seguinte, nas novelas 
híbridas dos anos 2000 em diante; pelo contrário, consolidou-se como marca do formato mas, talvez, com uma pontual diferença que passaremos a defender nesta investigação: as novelas híbridas trouxeram mais fortemente o real para a ficção, consolidando a telenovela brasileira como um formato genuinamente híbrido, que acaba por combinar elementos formais do documentário com a ficção. Nicolosi (2009) demonstra que só em Páginas da vida (Globo, 2006) houve 117 inserções de merchandising social, retratando assuntos como Aids, bulimia, alcoolismo, adoção e síndrome de down. Algumas inserções de merchandising social foram exibidas aos moldes de um documentário cinematográfico, que registrou a visita do médico Diogo (Marcos Paulo) ao continente africano. Para gravar essas cenas, o diretor Jayme Monjardim e Marcos Paulo viajaram acompanhados de voluntários da ONU para o Congo, Ruanda, Quênia e Barundi, As imagens foram gravadas em minidv, formato de vídeo com resolução bem inferior à qualidade profissional com que a novela foi gravada, certamente, para reforçar o efeito de documentário às cenas.

$\mathrm{Na}$ tabela a seguir, ilustramos como o merchandising social esteve presente nas novelas de maior audiência do ano de 2008, conforme dados levantados e tratados pelo Obitel Brasil:

Tabela 2: Merchandising social em Os 10 mais de $2008^{21}$

\begin{tabular}{|l|c|c|c|c|c|c|c|c|}
\hline Título & $\begin{array}{l}\text { Saúde e } \\
\text { qualidade } \\
\text { de vida }\end{array}$ & $\begin{array}{l}\text { Valores, } \\
\text { princípios } \\
\text { e relações } \\
\text { humanas }\end{array}$ & $\begin{array}{l}\text { Cidadania } \\
\text { e direitos }\end{array}$ & $\begin{array}{l}\text { Educação } \\
\text { ciência e } \\
\text { desenvol- } \\
\text { vimento } \\
\text { humano }\end{array}$ & $\begin{array}{l}\text { Desenvol- } \\
\text { vimento } \\
\text { e meio } \\
\text { ambiente }\end{array}$ & $\begin{array}{l}\text { Cultura e } \\
\text { identidade }\end{array}$ & $\begin{array}{l}\text { Sexua- } \\
\text { lidade } \\
\text { e } \\
\text { relações } \\
\text { afetivas }\end{array}$ & Total \\
\hline $\begin{array}{l}\text { Duas } \\
\text { Caras }\end{array}$ & 32 & 29 & 25 & 15 & 4 & 2 & 2 & 109 \\
\hline $\begin{array}{l}\text { A } \\
\text { Favorita }\end{array}$ & 13 & 38 & 19 & 10 & 1 & 10 & 2 & 93 \\
\hline
\end{tabular}

21 Segundo mapeamento realizado pelo Obitel Brasil - ver anuário Obitel (2009, p. 155) -os sete grupos temáticos de inserções de merchandising social abrange os seguintes indicadores: O grupo "saúde e qualidade de vida" (132 inserções) contempla cenas que incentivam hábitos de vida saudáveis, higiene e cuidados básicos em saúde, tratamento de doenças, dependência química, doação de sangue e de órgãos. O grupo "Valores, princípios e relações humanas" (119 inserções) compreende indicadores como corrupçao, atividades ilegais criminosas, preconceito e discriminação, solidariedade e ação social, entre outros. O grupo "cidadania e direitos" (57 inserções) abrange, entre outras questões, direitos das pessoas com deficiência, violência doméstica, direito do trabalho, direitos civis, políticos e econômicos. O grupo "Educação, ciência e desenvolvimento humano" (38 inserções) engloba cenas que tratam de educação no trânsito, valorização da educação, educação especial e inclusiva. O grupo "desenvolvimento e meio ambiente" (17 inserções) apresenta cenas que tratam da preservação da flora e da fauna, poluição, reciclagem, redução de lixo, desenvolvimento sustentável. O grupo temático "cultura e identidade" (12 inserções) apresentou cenas que focaram na valorização da cultura e das artes e o grupo "sexualidade e relações afetivas" (9 inserções) abrange cenas que tratam de temas como homossexualidade, gravidez não planejada, iniciação sexual. 


\begin{tabular}{|l|c|c|c|c|c|c|c|c|}
\hline Título & $\begin{array}{c}\text { Saúde e } \\
\text { qualidade } \\
\text { de vida }\end{array}$ & $\begin{array}{c}\text { Valores, } \\
\text { princípios } \\
\text { e relações } \\
\text { humanas }\end{array}$ & $\begin{array}{c}\text { Cidadania } \\
\text { e direitos }\end{array}$ & $\begin{array}{c}\text { Educação } \\
\text { ciência e } \\
\text { desenvol- } \\
\text { vimento } \\
\text { humano }\end{array}$ & $\begin{array}{c}\text { Desenvol- } \\
\text { vimento } \\
\text { e meio } \\
\text { ambiente }\end{array}$ & $\begin{array}{c}\text { Cultura e } \\
\text { identidade }\end{array}$ & $\begin{array}{c}\text { Sexua- } \\
\text { lidade } \\
\text { e } \\
\text { relações } \\
\text { afetivas }\end{array}$ & Total \\
\hline $\begin{array}{l}\text { Beleza } \\
\text { Pura }\end{array}$ & 19 & 28 & 11 & 7 & 3 & - & 1 & 69 \\
\hline $\begin{array}{l}\text { Três } \\
\text { Irmãs }\end{array}$ & 34 & 5 & - & 1 & 9 & - & 3 & 52 \\
\hline $\begin{array}{l}\text { Sete } \\
\text { Pecados }\end{array}$ & 24 & 9 & 1 & 5 & - & - & - & 39 \\
\hline $\begin{array}{l}\text { Desejo } \\
\text { Proibido }\end{array}$ & 10 & 10 & 1 & - & - & - & 1 & 22 \\
\hline Total & 132 & 119 & 57 & 38 & 17 & 12 & 9 & 384 \\
\hline
\end{tabular}

Fonte: TV Globo (categorização e tabulação)

De acordo com os dados da tabela, observa-se, que as novelas das 21 horas são as que mais inserem ações de merchandising social: Duas Caras, com 109 inserções ou 28\% do total e A Favorita, com 32 inserções, 24\%; seguidas pelas novelas da sete horas: Beleza Pura com 69 inserções ou 18\% do total, Três Irmãs com 52 inserções, 14\%; Sete Pecados com 39 inserções, $10 \%$ e ,por fim, a novela das seis, Desejo Proibido, com 22 inserções, 5,7\%.

É significativo que a telenovela brasileira, sem abandonar a estrutura do folhetim clássico, soube combinar em sua composição narrativa elementos tradicionais da ficção com a realidade, conforme observa Glória Perez:

E falo muito à vontade porque fui eu mesma que introduzi, pelo menos nas novelas aqui do Brasil, essa mistura da realidade com a ficção, mas eu fiz isso como? Eu comecei a observar, como eu disse para vocês, a ficção lá do século XIX, o folhetim do século XIX, e aí eu vi que hoje a gente olha para essas obras de Balzac que foram feitas para o folhetim e aí tem conde, parecem figuras tão fictícias, mas não eram figuras de um mundo à frente de um capitalismo, e eram tão fortes, tão reais, que Marx usou no Capital para dar exemplo de como funciona o capitalismo através de situações descritas em Balzac. Ele foi buscar no romance, no folhetim, a pintura destes tipos. Eu falei 'bom, é possível falar do cotidiano, da realidade, e ao mesmo tempo você estar contando uma história folhetinesca'. Junte-se a isso um país onde as instituições são frágeis, mas tão frágeis, que as pessoas esperam das novelas coisas que são destas instituições. ${ }^{22}$

22. PEREZ, Glória. Palestra proferida no I Encontro Nacional Obitel em São Paulo, 28 nov. 2007. 


\subsection{Novelas Híbridas. (2001 em diante)}

Um conceito chave que nos auxilia na compreensão do mundo contemporâneo é representado pelo hibridismo ${ }^{23}$, hibridização ou hibridação. Néstor Garcia Canclini (2003), em Culturas Híbridas, apresenta um profundo estudo e reflexão a respeito da convivência mútua entre o culto e o popular, a tradição e o moderno, em diversos aspectos da cultura. Garcia Canclini reconhece a complexidade deste conceito e suas insuficiências epistemológicas em edições anteriores de seu livro. Em razão disso, em uma edição atualizada, o autor nos esclarece o conceito de Híbridação: “entendo por hibridação processos socioculturais nos quais estruturas ou práticas discretas, que existiam de forma separada, se combinam para gerar novas estruturas, objetos e práticas”. (Garcia Canclini, 2003, p. XIX).

De outra parte, Burke ${ }^{24}$ (2003) alerta que todos os termos que fazem alusão ao hibridismo- mistura, fusão (física nuclear), sincretismo (história), ecótipo ${ }^{25}$ (botânica), entre tantos outros - devem ser manipulados com cuidado. Segundo o autor, há palavras demais que descrevem os mesmos fenômenos e o processo de interação cultural. Burke afirma que a expressão tradução cultural - usada pela primeira vez pela antropologia - é a mais útil e menos enganosa e descreve "o mecanismo por meio do qual encontros culturais produzem formas novas e híbridas”. (Burke, 2003, p. 55)

Na novela Caminho das Índias (Globo, 2009), Glória Perez escreveu duas cenas que ilustram bem esses encontros culturais de diferentes origens e tradições. Na Marquês de Sapucaí, legendário sambódromo do Rio Janeiro e conhecido mundialmente, a indiana Chanti (Carolina Oliveira) e a comitiva de atores/dançarinos de Bollywood dançam com mulatas de escola de samba, mestre sala, garis e com pessoas típicas cariocas. Ao som de uma música indiana, observam-se algumas notas musicais de samba ali misturadas. Paralelamente a essa performance dedicada à cultura indiana, com o consequente uso de roupas tradicionais da região que deixam mostrar muito pouco do corpo feminino, mulatas de escolas de samba

23. "Termo transplantado da biologia para as ciências sociais, hibridismo tornou-se, no final do século XX, bastante utilizado, devido, sobretudo, ao advento da globalização das sociedades, da mundialização da cultura, bem como as tecnologias de comunicação e informação. Esses fenômenos produziram um processo de troca cultural entre os povos de forma intensificada e até então inédita, unificando experiências e dispositivos heterogêneos". (Marcondes Filho, 2009, p. 160)

24 Ver BURKE, Peter. Hibridismo cultural. São Leopoldo: Unisinos, 2003.

25 Termo cunhado pela botânica e representa uma variedade de planta adaptada a um determinado ambiente pela seleção natural. (Burke, 2003, p. 53). 
dançam ao fundo com figurinos típicos do carnaval deixando o corpo seminu, como de costume no Brasil na ocasião dessa forma de manifestação popular. Assim como a telenovela, o carnaval é uma das principais manifestações da cultura brasileira e um dos exemplos clássicos de hibridização.

O desfile das escolas de samba do Rio de hoje segue a tradição dos cortejos e carros alegóricos da Florença e da Nuremberg do século XV. Mesmo as referências políticas tão comuns no carnaval brasileiro têm paralelos na Europa, por exemplo, na Espanha do século XVII. (Burke, 2003, p. 35)

Em outra cena, os indianos dançam em uma praia carioca e, em uma parte da performance indiana, surfistas fazem a mesma coreografia com suas pranchas, enquanto os demais frequentadores da praia se divertem e tentam arriscar passos da coreografia.

De um modo geral, nas telenovelas brasileiras contemporâneas é possível identificar elementos das novelas sentimentais (décadas de 1950 e 1960), realistas (décadas de 1970 e 1980) e naturalistas (década de 1990). Em Caminho das Índias, o plot inicial da trama tratava da história de amor impossível entre dois jovens de castas distintas. De um lado, Maya (Juliana Paes), de família tradicional indiana de casta, uma Brahmani, e de outro Bahuan (Marcio Garcia), um dalit (intocável), adotado por Shankar (Lima Duarte), profundo conhecedor das tradições indianas Os figurinos exóticos de uma cultura distinta em uma terra distante, os nomes estrangeiros Bahuan, Opash, Shankar, Laksmi e Raj, entre outros, lembram as histórias fantasiosas de uma outra Glória: a Magadán, uma das autoras centrais das novelas sentimentais que, sem dúvida, estimularam o telespectador a desenvolver mecanismos de recepção que funcionavam como uma espécie de pacto previamente estabelecido entre autor e espectador para tornar crível o inverossímil. Em Caminho das Índias, o fato de se falar o português corrente em plena Índia, misturado com expressões da língua local, Are Baba! (Meus Deus, não brinca!), Arebaguandi (Ai meu Deus!) Baguan Keliê (Por Deus!), é, sem dúvida, um mero detalhe que o espectador brasileiro, acostumado há décadas com hábito cotidiano de assistir a novelas, aceita sem maiores questionamentos. Apesar da aceitação do espectador, a emissora achou por bem a autora traduzir estas palavras toda que vez que fosse pronunciada, e Glória Perez criou um glossário em seu blog para ajudar os espectadores na tradução. Note-se que "as traduções são os casos mais óbvios de textos híbridos, já que a procura por aquilo que é chamado de efeito equivalente necessariamente envolve a produção de palavras e ideias que são familiares aos novos leitores” (Burke, 2003, p. 27). 
Glória Perez, ao colocar em evidência as diferenças culturais entre os indianos e os brasileiros, reforçava na novela as diferenças de identidade de cada uma das nações envolvidas. Afinal, o que é ser brasileiro e o que é ser indiano? Questões típicas das novelas realistas que buscavam retratar em suas tramas, entre outras questões, expressões coloquiais, gírias e o modo de ser e de se comportar do brasileiro. Através da personagem Camila (Ísis Valverde), a autora retratou, de uma maneira leve e suave, as dificuldades de uma brasileira de se adaptar aos costumes dos indianos. Camila casou-se com Ravi (Caio Blat) e teve que aprender a lidar com a nova cultura. Entre outras questões, ela não podia pronunciar o nome de seu marido em público. Por questão de respeito, deveria tratá-lo apenas como marido. Quando se encontrava em uma situação difícil por causa das diferenças, Camila sempre estava pronta para se desculpar, afirmando que no Brasil não era assim. Em outro momento, Maya (Juliana Paes) vai ao Rio de Janeiro e se espanta com a pouca roupa das cariocas e passeia em pleno dia de calor do Rio de Janeiro vestida com um tradicional sári.

Questões sociais também estiveram presentes em Caminho das Índias. Através do personagem Tarso (Bruno Gagliasso), a novela demonstrou o preconceito e as dificuldades que os portadores de esquizofrenia sofrem ao tentar conviver em sociedade. Um desfile da grife das doida ${ }^{26}$, com sede em São Paulo e idealizada por uma psiquiatra , foi ao ar em um dos capítulos da trama. Na novela, modelos da instituição e atores da novela desfilavam em um palanque improvisado na clínica psiquiátrica da ficção, estimulando a inclusão social e a integração dos portadores de doença mental com seus familiares e a sociedade. Em um outro núcleo, o personagem Zeca (Duda Nagle), um típico jovem de classe média alta, e sem nenhum limite imposto pelos país, cometeu as mais diversas atrocidades na trama cometendo atos de vandalismos e desrespeito ao professores. Nos capítulos finais da trama, ele atropela uma personagem grávida ocasionando a perda do bebê. A punição do personagem, por ser réu primário, foi branda e a justiça o obrigou a fazer trabalhos voluntários na sociedade Viva Cazuza. A presidente dessa instituição sugere que grande parte da culpa de os jovens se tornarem pessoas agressivas é dos pais, que não sabem impor limites aos filhos. Não se pode esquecer que em Caminho das Índias outra campanha social merece destaque: a educação no trânsito. O guarda de trânsito Abel (Anderson Muller) era severo no cumprimento às leis e abordava os pedestres que não respeitavam a faixa e atravessavam em qualquer local. Todas estas ações sociais são características das novelas naturalistas que manifestam ações sociais,

26 Das Doida é uma oficina experimental que faz pesquisas de imagens de moda em comunidades de serviço de saúde mental. 
exercendo uma função pedagógica explícita como vimos anteriormente.

Desde a sua origem, a telenovela já indicava sinais de hibridação, uma vez que o folhetim literário, umas das principais matrizes do gênero, era divulgado nos rodapés dos jornais, representando, assim, uma primeira combinação entre o jornalismo e a ficção. A esse respeito, Jesús Martin-Barbero (2003, p. 195) observa que “o folhetim é uma narração que já não é um conto, mas que tampouco chega a ser um romance. E uma escritura que não é literária nem jornalística, e sim a "confusão" das duas: a atualidade com a ficção". A fusão entre ideias, conceitos, estruturas e até mesmo de linguagem constitui marca registrada na telenovela. Nessa perspectiva, esta relação entre o factual e o ficcional, presente desde o estágio embrionário do formato, foi tornando-se cada vez mais evidente a ponto de tornar a telenovela um dos formatos mais híbridos da produção audiovisual contemporânea.

Como é óbvio, essa convivência com o real já existia na literatura e no cinema, nas biografias romanceadas e nos docudramas, entre outros; é, no entanto, na TV que as formas de convivência do real com o ficcional adquirem aspectos mais ambíguos, interferindo de forma clara nos modos de expressão ficcional, sobretudo no formato telenovela. (Balogh, 2002, p. 37)

Desde a década de 1970, a telenovela já apresentava em suas tramas um leque de temáticas factuais originadas, muitas vezes, nas notícias dos telejornais, uma espécie de crônica jornalística sob forma de representação ${ }^{27}$. Vale lembrar que a escritora Janete Clair já baseava suas tramas em notícias de jornais e até mesmo em classificados: a ideia da novela Véu de Noiva (Globo, 1969) surgiu quando a autora lia um anúncio de jornal cujo título era vende-se um véu de noiva. Método de trabalho adotado também por Glória Perez, sua seguidora, nas novelas naturalistas: Barriga de Aluguel (Globo, 1990) que retratou a polêmica de mães que alugam sua barriga para gerar filhos de outras mães com problemas para engravidar, De Corpo e Alma ( Globo, 1992), com a questão da doação de órgãos, e Explode Coração (Globo, 1995), que estampava fotografias de crianças desaparecidas no final da novela, auxiliando as mães nas buscas de seus filhos. Manoel Carlos afirma que a trama central de Laços de Família (Globo, 2000) foi inspirada em uma notícia de jornal dos

27 Em 26/04/2008, a novela Duas Caras, de Aguinaldo Silva, apresentou uma cena inspirada na tragédia do ônibus 174, ocorrida no Rio de Janeiro, na qual morreu o sequestrador Sandro Barbosa do Nascimento, que tinha feito como refém a professora Geísa Firmo Gonçalves. Na ficção, o personagem Ronildo (Rodrigo Hilbert) faz Solange (Sheren Menezes) como refém dentro de um ônibus e acaba morto. Em 2002, o diretor José Padilha filmou o documentário Ônibus 174, baseado em imagens de arquivo, documentos oficiais e entrevistas. 
Estados Unidos, em 1990, que mostrava uma mãe que engravida para salvar a vida da filha com leucemia. Com efeito, temas de grande repercussão da nação brasileira são reconstituídos ou simplesmente citados pela ficção televisual. A exemplo disso, Manoel Carlos, segundo artigo da revista Época publicada em 03 de março de $2003^{28}$, inseriu na novela Mulheres Apaixonadas, três horas antes de o folhetim ir ao ar, uma cena na qual as personagens de Suzana Vieira e Júlia Almeida, mãe e filha, dialogavam a respeito de um fato ocorrido na cidade do Rio de Janeiro naquele mesmo dia:

- Tem de tomar cuidado, filha. A situação não está brincadeira.

- Eu vi na televisão. Ontem incendiaram mais de 100 ônibus

- E hoje mais quatro! Jogaram bombas aqui do lado, na Avenida Vieira Souto! Ouvi dizer no rádio que Josias Quintal, secretário de segurança, vai pedir ajuda ao exército para combater a violência.

Beatriz Velloso, jornalista responsável pelo artigo, conclui a matéria dizendo que esta inserção dos fatos na ficção seguiu um ritmo de notícia de última hora, foi como se o jornal nacional tivesse invadido a novela. De fato, é possível encontrarmos notícias dos jornais enganchadas nos novelos ficcionais. Por outro lado, é possível observar um crescente interesse da imprensa escrita em discutir/divulgar a telenovela. Exemplo disso é um variado número de revistas especializadas Minha Novela, Contigo, entre outras e uma série de artigos dedicados à telenovela que são publicados diariamente em jornais de grande circulação, como Folha de São Paulo e Estado de São Paulo. Disso resulta a hipótese de que "a telenovela brasileira é tão vista quanto falada e seus significados são o produto tanto da narrativa audiovisual, produzida pela televisão, quanto da interminável narrativa oral produzida pelas pessoas“". (Lopes, 2003, p. 30)

De outra parte, Buonanno (1993, p. 179) observa que "just as television seemingly becomes ever more a highly 'newsworthy' subject for the press, equally news becomes ever more 'fictionworthy' for television". A propósito disso, analisamos empiricamente o programa Fantástico - jornal dominical da TV Globo - durante o mês de novembro de 2009 e constatamos o seguinte: das cinco edições exibidas nos dias 01, 08, 15, 22 e 29 de novembro de 2009, duas delas tiveram, como uma das principais pautas, assuntos sobre a telenovela Viver a Vida. Na edição do dia 08/11/09, o Fantástico abre o programa do dia com um

28 Ver: A novela faz jornalismo. Disponível em: http://revistaepoca.globo.com/Revista/Epoca/0,EMI3588915220,00-a+novela+faz+jornalismo.html. Acesso em: 05/02/2010. 
assunto pautado da telenovela e entrevista uma das pessoas que deram seu relato real no final de Viver a Vida:

Zeca Camargo (em off): Uma história surpreendente abre o Fantástico de hoje.

Patrícia Poeta (em off): Ela começa no dia em que este homem tentou sequestrar este empresário.

Zeca Camargo (em off): E o que aconteceu depois? Patrícia Poeta vai contar.

Patrícia Poeta (em off): No horário nobre da ficção, quem tem se destacado é a realidade... são caprichados roteiros da vida real.

"São depoimentos reais, não são forjados, não pertencem ao campo da ficção, então o público percebe e sente que todos aqueles casos de superação realmente aconteceram, são palpáveis, existem e então se comovem muito", afirma Manoel Carlos, autor de Viver a Vida em entrevista ao Fantástico desse mesmo dia.

Patrícia Poeta (em off): Entre tantos personagens reais que apareceram nos finais de Viver a Vida, um chamou atenção especial: Ronaldo Miguel Monteiro.

"Uma experiência muito forte para mim foi encontrar uma das minhas vítimas", relata Ronaldo, em um dos depoimentos finais de Viver a Vida. Trata-se da história de um expresidiário, condenado a 28 anos de prisão por ter cometido ação criminosa envolvendo 10 sequestros. Anos depois, o empresário Custódio Rangel, uma de suas vítimas, o visita na prisão, o que transforma a vida de Ronaldo que, encarcerado, passou a se envolver com projetos sociais. Depois de cumprir 13 anos de prisão, ganhou direito à condicional. Saiu da cadeia, trabalhou dois anos com Seu Custódio e passou a coordenar uma ONG que ajuda presos a se qualificarem profissionalmente.

Depois de abrir com esta matéria, Zeca Camargo (em off) anuncia outros destaques do Fantástico daquele dia: O Fantástico vai contar também as histórias de pessoas que tiveram a mesma sensação de Tereza, personagem de Lilia Cabral em Viver a Vida. Como explicar o pressentimento de alguma coisa ruim vai acontecer?

Zeca Camargo: Esta semana a personagem Tereza da novela Viver a Vida se sentiu muito mal em casa no instante exato em que a filha Luciana sofria um grave acidente a milhares de quilômetros de distância.

Patrícia Poeta: E na vida real isso tudo também acontece. Você vai ver agora histórias de sensações e sonhos estranhos que avisam com uma precisão impressionante quando o perigo está para acontecer. 
Zeca Camargo: Existe explicação para este fenômeno e ela está dentro do nosso cérebro.

Entra a cena da novela em que Tereza tem o pressentimento. Na sequência, a produção do programa entrevista pessoas que pressentiram grandes tragédias com a consequente morte de seus entes queridos. Entre estes entrevistados, estão pessoas que sentiram sensações estranhas antes de acidentes, entre eles, casos famosos como o do ataque de skinheads em um trem no interior de São Paulo, em dezembro de 2003, no qual dois jovens tiveram que pular da janela do interior do vagão em movimento deixando um morto e outro com o braço amputado. O pai do menino, que perdeu um dos braços, afirma que teve um sonho exatamente com um trem no qual entravam algumas pessoas sem braços e outras sem pernas. Outro caso de um cirurgião plástico que salvou sua vida ao ter um pressentimento de um acidente aéreo. Ele acabou não embarcando e se salvou do acidente do voo 402 da TAM, ocorrido em outubro de 1996, em São Paulo. A própria Lilia Cabral, intérprete da personagem Tereza, afirma que teve um pressentimento em relação a sua filha que sofreu um acidente na vida real no qual um vergalhão rasgou parte de sua face, quase a deixando cega. No final da matéria, uma neurocientista explica como esses fenômenos se manifestam no cérebro. Deve-se ressaltar que a novela Viver a Vida forneceu assunto de pauta tanto para o início quanto para o final do Fantástico daquele domingo. Tradicionalmente, as matérias mais importantes dos telejornais entram no início e no final das edições, o que comprova a importância dessas histórias do campo da ficcionalidade, que estimulam as pautas de telejornais a abordarem esses assuntos na factualidade.

Na edição da semana seguinte, em 15/11/2009, o Fantástico repete a estratégia e abre o programa com a entrevista de Aline Moraes, intérprete de Luciana, personagem de Viver a Vida, que sofre um grave acidente e fica tetraplégica. A atriz conta como foi o processo de preparação e os desafios para fazer este personagem. Na sequência, entra chamada - como uma das matérias mais importantes daquela edição - de uma entrevista com pessoas que enfrentaram o mesmo problema da personagem da ficção.

Patrícia Poeta: A história que você vai conhecer agora foge de quase tudo do que se sabe sobre tetraplegia, a paralisia dos movimentos que atinge Luciana, personagem de Aline Moraes na novela Viver a Vida.

Zeca Camargo: É a história real de uma mulher que sofreu lesão na medula e ouviu do médico que jamais voltaria a andar, mas voltou. 
Patrícia Poeta: É uma conquista que serve de inspiração.

Repórter (em off): Camila e Kristie passaram pela mesma dor que Luciana da novela Viver a Vida sentiu esta semana. Quem vê a Kristie, essa mulher bonita de 41 anos, jogadora de polo internacional, nunca vai imaginar que ela tem uma história parecida com a personagem Luciana da novela Viver a Vida. A Kristie, aos 17 anos, também era modelo, sofreu um acidente (Kristie foi atingida na cabeça por um portão) e ficou tetraplégica como a personagem da novela. Kristie levou dez anos para conseguir andar sozinha. Após algumas entrevistas, a repórter enfoca o caso de outra vítima.

Repórter (em off): A Camila ficou tetraplégica aos 12 anos, ela está com 23 anos, vítima de uma bala perdida. (Camila recuperou o movimento dos braços e luta para voltar a andar). A doutora Lucia explica que não há na história da medicina reversão da tetraplegia quando a ruptura da medula é total e que, nos casos de ruptura parcial como o de Kristie, apenas $2 \%$ dos pacientes voltam a andar, e Kristie fez de tudo para estar entre eles.

Desse modo,

A convergência entre telejornalismo e telenovela, que se observa no conteúdo, revela-se também na estrutura formal de telejornais e telenovelas. Tomadas, cenas, e sequências curtas, uma edição extremamente ágil, uso preferencial de planos fechados, diálogos e narrações em uma linguagem coloquial que facilite o exercício da função fática, conferem tanto ao telejornal quanto à telenovela o tom de espetáculo que padroniza a programação televisiva. (Rezende, 2005, p. 05)

\subsubsection{Telenovela e Hibridação}

Seguimos na hipótese de que, para melhor compreender as tendências da telenovela brasileira da contemporaneidade, a hibridação é um conceito-chave que nos ajuda a elucidar as relações entre a realidade e a ficção cada vez mais evidentes no formato. Essa hibridação pode ter várias chaves de entrada no objeto, como as relações entre o melodrama e as diversas formas de gêneros (drama, comédia, romance, suspense, etc); a hibridação entre culturas distintas quando as tramas são ambientadas em outros países e demonstram um tráfico cultural constante e interação entre as nações (Straubhaar, 2004), como em O Clone (Brasil e Marrocos), América (Brasil e Estados Unidos) e Caminho das índias (Brasil e índia); a hibridação entre o global e o local, onde o fluxo televisivo se dá pela importação de padrões globais apesar de a produção ser local (nacional), a exemplo de programas de realities shows 
como Big Brother e American Idol, cuja ideia original é creditada à Holanda e aos Estados Unidos, respectivamente, que licenciam os formatos e obrigam todos os países do globo terrestre a seguirem os padrões originais, porém, adaptando-os à cultura local; a hibridação entre o tradicional e o moderno ou entre o culto e o popular.

Ser culto, e inclusive ser culto moderno, implica não tanto vincular-se a um repertório de objetos e mensagens exclusivamente modernos, quanto saber incorporar a arte e a literatura de vanguarda, assim como os avanços tecnológicos, matrizes tradicionais de privilégio e distinção simbólica. (Garcia Canclini, 2001, p. 74)

Em particular, na telenovela, os termos tradicional e moderno são utilizados por Martín-Barbero (2004) para se referir a um modo de construção narrativa que segue o folhetim tradicional com forte carga melodramática, e o modo moderno, inaugurado no Brasil em 1968 com a novela Beto Rockfeller, que "sem romper em tudo com o esquema melodramático, incorpora um realismo que permite a cotidianização da narrativa" (2004, p. 39) e, em particular, a hibridação entre o documental a o ficcional que, acreditamos, ter se desenvolvido mais fortemente a partir da novela $O$ Clone, de Glória Perez em 2001.

As razões de se apontar a novela $O$ Clone como uma espécie de divisor de águas na periodização da telenovela brasileira são muitas. Algumas delas trabalharemos ao longo desta investigação. Entretanto, um esclarecimento inicial se faz necessário: observa-se nessa obra uma combinação entre a realidade e ficção fortemente explicitada. As referências feitas a fatos exteriores à narrativa ficcional funcionam como uma espécie de documento, um atestado de que aquelas cenas são reais, representadas por pessoas reais (não atores) e que seus referentes sejam reconhecidos pelos espectadores como realidade e não como ficção. Por outro lado, $O$ Clone inaugura uma tendência de localização das narrativas em terras internacionais.

Não por acaso, das 12 novelas produzidas durante o período das novelas híbridas, a partir de $O$ Clone em 2001, exibidas no prime-time da Globo, 8 (67\%) iniciaram ou localizaram as tramas no exterior ${ }^{29}$, conforme ilustramos a seguir:

29 Embora a ênfase desta investigação resida nas novelas das 21 horas da TV Globo que, tradicionalmente, recebem os maiores investimentos e manifestam as principais experimentações, inovações e transformações no formato, salientamos que outras obras seguiram esta tendência de investir em gravações internacionais, como as novelas das 19 horas A Lua me Disse (Globo, 2005), na qual foram gravadas cenas na cidade de Innsbruck, na Áustria, Bang Bang (Globo, 2005), com cenas rodadas no Chile, Três Irmãs (Globo, 2008) realizou cenas em Bali, na Indonésia, e Caras \& Bocas (Globo, 2009), na África do Sul. Na TV Record, a 
Tabela 3: Novelas Híbridas- TV Globo - (a partir de 2001)

\begin{tabular}{|c|c|c|c|c|c|c|}
\hline & Título & Ano & Autor & $\begin{array}{l}\text { Cidade no } \\
\text { Brasil onde a } \\
\text { trama foi } \\
\text { localizada }\end{array}$ & $\begin{array}{l}\text { País/ } \\
\text { exterior }\end{array}$ & $\begin{array}{l}\text { Referências } \\
\text { ao "real" } \\
\text { evidenciadas na } \\
\text { trama. }\end{array}$ \\
\hline 01 & O Clone & 2001 & Glória Perez & $\begin{array}{l}\text { Rio de } \\
\text { Janeiro }\end{array}$ & Marrocos & $\begin{array}{l}\text { Depoimentos de pessoas } \\
\text { "reais" vítimas das } \\
\text { drogas. } \\
\text { No bar da Jura } \\
\text { (personagem da ficção) } \\
\text { diversas celebridades } \\
\text { "reais", como Pelé, } \\
\text { Alcione e Ana Maria } \\
\text { Braga, interagiram com } \\
\text { personagens da trama. }\end{array}$ \\
\hline 02 & Esperança & 2002 & $\begin{array}{l}\text { Benedito Rui } \\
\text { Barbosa }\end{array}$ & São Paulo & Itália & ******** \\
\hline
\end{tabular}

"continua"

novela Vidas Opostas (Record, 2005) teve gravações em Portugal, Caminhos do Coração (Record, 2006) teve cenas em Miami, nos Estados Unidos, Poder Paralelo (Record, 2009), em Palermo, na Itália. Destacamos ainda que a novela das 21 horas Laços de Família (Globo, 2000) teve cenas gravadas no Japão e Duas Caras (Globo, 2007) em Paris. 


\begin{tabular}{|c|c|c|c|c|c|c|}
\hline & Título & Ano & Autor & $\begin{array}{l}\text { Cidade no } \\
\text { Brasil onde a } \\
\text { trama foi } \\
\text { localizada }\end{array}$ & $\begin{array}{l}\text { País/ } \\
\text { exterior }\end{array}$ & $\begin{array}{l}\text { Referências } \\
\text { ao "real" } \\
\text { evidenciadas na } \\
\text { trama. }\end{array}$ \\
\hline 03 & Celebridade & 2003 & $\begin{array}{l}\text { Gilberto } \\
\text { Braga }\end{array}$ & $\begin{array}{l}\text { Rio de } \\
\text { Janeiro }\end{array}$ & $\begin{array}{l}\text { França/ } \\
\text { Inglater- } \\
\text { ra }\end{array}$ & $\begin{array}{l}\text { Por conta de um } \\
\text { bombeiro da ficção, o } \\
\text { capitão José Albucacys } \\
\text { virou celebridade } \\
\text { instantânea e bombeiros } \\
\text { da vida "real" que } \\
\text { haviam pousado para o } \\
\text { calendário "Heróis do } \\
\text { Rio" fazem uma } \\
\text { participação na trama. } \\
\\
\text { Diversas celebridades } \\
\text { da vida real } \\
\text { participaram da trama, } \\
\text { como o escritor João } \\
\text { Ubaldo Ribeiro, Marina } \\
\text { Lima, Rita Lee, Erasmo } \\
\text { Carlos, Roberto Carlos e } \\
\text { três celebridades } \\
\text { instantâneas da quarta } \\
\text { edição do Big Brother } \\
\text { Brasil. No último } \\
\text { capítulo, o então } \\
\text { Ministro da Cultura, } \\
\text { Gilberto Gil aparece } \\
\text { cantando e até mesmo } \\
\text { Gilberto Braga, autor da } \\
\text { trama, é convidado para } \\
\text { o evento. }\end{array}$ \\
\hline 04 & $\begin{array}{l}\text { Senhora do } \\
\text { Destino }\end{array}$ & 2004 & $\begin{array}{l}\text { Aguinaldo } \\
\text { Silva }\end{array}$ & Rio de Janeiro & $* * * * * * *$ & $\begin{array}{l}\text { Aguinaldo Silva se } \\
\text { inspirou no famoso caso } \\
\text { conhecido como "o } \\
\text { sequestro do menino } \\
\text { Pedrinho", ocorrido em } \\
\text { Goiânia, em 1986. Na } \\
\text { vida "real", Vilma } \\
\text { Martins Costa sequestra } \\
\text { o menino Pedro Tapajós } \\
\text { Braule Pinto de sua mãe } \\
\text { biológica em um } \\
\text { hospital. Na ficção, } \\
\text { Maria do Carmo } \\
\text { (Suzana Vieira) tem sua } \\
\text { filha sequestrada por } \\
\text { Nazaré (Renata Sorrah). }\end{array}$ \\
\hline
\end{tabular}

"continuação" 


\begin{tabular}{|c|c|c|c|c|c|c|}
\hline & Título & Ano & Autor & $\begin{array}{l}\text { Cidade no } \\
\text { Brasil onde a } \\
\text { trama foi } \\
\text { localizada }\end{array}$ & $\begin{array}{l}\text { País/ } \\
\text { exterior }\end{array}$ & $\begin{array}{l}\text { Referências } \\
\text { ao "real" } \\
\text { evidenciadas na } \\
\text { trama. }\end{array}$ \\
\hline 05 & América & 2005 & Glória Perez & $\begin{array}{l}\text { Rio de } \\
\text { Janeiro }\end{array}$ & $\begin{array}{l}\text { Estados } \\
\text { Unidos }\end{array}$ & $\begin{array}{l}\text { Dudu Braga, filho de } \\
\text { Roberto Carlos, } \\
\text { apresentou o programa: } \\
\text { "É preciso saber viver", } \\
\text { no qual entrevistava } \\
\text { pessoas que, assim } \\
\text { como ele, eram } \\
\text { deficientes visuais. }\end{array}$ \\
\hline 06 & Belíssima & 2005 & $\begin{array}{l}\text { Sílvio de } \\
\text { Abreu }\end{array}$ & São Paulo & Grécia & $* * * * * * * *$ \\
\hline 07 & $\begin{array}{l}\text { Páginas da } \\
\text { Vida }\end{array}$ & 2006 & $\begin{array}{l}\text { Manoel } \\
\text { Carlos }\end{array}$ & $\begin{array}{l}\text { Rio de } \\
\text { Janeiro }\end{array}$ & Holanda & $\begin{array}{l}\text { Inserção de } \\
\text { depoimentos "reais" de } \\
\text { pessoas que relatavam } \\
\text { seus dramas de vida. } \\
\text { Destaque para os relatos } \\
\text { dos pais do menino } \\
\text { Hélio, brutalmente } \\
\text { assassinado em } 2007 . \\
\text { Preso a um cinto de } \\
\text { segurança, ele foi } \\
\text { arrastado por } 7 \\
\text { quilômetros. } \\
\text { Citação de um ônibus } \\
\text { incendiado após assalto } \\
\text { no Rio de Janeiro em } \\
\text { 28/12/2006. Na vida } \\
\text { real, modelo Beatriz } \\
\text { Furtado e outros } \\
\text { passageiros ficam } \\
\text { gravemente feridos. Na } \\
\text { ficção, uma personagem } \\
\text { da trama morre. } \\
\\
\text { Citou o } 11 \text { de setembro } \\
\text { criando uma cena que } \\
\text { mistura ficção e } \\
\text { realidade. Os } \\
\text { personagens } \\
\text { acompanhavam a } \\
\text { tragédia pela televisão. } \\
\text { Na ficção, uma das } \\
\text { personagens estava no } \\
\text { local da tragédia. }\end{array}$ \\
\hline
\end{tabular}

"continuação" 


\begin{tabular}{|c|c|c|c|c|c|c|}
\hline & Título & Ano & Autor & $\begin{array}{l}\text { Cidade no } \\
\text { Brasil onde a } \\
\text { trama foi } \\
\text { localizada }\end{array}$ & $\begin{array}{l}\text { País/ } \\
\text { exterior }\end{array}$ & $\begin{array}{l}\text { Referências } \\
\text { ao "real" } \\
\text { evidenciadas na } \\
\text { trama. }\end{array}$ \\
\hline 08 & $\begin{array}{l}\text { Paraíso } \\
\text { Tropical }\end{array}$ & 2007 & Gilberto Braga & Rio de Janeiro & $* * * * * * * *$ & $\begin{array}{l}\text { A personagem Bebel, } \\
\text { interpretada por Camila } \\
\text { Pitanga, fez citação a } \\
\text { Mônica Velozo, fazendo } \\
\text { alusão aos últimos } \\
\text { escândalos envolvendo } \\
\text { políticos em Brasília. }\end{array}$ \\
\hline 09 & Duas Caras & 2007 & $\begin{array}{l}\text { Aguinaldo } \\
\text { Silva }\end{array}$ & Rio de Janeiro & $* * * * * * * *$ & $\begin{array}{l}\text { O personagem principal } \\
\text { da trama foi inspirado } \\
\text { em José Dirceu, ex- } \\
\text { chefe da Casa Civil, que } \\
\text { viveu um tempo exilado } \\
\text { em Cuba e fez cirurgia } \\
\text { plástica passando a } \\
\text { viver na clandestinidade } \\
\text { com outro nome. } \\
\text { Citação da tragédia } \\
\text { conhecida como } \\
\text { "Ônibus 174”, ocorrida } \\
\text { no Rio de Janeiro em } \\
\text { 2002. } \\
\text { A personagem Branca, } \\
\text { interpretada por Suzana } \\
\text { Vieira, foi afastada de } \\
\text { seu cargo na fictícia } \\
\text { Universidade Pessoa de } \\
\text { Moraes, da qual também } \\
\text { era proprietária, por usar } \\
\text { o cartão da empresa em } \\
\text { benefício particular. } \\
\text { Uma clara referência ao } \\
\text { escândalo dos cartões } \\
\text { corporativos envolvendo } \\
\text { políticos em Brasília, } \\
\text { em 2007. }\end{array}$ \\
\hline 10 & A Favorita & 2008 & $\begin{array}{l}\text { João Emanuel } \\
\text { Carneiro }\end{array}$ & São Paulo & $* * * * * * * *$ & $* * * * * * *$ \\
\hline 11 & $\begin{array}{l}\text { Caminhos } \\
\text { das Índias }\end{array}$ & 2009 & Glória Perez & $\begin{array}{l}\text { Rio de } \\
\text { Janeiro }\end{array}$ & Índia & $\begin{array}{l}\text { Personagens da ficção } \\
\text { contracenam com } \\
\text { pacientes } \\
\text { esquizofrênicos (reais). }\end{array}$ \\
\hline 12 & Viver a Vida & 2009 & $\begin{array}{l}\text { Manoel } \\
\text { Carlos }\end{array}$ & $\begin{array}{l}\text { Rio de } \\
\text { Janeiro }\end{array}$ & $\begin{array}{l}\text { França/ } \\
\text { Jordânia }\end{array}$ & $\begin{array}{l}\text { Relatos dramáticos e de } \\
\text { superação de pessoas } \\
\text { reais. }\end{array}$ \\
\hline
\end{tabular}

"conclusão" 
É importante destacar que a última novela antes de 2001, portanto antes das novelas híbridas e que antecede $O$ Clone, foi Porto dos Milagres, de Aguinaldo Silva e Ricardo Linhares. Há quase uma década que as novelas do prime-time da Globo não apresentam tramas que desenrolam suas histórias no campo ou no interior do Brasil, característica marcante das novelas realistas nas décadas de 1970 e 1980. Porto dos Milagres (Globo, 2001) foi ambientada numa cidade fictícia de mesmo nome do título do folhetim e localizada no recôncavo baiano. Nas novelas híbridas há uma clara preferência no retrato da vida urbana nas metrópoles. Conforme observamos no quadro anterior, dos 12 títulos, 9 (75\%) foram localizadas no Rio de Janeiro e 3 (25\%) em São Paulo. Ademais, é inevitável notar que a internacionalização da telenovela ultrapassa uma simples exportação dos capítulos para exibição no exterior e cada vez mais traz o exterior para dentro da telenovela, localizando as tramas em países como Marrocos, Grécia, Estados Unidos, Jordânia, Itália e Holanda. Tendência, talvez, impulsionada pelo interesse cada vez maior da indústria da cultura em conquistar o mercado mundial, já que o fato de as tramas se desenrolarem além das fronteiras brasileiras não representa, aparentemente, qualquer inovação ou função narrativa. É possível, portanto, em se falar em uma mundialização da telenovela? Ortiz (2006) distingue os termos global de mundial. Para o autor, global é utilizado para processos econômicos e políticos e a ideia de mundial para as questões culturais. Nesse contexto, observamos que as telenovelas contemporâneas estão além de um processo de internacionalização porque, de um certo modo, elas estão sendo "mundializadas" na medida em que suas narrativas atravessavam os limites territoriais ambientando suas tramas em países como Estados Unidos, Jordânia, Holanda e Índia ${ }^{30}$.

Outra particularidade das novelas híbridas é a forte tendência de abordar assuntos contemporâneos e tecnológicos, bem como a aceleração da vida urbana típica da vida pósmoderna. Nesse sentido, destacamos a entrevista do diretor de novelas, Jorge Fernando, publicada no jornal "Gazeta do Povo" - revista da TV, Curitiba, domingo, 9 de setembro de 2007:

30. É importante sublinhar que a internacionalização ou a mundialização da telenovela já está contemplada em outros estudos. Nesse sentido, destacamos o Seminário Internacional de Telenovela: A Internacionalização da Telenovela no Cenário Globalizado, realizado nos dias 24 e 25 de outubro de 2002, na Escola da Comudações e Artes da Universidade de São Paulo. Desse encontro resultou o livro Telenovela: Internacionalização $e$ interculturalidade (2004), no qual renomados pesquisadores internacionais e nacionais se debruçaram sobre o assunto. 
(...) Outro dia estava falando sobre a dificuldade do autor de retratar seu momento. $\mathrm{O}$ autor contemporâneo tem milhões de histórias. Tudo fragmentado e frenético. É difícil mostrar a realidade. O que acontece de coisas, o que a gente muda de opinião, de sentimentos! Antes as novelas ficavam três meses com o "segredo da carta". Hoje, não pode ter o "segredo do e-mail" nem por um dia.

Outro exemplo de aceleração das narrativas pode ser ilustrado com a novela $A$ Favorita (Globo, 2008), escrita por João Emanuel Carneiro. Ao contrário do que se espera, a trama principal não girava em torno de um casal de apaixonados que enfrentam toda espécie de obstáculos para ficarem juntos no final da trama. Duas personagens femininas, Flora (Patrícia Pilar) e Donatela (Cláudia Raia), provocam um mistério que, em outras épocas, poderia ser revelado no último capítulo. Quem é a vilã? Que é a assassina? O público não comprou essa ideia e o autor teve que revelar no meio da trama que Flora é a assassina e, a partir de então, a trama ganhou novo fôlego. Em A Favorita, as tramas de desenrolavam rapidamente quase que sem aqueles famosos tempos mortos da telenovela onde nada acontece. Por outro lado, além de os fatos de desenrolarem mais rapidamente, as narrativas das telenovelas contemporâneas dão conta do desenvolvimento de tecnologias modernas como celulares, internet, sites de relacionamento, etc. É bastante comum um personagem no Brasil trocar mensagens com imagens e em tempo real com outros personagens na Índia, Jerusalém e Jordânia. Com efeito, em uma era de revolução digital, as narrativas experimentam novos tempos e espaços em suas tramas buscando representar o século XXI que emerge em tempos de globalização, internacionalização ou mundialização da cultura.

As inovações tecnológicas (parabólicas e satélites, televisão digital, televisão a cabo, televisão satelital) implementaram a vocação transnacional da televisão, favorecendo a circulação sem fronteiras de produtos, mas também de formatos, personagens, temas, etc. Segundo um modelo que parece configurar-se cada vez menos como uma "macdonaldização" da sociedade, e sempre mais como uma galáxia compósita na qual, frente a produtos e formatos extremamentes estandarlizados, vão se afirmando níveis diversificados de identidade: subnacionais, nacionais, transnacionais (como sucede nos esforços de construção de uma cultura européia), internacionais (onde tornam-se disponíveis produtos de culturas pertencentes ao sul e ao leste do mundo. (Lopes, 2004, p. 36-37)

Em sintonia com as transformações científicas e tecnológicas, as novelas híbridas buscam retratar essas temáticas em suas obras conforme afirma Glória Perez: 
Tem um tema que é muito recorrente para mim, eu vou acabar isso e vou falar como é o processo de trabalho. Tem um tema que eu sempre busco que são as inovações tecnológicas e inovações da medicina, porque eu acho que a gente está vivendo uma época, o final do século passado, começo desse, uma grande revolução. Cada técnica nova que é introduzida modifica o cotidiano das pessoas, mesmo que as pessoas não percebam isso. Essa é a proposta de reflexão que eu incluo nos meus trabalhos que algumas pessoas podem captar, é um convite para pensar sobre o assunto. Como a gente vive experiências hoje criadas por essas inovações tecnológicas sem nenhuma referência do passado, que nenhuma geração viveu antes que a nossa. ${ }^{31}$

\subsubsection{Telenovela e Globalização}

De todo modo, acentuamos a necessidade de inserir o estudo das novelas híbridas na atual fase dos estudos de comunicação, que está intimamente ligada aos processos de globalização em curso, em que identificamos uma cultura mundializada e profundas mudanças estruturais na sociedade contemporânea.

A globalização pode assim ser definida como a intensificação das relações sociais em escala mundial, que ligam localidades distantes de tal maneira que acontecimentos locais são modelados por eventos ocorrendo a muitas milhas de distância e vice-versa. (Ianni, 1994, p. 151).

Desse modo, inevitavelmente e irreversivelmente, todos vivemos em um mundo globalizado, no qual uma crise no mercado imobiliário norte-americano ou uma instabilidade econômica em Dubai provocam a queda das bolsas de valores em praticamente todo o globo terrestre. Impulsionada pelo desenvolvimento das altas tecnologias, ela provoca a diluição do tempo e espaço entre as fronteiras territoriais tradicionais e estimula a interculturalidade, ou culturas distintas que se conectam ou interagem. Nessa perspectiva, Lopes (2004) pontua que a difusão dos meios de comunicação, possibilitada pelo desenvolvimento das tecnologias do último século, ao lado da intensificação dos processos migratórios "estão associados à ideia de mobilidade (circulação de ideias, experiências, homens, imagens, símbolos e significados) e, portanto, de modernização potencial, sendo a viagem - real e simbólica-, na ideia de cultura, uma extraordinária ativação de energias e capacidades”. (Lopes, 2004, p. 124)

Neste cenário, Bauman (1999) afirma que hoje em dia estamos todos em movimento e complementa:

\footnotetext{
${ }^{31}$ PEREZ, Glória. Palestra proferida no I Encontro Nacional Obitel em São Paulo, 28 nov. 2007.
} 
Muitos mudam de lugar - de casa ou viajando entre locais que não são o da residência. Alguns não precisam sair para viajar: podem se atirar à web, percorrê-la, inserindo e mesclando na tela do computador mensagens provenientes de todos os cantos do globo. Mas a maioria está em movimento mesmo se fisicamente parada - quando, como é hábito, estamos grudados na poltrona e passando na tela dos canais de TC via satélite ou a cabo, saltando para dentro e para fora de espaços estrangeiros com uma velocidade muito superior à dos jatos supersônicos e foguetes interplanetários, sem ficar em lugar algum tempo suficiente para ser mais que visitantes, para nos sentirmos em casa. (1999, p. 85)

Pensar essa questão da mobilidade na telenovela é pensar em sua circulação enquanto produto e enquanto narrativa. Como produto e, portanto, sob um aspecto mercadológico, as telenovelas já viajam pelo mundo afora desde a década de 1970. "A telenovela é o único texto televisivo que viaja de ponta a ponta da América Latina e pelo resto do mundo em nas mais diversas direções, dando significado ao que é viajar do Sul ao Norte”, pondera MartínBarbero (2004, p. 24). A globalização da telenovela permitiu o avanço das fronteiras de inúmeras produções latino-americanas que conquistaram espaço em países como Estados Unidos, Espanha, Portugal, Peru, México, Argentina, Uruguai, China e até em países distantes territorialmente e culturalmente como Azerbaijão, Geórgia e Croácia. Na lista de exportações encontram-se Da cor do Pecado em 100 países, Terra Nostra em 95 países, O Clone - 90 países, Escrava Isaura - 79 países, Por Amor - 74 países, Mulheres de Areia e Anjo Mau 62 países, Sinhá Moça- 60 países, Laços de Família - 56 países e O Rei do Gado em 55 países. $^{32}$

Na América Latina, são clássicos os exemplos de novelas que correram o mundo como as mexicanas Os Ricos Também Choram (Televisa, 1979), Simplesmente Maria (Televisa, 1989) e Chispita (Televisa, 1982), e as colombianas Café e Yo soy Betty, la Fea (RCN, 1999). Muito além que uma mera exportação de capítulos já prontos e dublados, a tendência mais recente é o de se vender a sinopse que será regravada e produzida no país que a importou e que, portanto, configura a mobilidade da telenovela enquanto narrativa, já que a trama será refeita adaptando-se, de algum modo, à cultura local. É o caso de Yo soy Betty, la fea. Esta novela representa um fenômeno mundial na medida em que foi produzida em forma de remake em mais de 20 países com títulos diferentes: Ne rodis 'Krasivoy - (Não nasci bonita -

32. Segundo informações da Agência Estado divulgadas no site:

http://www.midiainteressante.com/2009/05/voce-sabe-qual-e-novela-mais-vista-do.html acessado em

21/11/2009. 
Rússia, 2005), La fea más bella (A feia mais bonita, México 2006), Ugly Betty (Betty, a feia - Estados Unidos e Canadá, 2006, produzida na forma de série) e mais recentemente no Brasil: Bela, a feia (Record, 2009), fruto de um acordo entre as emissoras brasileiras e mexicanas representadas pela Record e pela Televisa. Com uma sinopse extremante simples cujo plot central gira em torno da feiura de uma jovem de 26 anos que usa aparelhos nos dentes, óculos fundo de garrafa e se veste mal, a história tem viajado o mundo e despertado o imaginário de espectadores dotados de identidade, cultura e repertórios distintos. Nesse sentido, Ortiz (2006) nos esclarece que o termo globalização é um fenômeno emergente e em processo de construção e não é uma mera internacionalização de produtos ou de conhecimentos. É uma forma ainda mais complexa e desenvolvida da internacionalização: “o conceito se aplica, portanto, à produção, distribuição e consumo de bens e serviços, organizados a partir de uma estratégia mundial, e voltada para um mercado mundial". (Ortiz, 2006, p. 16).

São também proeminentes as novelas que avançam os limites de fronteiras nacionais na forma de co-produção. Em 2002, a Globo, em co-produção com a Telemundo ramificação hispânica da rede de TV estadunidense NBC, produziu o remake de Vale Tudo, escrita por Gilberto Braga e grande sucesso nacional na década de 1980. Com o título de Vale Todo, adaptada por Yves Dumont, a novela reuniu atores de primeiro time do Brasil, México, Peru, Cuba, Colômbia e Venezuela. Gravada nos estúdios de Projac no Rio de Janeiro, a novela não atingiu o resultado esperado nos Estados Unidos. Sete anos mais tarde, Globo e Telemundo investem novamente em uma produção híbrida. Dessa vez, a novela $O$ Clone, de Glória Perez, está sendo refeita com o título de El Clon. Com estreia ocorrida em março de 2010, a novela está sendo gravada na Colômbia e pretende trabalhar com elementos narrativos que agradem o público latino, asiático e europeu.

Assim exposto, pode-se afirmar que as telenovelas contemporâneas ou novelas híbridas são pautadas por um cenário cada vez mais globalizado que, direta ou indiretamente, interfere nas produções das tramas tornando a telenovela cada vez mais viajante (MartínBarbero) e que traz para si algumas características deste fenômeno como a aceleração, hibridação, e internacionalização ou mundialização e a mobilidade.

Como vimos, esta mobilidade manifesta-se nas tramas pelas trocas de ideias, interculturalidade, intercâmbio de símbolos e sentimentos quando as novelas são exportadas ou refeitas na forma de co-produção. Mas essa mobilidade se dá também pelo fluxo de 
pessoas ou de personagens que transitam rapidamente entre nações distantes "como se o espaço não passasse de um convite contínuo a ser desrespeitado, refutado, negado. O espaço deixou de ser um obstáculo - basta uma fração de segundo para conquistá-lo". (Bauman, 1999, p. 85). Viaja-se, na ficção, do Rio de Janeiro a Miami, a Petra, a Foz, a Paris ou a outras cidades famosas do globo terrestre como se pegássemos um metrô na zona norte de São Paulo e chegássemos rapidamente na zona sul; os personagens viajam na condição de turista ou de vagabundo (Bauman, 1999).

\begin{abstract}
Os turistas ficam ou se vão a seu bel-prazer. Deixam um lugar quando novas oportunidades ainda não experimentadas acenam de outra parte. Os vagabundos sabem que não ficarão muito tempo num lugar, por mais que o desejem, pois provavelmente em nenhum lugar onde pousem serão bem recebidos. Os turistas se movem porque acham o mundo a seu alcance (global) irresistivelmente atraente. Os vagabundos se movem porque acham o mundo a seu alcance (local) insuportavelmente inóspito. Os turistas viajam porque querem; os vagabundos porque não têm outra opção suportável. (Bauman, 1999, p. 101).
\end{abstract}

Se, no passado, as telenovelas representavam essa mobilidade, essa migração da população dentro dos limites territoriais da nação, ou seja, o esvaziamento das populações no campo que saiam em busca de melhores condições de vida nos grandes centros urbanos, no período contemporâneo, a mobilidade acontece não mais somente em âmbito nacional, mas transnacional. Impulsionados pela crise social, política e econômica que assola boa parte dos países da América Latina, emigrantes embarcam para os países do hemisfério norte, principalmente Estados Unidos, Canadá e Europa, em busca da promessa e desejo de ascensão social. Nesse cenário, a novela América (Globo, 2005) de Glória Perez é emblemática: ela tem como ponto central da trama a emigração de uma personagem que arrisca a própria vida atravessando o deserto mexicano para cruzar a fronteira dos Estados Unidos. América estreou na Rede Globo de televisão no dia 14 de março de 2005 e terminou no dia 04 de novembro do mesmo ano. A novela conta a história de Sol (Deborah Secco), uma moça pobre que morou a vida inteira numa favela carioca e viu sua casa ser demolida quando criança. Tal fato a fez acreditar que no Brasil não existe possibilidade de o pobre progredir na vida, o que lhe faz despertar o interesse de tentar a vida nos Estados Unidos. Como o visto de entrada fora negado, Sol decidiu entrar no país de maneira ilegal, assim como fazem milhares de outros latino-americanos. Neste ínterim, ela conhece Tião (Murilo Benício) e se apaixonam à primeira vista. Eles têm muita coisa em comum: jovens, bonitos e 
pertencentes a uma classe social menos abastada. Contudo, divergem nos sonhos: enquanto Sol deseja morar nos Estados Unidos, trabalhar e receber um salário justo para ajudar sua família, Tião sonha em se tornar campeão do rodeio de Barretos-SP. A diferença de sonhos cria o conflito que separa o par romântico Sol e Tião. A mocinha consegue atravessar o deserto e entrar ilegalmente nos Estados Unidos. Em Miami, a personagem descobre que a vida nos Estados Unidos não é tão fácil como pensava. Ela trabalha como faxineira, dançarina de boate e até de estátua viva para ganhar dinheiro. No meio dessas turbulências, ela conhece Edward (Caco Ciocler) e com o tempo os dois acabam se apaixonando, o que causa o ódio da vilã May (Camila Morgado).

De outra parte, convém ressaltar que, em América, além do plot imigração ilegal, é possível enumerar diversas outras temáticas retratadas nesta telenovela, como homossexualidade reprimida, pedofilia, gravidez psicológica, cleptomania, sequestro, tráfico internacional de drogas, entre outras. Pelo exposto, é admissível apontar que as telenovelas brasileiras, a exemplo de América e $O$ Clone, têm abandonado a maneira tradicional de produzir ficção seriada e absorvido cada vez mais aspectos do cotidiano da sociedade, diversidades temáticas produzindo narrativas mais complexas e menos lineares e, nesse triângulo indissociável entre melodrama, folhetim e telenovela, o Brasil e, em especial a TV Globo, desenvolveu mecanismos próprios de produção de teleficção capaz de combinar o arcaico e o moderno, o erudito e o popular e, em particular, a ficção e a realidade.

\subsubsection{Telenovela e Antificção}

Indubitavelmente, a telenovela é considerada uma obra de ficção, na qual atores profissionais interpretam personagens com características criadas e imaginadas por um autor. Até aproximadamente o início dos anos 90, era comum a principal emissora de televisão do país, representada pela TV Globo, incluir nos créditos finais da obra a seguinte advertência: essa é uma obra de ficção, qualquer semelhança com nomes, pessoas ou acontecimentos reais terá sido mera coincidência. Este esclarecimento já sinalizava na época a complexidade conceitual desta obra que se assumia como ficcional, mas que admitia semelhanças e referências com o mundo real ou não ficcional. Duplamente contraditório é o fato de que, durante anos, esses créditos insistiram em enfatizar que a telenovela é pura ficção ao mesmo tempo que fazia explícitas referências ao "mundo real" através de citações de momentos 
históricos e políticos do Brasil conforme já apontamos anteriormente.

Como é óbvio, a combinação entre ficção e não ficção traz pontos de vista que não permitem pensar a telenovela como uma obra exclusivamente ficcional. Se admitíssemos a existência de uma fronteira rígida entre a ficção e não ficção, o que dizer dos depoimentos de pessoas reais que apareciam no final de cada capítulo da novela Páginas da vida, comentando, com exemplos próprios, fatos que a obra abordou naquele dia como homossexualidade, bulimia e alcoolismo, entre outros, ou dos depoimentos que finalizam cada capítulo de Viver a Vida (Globo, 2009)?

Apesar destas evidentes intervenções do "real", não resta dúvida de que a telenovela faz parte do campo ficcional, pois é um produto fruto da imaginação de autores de televisão que imprimem suas experiências e estilos narrativos às tramas, criando personagens, situações e dramas familiares produzidos em escala industrial e interpretados por um casting de atores amplamente conhecidos e reconhecidos pelo público. Por outro lado, este trabalho argumenta que a telenovela brasileira contempla, para muito além da ficção, situações baseadas em fatos e pessoas reais, inaugurando uma espécie de antificção ${ }^{33}$ no formato. Seja como for, acentuamos a necessidade de delimitar um conceito de ficção que nos ajude a problematizar a telenovela brasileira:

A raiz do termo é latina, e tem como radical fict. Sua forma verbal, Fingere, é bastante sugestiva: significa modelar, criar, inventar. A ideia de criação de algo material associa-se, pois, à de invenção no sentido mais amplo, o que nos remete ao sentido fundamental de ficção: a ação ou o produto de um fingimento. Ficção deve ser definida, assim, como o ato ou efeito de trabalho imaginativo, idealizado, fingido; é tanto a ação de fantasiar quanto as produções que decorrem dela. (Bulhões, 2009, p. 17)

Para Moisés (2004, p. 188), “a ficção é sinônimo de imaginação ou invenção, encerra o próprio conceito de literatura". A origem latina fingere remete à ideia de fingir, imaginar, compor. Com efeito, a telenovela, enquanto forma de composição narrativa, provoca uma espécie de leitura fictivizante, um reconhecimento de que suas histórias são ficcionais e de que os atores estão, na verdade, fingindo ser outras pessoas. A propósito, Nichols (2007, p. 68) pontua que "mesmo as mais extravagantes das ficções evidencia a cultura que a produziu e reproduz a aparências das pessoas que fazem parte dela" e, dessa forma, conclui que todo

33 Sublinhamos que o prefixo anti quer dizer "oposição", "contra", " o oposto de " e combinado ao conceito de ficção significa "não-ficção", que descontrói a estrutura narrativa ficcional das telenovelas. 
filme, ficcional ou não, é um documentário e complementa: "um documentário é um tratamento criativo da realidade, não uma transcrição fiel dela". Admite-se, portanto, que as fronteiras entre a ficção e a não ficção são complexas de se estabelecer, pois, assim como a ficção extrai elementos da realidade, a não ficção é uma representação de uma realidade criada ou, em outros termos, é difícil conceber uma ficção "pura" onde tudo o que está presente na narrativa é resultado de uma invenção sem qualquer conexão com o real ou que um documentário é a representação fiel de um fato histórico sem qualquer interferência criativa por parte de seus realizadores.

Tal caráter de indissociabilidade entre a transfiguração de real está, aliás,no cerne de um importante conceito afim ao de ficção,o de imaginário o qual pode ser definido como a faculdade mental de produzir imagens que são elaboradas sempre com o apoio da realidade visível. (Bulhões (2009, p. 23).

E esta realidade visível irrompe na ficção de maneira mais enfatizada, conforme já pontuamos anteriormente, a partir da novela O Clone, em 2001. Deve-se ressalvar, no entanto, que esta relação entre o ficcional e o factual, em certa medida, esteve presente em outras obras anteriores como quando os senadores Eduardo Suplicy e Benedita da Silva comparecem a um velório de um político pertencente ao campo da ficção em o Rei do Gado (1996) ou quando o ator Flávio Silvino, vitimado de um acidente de carro, fica paraplégico e, com sérios problemas na fala, interpreta um personagem que , assim como ele, sofre destas limitações em Por Amor (1997). De qualquer maneira, estas misturas ou incursões do factual na narrativa da telenovela eram eventuais, ao contrário das novelas híbridas, nas quais as incursões de elementos de realidade foram acentuadas tornando-se frequentes e explícitas.

Em $O$ Clone, por exemplo, ficção e realidade combinam-se em prol de uma campanha de utilidade pública. Parentes e pessoas, vítimas das drogas, entram em cena para registrar seus depoimentos. Para resguardar suas imagens e para diferenciá-los dos personagens ficcionais, a autora, Glória Perez, orientou os diretores da novela para utilizarem enquadramentos fechados em superclose ou planos de detalhe para não identificar os entrevistados, que tinham medo de se mostrar em função do preconceito da sociedade. Os depoimentos reais eram inseridos na novela logo após a aparição dos dependentes químicos da ficção e, mais, o conteúdo desses depoimentos servia de inspiração para a autora recriar, na ficção, os dramas vividos pelos depoentes: 
Em primeiro lugar, eu achei que devia falar sobre a droga porque era o problema do momento, eu percebi que as pessoas ou tinham em casa alguém com a dependência química ou elas viviam com esse fantasma rondando, morrendo de medo que um filho ou que alguém de sua família se envolvesse nisso. Eu achei que era hora de falar sobre isso. Mas daí eu comecei a pensar como é que eu ia abordar este assunto. Eu já tinha escutado todo mundo falar sobre dependente, a polícia falava, o sociólogo falava, o psicólogo falava, mas a gente não escutava a voz deles. Eu comecei a conversar com alguns e resolvi fazer a campanha só do ponto de vista deles até pra não ser moralista, não ficar assim dividida entre uma série de tendências da psicologia, da psicanálise que começam a te dizer não é por aqui, o tratamento é por aqui , a pessoa se droga por isso ou por aquilo outro. Eu achei que a coisa mais real seria deixar que eles próprios falassem de si, nada seria mais forte nem mais eficiente do que isso. Então o que eu fiz? Procurei nas clínicas, fui até as clínicas, esse foi um trabalho que eu fiz pessoalmente. Nós gravamos, eu fazia a entrevista com as pessoas, elas gravavam tipo uma hora de entrevista e depois eu mesma ia pra edição e junto com o editor editava essa entrevista, escolhia os trechos que deviam ir ao ar de cada entrevista. Geralmente eu buscava escolher trechos que tinham a ver com as situações que os personagens estavam vivendo no momento e criava também as situações evidentemente a partir dos relatos. E depois de entrevistar os dependentes, como eu vi que toda a família se envolvia naquele processo, seja de desestruturação, ou seja, também na tentativa de reconstruir os laços familiares quando ele entrava em tratamento, eu resolvi entrevistar também os pais e os familiares. Então, por exemplo, a cena em que a Maysa sobe o morro pra pagar a dívida da Mel, os pais contavam isso, então eu fiz ela subindo e aí escolhia depois os depoimentos onde pais ou mães reais contavam o que era essa sensação de subir no morro pra pagar resgate de um filho. Isso tudo eu fiz pessoalmente, todos os depoimentos, eu tenho todas as fitas aqui na minha casa, evidentemente com câmera, e escolhi essa linguagem de só mostrar olhos, bocas e tudo porque eles próprios não queriam se identificar e acabou que eu acho que ficou bem mais forte de que se tivessem mostrado o rosto. E também teve uma coisa interessante: eles tinham medo de se identificar por causa do medo, do preconceito, inclusive. Mesmo assim eram identificáveis, mesmo do jeito como foi gravado, eles foram reconhecidos na rua e eu fiquei muito compensada, muito feliz porque, quando passou a primeira vez, passaram os primeiros depoimentos, eu vi que se poderia identificá-los. Apesar de ter optado por essa linguagem, fiquei com muito medo de que isso trouxesse algum prejuízo pra eles, mas quando eu voltei lá na clínica pra próxima gravação, estavam todos muito felizes porque foram procurados por familiares que estavam afastados há muito tempo, pessoas na rua, pros que estavam no serviço de ambulatório que já andavam na rua e tudo, vieram se solidarizar dizendo 'força, você vai conseguir' e acabou que essa experiência de trazê-los pra novela fez com que eles sentissem uma corrente muito positiva de apoio, de incentivo a continuarem a se submeter ao tratamento. ${ }^{34}$

Enquadrados em planos distintos dos personagens ficcionais, os depoentes olhavam diretamente para a câmera, uma das convenções formais do gênero documentário ou de uma

\footnotetext{
${ }^{34}$ PEREZ, Glória. Palestra proferida no I Encontro Nacional Obitel em São Paulo, 28 nov. 2007.
} 
entrevista de noticiário, mas nada comum em uma obra de ficção. Com efeito, é possível atribuir uma leitura documentarizante (Odin, 1984), identificando no nível da imagem uma estrutura estilística típica dos documentários:

(...) direcionamento para o cameraman (as pessoas filmadas olham para o câmera, interpelam-no) (...) A função desse conjunto de figuras é clara: marcar na própria estrutura do filme a existência real do cameraman; fazer o espectador saber que o cameran é tomado como enunciador real.(Odin, 1984, p. 06)

A leitura documentarizante propõe figuras estilísticas que estimulam o leitor a construir e perceber a presença real de um enunciador, como foco embaçado, imagens trêmulas, golpes de zoom, longos planos-sequência e iluminação deficiente, entre outros. No nível do som, timbre específico do som direto, e o olhar das pessoas diretamente para a câmera. A referida leitura pressupõe um leitor/receptor ativo que "constrói as imagem do enunciador, pressupondo a realidade desse enunciador (...) Assim, o que estabelece a leitura documentarizante é a realidade pressuposta do enunciador" (Odin, 1984, p. 03) e propõe um sistema de oposições entre a leitura fictivizante e documentarizante:

\begin{tabular}{|l|l|}
\hline Leitura fictivizante & Leitura documentarizante \\
\hline $\begin{array}{l}\text { O leitor recusa a construção de um } \\
\text { "eu origem" }\end{array}$ & $\begin{array}{l}\text { O leitor constrói um enunciador pressuposto } \\
\text { real }\end{array}$ \\
\hline
\end{tabular}

Na leitura fictivizante, parece haver uma recusa, por parte do receptor, de construir um "eu-origem" real. Desta forma, é plausível afirmar que, na ficção, podemos pontuar características que lhe são próprias, contrárias à leitura documentarizante: como imagens enquadradas em planos padronizados, sem tremulações, cortes secos, poucos planos sequência, sons limpos e sem interferências próprias do som direto e uma regra básica: o ator jamais olha para câmera.

Pode-se observar que essa relação entre a realidade e ficção é de mão dupla: do mesmo modo que elementos do real "entram" na ficção, a ficção "invade" a realidade: no último capítulo de $O$ Clone, uma personagem da ficção, $\mathrm{Mel}$ (Débora Falabela), é enquadrada no mesmo plano - superclose ou de detalhe que deixa a vista somente a boca, as mãos,parte da face, mantendo em sigilo a identidade dos entrevistados - em que os personagens da vida 
real apareceram em todo o período de exibição dessa novela.

Isso aí foi um opção minha de fazer que no último capítulo a Mel aparecesse como um deles, realmente como eles apareceram durante a trama inteira, dando seus depoimentos, isto estava escrito que teria que ser gravado assim, porque é um movimento duplo, a realidade entrou na ficção com eles e depois a personagem da ficção entra de certa forma na realidade afirma Glória Perez. ${ }^{35}$

Evidencia-se, assim, uma forte conexão dessa obra de ficção com elementos da realidade, dois âmbitos distintos que se retroalimentam, se misturam e acabam por consolidar o caráter híbrido da telenovela. Combinar fatos da ficção com a não-ficção é um recurso muito utilizado das telenovelas brasileiras, sobretudo nas de Glória Perez, especialista em combinar o jornalismo com a ficção:

Embora pareça ficção, o tema da clonagem humana ultrapassou as fronteiras das comunidades científicas e já ganhou as ruas. A clonagem animal já não é mais nenhum espanto, desde o advento da ovelha Dolly, em 1998. Coincidentemente, o cientista italiano Salvatore Antinori anunciou há pouco tempo que fará o primeiro clone humano em novembro (2001), um mês após a estreia da novela. Terá sido uma profecia da autora? Glória lembra que Barriga de Aluguel, apesar de exibida somente sete anos após ser escrita, foi esboçada a partir de um artigo que ela leu sobre a possibilidade de uma mulher gerar o filho de outra. Na fase de pesquisas para a história, ainda em 1985, surpreendeu-se com a descoberta de que a experiência já era feita em larga escala, inclusive em uma clínica de São Paulo.36

\subsubsection{Telenovela e Documentário}

O reconhecimento da antificção na telenovela e seu constante processo de hibridação entre elementos narrativos ficcionais e factuais implica formularmos uma questão nos seguintes termos: ao trazer elementos narrativos que extrapolam o campo da ficção - como por exemplo pessoas "reais" contracenando com atores da ficção e a inserção de acontecimentos noticiados em jornais de grande circulação - a telenovela brasileira aproximase do gênero documentário, consagrado pelo cinema, ou cumpre uma função parecida com as dos noticiários de televisão que visam informar a população sobre assuntos factuais? Ou, em

\footnotetext{
${ }^{35}$ PEREZ, Glória. Entrevista concedida ao autor. Curitiba. 30 junho, 2003.

36 Por Lilian Arruda, assessora de imprensa de "O Clone".
} 
outros termos, em que medida é possível executar uma leitura documentarizante nas telenovelas?

A respeito do gênero documentário, Nichols (2007, p. 47) nota que:

A definição de "documentário" não é mais fácil do que a de "amor" ou de "cultura". Seu significado não pode ser reduzido a um verbete de dicionário, como "temperatura" ou "sal de cozinha". Não é uma definição completa em sim mesma, que possa ser abarcada por um enunciado que, no caso do "sal de cozinha", por exemplo, diga tratar-se de composto químico de um átomo de sódio e um de cloro (NaCL). A definição de "documentário" é sempre relativa e comparativa. Assim como amor adquire significado em comparação com indiferença ou ódio, e cultura adquire significado quando contrastada com barbárie ou caos, o documentário define-se pelo contraste com filme de ficção ou filme experimental de vanguarda.

A postura de Nichols ao definir o gênero é corroborada por Ramos (2008, p. 22):

Em nossa abordagem, o trabalho de definição do documentário é conceitual. Estamos trabalhando com ferramentas analíticas que têm por trás de si uma realidade histórica. Não se trata aqui de estabelecermos uma morfologia do documentário, com a mesma metodologia que cerca, por exemplo, definições das ciências naturais. Diferenças entre documentário e ficção, certamente, não são da mesma natureza das que existem entre répteis e mamíferos.

Quer dizer, os limites e fronteiras que separam a ficção do documentário são tênues e complexos, até porque "alguns outros elementos estilísticos da narrativa documental são comuns com a ficção", ressalta Ramos (2008, p. 24). Entre esses elementos estão a encenação e a utilização de personagens.

Não resta dúvida de que a encenação representa uma das características centrais da narrativa ficcional, bastante comum no teatro, no cinema ficcional e, em particular, na telenovela. O recurso da encenação é utilizado pelos documentaristas em situações nas quais não foi possível o registro do exato momento em que o fato histórico ocorreu. Do mesmo modo que a ficção, o documentário também trabalha com a ideia de personagens: "se a narrativa ficcional se utiliza basicamente de atores para encarnar personagens, a narrativa documentária prefere trabalhar os próprios corpos que encarnam as personalidades do mundo, ou utiliza-se de pessoas que experimentaram de modo próximo o universo mostrado" (Ramos, 2008, p. 26). A propósito, personagem também é um termo utilizado na forma de jargão pelos jornalistas. Ao compor uma narrativa na forma de reportagem, os jornalistas costumam tratar 
os entrevistados ou pessoas retratadas na matéria como "personagem". Nessa perspectiva, a complexidade de se vislumbrar claras fonteiras entre o documentário e a ficção é reforçada. Por definição, personagem é um termo que se refere a "seres fictícios construídos à imagem e semelhança dos seres humanos: se estes são pessoas reais, aqueles são 'pessoas“ imaginárias", ensina Massaud (2004, p. 348). Dito de outro modo, o fato de se tratar como personagem pessoas "reais" retratadas em uma reportagem ou entre outras instâncias narrativas que elegem, a priori, o "real" como elemento básico de enunciação indica a possibilidade constante de se estabelecer diálogos entre o campo ficcional e o campo documentário, flexibilizando, assim, os limítrofes de suas fronteiras. "O fato de as fronteiras do documentário serem flexíveis não implica sua inexistência, nem retira o significado das áreas que delimitam”, enfatiza Ramos (2008, p. 49). Dentre outras narrativas que estabelecem diálogos frutíferos com o documentário, Ramos destaca quatro campos fronteiriços: o docudrama, o telejornalismo ou "atualidades", a publicidade e o cinema experimental; videoarte. Para o autor, docudrama não se configura como documentário porque, embora seja baseado em fatos históricos, ele possui todas as características de uma narrativa ficcional e, portanto, não enuncia como os documentários. Em relação às reportagens, Ramos (2008, p. 58) esclarece que, no documentário, há um espaço mais denso para a expressão do viés autoral, geralmente ausente na reportagem. Em outros termos, no documentário há uma articulação discursiva mais trabalhada. Enquanto o documentário está muito mais ligado a uma ideia de narrativa fílmica, a reportagem , ao contrário, não tem nada em comum com o filme, mas com outro formato enunciativo: a de programa de televisão que se utiliza de um âncora - figura ausente nos documentários - e de repórteres.

Em relação à propaganda, Ramos afirma que o filme Tiros em Columbine $^{37}$, por exemplo, para alguns é uma mera propaganda antiarmamentista, enquanto para outros é um documentário que retrata a indústria de armas norte-americana.

Na ética que norteia o documentário clássico, não há contradição em se fazer propaganda desde que as asserções estejam dentro do campo ideológico considerado positivo pelo sujeito que enuncia. Tanto no Ince brasileiro como no documentário inglês, a função do documentário é fazer propaganda das boas ideias (construir fossas secas, preservar alimentos, promover a cultura popular, divulgar a ciência) ou das boas causas (vender produtos do império

37 Realizado em 2002 e dirigido por Michael Moore, o filme retrata o massacre do Instituto Columbine (ocorrido em 20/04/1999, no Colorado, onde dois adolescentes atiraram em professores e estudantes) abordando a violências dos Estados Unidos e a publicidade de armas de fogo. 
britânico, enaltecer sua capacidade produtiva, promover a educação cívica para a democracia, glorificar as grandes figuras da história, criar uma identidade nacional). Não existe, portanto, contradição entre proposta documentarista e propaganda dentro do universo clássico e da ética educativa. (Ramos, 2008, p. 62)

Por fim, o autor problematiza a questão se uma instalação de videoarte, que estabeleça asserções sobre o mundo, pode ser considerada documentário. Sem se comprometer com as complexidades teóricas que esta discussão poderia provocar no campo do documentário, Ramos nota que reconhecer estas exposições como documentário seria abrir demais o campo, mas reconhece as influências que a arte de vanguarda provocou na tradição documentária.

Assim como o documentário dialoga com outras instâncias narrativas - docudrama, reportagens, publicidade e vídeos experimentais, a telenovela brasileira, em evidente sintonia com questões históricas, políticas e sociais, também estabelece, em certa medida, relações dialógicas com o docudrama, na medida em que parte para uma narrativa de antificção, ao trazer personagens e assuntos "reais" para suas tramas; com as reportagens de televisão quando pauta as histórias da ficção ou quando fornece temas para serem tratados nos telejornais, como já vimos anteriormente; e com a propaganda através das inserções de merchandising social. A esse respeito, Trindade (1999) ${ }^{38}$ afirma que "no plano conceitual o merchandising social está para a propaganda, assim como a publicidade está para o merchandising comercial". E também observa que "a publicidade está associada à difusão e ao estímulo do consumo e a propaganda está associada à difusão e divulgação de ideias"39. Segundo o autor, desde Beto Rockfeller (Tupi, 1968), são comuns as inserções de produtos comerciais que se agregam às cenas como se fizessem parte do cotidiano dos personagens. Nesta novela, o protagonista, depois de abusar das bebidas, tomava uma antiácido da marca Alka Seltzer da Bayer. Também se tornou célebre a aparição das calças Staroup na Novela Dancin Days (Globo, 1978) e da Ustop na novela Água Viva (Globo, 1980). Enquanto o merchandising comercial se consolidou na década de 1980, o merchandising social se estabeleceu de vez na década de 1990. Ambas as formas de merchandising estão institucionalizadas pela indústria televisiva. As ações de merchandising comercial são divulgadas nos créditos finais das novelas anunciando que, naquele capítulo, houve inserções

38 Ver TRINDADE, Eneus. Merchandising em telenovela: a estrutura de um discurso para o consumo. Disponível em :http://www.portal-rp.com.br/bibliotecavirtual/outrasareas/publicidadeepropaganda/0080.htm acesso: 04/04/2010.

39 idem. 
comerciais da marca de carro Kia, do banco Itaú ou dos cosméticos O Boticário, garantindo boa parte da receita das novelas, ao passo que as ações de merchandising social são divulgadas em relatórios anuais (tabela 2).

Pelo exposto, notamos que a telenovela estabelece diálogos mais evidentes com outras formas narrativas do que propriamente com o documentário, ao contrário do que pensávamos anteriormente. Isto porque, na telenovela, não há nem a intenção, nem o objetivo de enfatizar o campo estilístico do documentário por parte do autor:

O documentário, antes de tudo, é definido pela intenção de seu autor de fazer um documentário (intenção social, manifesta na indexação da obra, conforme percebida pelo espectador). Podemos, igualmente, destacar como próprios à narrativa documentária: presença de locução (voz over), presença de entrevistas e depoimentos, utilização de imagens de arquivo, rara utilização de atores profissionais (não existe um star system estruturando o campo documentário), intensidade particular da dimensão da tomada. Procedimentos como câmera na mão, imagem tremida, improvisação, utilização de roteiros abertos, ênfase na indeterminação da tomada pertencem ao campo estilístico do documentário, embora não exclusivamente. (Ramos, 2008, p. 25)

De fato, a intenção de qualquer autor de telenovela é a de produzir uma obra de ficção e de entretenimento. $\mathrm{O}$ espectador, de antemão, já sabe que se trata de uma narrativa de ficção do mesmo modo de que um espectador de documentário já vai às salas de exibição sabendo de que se trata de uma obra audiovisual que pertence ao campo do documentário. Mas o que dizer das telenovelas que trabalham com entrevistas, depoimentos, não atores ou autores não profissionais (a exemplo de Páginas da Vida onde jornaleiros, chaveiros, porteiros e outros típicos moradores do Leblon apareceram na trama representando eles mesmos e com seus próprios nomes) ou que, vez ou outra, utilizam o recurso do voz over?

$\mathrm{Na}$ tentativa de dar conta desta resposta, avançamos na hipótese de que a chave de compreensão deste fenômeno reside não no documentário, mas na investigação de um outro gênero ainda pouco estudado pela comunidade acadêmica: o docudrama. Assim como a telenovela, o docudrama - ao contrário do documentário - elege o melodrama como um dos principais ingredientes de enunciação e

The docudrama did not eliminate the documentary but when comparing the two forms, docudramas generally place more emphasis on personality and narrative. One continuing problem with this form is obtaining the appropriate balance between accuracy and fairness, on the hand, and dramatic embellishment on other. (Hoffer, 1999, p. 65) 


\subsubsection{Telenovela e Docudrama}

O melodrama representa um dos ingredientes básicos do docudrama e da telenovela. Desse modo, esta investigação busca pontuar características convencionais deste gênero através de uma quadro teórico sedimentado nos estudos propostos por Jean-Marie Thomasseau (2005), Marlyse Meyer (1996), Peter Brooks (1995) e Jesús Martín-Barbero (2004).

Para Thomasseau (2005, p. 06):

de maneira geral o melodrama, inalteradamente, apresenta a luta entre o bem e o mal absolutos, busca ser ao mesmo tempo universal e quotidiano, procurando comover o público através de uma estética moralizante que corresponde a códigos preestabelecidos. Sua trama também é de certa forma imutável; o vilão acaba sempre desmascarado pelo herói, o bem sempre vence o mal, e assim a virtude é sempre premiada e o crime sempre punido.

Peter Brooks, em The Meladromatic Imagination (1995), apresenta uma ampla análise do melodrama nas obras de dois renomados novelistas: Balzac e Henry James. Brooks alerta para o fato da difícil conceituação do termo melodrama, sem que isto ocasione em reducionismos. Entretanto, apresenta algumas características do gênero muito pontuais para esta investigação: forte apelo ao sentimentalismo, polarização moral, perseguição do bem, o triunfo da virtude no final da história, vilões fortemente demarcados, expressões extravagantes, conspirações misteriosas, entre outras. (Brooks, 1995, p. 11).

Assim como Brooks, Thomasseau (2005, p. 9) alerta para a difícil conceituação do termo:

A palavra melodrama, com efeito, traz ao pensamento a noção de um drama exagerado e lacrimejante, povoado de heróis falastrões derretendo-se em inutilidades sentimentais ante infelizes vítimas perseguidas por ignóbeis vilões, numa ação inverossímil e precipitada que embaralha todas as regras da arte e do bom senso, e que termina sempre com o triunfo dos bons sobre os maus, da virtude sobre o vício. Este esquema, se não é inteiramente falso, é por demais simplificador. 
A autora Glória Perez ${ }^{40}$ ressalta o caráter melodramático da telenovela ao afirmar que busca trabalhar com sentimentos universais. Neste sentido, a telenovela não esconde e nem pretende negar sua matriz folhetinesca e dramática, em que pesem seus consideráveis experimentos acerca de uma renovação do formato. A autora afirma, também, que a telenovela, provavelmente em razão de seu forte apelo popular, muitas vezes é alvo de severas críticas, como se fosse um produto mercadológico e acadêmico de menor valor.

Nesse sentido, Thomasseau acentua que esta visão deturpada por parte de críticos teóricos não tem fundamento, uma vez que estes mesmos críticos não sabem explicar os sucessos estrondosos alcançados pelo gênero. E lança uma hipótese: a de que o melodrama possui este caráter pejorativo em função de seu forte apelo popular ou popularesco.

Assim como Thomaseau, Meyer (1996, p. 57) observa o caráter pejorativo e popular geralmente creditado ao melodrama:

Os grandes gêneros populares do século XIX engendraram todo um campo semântico intercambiável e de carga altamente pejorativa. Melodrama, melodramático, folhetim, folhetinesco conotando previsíveis e redundantes narrativas, sentimentalismo, pieguice, lágrimas, emoções baratas, suspenses e reviravoltas, linguagem retórica e chapada, personagens e situações estereotipadas, etc.

Por outro lado, Jesús Martin-Barbero (2003, p. 183) nos lembra que as classes populares só tiveram acesso à literatura através do folhetim - primeiro tipo de texto escrito popular de massa - e que representa o resultado de uma fusão do ato de escrever, da figura do escritor e a do jornalista. Deste modo, é possível observar que a relação entre o factual (jornalismo) e ficcional esteve presente desde a origem da matriz narrativa fundamental da telenovela.

Barbero (2004) afirma que, exemplificando com a telenovela colombiana da década de 80 , as telenovelas latino-americanas estão abertas aos movimentos da atualidade social, se afastando das relações tradicionais do bem e do mal propostas pelo melodrama para se aproximar cada vez mais da vida cotidiana dos países.

$\mathrm{Na}$ América Latina o melodrama resultou em algo mais do que um gênero

40.I Encontro Nacional OBITEL - Observatorio Iberoamericano de la ficción televisiva - "A Pesquisa da Ficção Televisiva no Brasil", organizado pelo Centro de Estudos de Telenovela - CTVN - da Escola de Comunicações e Artes da Universidade de São Paulo e Globo Universidade, realizado nos dias 26, 27 e 28 de novembro de 2007. 
dramático, ou seja resultou em uma matriz cultural que alimenta o reconhecimento popular na cultura de massa, território-chave para estudar a não-simultaneidade do contemporâneo como chave das mestiçagens que somos feitos. (2004, p. 151)

Como vimos, o caráter híbrido da telenovela contemporânea mostra-se cada vez mais evidente através da forte relação entre a realidade e a ficção, razão pela qual estudos acerca do docudrama representam uma importante estratégia de compreensão das novelas atuais e é o que passaremos a discutir a seguir investigando os mecanismos de funcionamento do docudrama, aplicando-os, posteriormente, na telenovela. A pergunta que se faz neste momento é a seguinte: assim como Roger Odin pensou numa proposta de leitura de documentários que ele cunhou de leitura documentarizante, é possível vislumbrarmos uma proposta de leituras especificamente de docudramas ou, em outros termos, em uma leitura docudramentarizante? No capítulo seguinte vamos tratar de esclarecer o que é docudrama. 


\section{Capítulo 2 \\ Afinal, o que é docudrama?}

Assim como os documentários, os docudramas visam à representação de fatos necessariamente "reais" e nunca é demais sublinhar que a ideia de recriar eventos reais é mais antiga que o próprio cinema. A fotografia já era encarada como uma importante mediação tecnológica de registro do real e "aparece assim como uma referência analógica válida para a história". Desta concepção da fotografia como inocente, transparente, simples traço do real, emana sua utilização como documento". (Leutrat, 1995, p. 28). A fotografia funciona como um referente ${ }^{41}$ : arquiva traços indiciais da realidade. A priori, o que a fotografia registrou, de fato, aconteceu. Mesmo na era pré-fotográfica, o homem buscava registrar o que percebia através da pintura, na qual hábitos, costumes, registros de família eram retratados e que servem, até hoje, como documentos históricos e testemunhas de uma época. Com o surgimento das imagens em movimento (cinema) no século XIX, o registro do "real" passou a ser feito por essa nova modalidade de mediação de registro de imagens. Em 1898, os fatos de grande relevância como guerras, batalhas, dos quais as câmeras fotográficas não tinham registrado imagens, foram recriados. D.W. Griffith e outros importantes diretores de Hollywood se interessaram nos anos vinte 20 a reconstituir eventos históricos e bíblicos. E é exatamente esse interesse em reproduzir a história em imagens que, anos depois, a cinematografia convencionou chamar de documentário. De outra parte, a ficção, ou criação de fatos imaginados, manifestou-se em diversas artes, tais como a literatura nos códigos escritos e, mais tarde, nas representações audiovisuais: no cinema e posteriormente na televisão. Como cultura de massa, a ficção obteve muito sucesso nos folhetins divulgados nos rodapés de jornais no século XIX. No Brasil, o folhetim fez carreira nas ondas do rádio com as radionovelas e chega à televisão, na década de 1950, com as telenovelas, que tanto sucesso ainda fazem entre os espectadores. Embora as fronteiras que delimitam as características da ficção com o "real” pareçam ser bem delimitadas, quer dizer, o ficcional é necessariamente algo imaginado e um documentário é uma forma de se representar o "real", a sustentação dessa máxima ganha fragilidade a partir do momento em que reconhecemos que a ficção, por mais extravagante que possa ser, sempre vai manifestar algo de uma realidade, nem que seja

41. Tradicionalmente, entendem-se por referente os objetos do mundo "real", que as palavras das línguas naturais designam. O termo objeto mostrou-se notoriamente insuficiente, por isso o referente foi chamado a cobrir também as qualidades, as ações, os acontecimentos reais; além disso, como o mundo "real" parece ainda por demais estreito, referente deve englobar também o mundo "imaginário". (Greimas \& Cortes, 1979, p. 377). 
uma indicialização de elementos da cultura que a produziu, conforme já discutiu Nichols (2007). Essa questão fica ainda mais complexa quando a ficção se mistura explicitamente com elementos da realidade.

Vale ressaltar que as discussões sobre a mistura da ficção com a não ficção remontam à época das atualidades reconstituídas ${ }^{42}$ do primeiro cinema. Para Costa (2005, p. 194):

\begin{abstract}
As atualidades reconstituídas eram uma mistura bastante particular de elementos ficcionais e de documentários que existiu até cerca de 1907. Nelas se misturavam filmagens de situações autênticas com reconstituições de situações em estúdios, locações naturais ou nos próprios locais dos acontecimentos, incluindo encenações, trucagens e maquetes parecidas com as utilizadas nas ficções. Sua aparição suscita algumas questões importantes, uma vez que o que se chamava de "atualidades" não corresponde exatamente ao que se designa hoje como "documentário".
\end{abstract}

Nichols (2007) sustenta a ideia de que todo filme é um documentário, na medida em que evidencia elementos da cultura e características de pessoas por ele representados. Afirma, também, que há dois tipos de documentários: um que classifica como documentários de satisfação de desejos e outro de documentários de representação social. No primeiro caso, estariam os filmes ficcionais e no segundo o que costumeiramente são nomeados de não ficção.

O autor nos alerta para o fato de que o documentário não é uma reprodução fiel da realidade, mas, sim, uma representação do mundo em que vivemos, mediado por um cineasta que exerce uma relação de poder e responsabilidade ética com a vida daqueles que são retratados no filme. "Os documentários podem representar o mundo histórico da mesma forma que um advogado representa os interesses de um cliente: colocam diante de nós a defesa de um determinado ponto de vista ou uma determinada interpretação das provas" (Nichols, 2007, p. 30). Com efeito, "o documentário reivindica uma abordagem do mundo histórico e a capacidade de intervenção nele, moldando a maneira pela qual o vemos".

42. Costa (2005, p.196) ressalta que a "historiografia tem diferenciado o termo "atualidades" de "atualidades reconstituídas" segundo a presença ou não de tomadas encenadas". Nas atualidades era possível se programar para um evento previsível, como um discurso político ou uma cerimônia familiar: "o termo atualidade designa uma forma particular de realismo, que não é nem exclusivamente ficcional, nem exclusivamente documentária, nem exclusivamente cinematográfica. É uma forma de representação que lida com um repertório de referências culturais amplas - compartilhado por mídias como os jornais, as revistas ilustradas, os folhetins, o teatro, o circo, o museu de cera, a feira, e a própria fotografia-, dramatizando o real de maneira espetacular" (Costa, 2005, p. 206). Já as atualidades reconstituídas interessavam-se por assuntos de grande apelo popular como execuções e rebeliões e pelos fatos imprevisíveis, tais como: catástrofes e crimes, o que, por vezes, tornava necessária a reconstituição através de encenações. 
(Nichols, 2007, p. 69)

De forma análoga, o docudrama também representa o mundo histórico e social e é potencialmente capaz de intervir nele, haja vista o número de foragidos na justiça que foram capturados pelas autoridades judiciais após as exibições em rede nacional do programa Linha Direta. Lipkin (1999) aponta o Docudrama como sendo um formato híbrido resultante da fusão entre documentário e drama, mais especificamente melodrama, no qual questões éticas e morais ganham destaque. Assim como o documentário, o docudrama busca reconstruir ou retratar fatos históricos ou sociais. Entretanto, enquanto o primeiro o faz de maneira objetiva e procura retratar os fatos tais como eles são, o segundo constrói o discurso em uma relação híbrida com o melodrama clássico, na qual questões humanas, familiares, sentimentais, condutas das personalidades, catarses são postas em destaque. Desse modo, “o docudrama, na qualidade de discurso que enuncia pela forma da narrativa clássica, deve trabalhar a história a fim de transformá-la em trama. A história em si não basta para o docudrama”. (Ramos, 2008, p. 53)

Antes de continuar na investigação das origens do docudrama e no estudo dos mecanismos de funcionamento desse modo de produção audiovisual, deve-se registrar a ausência quase absoluta de discussões teóricas sobre o tema no cinema brasileiro. Durante o percurso de construção desta investigação, notou-se um certo grau de resistência por parte dos pesquisadores e realizadores do cinema no Brasil em reconhecer o docudrama como um gênero que transita entre as convenções do documentário e da ficção. "Ficções históricas não são documentários, e creio ser possível chegarmos a um consenso sobre isso sem nos esforçarmos muito", afirma Fernão Ramos (2008, p. 51). Ramos cita algumas obras brasileiras, baseadas em fatos históricos, como $O$ que é isso companheiro (1997, Bruno Barreto), Guerra de Canudos (1997, Sérgio Rezende) e Lamarca (1994, Sérgio Rezende) para ilustrar seu pensamento. Se esses filmes não são documentários, são apenas ficção? Ou são obras que se aproximam de um docudrama? Esses questionamentos impõem limites à presente investigação, visto que nosso foco de investigação é a teledramaturgia e não o cinema. Consideramos, portanto, urgentes propostas de estudo que contemplem o docudrama no cinema brasileiro. 


\subsection{Docudrama: definição e antecedentes históricos.}

Segundo Rosenthal (1999), foi nos anos 30 que ocorreu um real desenvolvimento e expansão do docudrama, o qual pode ser dividido em quatro áreas de estudo: a. fact-fiction epic dos estúdios de Hollywood; b. experimentos com a escola inglesa de documentário nos anos trinta e quarenta; c. o docudrama na televisão britânica dos anos 60; d. o docudrama na televisão americana nos anos 70.

Um dos antecedentes do docudrama, tal como conhecemos hoje, é representado, segundo Corner (1999), pelos dramatized documentaries, uma espécie de documentário produzido exclusivamente para a televisão britânica, através da BBC, nos anos 50. A temática eram as mais diversas, passando por histórias de vandalismos, drogas, problemas da juventude, casamentos na terceira idade e prostituição, entre outros. Do início dos anos 60 até meados dos 70, a BBC produziu dramatized documentaries que retratavam os problemas políticos e sociais da época. Dentre essas produções, destacamos Cathy Come Home ${ }^{43}$, que se propôs a discutir a carência de moradia na sociedade britânica dos anos 60. Eram histórias baseadas em fatos reais e encenadas de maneira dramática. A direção de Cathy Come Home utilizou diversos recursos convencionais do documentário, como o uso de testemunhais de pessoas que vivenciaram os fatos, uso da estratégia do povo fala, imitando os recursos das reportagens de tevê. Para imprimir mais realismo às cenas, o diretor optou por utilizar, na direção, close-ups e longas sequências sem cortes. De forma análoga, a direção da novela $O$ Clone (Globo, 2001) utilizou enquadramentos mais fechados (close-ups) para preservar a identidade das pessoas reais que apareciam na trama. A novela Páginas da Vida (Globo, 2006), de Manoel Carlos, exibiu em todos os finais de capítulo relatos de pessoas anônimas e comuns, mostrando os dramas e dilemas de suas vidas. Em 2009-2010, Manoel Carlos repete a estratégia em Viver a Vida. Semelhante à obra anterior, depoimentos de pessoas reais são inseridos na edição relatando os dramas de pessoas reais, o modo como aprenderam a conviver com doenças crônicas como o vírus HIV ou como superaram problemas como a cura de uma doença ou a perda de um ente querido. Tal mistura de elementos da realidade com a ficção tem sido mais frequentemente observada nas obras de Glória Perez e Manoel Carlos e

43. Dirigido por Ken Loach. (Reino Unido, 1966). Neste filme, Loach fez história no Reino Unido mudando as políticas governamentais para as pessoas sem moradia. 
constitui uma das marcas das novelas híbridas, que trazem, para a ficção, elementos externos à narrativa, aproximando-se, em certa medida, do docudrama. Nunca é demais sublinhar que essa estratégia de os autores de novelas misturarem pessoas reais com elementos da ficção não representa nenhuma novidade na história da televisão, uma vez que tal componente narrativo, como vimos, já estava presente nos dramatized documentaries na televisão britânica desde os anos 60. Deve-se ressalvar, no entanto, que tal mistura, tal componente narrativo, irrompe na telenovela brasileira um certo grau de novidade, uma inovação que manifesta deliberadamente uma hibridação entre a ficcionalidade e a factualidade, entre o melodrama e o documentário ou, em última análise, uma aproximação com o docudrama.

Já nos Estados Unidos, durante a década de 1970, Buonanno (1993) nos chama a atenção para a existência de uma reality syndrome ou de uma TV Truth - Televisão verdade nas quais havia uma tendência em abordar escândalos sensacionalistas e reconstituições de biografias ou históricos de vida de celebridades, enquanto na Inglaterra da década de 1960, conforme já observamos, buscava-se reconstituir investigações políticas e sociais. Assim como Buonanno, Hoffer (1999) afirma que uma característica básica do docudrama da televisão estadunidense consiste em reconstruir e reencenar a biografia de pessoas famosas pelos seus feitos. Pelo exposto, notamos que a origem e desenvolvimento do gênero docudrama se deram na Inglaterra e Estados Unidos e, nesse sentido, Rosenthal44 acentua que o docudrama atualmente é o gênero mais popular das televisões estadunidense e britânica: "Whether you call them docudramas, dramadocs, fact-fiction dramas, or something even more exotic, one thing is clear: reality-based stories, taken from topical journalism, are the most popular drama genre on U.S. and British television today”. (Rosenthal, 1999, p. xiii)

Na América Latina, segundo Fuenzalida (2008), a origem massiva do docudrama começa no México, em 1986, com a produção da Televisa Mujer, Casos de La Vida Real. Com duração total de 70 minutos e de exibição verspertina, o programa apresentava três episódios baseados em dramas reais vivenciados por mulheres. Em 2000, ainda no México, mas através da TV Asteca, foi ao ar o docudrama Lo que Callamos las Mujeres (Sobre o que cala as mulheres). Desde 1993, em horário nobre e com grande audiência, a TVN chilena exibe Mea culpa, uma dramatização baseada em fatos reais de ex-deliquentes que

44. Alan Rosenthal é professor, editor dos livros Why Docudrama? Fact-fiction on film and TV e Writing, directing, and producing documentary films and vídeos. É documentarista ativo em Israel, Inglaterra e Estados Unidos. Seus filmes são exibidos com freqüência no Channel 4 na Inglaterra, na televisão israelita e na $\mathrm{ABC}$ nos Estados Unidos. 
demonstram arrependimentos de seus crimes.

O gênero ficional híbrido do docudrama cresceu nas últimas décadas nas telas da América Latina, alcançando (em ocasiões de realização cuidadosa) um grande audiência em horários nobres. Comprovações feitas por estudos de recepção mostram que os docudramas são interpretados como programas educativos por grande parte do público" (Fuenzalida, 2008, p. 161)

É importante mostrar que o Chile se apresenta como um dos grandes produtores de docudramas. Além dos já citados, destacam-se Mujer rompe el silencio (2004) e Histórias de Eva (2005). Dados consolidados do OBITEL indicam o Chile como o maior produtor do gênero entre os países que compõem a rede de pesquisa. Durante o triênio (2006, 2007 e 2008), o docudrama, em termos de títulos, representa $13 \%$ do total de estreias no Chile:

Tabela 4: Formatos de ficção nacional no Chile (média do triênio 2006, 2007 e 2008)

\begin{tabular}{|l|l|l|l|l|l|l|}
\hline & Títulos & $\%$ & $\begin{array}{l}\text { Capítulos ou } \\
\text { episódios }\end{array}$ & $\%$ & Horas & $\%$ \\
\hline Série & 38 & 34 & 1.482 & 35 & $796: 18$ & 31 \\
\hline Telenovela & 26 & 24 & 2.318 & 55 & $1390: 10$ & 54 \\
\hline Minissérie & 5 & 5 & 28 & 1 & $16: 31$ & 0,6 \\
\hline Telefilme & 27 & 24 & 147 & 3 & $140: 13$ & 5,4 \\
\hline Docudrama & 14 & 13 & 243 & 6 & $237: 03$ & 9 \\
\hline Total & 110 & 100 & 4.218 & 100 & $2.580: 15$ & 100 \\
\hline
\end{tabular}

Fonte de dados: anuários Obitel (2007, 2008 e 2009)

Vale destacar que todos os títulos de docudramas foram exibidos no horário nobre chileno: das $20 \mathrm{~h}$ às $24 \mathrm{~h}$. No Chile, o horário matutino é compreendido das $6 \mathrm{~h}$ às $12 \mathrm{~h}$; vespertino, das $12 \mathrm{~h}$ às $20 \mathrm{~h}$; e o noturno, das $24 \mathrm{~h}$ às $6 \mathrm{~h}$. Na tabela a seguir, compilamos dados de horários de exibição no triênio 2006, 2007 e 2008. Destaca-se o docudrama como uma das apostas centrais na televisão chilena no horário nobre: ele ocupa $18 \%$ da programação, aproximando-se das séries e telefilmes, com $22 \%$ cada um:

45. Também conhecido como $T V$ movie ou made for $T V$. Trata-se de um filme realizado exclusivamente para ser exibido na televisão. 
Tabela 5: Faixas de horário dos formatos nacionais no Chile (média do triênio 2006,2007 e 2008)

\begin{tabular}{|l|l|l|l|l|l|l|l|l|} 
& Manhã & $\%$ & Tarde & $\%$ & Horário nobre & $\%$ & Noite & $\%$ \\
\hline Série & 5 & 100 & 13 & 86 & 17 & 22 & 3 & 23 \\
\hline Telenovela & 0 & 0 & 1 & 7 & 25 & 33 & 0 & 0 \\
\hline Minissérie & 0 & 0 & 1 & 7 & 4 & 5 & 0 & 0 \\
\hline Telefilme & 0 & 0 & 0 & 0 & 17 & 22 & 10 & 77 \\
\hline Docudrama & 0 & 0 & 0 & 0 & 14 & 18 & 0 & 0 \\
\hline Total & 5 & 100 & 15 & 100 & 77 & 100 & 13 & 100 \\
\hline
\end{tabular}

Fonte de dados: anuários Obitel (2007,2008 e 2009)

Como é sabido, somente os programas com grande potencial de audiência ocupam o horário nobre nas emissões televisivas, o que confirma o docudrama como uma das principais apostas da TV Chilena. De acordo com a metodologia de pesquisa do Obitel que prevê, em cada anuário, os dez programas de ficção de maior audiência de cada país, o docudrama é destacado como gênero de sucesso no último triênio pesquisado, segundo dado do ObitelChile $^{46}$ : em 2006, o docudrama Mea Culpa ${ }^{47}$ ocupou o terceiro lugar da audiência (24,9 de rating) ficando atrás da telenovela Cómplices (26,5) e do outro docudrama El dia Menos pensado (26,2). A sinopse de Mea Culpa é resumida da seguinte forma:

Docudrama donde cada episodio recrea una dramatización, un hecho policial que termina con una entrevista real al delincuente detenido en la cárcel. El programa se caracteriza por la puesta en escena de corte dramático, donde los elementos de ficción están atenuados, ya que las historias son reales, los actores son desconocidos, y la amabientación y actuación reproducen una realidad alejada de efectismos cinematográficos. ${ }^{48}$

Em 2006, além de Mea Culpa e El dia Menos pensado, dois outros docudramas figuram entre os dez mais do Chile: Pecados Capitales (19,7 de rating) e Historias de Eva

46. Ver anuário Obitel 2007: Culturas Y mercados de la ficción televisiva en iberoamerica. Barcelona: Gedisa, 2007, p. 124-129.

47. Esse programa é considerado um dos maiores sucessos da TV chilena. Em 1995, os direitos do formato foram adquiridos pela Endemol, produtora holandesa responsável por comercializar diversos programas de sucesso pelo mundo como o Big Brother, exibido pela Globo, e Um Contra Cem e Topa ou Não Topa pelo SBT.

48. Idem p. 125 
(18,1 de rating). Pecados Capitales é baseado em histórias reais e, em cada episódio, atores desconhecidos interpretam personagens que se envolvem em tramas que têm como tema central os pecados capitais. "Historias de Eva é um docudrama inspirado en casos reales abordados en el programa El diario de Eva". ${ }^{49}$

Em 2007, o docudrama Mi verdad: mujeres en prisión está entre as dez maiores audiências do ano, segundo dados consolidados do Obitel-Chile ${ }^{50}$. Mi verdade: mujeres em prisión é:

Docudrama onde em cada capítulo uma mulher, que agora está na prisão, conta a uma entrevistadora (a advogada Carmen Glória Arroyo, que atua como juíza no programa diário La Jueza, transmitido pelo mesmo canal) a história de sua vida e do crime que a isolou da sociedade, enquanto são intercaladas dramatizações dos episódios que a levaram à prisão. São doze capítulos que narram histórias de doze mulheres diferentes ${ }^{51}$.

Em 2008, o docudrama El dia Menos pensado ocupa o primeiro lugar na audiência entre os dez programas de ficção mais destacados no ano, ultrapassando as telenovelas, séries e telefilmes. Este docudrama já havia ocupado o segundo lugar no ranking dos dez programas de estreia de ficção, em 2006. "El Dia Menos Pensado trata de fenômenos paranormais

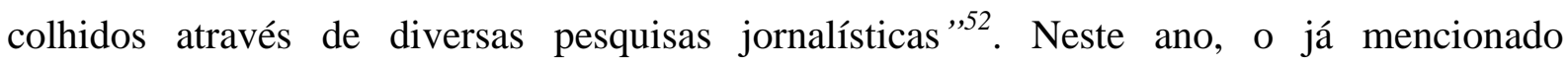
docudrama Mea Culpa volta a ocupar o terceiro lugar do ranking dos dez mais (com 19,0 de rating), ficando atrás da telenovela El Señor De La Querencia (19,3) e El Dia Menos Pensado (22,5).

Para Fuenzalida (2008, p. 162):

Do ponto de vista de conteúdos, o docudrama é um gênero híbrido, isto é, através da representação 'ficcional feita por atores, narra casos dramáticos de origem real'. São situações cotidianas 'limites ou extremas', que aconteceram com pessoas comuns, mas não são narradas no formato de documentário nem de reality show, mas sim de modo ficcionalizado e mais livre. Não se restringem exatamente ao caso referencial e ocorre a introdução de elementos ficcionais. A utilização de música para emocionar o relato é um elemento importante dessa maior liberdade narrativa.

49. Ibidem p. 128

50. Ver anuário Obitel 2008: Mercados Globais, histórias nacionais. Rio de Janeiro: Editora Globo: 2008, p.

121-145.

51. Idem pág. 135.

52. Ver anuário Obitel 2009: A ficção televisiva em países ibero-americanos: narrativas, formatos e publicidade. Rio de Janeiro: Editora Globo, 2009, p. 158-193. 
No Brasil, o programa de televisão que mais representava o gênero docudrama era o programa Linha Direta ${ }^{53}$, da TV Globo. Era exibido semanalmente às quintas-feiras na faixa horária após a novela principal. Com forte apelo popular, o programa reconstituía cenas de crimes não desvendados pelas autoridades e apelava para o público o reconhecimento dos assassinos, fornecendo um telefone para denúncia. Linha direta esteve no ar desde maio de 1999 e divulgou em seu site que foram capturados 412 criminosos54, cujos delitos, supostamente cometidos, foram reconstituídos através das informações presentes nos processos movidos judicialmente pelo Ministério Público. Em cada reconstituição, o apresentador reforçava a ideia de que o roteiro apresentado foi baseado nas informações das autoridades oficiais.

Nos filmes documentários de reconstituição, os créditos nos convidam a não considerar como enunciadores reais os atores de fato, mas o responsável pelo discurso, aquele que garante a autenticidade dos eventos relatados e das palavras pronunciadas. (Odin, 1984, p.7)

Em Linha Direta, somos convidados a torcer para que os criminosos sejam punidos e a ordem seja restabelecida. Esta é uma clássica forma do melodrama e, assim como os tradicionais documentários cinematográficos, cumpre uma função social e política no mundo histórico, ajudando a estampar na tela de tevê rostos de criminosos que devem prestar contas à sociedade. Esta fusão entre a ficção e o factual pode ser até mesmo observada nos créditos finais do programa Linha Direta, nos quais podemos observar que o referido programa é uma realização da Central Globo de Jornalismo em conjunto com a Central Globo de Produção, uma clara fusão entre departamentos de produção de notícias e de fícção. A Central Globo de Jornalismo (CGJ) é responsável pela produção dos telejornais em rede nacional e os locais, através das emissoras afiliadas. Dentre as responsabilidades desta central estão programas jornalísticos que são transmitidos há décadas como o Jornal Nacional, Globo Repórter e Fantástico, entre outros. A Central Globo de Produção (CGP) é considerado o maior centro de produção digital do mundo e é responsável pela produção dos programas de entretenimento, entre os quais a telenovela, programas de auditório, seriados e minisséries. Localizada no Projac ${ }^{55}$, a CGP é responsável por milhares de horas inéditas de produção

53. Linha Direta saiu do ar em 2008.

54. Fonte: site www.globo.com/linhadireta, acessado em 12/10/2007.

55. Inaugurado em 1995 e localizado no bairro de Jacarepaguá no Rio de Janeiro, o Projac (projeto Jacarepaguá) é o maior centro de produção audiovisual da América Latina. Conta com dez estúdios de gravação, sendo que 
nacional. Essa combinação entre as centrais de jornalismo e produção confirma o caráter híbrido de Linha Direta, que convoca repórteres e profissionais de produção que buscam assegurar a autenticidade dos fatos tratados e a produção das reconstituições de crimes encenados por atores. Essa tendência abrange não só a televisão brasileira, mas também a televisão mundial:

As television's generic system shows as increasing tendency toward hibridization and reflexiveness, this blurring is likely to continue, but so is public debate about programs that combine dramatic with journalistic values in relation to sensitive political and social themes. (Rosenthal, 1999, p. 45,).

Em seu último programa, no ar em 01/02/2008, a TV Globo publicou um comunicado nos seguintes termos:

\begin{abstract}
A respeito das manifestações de entidades ligadas aos Direitos Humanos pela continuidade do programa Linha Direta - por seu reconhecido interesse público-, informamos que a TV Globo passou a adotar o sistema de temporadas. Mesmo com êxito e importância comprovados, os programas têm sua exibição suspensa, passando por uma reavaliação para uma nova exibição futura. Agradecemos pelo reconhecimento e esperamos voltar em breve com uma nova versão de Linha Direta. Central Globo de Comunicação. Rio de Janeiro, 01 de fevereiro de 2008. ${ }^{56}$
\end{abstract}

Além de Linha Direta, a TV Globo investiu no gênero apresentando a reconstituição histórica de vida de personalidades ligadas ao campo musical. Nomes como Nara Leão, Tim Maia, Elis Regina, Renato Russo, Leandro, Mamonas Assassinas, Dolores Duran e Abelardo Barboza (Chacrinha), personalidades de destaque na história musical do Brasil, tiveram suas vidas reconstituídas no Programa Por Toda Minha Vida, com a dramatização biográfica de alguns momentos marcantes na vida destes artistas, somada a depoimentos de amigos e familiares, imagens de arquivo e fotografias. Observamos que, enquanto Linha Direta enfoca o vilão a ser punido, Por Toda Minha Vida enaltece a trajetória do herói ao reconstituir histórias de vida de artistas populares na música brasileira. Em Linha Direta, há uma clara distinção entre o "vilão"- criminosos, foragidos da justiça - e as vítimas e, em certa proporção, o programa cultua a tradição do folhetim melodramático que pune severamente o mal em prol do bem.

quatro são exclusivos para produção de telenovelas, além de mais de 160 mil metros quadrados de cidades cenográficas.

56. Fonte: http://redeglobo.globo.com/Linhadireta/0,26665,4625,00.html, acessado em 04/12/2009. 
Até o momento da realização desta pesquisa, o programa Por Toda Minha Vida teve onze episódios divididos em três temporadas: um piloto em 2006, três temporadas distribuídas pelos anos de 2007, 2008 e 2009, conforme ilustramos a seguir:

\begin{tabular}{|l|l|l|}
\hline $\mathrm{Nr}$ & Personalidade retratada & Exibição \\
\hline 01 & Elis Regina & $28 / 12 / 2006$ \\
\hline 02 & Leandro & $22 / 06 / 2007$ \\
\hline 03 & Renato Russo & $14 / 09 / 2007$ \\
\hline 04 & Nara Leão & $26 / 10 / 2007$ \\
\hline 05 & Tim Maia & $14 / 12 / 2007$ \\
\hline 06 & Mamonas Assassinas & $10 / 07 / 2008$ \\
\hline 07 & Dolores Durán & $17 / 07 / 2008$ \\
\hline 08 & Chacrinha & $20 / 07 / 2008$ \\
\hline 09 & Cazuza & $19 / 11 / 2009$ \\
\hline 10 & Claudinho & $26 / 11 / 2009$ \\
\hline 11 & Raul Seixas & $03 / 12 / 2009$ \\
\hline
\end{tabular}

Como é notável, Por Toda Minha Vida conduz o olhar do espectador para tomar personagens ou personalidades como enunciadores reais; os fatos dramatizados são baseados em arquivos de família, conferindo à produção um caráter biográfico. São celebridades reconhecidas pelos seus feitos no campo artístico, predominantemente musical, e que formaram uma legião de fãs em todo o Brasil. Os docudramas produzidos enfocam, para muito além da biografia desses artistas, as circunstâncias em que eles morreram que acabaram por provocar uma espécie de "comoção coletiva" nas pessoas que, de uma hora para outra, choraram por essas mortes como se fossem entes queridos da própria família e desejaram ir aos velórios e enterros para dar um último "adeus" aos seus ídolos. Das onze celebridades retratadas, duas (Mamonas Assassinas e Claudinho) tiveram mortes trágicas: acidente aéreo e de carro, respectivamente. Em ambos os casos, as produções enfatizaram a curta trajetória desses jovens, pobres e típicos moradores da periferia, que morreram precocemente no auge de suas carreiras. Já as mortes de Renato Russo e Cazuza foram motivadas por uma doença em comum: a aids que, na década de 1980, representava a morte rápida e certa diante das limitações da medicina e do preconceito estimulado pela total ignorância da população que acreditava ser essa uma doença exclusivamente de homossexuais. Outras personalidades 
foram vítimas de câncer (Leandro), overdose de drogas (Elis Regina), tumor cerebral (Nara Leão), edema pulmonar (Tim Maia), infarto fulminante (Dolores Duran) e parada cardíaca (Raul Seixas). Como se vê, a trajetória da vida dessas personalidades e as causas de suas mortes são assuntos potencialmente fortes para serem dramatizados em forma de docudrama. Como ilustração, a matéria jornalística intitulada de Tragédia merece tom folhetinesco ${ }^{57}$, assinada pelo jornalista Armando Antenore, no Jornal Folha de São Paulo, publicada em 10/03/1996, é sintomática:

Não é novela, já sabemos. A meteórica carreira dos Mamonas Assassinas
terminou tragicamente há uma semana. E as duas maiores redes brasileiras
de televisão optaram por retratar a realidade brutal, inverossímil, com um pé
no folhetim. Acertaram. Tanto a Globo quanto o SBT dedicaram os dias 3 e
4 à cobertura exaustiva do acidente. Preocuparam-se, claro, em dar as
informações essenciais - entender por que o avião caiu, acompanhar o
resgaste dos corpos, saber se a banda deixou músicas inéditas. Nesse sentido,
seguiram à risca a cartilha daquilo que se convencionou chamar de bom
jornalismo. Simultaneamente, porém, não desprezaram a faceta rodrigueana
do fato. Permitiram que o patético, o piegas, o dramático transbordassem
para o vídeo. Enxergaram a notícia também sob o prisma emocional das
telenovelas. Abraçaram o sensacionalismo, resmungarão os puristas. Que
respondam, então: há sensacionalismo quando se está lidando com o
absurdo, quando é a própria vida que exagera?

A qualidade de texto e de produção conferiu ao programa, em 2009, a indicação ao prêmio Emmy Internacional - espécie de Oscar da televisão americana - na categoria arte. Além do especial de Mamonas Assassinas, a TV Globo concorreu em mais quatro categorias: telenovela, com Caminho das Índias, minissérie (Maysa), infantil ( $O$ Natal do Menino Imperador) e comédia (Ó paí ó). Caminho das Índias recebeu o prêmio de melhor telenovela de 2009, a única produção de um país latino-americano a receber o prêmio. Países como Argentina e México não levaram nenhum prêmio, embora tenham inscrito diversas produções. Caminho das Índias chegou à final com duas novelas das Filipinas e uma da França.

O comprovado reconhecimento da qualidade dessas produções televisivas convocam discussões e pesquisas sobre quality television (televisão de qualidade), expressão utilizada pela primeira vez por estudos britânicos na década de 1980, tema ao qual pesquisadores, como Arlindo Machado, se dedicam na investigação:

57. Disponível em: http://www1.folha.uol.com.br/fsp/1996/3/10/tv_folha/2.html, acessado em 11/01/2010. 
Uma palavra-chave nas discussões mais recentes sobre televisão é qualidade. Alguns autores e alguns eventos nacionais ou internacionais instituíram, inclusive, o termo quality television (televisão de qualidade) para designar o novo foco de interesse. Eu particularmente não gosto dessa expressão, pois o acréscimo de um adjunto adnominal à palavra televisão produz uma discriminação que pode ser nociva à própria ideia que se quer defender. De uma forma geral, ninguém fala de "literatura de qualidade", nem de "cinema de qualidade", nem de "música de qualidade", uma vez que nos parece óbvio que só o que tem qualidade é verdadeiramente literatura, cinema e música. Por que deveria ser diferente com a televisão? Ademais, a adoção de uma expressão restritiva para designar uma certa modalidade de televisão poderia reforçar um equívoco já bastante disseminado, segundo a qual, "por natureza", não tem qualidades; daí a necessidade de caracterizar a qualidade em televisão como um "acréscimo", uma situação especial, uma espécie de desvio da norma. (Machado, 2000, p. 13)

O termo qualidade, segundo Machado, é escorregadio e se presta às mais diversas interpretações, tornando complexo o ato de se classificar determinados programas televisuais como sendo de "qualidade" e outros não. Duplamente complexa, é a tentativa de se estabelecer categorias de qualidade, conforme propõe Geoff Mulgan apud Machado (2000, p. 24). Mulgan enumera sete concepções do termo qualidade quando analisa a televisão: qualidade pode ser (1) um conceito puramente técnico ou capacidade de se aplicar os recursos da fotografia, da direção de arte, boa interpretação, etc; (2) a capacidade de detectar as demandas de audiência (análise de recepção) e da sociedade (análise de conjuntura) a fim de transformá-las em programas; (3) uma competência na busca do novo, explorando os recursos da linguagem em novas experiências estéticas; (4) promoção de aspectos pedagógicos e morais, criando programas educativos que visem à transmissão de valores; (5) capacidade de gerar mobilização social em tornos de temas de interesse coletivo; (6) programas que valorizem as diferenças, as minorias, os excluídos, em vez da integração nacional e estímulo ao consumo; e (7) diversidade: criação de fluxos de programação que permitam experimentações.

Sem a pretensão de nos prolongar nas discussões acerca do termo quality television, é notável como o docudrama é um gênero que está ganhando cada vez mais espaço de produção, principalmente nas emissões televisivas, figurando, como vimos, no primeiro lugar entre os dez programas de maior audiência no Chile e sendo indicado ao maior prêmio da televisão mundial: O Emmy internacional. Disso resulta a necessidade de se compreender os mecanismos de funcionamento desse gênero, ainda pouco investigado pela comunidade acadêmica. Nesse cenário, Rosenthal (1999) ressalta a dificuldade de se nomear o gênero: 
What is this hybrid form that floats uneasily between documentary and fiction? What is docudrama? There is, before all else, the difficulty of the name and the bewildering labeling. Docudrama. dramatic reconstruction. Faction. Reality-basead film. Murdofact. Fact-based drama. Biopic. (Rosenthal, 1999, p. xiv, grifo nosso)

Todavia, Rosenthal reconhece que o maior problema não reside em nomear o gênero, mas, sobretudo, em definir os parâmetros característicos do docudrama.

Em contraste, Javier Maqua ${ }^{58}$ (1992) aponta o docudrama como um conceito controvertido:

No se va hablar aqui de esa combinación de gêneros - documental y drama porque, entre otras cosas, documental e drama son gêneros que pertenecen a clasificaciones genéricas cerradas, completas y tan disímiles que ni siquiera se tocan". (...) Lo que en las práticas televisivas vemos casi siempre bautizado con el nombre de "docudrama" no es más que una mezcla, una reunión más o menos chapucera de gêneros diversos sin posible conjunción alguna y que ( en su momento nos detendremos en ello) amenaza con granguenar no solo el discurso televisivo, sino todos los discursos audiovisuales afines. (1992, p. 8)

Maqua prefere definir o docudrama como fronteras de la ficción, uma vez que para o autor o termo frontera dá uma noção mais adequada do fenômeno porque supõe a existência de um território, de geografias distintas e convergentes. Com efeito, para esse autor, o documentário pertence a um campo conceitual fechado já consolidado, do mesmo modo que o drama pertence a outro território. Todavia, nada impede que haja uma mistura entre essas fronteiras conceituais.

Esse embate entre Rosenthal (1999) e Maqua (1992) aponta uma dificuldade conceitual e territorial que o termo docudrama encontra na medida em que, ao combinar elementos convencionais do documentário com o melodrama, funde características de duas instâncias já delimitadas que, muitas vezes, não comunicam de forma clara e objetiva as fronteiras e as diferenças entre o documentário e docudrama. Entretanto, Rosenthal sinaliza uma pontual diferença entre os dois gêneros ao acentuar que o docudrama, fundamentalmente, assim como o melodrama, sugere uma moral da história com a consequente punição do mal (vilão) e exaltação do bem (herói).

\footnotetext{
${ }^{58}$ Javier Maqua é escritor e crítico cinematográfico na Espanha.
} 
As investigações acerca do docudrama estão longe de serem consensuais entre pesquisadores do audiovisual, o que dificulta uma compreensão mais precisa do gênero. Para Ramos (2008):

\begin{abstract}
A ausência de voz over/ locução, entrevistas, depoimentos, imagens de arquivo, o uso de atores profissionais, o fato de as peripécias serem complexas, articuladas em torno de reconhecimentos e reviravoltas, tudo isso aproxima o docudrama da estrutura típica da narrativa clássica ficcional, afastando-o do documentário. (Ramos, 2008, p. 51)
\end{abstract}

Ora, se a gênese do conceito docudrama está baseada numa relação híbrida entre as convenções formais do documentário e do melodrama, é bastante razoável concluir que o gênero dialoga, sim, com o documentário, uma vez que utiliza elementos geralmente atribuídos ao documentário como imagens de arquivo, entrevistas, etc, ao contrário do que aponta Ramos. Não fosse assim, como qual categoria de gênero poderíamos classificar o programa Linha Direta da TV Globo, no qual podemos observar tramas baseadas em fatos reais e que, na reconstituição, utiliza elementos clássicos da narrativa documentária, como entrevistas, imagens de arquivo de família em vhs, fotos, depoimentos de familiares e utilização de atores não conhecidos pelo grande público? Simplesmente como ficção baseada em fatos reais?

Diante dessa imprecisão conceitual, esta investigação adota como estratégia, para melhor compreender os mecanismos textuais do gênero, o estudo e reconhecimento de publicações anteriores que acabam por classificar determinados filmes e programas de televisão como docudramas. Lipkin (1999) define docudrama, exemplificando com os filmes JFK (1991), A Lista de Schindler (1993) e In the Name of the Father (1993). Tais filmes reconstituem os seguintes fatos históricos: assassinato do presidente norte-americano JFK, holocausto e atentado a bomba pelo IRA, respectivamente. O que há de comum entre essas obras é o fato de todas elas serem baseadas em fatos reais e misturarem elementos históricos com ficção, tomando como enunciadores reais personagens que foram assassinados: a exemplo de $J F K$ e a dizimação de centenas de judeus durante o holocausto (A Lista de Schindler) ou foram vítimas de erros judiciais (In the Name of the Father). Em outras palavras, há uma forte carga melodramática nessas obras:

Schindler`s list. In the name of the father, and in particular JFK iluminate the problems inherent in docudrama generally- with a moral perspectiv 
incorporated within its melodramatic narrative scrituture, docudrama strikes a moral pose free from the ethical concerns usually applicable when a documentary builds its positions from indexical imagery. (Lipkin, 1999, p. 371)

$J F K$ é um filme que conta a saga de um promotor, Jim Garrison (Kevin Costner), que dedica sua vida para investigar a morte do presidente JFK ocorrida na década de 1960. No início do filme, o espectador não sabe se assiste a um documentário ou uma obra de ficção, já que as primeiras cenas são arquivos de época, com imagens do presidente JFK em suas atuações políticas e familiares. Tudo é narrado com uma voz de locutor em off, típica dos documentários tradicionais. Entretanto, após a imagem da morte do presidente, a ficção entra em cena, mas sempre misturada com imagens de arquivo dos noticiários da época. Lipkin (1999) complementa:

JFK iliminate the problems inherent in docudrama generally - with a moral perspectiv incorporated within its melodramatic narrative structure, docudrama strikes a moral pose free from the ethical concerns usually applicable when a documemtary bilds its positions from indexical imagery. (....) As fictions, docudramas offer powerful, attracive arguments about actual subjects, depicting people, places, and events that exist or have existed. (Lipkin, 1999, p. 370)

A Lista de Schindler é baseado na história real de Oskar Schindler (Liam Neeson), membro do partido nazista que salvou a vida de mais de mil judeus durante o holocausto.

Schindler's List also features contrasting family settings and even more extremely contrasting father figures. Oskar Schindler and Amon Goeth are morally opposite surrogates of the same "family", the Jews of Kraków. Settings in this film also move throuhg a sucession of domestic environmentes: people are displaced from their original residences and forced to cram together by the dozens, first in reassigned ghetto apartmentes, then the Plaszgow camp barracks. Schindler`s factory provides an opportunity to survive the dangers of the guetto or the camp. Its imagery turns domestic. The factory manufactures pots and pans. Schindler eats at the table in a corner of his upstairs office, surrounded by houseplants. As a melodramatic icon, the factory stairwat figures prominently in the film when a woman comes to Schindler twice to beg him to take on her father and mother as workers. He stands up at the topo of the stairs, a backlit, smokeenshrouded figure of mystery, his life-granting power verified in a subsequente scene when the daughter stands across the street, watching unseen, Stella Dallas - like as her parentes arrive for work. (Lipkin, (1999, p. 175) 
Desse modo, o filme A lista de Schindler pode ser considerado um docudrama.

The conclusion of Schindler's List offers a final warranting of its docudramatic articulation by wedding the moral perespective conveyed throuh its narratives's melodrama with a sucession of documentary images and assertions (Lipkin, 1999, p. 377)

Em In the name of the father, acompanhamos a história verdadeira de Gerry Conolon (Daniel Day-Lewis), um jovem fanfarrão dos anos 70 que acaba por ser forçado a confessar um atentado a bomba e é condenado à prisão perpétua junto com seu pai Giuseppe (Pete Postlethwaite). Gerry decide provar sua inocência e expor um dos mais vergonhosos acontecimentos da história mundial.

O docudrama tende a transformar os fatos em tramas e, com efeito, apresenta uma forte tendência de se reproduzir um discurso moralizante com a exaltação de heróis e a consequente punição do mal nos moldes do melodrama.

De maneira geral o melodrama, inalteradamente, apresenta a luta entre o bem e o mal absolutos, busca ser ao mesmo tempo universal e quotidiano, procurando comover o público através de uma estética moralizante que corresponde a códigos preestabelecidos. Sua trama também é de certa forma imutável; o vilão acaba sempre desmascarado pelo herói, o bem sempre vence o mal, e assim a virtude é sempre premiada e o crime sempre punido. (Thomasseau, 2005, p. 6)

De fato, em $J F K$, o herói é personificado na figura do promotor Jim Garison e o desejo de punir o vilão, ou os vilões, surge da necessidade da população norte-americana de fazer justiça com um dos crimes mais intrigantes da história dos Estados Unidos: afinal, quem matou o presidente Kennedy? Em A Lista de Schindler, Oskar Schindler faz as vezes do herói enquanto o holocausto e toda a barbárie daí decorrente representam o mal que deve ser punido. E Em Nome do Pai, cria-se toda uma expectativa em corrigir um erro judicial que colocou atrás das grades pai e filho inocentes.

As docudramas, Schindler's List, In the name of the father, and JFK argue melodramatically for the worth of thought about their subjects. The films offer altenatives to the kind os sober discourse about history that would be the province os documentary. All operate as artistic perceptions of history, offering vieers the opportunity to share the film artistis reflections upon the historical material the works represent. On these terms, the films allow a sense of closeness to that history, an acces made possible by rendering chaotic, destructive horrors inderstandable essentially domestic conflitcts 
escalated to vastly larger social scales. The films suggest worlds from whitch morality has been lost then restored. Proximity to the factual in the films attempts to root artistic vision within the sober ground of historical actuality, suggesting at the same time that good has come out of suffering, that justice has prevailed, that - as it must in melodrama - some order has been restored to a chaotic universe. (Lipkin, 1999, p. 380)

Conforme já apontamos anteriormente, o programa Linha Direta da TV Globo pode ser considerado um dos exemplos mais representativos do gênero na televisão brasileira. A investigação de Linha Direta, enquanto docudrama, já está contemplada em outros estudos como o de Cannito (2003):

Linha Direta agrada ao público ao colocar "ordem nas coisas". No mundo ficcional do programa não há espaço para balas perdidas ${ }^{59}$. Seguindo um modelo de narrativa causal, Linha Direta abole o acaso e só mostra crimes com uma motivação clara e com uma lógica interna muito bem construída. $\mathrm{O}$ programa tem também um recorte ideológico explícito: prioriza os crimes passionais, a lógica da paixão e do melodrama. (Cannito, 2003 p. 173)

E Temer \& Tondato (2009, p. 145):

(...) boa parte do Linha Direta é ocupada com entrevistas ou depoimentos de pessoas que participam das histórias ou conheciam a vítima,um recurso do documentário que reforça a realidade da dramatização. De fato, parentes e vizinhos dão depoimentos, uma vez que é um recurso eficiente para a participação efetiva do público de baixo nível sociocultural.

Podemos afirmar que o docudrama tem encontrado cada vez mais espaço nas emissões televisuais e, em especial, no Brasil com significativo interesse do público. Além dos já comentados Linha Direta e Por Toda Minha Vida, outros programas, com apelos mais populares, produzem quadros de programa ligados ao gênero. O SBT, através do programa Domingo Legal, produziu durante o ano de 2008 o quadro Aconteceu Comigo, reconstituindo tragédias, catástrofes e acidentes relatados pelos espectadores. Na Rede Bandeirantes, a apresentadora Marcia Goldsmith também faz uso do gênero ao recriar histórias fantasmagóricas e assustadoras relatadas por pessoas que assistem ao seu programa. Vale

59. Notamos que no capítulo da novela Duas Caras no ar em 15/10/2007, Aguinaldo Silva retrata a questão das balas perdidas matando o personagem vivido por Herson Capri, que é atingido enquanto assistia a uma apresentação num circo. Em Linha Direta, no ar em 11/10/2007, o tema das balas perdidas foi abordado em programa especial que abordou exclusivamente este assunto. 
ressaltar que a televisão a cabo é responsável por boa parte da produção de docudramas. A Discovery Channel recorre ao gênero quando tem que reconstituir histórias de crimes e investigações forenses ou quando produz programas baseados em acidentes aéreos.

Em janeiro de 2009, a TV Globo, através do programa Fantástico, estreou o quadro Anjo da Guarda, no qual algumas personalidades brasileiras tiveram seu cotidiano reconstituído na forma de ficção, apresentando as pessoas que são verdadeiros anjos da guarda dessas celebridades, pois funcionam como o "braço direito" delas, controlando toda a sua agenda de compromissos. Desse modo, o quadro retratou os "Anjos da Guarda" de Ivete Sangalo, Gisele Bundchen e Graziela Massafera. A TV Record, através do programa do Gugu, apresenta aos domingos o quadro Nasci de Novo, um docudrama baseado em relatos de vítimas de acidentes de trânsito nas grandes cidades brasileiras. Numa mistura de encenação (simulação), depoimentos, fotografias e imagens de arquivo, um das produções deste docudrama reconstituiu o acidente com as vigas do Rodoanel Mario Covas na rodovia Régis Bittencourt, ocorrido em 13/11/2009. Ainda na TV Record, encontra-se em fase de préprodução um docudrama sobre a vida do escritor Machado de Assis. Com previsão para ir ao ar a partir de junho de 2010, o docudrama é uma co-produção entre a Record e a produtora independente Contém Conteúdo.

Tanto Linha Direta quanto Por Toda Minha Vida são programas que merecem uma análise um pouco mais elaborada no sentido de compreender em que medida essas produções podem ser lidas como docudramas. Nessa perspectiva, separamos um episódio de cada um desses programas: A maldição do Edíficio Joelma e o especial Mamonas Assassinas. Mas antes, focaremos no termo docudrama a fim de compreender melhor as convenções do gênero. O que propomos, em última análise, é reconhecer nessas obras características comuns ou marcas textuais que nos permitam pensar numa proposta de leitura de docudramas. Afinal,o que é docudrama? É oportuno ponderar que o docudrama é um gênero que se resolve em um único episódio ou, dito de outra maneira, não prevê uma serialização cujos fatos se desenvolvem em mais de um episódio ou capítulo. Nas produções contemporâneas de minisséries, por exemplo, são proeminentes as sinopses e os roteiros que tratam de biografias de pessoas públicas como JK (Globo, 2006), Maysa - quando fala o coração (Globo, 2008) e Dalva e Herivelto - Uma canção de amor (Globo, 2009). Trata-se de obras que manifestam personalidades ou pessoas famosas como enunciadores reais e que, portanto, se propõem a dramatizar biografias. Como vimos, esta é uma das características fundamentais do 
docudrama. Entretanto, defendemos que essas obras não são docudramas, pois são divididas em diversas partes. Talvez o termo mais adequado para pensar estas produções seja o de docu-soap ${ }^{60}$, que é um "tipo de documental serializado, realizado para televisión, que toma como protagonistas personajes reales y explora su trayectoria em diversos episodios para explicar sus vidas como si fuesen historias de ficción”. (Ramos \& Marimóm, 2002, p. 196).

\subsection{Fait divers como matriz temática e estrutural do docudrama}

Tal qual o fait divers, num docudrama, o que se coloca em destaque são histórias extraordinárias que, de um certo modo, tiveram repercussão social, seja porque as pessoas envolvidas são famosas ou porque os assuntos retratados chocaram a opinião pública dado o caráter de crime hediondo, tragédias e histórias sobrenaturais.

Uma outra característica do fait divers é de se passar por uma história verídica, atual e próxima do leitor. De fato, o fait divers fascina pela ilusão da sua proximidade. A acumulação dos detalhes que dão credibilidade, os assuntos e as confidências, tanto dos autores dos crimes quanto das vítimas, as entrevistas e as fotografias, são muitos dos procedimentos que contribuem para a autenticidade da narrativa e a ilusão da proximidade. (Dion, 2007, p. 126)

Em certa medida, o docudrama é uma versão atualizada e em forma de audiovisual dos fait divers, uma espécie de crônica adaptada ao romance-folhetim e que fez grande sucesso entre os leitores no século XIX. Os temas tratados eram os mais diversos; iam desde casos reais de pessoas condenadas à guilhotina até escândalos religiosos e conjugais. O fait divers consiste numa "notícia extraordinária, transmitida em forma romanceada, num registro melodramático, que vai fazer concorrência ao folhetim e muitas vezes suplantá-lo nas tiragens", pontua Meyer (1996, p. 98). Como veremos adiante, o docudrama, como os fait divers, elege as histórias extraordinárias que mexeram com a opinião pública, como catástrofes, acidentes, assassinatos, mistérios, entre outros.

De certo modo, o folhetim está para a telenovela assim como os fait divers para o

60. Lançamos, aqui, a hipótese de que o docu-soap é uma forma de docudrama seriado. A verificação desta hipótese não faz parte dos objetivos da presente investigação. Todavia, registramos a importância desse assunto e a necessidade de seu estudo em investigações futuras como forma de contribuição ao campo científico da ficção seriada. 
docudrama. Como é sabido, o folhetim após ser lançado em tiras de jornais, fez grande sucesso nas ondas do rádio, com as radionovelas, e chegou à televisão transformando-se numa das produções mais populares e de maior audiência: a telenovela. Seguindo essa mesma linha de raciocínio, o fait divers também fez carreira no rádio através de programas populares apresentados por radialistas como Gil Gomes, que apresentou por vários anos um programa radiofônico que dramatizava crimes hediondos em sua maioria cometidos na sociedade paulista. O mesmo locutor transforma-se em repórter policial do clássico programa Aqui Agora do SBT, durante a década de 1990. No estilo desgraça pouca é bobagem, o programa fez escola estimulando a criação de programas similares como o 190 Urgente (CNT) e Cidade Alerta (Record). Esses programas obtiveram grande popularidade entre os espectadores da época.

Dejavite (2001) afirma que diversos programas de televisão exploram o fait divers como forma de aumentar o interesse pela audiência e que, nessa perspectiva, o telejornal se mostra como o formato que cada vez mais aborda em suas produções assuntos de comoção nacional, violência e tragédias. E complementa:

Fait divers, etimologicamente, remete à notícia do dia ou ao fato do dia. $\mathrm{Ou}$ seja, este termo francês relaciona-se às notícias variadas, que têm importância circunstancial, constituindo-se em um elemento relevante para a promoção e "alimentação" do entretenimento no noticiário. Um exemplo clássico de fait divers, que também serve para definir o que é notícia, é a velha história, atribuída a Amus Cummings, editor do New York Sun, que propõe a seguinte taxinomia: se um cachorro morder a perna de um homem, não é notícia; mas se um homem morder a perna de um cachorro, é notícia. É claro que faz parte das atividades normais de um cachorro sair por aí mordendo as pernas daquelas pessoas com as quais ele não simpatiza, mas um homem morder as pernas dos cachorros de que ele não gosta, podendo usar o pé para enxotá-los, é absurdo. Daí o interesse de todo mundo em querer saber por que um cidadão adotou atitude tão esdrúxula. Esse fato narra o inusitado ou o sensacional, no sentido do que causa sensação ou emociona. (Dejavite, 2001, p. 6)

Roland Barthes (2009) introduz a discussão acerca dos fait divers no livro Essais Critiques, em 1964. Para Barhes (2009, p. 215) o fait divers "seria uma informação monstruosa análoga a todos os fatos excepcionais ou insignificantes(...)” e também observa que:

Não há necessidade de conhecer nada do mundo para consumir um caso do 
dia $^{61}$; ele não remete formalmente para outra coisa que não seja ele próprio; evidentemente, o seu conteúdo não é estranho ao mundo: desastres, homicídios, raptos, agressões, acidentes, roubos, extravagâncias, tudo isso remete para o homem, para a sua história, para sua alienação, para os seus fantasmas, para os seus sonhos, para os seus medos; são possíveis uma ideologia e uma psicanálise do caso do dia; mas trata-se aí de um mundo cujo conhecimento nunca é senão intelectual, analítico, elaborado em segundo grau por aquele que fala do caso do dia, não por aquele que o consome; ao nível da leitura, tudo é dado num caso do dia; as suas circunstâncias, as suas causas, o seu passado, o seu resultado; sem duração e em contexto, constitui um ser imediato, total, que não remete, pelo menos formalmente, para nada de implícito; é nisso que se parece com a novela e com o conto, e não mais com o romance. É a sua imanência que define o caso do dia. (Barthes, 2009, p. 216)

Evidentemente, quando Barthes coloca que o fait divers não é elaborado por aqueles que o consomem está implícita aí a ideia de que esse gênero é um produto típico da cultura de massa e da indústria da cultura, e que seu objetivo, em última análise, é vender ou assegurar a audiência. Dito de outra maneira, são construções narrativas simples, facilmente compreensíveis e que contemplam valores e sentimentos universais, dispensando leituras mais elaboradas que requeiram repertórios ou conhecimentos técnico-científicos prévios. Basta o conhecimento do senso comum. Talvez resida aí o caráter pejorativo que frequentemente se atribui ao gênero:

A expressão fait divers não designa, portanto, somente uma atividade de distribuição das notícias entre as rubricas de um jornal, ou um tipo de informação, mas também, com uma conotação explicitamente pejorativa, uma categoria particular de acontecimentos. (Meyer, 1996, p. 98).

Tal qual o fait divers, conforme apontado por Barthes, o docudrama é imanente, efêmero, espantoso e sensacionalista. Sem almejar as discussões filosóficas que a noção de imanência possa vir a provocar, ela sinaliza algo que contém em si todo o seu saber e sugere uma informação total. Dito de outra forma, o leitor/espectador se contentará apenas com a história abordada dentro do docudrama. É como se ele emitisse todas as informações necessárias a sua compreensão sem recorrer a discussões que, eventualmente, estejam fora da narrativa. Em outras palavras, importa menos a informação e mais a representação dramatizada do fato:

61. Curiosamente, a versão do livro essais critiques em língua portuguesa traduziu a noção de fait divers como "casos do dia". 
Os problemas apresentados pelo Linha Direta são pontuais, não há espaço para análises mais aprofundadas ou para explorar temas mais complexos. As soluções citadas e as sugestões feitas não vão além do senso comum e dos palpites vazios. Dessa forma, o programa não retrata a realidade, mas, antes, representa um exercício sutil de construção de pretensas realidades, gerando a sensação de que tudo é permanentemente desorganizado. A audiência do programa é segurada pela promessa de uma possibilidade de justiça. (Temer \& Tondato, 2009, p. 146,).

O caráter de imanência do docudrama indica que:

(...) o espectador não deve trabalhar por conta própria: o produto prescreve toda reação: não pelo seu contexto objetivo - que se desfaz tão logo se dirige à capacidade de pensar -, mas mediante sinais. Toda conexão lógica, que requeria intuição intelectual, é escrupulosamente evitada. (HorkheimerAdorno apud Wolf, 2003, p. 79).

Por outro lado, algumas produções textuais, que exigem conhecimentos externos à narrativa, manifestam um caráter exógeno (Barthes) e não se pode compreender a informação de imediato. Por exemplo, algumas obras audiovisuais, pelo seu caráter informativo (Reportagens especiais, documentários, entre outros), necessitam que o leitor/espectador recorra a discussões que vão além da narrativa, estabelecendo conexões com outras áreas do conhecimento, como a sociologia, psicologia, antropologia, etc.

Os assuntos que alimentam o docudrama são efêmeros. Essa efemeridade repousa nas temáticas e nos fatos preferidos do gênero: crimes passionais, incêndios, desastres que chocam pelo inesperado e pelas proporções, e são demasiadamente explorados pela imprensa mas que, passado um determinado tempo, tendem a ser esquecidos. Contraditoriamente, apesar de seu caráter efêmero, o assunto ou fato retratado é, vez por outra, relembrado, resiste ao tempo e permanece numa espécie de "arquivo", pronto para realimentar e repetir os dados em outras representações. Por exemplo, o clássico incêndio do edifício Joelma, ocorrido no centro de São Paulo na década de 1970, transformou-se em filme na década de 1980, e o programa Linha Direta resgatou esse mesmo assunto e o transformou em docudrama no final da primeira década dos anos 2000. Em certas feitas, os telejornais recorrem a esses "arquivos" para ilustrar suas matérias que cobrem, por exemplo, incêndios que acontecem na atualidade.

Barthes (2009) afirma que a estrutura de funcionamento imanentes ao fait divers enquadra-se em dois momentos: um na relação de causalidade e outro na relação de 
coincidência. Na relação de causalidade os fait divers, apoiam-se numa estrutura que prevê a elação entre dois termos ou anotações, diz Barthes. Por outras palavras, por trás de um crime sempre há uma explicação, por mais extravagante que seja, que tenta descrever os motivos do acontecimento, quais sejam razão passional, por roubo, por dinheiro, por ódio, etc.

Mas em todos os casos onde a causalidade é de certo modo normal, esperada, a ênfase não é posta na própria relação, embora ela continue a formar a estrutura da narrativa; ela desloca-se para aquilo que se poderia chamar as dramatis personae (criança, velho, mãe, etc), espécies de essências emocionais, encarregadas de vivificar o estereótipo. (Barthes, 2009, p. 218)

A respeito disso, as manchetes de jornais populares como Agora (2010), de São Paulo, são sintomáticas: Irmão morre baleado ao tentar salvar irmã que estava sendo roubada ou Preso estupra jovem durante saída temporária do $\mathrm{Natal}^{62}$. Com efeito, é na relação entre dois termos ou duas ideias que os fait divers se configuram. Nos exemplos anteriores, o que choca não é tanto o crime em si, mas na relação com um termo inesperado como aponta Barthes. $\mathrm{O}$ irmão morre baleado. Foi assaltado? Não. Morreu porque tentou salvar a irmã. Preso estupra jovem. É sua ex-namorada? Não. Ele comete o delito numa época sagrada que é o natal. Como é notável, "não há caso do dia (fait divers) sem espanto”. (Barthes, 2009, p. 218, grifo nosso). Outros exemplos sintomáticos dessa estrutura podem ser apontados também nas telenovelas. Na novela Páginas da Vida (Globo, 2006), alguns dos depoimentos de pessoas "reais" espantaram pelo conteúdo polêmico, como o caso de uma senhora de 68 anos relatando seu primeiro orgasmo aos 45 anos. Segundo artigo do jornal Folha de São Paulo, publicado em 17/07/2006, a própria TV Globo admitiu que houve excesso e prometeu controlar o conteúdo dos depoimentos. O referido depoimento entrou na sequência de uma cena onde a atriz Ana Paula Arósio fazia striptease. Botei a vitrola a música Côncavo e Convexo e fui dormir. E simplesmente, gente, quando eu acordei, eu estava com a perna suspensa, a calcinha na mão, e toda babada. O esperado nesse depoimento era o relato de uma pessoa jovem, mas nunca uma senhora. Nesse mesmo artigo, o autor de Páginas da Vida, Manoel Carlos, defende-se: "Lamento e peço desculpas se ofendi e choquei algumas pessoas. Não era minha intenção. Todo o valor dos depoimentos está exatamente no espontâneo. Na sinceridade".

As relações de causalidade, afirma Barthes, são organizadas pelo inexplicável e pela 
surpresa dos números. O inexplicável, por sua vez, pode ser compreendido em duas categorias de fatos: os prodígios - ou "fenômenos do céu", óvnis, discos voadores, objetos não identificados - e os crimes. Em razão dos estereótipos, os fait divers são ricos em desvios de causalidade. Ao contrário de uma causa esperada, aparece outra, geralmente mais banal. É interessante notar as manchetes dos casos reconstituídos do programa Linha Direta: "Matou a namorada e foi ao barbeiro", metáfora explícita do filme "Matou a Família e Foi ao Cinema"63; "Bodas de Sangue" e "Traição cega", dignas dos programas policiais e sensacionalistas como o extinto Aqui Agora do SBT e da imprensa sensacionalista, como o jornal Notícias Populares. Outra forma de causalidade reside na "surpresa dos números (ou mais latamente, da quantidade)". (Barthes, 2009, p. 220). Não raro, os fait divers espantam pela relação causal estabelecida por um número exorbitante ou por uma pequena quantidade que é capaz de provocar estragos de grandes proporções, como no exemplo dado pelo autor: um comboio descarrila no Alaska: um veado tinha bloqueado a agulhagem. Por outro lado, a causalidade irrompe em um número grande de mortos em um único acidente, como comumente acontece em desastres aéreos cujos números são estampados na capa de um jornal de grande circulação.

A segunda relação da estrutura da narrativa do fait divers é representada pela coincidência: é, “em primeiro lugar, a repetição de um acontecimento, por insignificante que ele seja, que o aponta à notação de coincidência: uma mesma joalheria foi assaltada três vezes ; uma dona de pensão ganha em cada lance na loteria,etc", complementa Barthes (2009, p. 222). Reconhece-se aí a noção de repetição como algo inerente ao mecanismo de funcionamento do fait divers e, consequentemente, no docudrama.

As telenovelas precisam das repetições, e pode-se dizer que estas fazem parte de sua estratégia narrativa. Segundo Aristóteles, é necessário que uma trama tenha a extensão que a memória possa abranger. É possível nas tramas para o cinema e teatro, mas na telenovela a situação é oposta. Ela não tem um tamanho que possa ser contido pela memória comum. Para complicar, as histórias continuam no dia seguinte, e a vida do espectador interpõe inúmeras informações e assuntos entre um capítulo e outro. Até mesmo em um único capítulo, há interrupções em que se podem ver propagandas de outros programas, anúncios de produtos que remetem à realidade extradiegética, assim como a divulgação de modos de vida supostamente ambicionados pelo espectador. Portanto, é razoável que se repitam assuntos, problemas e características dos personagens para ajudar na memorização e compreensão do público. (Sadek, 2008, p. 76)

63. Disponível no site www.globo.com/linhadireta acessado em 15/11/2006 
O grande desafio das telenovelas, dos docudramas e de outros produtos audiovisuais é o de tentar inovar dentro de um mesmo esquema narrativo.

É o caso nos meios de comunicação de massa, do filme comercial, dos quadrinhos cômicos, da música e dança e - sem dúvida - do assim chamado seriado de televisão, onde se tem a impressão de ler, ver, escutar sempre alguma coisa nova enquanto, com palavras inócuas, nos contam sempre a mesma história (Eco, 1989, p. 121,).

Desse modo, em um docudrama, o espectador de antemão já sabe que se trata de uma história real dramatizada inspirada em fatos extraordinários, e em uma telenovela, um par romântico que vence obstáculos de toda ordem para ficar junto no final da trama. Tal reflexão se sustenta em parte. Aceitá-la como verdade seria por demais simplificador. Essa visão negativa, ou apocalíptica nos dizeres de Umberto Eco, se deve,em parte, aos seguidores da teoria crítica:

Quando a estética moderna se viu diante de obras produzidas pelos meios de comunicação de massa, negou-lhes qualquer valor artístico exatamente porque pareciam repetitivas, construídas de acordo com um modelo sempre igual, de modo a dar a seus destinatários o que eles queriam e esperavam, Definiu-as como objetos produzidos em série, assim como se produzem muitos automóveis do mesmo tipo, segundo um modelo constante. Aliás, a serialidade dos meios de comunicação de massa foi considerada mais negativa que a da indústria. (Eco, 1989, p. 120)

\subsection{Docudrama no Discovery Channel}

Com o objetivo de ilustrar, empiricamente, as relações de causalidade e coincidência discutidas por Barthes (2009), tomaremos como exemplo um episódio de docudrama produzido pelo canal Discovery Channel exibido em 10/06/2007 $7^{64}$. O título da produção já sugere a enunciação real: A tragédia do voo 1907. Como é sabido, trata-se da história real do avião da Gol que colidiu com outro avião de pequeno porte, em 29/09/2006, acabando por desintegrar-se no ar em plena floresta amazônica deixando um saldo de 154 mortos

64.Frequentemente, jornalistas de veículos impressos e de grande circulação denominam produções audiovisuais de "documentários" quando, na verdade, tratam-se de "docudramas". A exemplo da matéria intitulada Sem novidades, o documentário sobre voo 1907 opta pelo didatismo, publicada no jornal Folha de São Paulo em 30/05/2007; disponível em: http://www1.folha.uol.com.br/folha/ilustrada/ult90u300784.shtml, acessado em $11 / 01 / 2010$. 
representando, até a ocasião, o pior acidente aéreo do Brasil. Como é óbvio, interessa, e muito, à imprensa explorar uma tragédia dessas proporções , tanto local, quanto internacional. Há uma curiosidade imediata que tende a ser tratada nos mesmos moldes do faits divers: em primeiro lugar, o assunto em si já apresenta uma temática-chave: a tragédia. Em segundo, trata-se de algo raro e com grande potencial de interesse e comoção populacional. É efêmero na medida que é intensamente explorado, mas logo é esquecido, afinal, quais foram as verdadeiras causas do acidente? Os parentes das vítimas foram indenizados? Os culpados foram punidos? As respostas para esses questionamentos não são divulgadas com a mesma intensidade e interesse dispensado na ocasião em que o fato ocorre. É espantoso em razão de sua raridade, é um fato completamente inesperado. A cobertura é sensacionalista, na medida em que:

\begin{abstract}
No sensacionalismo, as balaustradas da vida normal são rompidas pelo acidente, a catástrofe, o crime, a paixão, o ciúme, o sadismo. O universo do sensacionalismo tem isso em comum com o imaginário (o sonho, o romance, o filme): infringe a ordem das coisas, viola os tabus, compele ao extremo a lógica das paixões. Tem em comum com a tragédia o fato de se sujeitar à implacável fatalidade. É esse universo de sonho vivido, de tragédia vivida e de fatalidade que valorizam os jornais modernos do mundo ocidental. (Morin, 2009, p. 100)
\end{abstract}

Nos moldes de um típico docudrama, o episódio inicia-se com uma locução:

Locutor: Dois aviões rumo a um desastre impensável. O pior acidente aéreo da história do Brasil ..

Em duas frases já se manifesta o caráter espantoso - “desastre impensável” - e sensacionalista - "o pior acidente".

Sonora: Como duas aeronaves conseguem colidir no ar num espaço tão grande desse?

Locutor: $O$ que poderia ter causado esta colisão?

Sonora: Foi uma sucessão de erros... coincidências inacreditáveis.

Locutor: O Discovery Channel reúne todas as peças deste quebra cabeça assustador. Na cabine, junto aos investigadores, e dentro do mundo secreto do controle de tráfego aéreo. 
Descubra a história real por trás da tragédia do voo 1907.

É interessante notar que, em menos de um minuto, essa produção já reúne as principais características do fait divers e do docudrama. Além do espantoso e do sensacionalista, já se manifestam as relações de causalidade - O que poderia ter causado esta colisão? - de coincidência - Foi uma sucessão de erros... coincidências inacreditáveis - e de imanência: "reúne todas as peças" ... "descubra a história real"... é como se o episódio do docudrama fosse um todo, contivesse todas as informações necessárias acerca do acidente e correspondesse à totalidade dos fatos: "descubra a história real".

Com uma edição que mistura imagens de arquivo e dramatizações, os relatos são uma constante e reforçam as relações de causalidade e coincidência:

Sonora: - A aeronáutica é tão sofisticada, tem tantos mecanismos pra você ir corrigindo erros e vão falhando todas as instâncias pra evitar aquele erro...

Sonora: - Houve uma conjunção mesmo de erros, de falhas, erros de procedimentos que vieram a causar o acidente, então realmente foi uma cadeia. (Wellington Rodrigues controlador de tráfego aéreo,).

Sonora: - A batida foi exatamente no momento que o boeing estava saindo do controle de Manaus para entrar no espaço aéreo controlado pelo Cindacta I em Brasília, e o Legacy estava saindo do espaço de Brasília pra encontrar o de Manaus naquele momento. (Eliane Cantanhêde - Folha de São Paulo,)

Sonora: - Coincidências acontecem sim, mas esse acidente poderia ter sido evitado sim... (Neuza Machado - parente de vítima,)

Sonora: -Existem várias falhas, vários erros cometidos por várias pessoas... foi uma sucessão de erros (Jorge Cavalcante - Associação de Familiares de Vítimas,) .

Sonora: - Na teoria do dominó, mas infelizmente nesse acidente todos os dominós que poderiam ter sido retirados, eles não foram retirados. Como todo cenário de acidente, ele é realmente o resultado de vários fatores, nunca de um fator isolado (Coronel Rufino Ferreira 
- Presidente, comissão investigadora,).

Sonora: - Eu não tenho religião, eu não sou mística, mas a história desse acidente, ela é cheia de coincidências inacreditáveis. (Eliane Castanhêde - Folha de São Paulo,)

Somam-se, ainda, a essa produção, na relação de causalidade, a surpresa dos números: em um acidente morreram $\underline{154}$ pessoas; e os fatos inexplicáveis: o milagre da sobrevivência dos pilotos John Lepore e Jean Paul Paladino e dos demais passageiros do avião Legacy que consegue, mesmo danificado, fazer um pouso de emergência.

Nas telenovelas, as coincidências constituem um recurso básico de narrativa à disposição de seus autores. "Em dramas que valorizam a causalidade, acidentes e coincidências são aceitos com reservas. O cinema usa esses elementos com muita parcimônia", sustenta Sadek (2008, p. 73). Ele acrescenta:

A coincidência merece um breve comentário. Para uma narrativa preocupada
com causas e efeitos como a do cinema clássico, as coincidências são pouco
admiradas. Os manuais de filmografia explicitam que as coincidências não
são bem-vindas por serem sintomas de situações pouco elaboradas. Os
dramaturgos, antigos ou modernos, evitam esse recurso. (Sadek, 2008, p.
73).

De outra parte, Sílvio de Abreu, tradicional e renomado autor de novelas da TV Globo, em depoimento ao programa Cena Aberta (Globo, 2003), dirigido por Guel Arraes, Jorge Furtado e Regina Casé diz: “Às vezes a gente precisa recorrer às coincidências. Quando essa coincidência é bem bolada, é bem crível, a história desenrola muito melhor. Coincidência existe em tudo o que é novela".

\subsection{Proposta de leitura docudramentarizante}

Propomos o neologismo docudramentarizante para pensar na estrutura do docudrama e organizar uma forma de leitura que seja capaz de compreender características formais e estéticas do gênero. Evidentemente, esse neologismo é diretamente baseado na proposta de leitura de documentários, publicada na revista Cinemas et realités65, a qual Roger Odin (1984) chamou de leitura documentarizante. Nessa leitura, Odin propõe figuras estilísticas

65.Ver ODIN Roger. Film documentaire, lecture documentarizante, in: ODIN, R e LYANT, J.C. (ed): Cinemas et réalites. Saint-Etienne: Universidade de Saint-Etienne, 1984, traduzido por Samuel Paiva. 
que estimulam o leitor a construir e perceber a presença real de um enunciador como foco embaçado, imagens trêmulas, golpes de zoom, longos planos-sequência e iluminação deficiente, entre outros. Em outras palavras, o que Odin buscou compreender é como analisar um material audiovisual como sendo documentário. Em relação ao docudrama? É possível identificar e propor mecanismos de análise que possam servir como roteiro de proposta de uma leitura docudramentarizante? Tal proposta de Roger Odin manifesta-se particularmente importante para os caminhos que a presente investigação busca trilhar, já que o documentário representa um dos importantes pilares que estruturam o docudrama. Além disso, a forma como a leitura documentarizante se constrói nos permite pensar, reconhecer, desmontar e organizar os elementos constitutivos de um docudrama para finalmente propor uma forma e, por que não dizer, um método de leitura deste gênero?

Quando Odin propõe mecanismos da leitura documentarizante, ele a operacionaliza em oposição a uma leitura fictivizante, ou seja, que todo filme pode ser submetido a um "leitor" que fará uma dessas leituras. Desse modo, a leitura documentarizante recai "não sobre a realidade ou não realidade do representado, mas sobre a imagem que o leitor faz do Enunciador". (Odin, 1984, p. 1, grifo nosso). E esse "leitor" ou espectador deverá construir um enunciador pressuposto real no caso dos documentários e se recusar a construir um enunciador para a história contada no caso da ficção. "O enunciador e o enunciatário são o autor e o leitor. Não são o autor e o leitor reais, de carne e osso, mas o autor e leitor implícitos, ou seja uma imagem do autor e do leitor construída pelo texto", pontua Fiorin (2009, p. 56). Equivocadamente, o enunciador tende a ser lido meramente como o autor de uma obra e o enunciatário como o leitor. Essa compreensão mais ampla das figuras dos enunciadores e enunciatários ainda fica mais evidente quando se trata de uma produção audiovisual, na qual há uma equipe composta por diversas pessoas que executam variadas funções e que, portanto, constituem-se nas várias vozes que compõem o enunciado.

O enunciado é a manifestação textual, é a narrativa em si:

O texto narrativo que se encarrega da história a ser contada. Porém, esse enunciado que, no romance, é formado apenas de língua, no cinema, compreende imagens, palavras, menções escritas, ruídos e música, o que já torna a organização da narrativa fílmica ainda mais complexa. (Aumont, 1995, p. 106).

Como veremos adiante, os enunciadores reais não são, de fato, as pessoas, mas os papéis que elas desempenham num set de gravação: é o cameraman, o realizador, o 
responsável pelo discurso, assim por diante.

Odin nos ensina que há diversas maneiras de se pôr em ação a leitura documentarizante, entre elas:

1. O leitor pode tomar a câmera como enunciador real. Nessa perspectiva, tudo que se encontra diante da câmera (cenário, figurino, personagem, etc), torna-se objeto da leitura documentarizante.

2. O leitor pode tomar o cinema como Enunciador real. É bem evidente que é esse tipo de leitura que interessa aos teóricos (historiadores, semiólogos) do cinema.

3. O leitor pode tomar a sociedade na qual o filme é produzido como Enunciador real. Aqui se reconhecem a leitura histórica e a leitura sociológica.

4. O leitor pode tomar o cameraman (o fotógrafo) como enunciador real. É o caso típico de filme de reportagem. O pressuposto do leitor, nesse caso, é de que o câmera se encontra no local onde os fatos acontecem.

5. O leitor pode tomar o realizador do filme como enunciador real. Tratase da leitura cinéfila, que faz de todo filme um documento sobre seu "autor" ou ainda da leitura psicanalítica, a que já se fez alusão.

6. O leitor pode tomar o responsável pelo discurso do filme como Enunciador real. Esse responsável não se confunde com o realizador. Em um filme pedagógico, por exemplo, a realização é assegurada por um profissional de cinema, mas a responsabilidade do discurso é do professor, do pesquisador ou do especialista que se exprime o filme. (Odin, 1984, p. 4 )

O docudrama é necessariamente uma composição híbrida entre convenções formais dos documentários com as marcas textuais tradicionais do melodrama ou, em outros termos, o docudrama, assim como os documentários, deverá pressupor a existência de um Enunciador real combinado com elementos próprios da ficção (encenação, dramatização) e com um forte apelo melodramático. Para realizar uma leitura de docudramas (leitura docudramentarizante), o leitor/espectador deverá reconhecer ou operacionalizar enunciadores reais. Dentre as diversas vozes que se manifestam como enunciadores, como é evidente, o reconhecimento de um fato histórico ou social real no enunciado é condição sine qua non para tratar um material audiovisual - quer seja ele cinematográfico ou televisual - como docudrama. É capital que o filme ou programa de televisão se enuncie como baseado em fatos reais de forma explícita ou implícita. Geralmente o que ajuda o leitor/espectador a construir o fato social ou histórico como enunciador real é que o fato em si já fora publicado em outros canais de informação em um jornal ou reportagem de televisão - tomando grandes repercussões sociais e que, muitas vezes, estimula debates entre a opinião pública. 
Para efetuar uma leitura docudramentarizante, o leitor/espectador, além de reconhecer os fatos históricos ou sociais como enunciadores reais, poderá, também, tomar o personagem como enunciador real. Nessa perspectiva, o leitor reconhece nos docudramas pessoas famosas ou não que têm seus históricos de vidas reconstituídos em caráter biográfico. É o caso do já comentado programa de televisão Por Toda Minha Vida, que homenageou, de forma póstuma, personalidades conhecidas por seus grandes feitos musicais. O leitor/espectador poderá tomar como enunciador real o cameraman nas situações em que relatos e depoimentos são filmados com pessoas olhando diretamente para a câmera em uma estrutura de edição semelhante à de um noticiário. $\mathrm{O}$ aparato tecnológico está ali no local onde os fatos efetivamente acontecem. O leitor/espectador poderá tomar como enunciador real o âncora/apresentador que, semelhante a um programa de noticiários, buscará dar mais credibilidade aos assuntos tratados, promovendo um encadeamento lógico na narrativa, funcionando quase como um testemunho de que aqueles assuntos tratados são reais. $\mathrm{O}$ leitor/espectador poderá tomar como enunciador real a ancoragem do tempo e do espaço da narrativa, reconhecendo o local e as datas como verdadeiras. O leitor/espectador poderá tomar como enunciador real as imagens de arquivo - na forma de fotografia ou de vídeo - como documentos que comprovam que as pessoas envolvidas estiveram naquele tempo e espaço dos fatos.

Notamos que contar a vida de alguém é uma temática comum nos docudramas. Com efeito, a biografia é tomada como enunciador real. Nesse sentido, Philippe Lejeune, em Pacto autobiográfico ${ }^{66}$, nos ensina que:

Muitos filmes projetados em encontros do tipo "cinema e autobiografia" são ficções. O cinema-verdade é mais fácil de ser concebido no campo da reportagem, do relato de viagem, do documentário etnológico, quando a câmera focaliza o outro e o presente, do que no campo da autobiografia, quando ela deveria se voltar para si e para o passado. Quanto mais o cineasta tende a se aproximar da realidade, mais sensível fica, por vezes, o aspecto ficcional. (Lejeune, 2008, p. 228).

Enquanto uma reportagem de televisão se volta para o outro e o presente, a biografia tem como foco o outro e o passado. Há mecanismos de produção audiovisual que envolvem

66. Lejeune define Pacto autobiográfico como "narrativa retrospectiva em prosa que uma pessoa real faz de sua própria existência, quando focaliza especialmente sua história individual, em particular a história de sua personalidade" (2008, p. 49). 
pesquisa histórica e análise documental que buscam reconstruir, no presente, fatos do passado, da vida de um "outro".

Através do cinema, é possível identificar diversas obras autobiográficas ${ }^{67}$. Já a autobiografia no docudrama parece ser algo raro. Nesta investigação encontramos um único exemplo de docudrama autobiográfico, exibido pela rede norte-americana CBS em 1974: Autobiography of miss Jane Pittman, segundo Hoffer e Nelson (1999). A produção conta a história de Jane Pitmtman, uma menina escrava, que luta pelos direitos civis dos negros americanos.

Lejeune (2008, p. 227) afirma que "o cinema autobiográfico parece estar condenado à ficção". E complementa:

\begin{abstract}
Não posso pedir ao cinema para mostrar o que foi meu passado - minha infância, minha juventude -, posso apenas evocá-lo ou reconstituí-lo. A escrita não tem esse problema, pois o significante (a linguagem) não tem nenhuma relação com o referente. A lembrança de infância escrita é tão ficcional quanto a lembrança de infância reconstituída no cinema: mas a diferença é que posso acreditar e fazer acreditar que é verdadeira quando a escrevo, pois a linguagem não imita a realidade. No cinema, em contrapartida, a inautenticidade do artefato torna-se perceptível porque, a rigor, uma câmera teria podido registrar, outrora, a realidade do que, aqui, é representado por um simulacro. Assim, a "superioridade" da linguagem se deve antes a sua capacidade de fazer esquecer seu aspecto ficcional do que uma aptidão especial para dizer a verdade. $\mathrm{O}$ cinema tem a desvantagem de poder ser documental e a imagem, a desvantagem de estar sempre ligada a uma realidade. A criança que deve representar minha infância, o adulto a quem delego meu papel, as cenas que reconstituo não são de fato a realidade que querem ser. (Lejeune, 2008, p. 227-228)
\end{abstract}

Seja como for, o docudrama é necessariamente uma reconstrução de fatos e busca causar efeitos de realidade. Na maior parte das vezes, apresenta as seguintes características:

- Recriação baseada em fatos reais;

- Uso de atores não conhecidos do grande público, mas fisicamente semelhante às pessoas retratadas;

- Uso de materiais de arquivo: fotografias e filmagens domésticas antigas, reportagens, etc;

- Intercalação das tramas recriadas com entrevistas ou depoimentos com pessoas que presenciaram ou sofreram consequências dos fatos;

67. Ver 8 1⁄2 (1963) de Francisco Fellini, Sergei Eisenstein, uma autobiografia (1996) de Oleg Kovalov. 
- Forte apelo melodramático (retrato da família, forte apelo à emoção);

- Busca provocar efeitos ético-moralizantes;

- Geralmente trata de histórico de vidas ou biografias;

- Uso de voz over (locução), ancoragem mediada por um apresentador em texto em terceira pessoa;

- Montagem híbrida ${ }^{68}$.

Propomos que um docudrama seja toda obra audiovisual que preencha simultaneamente as condições sinalizadas em cada um dos três momentos (enunciador real ou referente, leitura fictivizante e melodrama) conforme exemplificamos no esquema a seguir:

68. Nesta investigação, chamamos de montagem híbrida um tipo de edição que busca criar efeito de realidade com a inserção de uma personagem da ficção "dentro" de uma imagem real (de arquivo). É como se o personagem estivesse no tempo e no espaço onde os fatos ocorreram. 


\begin{tabular}{|c|c|c|}
\hline $\begin{array}{l}\text { 1. Referente (construção de } \\
\text { enunciador real) }\end{array}$ & $\begin{array}{l}\text { 2. Leitura fictivizante ou } \\
\text { recusa de construção de um } \\
\text { enunciador real) }\end{array}$ & 3. Melodrama \\
\hline $\begin{array}{l}\text { Recriação baseada em fatos } \\
\text { reais; }\end{array}$ & $\begin{array}{l}\text { Preferência pelo uso de } \\
\text { atores não conhecidos do } \\
\text { grande público, mas } \\
\text { fisicamente semelhantes às } \\
\text { pessoas retratadas; }\end{array}$ & $\begin{array}{l}\text { Forte dramatização (retrato } \\
\text { da família, forte apelo à } \\
\text { emoção); }\end{array}$ \\
\hline $\begin{array}{l}\text { Uso de materiais de arquivo: } \\
\text { fotografias e filmagens } \\
\text { domésticas, reportagens, etc; }\end{array}$ & $\begin{array}{l}\text { Reconstrução dos fatos } \\
\text { através da encenação; }\end{array}$ & $\begin{array}{l}\text { Busca provocar efeitos ético- } \\
\text { moralizantes; }\end{array}$ \\
\hline $\begin{array}{l}\text { Intercalação das tramas } \\
\text { recriadas com entrevistas ou } \\
\text { depoimentos com pessoas } \\
\text { que presenciaram ou } \\
\text { sofreram consequências dos } \\
\text { fatos; }\end{array}$ & $\begin{array}{l}\text { Uso de créditos que } \\
\text { indiquem "simulação" ou } \\
\text { "dramatização". }\end{array}$ & $\begin{array}{l}\text { Sugere a punição de um } \\
\text { "vilão" ou a exaltação de um } \\
\text { herói. }\end{array}$ \\
\hline $\begin{array}{l}\text { Ancoragem de datas e locais } \\
\text { dos fatos reconhecíveis como } \\
\text { "verdadeiros" pelo leitor/ } \\
\text { Espectador. }\end{array}$ & & \\
\hline
\end{tabular}

Em relação ao documentário, Odin (1984) afirma:

Um filme pertence ao conjunto do documentário quando ele integra explicitamente em sua estrutura (de um modo ou de outro) a instrução (consigne) de pôr em ação (mettre em oeuvre) a leitura documentarizante: quando ele programa a leitura documentarizante (Odin, 1984, p.5).

Odin sugere que essa instrução pode se manifestar nos créditos ou no próprio texto de um filme e exemplifica:

- Presença de uma legenda (carton) indicando claramente que se trata de um documentário: "uma reportagem de...", "uma enquete filmada...";

- Presença de uma legenda (carton) designando uma estrutura de produção 
especializada em filme documentário: "L'OFRAMETE présent...”;

- Ausência de nomes de atores (nos créditos);

- Forma do título: títulos como Notre planète la terre (Painlevé), Le tonnelier, Le charron (Rouquier), Bucherons de la Manouane (Lamothe) anunciam sem ambiguidade um documentário;

- Ausência de crédito (essa marca por ausência evidencia um fraco nível de elaboração do texto fílmico proposto; $\underline{0}$ filme se mostra como não sendo nem uma obra e nem mesmo uma mensagem: é um simples documento; essa figura, presente nos filmes de família, encontra-se igualmente em certos filmes médicos, etnográficos, etc. (Odin, 1984, p. 5)

De outra parte, nos docudramas, há instruções para que o leitor/espectador programe a leitura de um texto audiovisual como docudrama, são eles:

- Inserção de legendas tais como: "este filme é baseado na história real de" ou simplesmente "baseado em fatos reais";

- Presença nos créditos finais com informações do tipo: "tal pessoa cumpriu doze anos de prisão e hoje vive na cidade de Nova York em condicional";

- Uso de palavras como "simulação" e "arquivo", a exemplo das edições de Linha Direta ou "dramatização a partir de transcrições oficiais", como faz a produção do canal Discovery Chanel;

- O título da obra também sugere o docudrama, sobretudo, quando se trata de reconstituições da vida de pessoas já falecidas em caráter póstumo (JFK) ou alusão a grandes catástrofes ou tragédias “Acidentes aéreos, voo 1904”.

Ressalvamos, no entanto, que essas instruções funcionam apenas como sugestão para que o leitor/espectador indicialize a leitura docudramentarizante porque

(...) assim como nos documentários, todo leitor tem a possibilidade, não importa em que momento do filme, de se ligar na leitura documentarizante. Sublinhamos, entretanto, que essa operação não pode sempre efetuar em qualquer nível; o filme tem, com efeito, o poder de interditar certos níveis; é assim que a exibição, nos créditos, da participação dos atores bloqueia a possibilidade de se construir personagens como enunciadores reais. Convém, entretanto, insistir sobre o fato de que um filme não tem jamais o poder de bloquear totalmente a leitura documentarizante; a qual pode sempre ao menos operar no nível da construção da câmera e/ou do cinema, como enunciadores reais. (Odin, 1984, p. 5). 
No nível do texto escrito, o docudrama manifesta-se num sistema de estilo do melodrama, principalmente:

- Lições ético-morais;

- Punição de um vilão ou exaltação de um herói;

- Preferências pela família como elemento predominante na história;

- Protesto contra injustiças sociais e apelo ao sentimentalismo.

\subsection{Docudrama em Linha Direta}

Antes de propor qualquer análise, convém esclarecer que compreendemos o docudrama como um grande texto audiovisual com combinações verbais e não verbais. A semiótica discursiva concebe o texto como sendo aquilo que é capaz de produzir efeitos de sentido em alguém ou, dito de outra maneira, capaz de criar um discurso sobre o mundo. Como nos ensina Barros (2000, p. 55): "Partindo do princípio de que todo discurso procura persuadir seu destinatário de que é verdadeiro ou falso, os mecanismos discursivos têm, em última análise, por finalidade criar a ilusão de verdade".

O programa Linha Direta, além de ajudar a colocar na cadeia foragidos da justiça, produziu duas séries especiais: Linha Direta Justiça e Linha Direta Mistério. Em Linha Direta Justiça foram produzidas Quatro histórias reais. Quatro crimes que chocaram o país. Tragédias que marcaram época. Em Linha Direta Justiça, dramaturgia e jornalismo se misturam para recontar os casos Fera da Penha, Dana de Teffé, Zuzu Angel e Angela Diniz. Quatro mulheres envolvidas em tramas de amor, poder, traição e violência ${ }^{69}$. No DVD A Maldição do Edifício Joelma e Outras Histórias, há três histórias que, se tivessem ocorrido no século XIX, certamente seriam publicadas na forma de fait divers: A primeira delas recebe o nome de $O$ Enigma do Edifício Joelma e o seguinte resumo enfoca o tema central do episódio: Centro de São Paulo, 1 de fevereiro de 1974. A cidade assiste a uma das maiores tragédias de sua história: o Edifício Joelma arde em chamas, deixando 189 vítimas fatais. Mas, por trás daquele incêndio, existia uma outra história misteriosa, conhecida por poucas pessoas.... Na segunda história, denominada de Operação Prato, é publicado o seguinte resumo: Em 1977, uma série de fenômenos levou pânico para pequenas cidades do litoral do Pará. Luzes que vinham do céu atacavam a população. A aeronáutica foi acionada e investigou o

69. Texto de divulgação da capa de divulgação do programa especial Linha|Direta Justiça. 
fenômeno. O resultado da missão até hoje é mantido em segredo pelas forças armadas. E Máscaras de chumbo fecha a séries de especiais sobre histórias misteriosas: Agosto de 1966. Dois corpos são encontrados no Alto Morro do Vintém, em Niterói - RJ. Os corpos são de técnicos em eletrônica da cidade de Campos, usando capas de chuva e duas estranhas máscaras de chumbo.

Como é notável, os assuntos tratados nesse programa seguem os moldes do gênero docudrama, elegendo como temática histórias extraordinárias: incêndios, assassinatos, aparição de seres extraterrestres. Os temas eleitos nestas reconstituições foram amplamente divulgados na imprensa escrita e em reportagens de televisão na época, o que acaba por ajudar o leitor/espectador a tomar essas temáticas como enunciadores reais. Com efeito, o reconhecimento do baseado em fatos reais já indica que essas produções têm a possibilidade de efetuar a leitura docudramentarizante. No entanto, deve-se esclarecer que não basta uma produção ser baseada em fatos reais para ser lida como docudrama. Na história recente da produção cinematográfica brasileira, podemos apontar três exemplos que ajudam a esclarecer a questão: o Última Parada Ônibus 174 (2008), Jean Charles (2008) e Lula, o Filho do Brasil (2010). Evidentemente, são três filmes que tomam fatos e personagens como enunciadores reais. O primeiro, dirigido por Bruno Barreto, é baseado na história real de Sandro do Nascimento, que acaba por fazer passageiros de uma linha convencional de ônibus no Rio de janeiro como reféns, fato que culmina na morte de uma das passageiras. Os momentos de grande tensão foram testemunhados e transmitidos ao vivo pelas redes de televisão. Em 2002, o diretor José Padilha fez um documentário sobre o mesmo assunto. O segundo, dirigido por Henrique Goldman, ganhou repercussão mundial após Jean Charles de Menezes, em 2005, ser confundido com terroristas e morto por policias britânicos no metrô de Londres. O terceiro, dirigido por Fábio Barreto, aborda a biografia de Luís Inácio Lula da Silva e reconstitui sua trajetória familiar desde sua terra natal, em Caetés-PE, até São Paulo, enfocando sua difícil relação com o pai e sua carreira como líder sindical à presidência da República. Nos três filmes, atores globais interpretam os personagens, diminuindo o efeito de realidade que atores não conhecidos poderiam causar. Com exceção de Jean Charles, que é interpretado por Selton Mello, ator global e protagonista de vários filmes de sucesso, os protagonistas de Última Parada e Lula são feitos por dois atores não conhecidos do grande público. Em Última Parada Ônibus 174, o personagem principal, Sandro do Nascimento, é interpretado por Michel Gomes, e em Lula, o Filho do Brasil , Lula é feito pele estreante Rui Ricardo 
Dias. Os dois atores carregam em seus traços semelhanças físicas com as personalidades retratadas. Destacam-se, ainda, no elenco de Lula, o Filho do Brasil, Glória Pires, sua filha Cléo Pires, Juliana Baroni, Lucélia Santos e Antônio Pitanga, conferindo à produção um tratamento de star system como nas clássicas produções norte-americanas.

Os três filmes tomam como enunciadores reais temáticas-alvo dos fait divers e dos docudramas: sequestros, assassinatos e histórias de superação reconstituídas em caráter biográfico. Tomam, também, personagens como enunciadores reais: Sandro do Nascimento, Jean Charles de Menezes e Luís Inácio Lula da Silva, respectivamente. Essas marcas textuais indicializam o docudrama. No entanto, defendemos que não o são. Tratam-se apenas de ficção baseada em fatos reais. O docudrama vai além da ficcionalização ou dramatização de fatos reais: no gênero há uma intensa preocupação com um trabalho de ancoragem que pode ser desempenhado por repórteres ou apresentadores ou, ainda, por narração em off, quando o docudrama se aproxima de reportagens jornalísticas, a exemplo de Linha Direta e Por Toda Minha Vida, e de referente (fotografias, imagens de arquivo, depoimentos, etc) misturado com a narrativa de ficção.

No docudrama, há uma evidente preferência em utilizar atores não conhecidos, mas $\underline{\mathbf{0}}$ uso de atores profissionais não impede que uma obra seja lida como docudrama. Em JFK, A Lista de Schindler e Em Nome do Pai há a utilização de atores renomados. Entretanto, é possível observar que nessas obras, da forma como o discurso é construído pela montagem, o leitor/espectador, muitas vezes, não consegue discernir quais imagens são "reais" e quais são recriadas. Há uma evidente mistura, combinações e efeitos, como a imagem em preto e branco no início do filme $J F K$ e em toda a obra de A Lista de Schindler, que levam à construção desta sensação de combinação entre o referente (imagens de arquivos, fotografias) e a encenação.

Todos esses esforços de construção da narrativa constroem o que podemos chamar de efeitos de realidade. Por efeitos de realidade ou de referente entendem-se as ilusões discursivas de que os fatos contados são coisas ocorridas, de que seus seres são de carne e osso, de que o discurso, enfim, copia o real. (Barros,2000, p.59)

Mas, afinal, o que caracteriza de fato uma obra audiovisual como docudrama? O que torna Linha Direta e outros filmes aqui citados como docudrama e impede que outras obras, a exemplo de Última Parada Ônibus 174, Jean Charles $^{70}$ e Lula, o Filho do Brasil, sejam lidas 
como docudrama? Todas essas obras fazem com que o leitor/espectador tomem os fatos como enunciadores reais, utilizam-se de ingredientes clássicos do melodrama. Dito de outra maneira, há evidências da hibridação entre o documental e melodramático que acabam por sugerir o docudrama.

O que há em Linha Direta e que falta em Última Parada Ônibus 174, Jean Charles e Lula, o Filho do Brasil é o intensivo uso de referentes em forma de fotografia, manchetes de jornais, depoimentos, imagens de arquivo gravadas em formatos domésticos ou profissionais. Em Lula, o Filho do Brasil, há imagens de arquivo das lutas sindicais de Lula misturadas com a ficção da metade do filme até o final da obra, mas notamos uma ausência quase absoluta de referentes na parte inicial do filme. Nota-se que no docudrama "esses elementos ancoram o texto na história e criam a ilusão de referente e, a partir daí, de fato verídico, de notícia verdadeira” (Barros, 2000, p. 60). E mais, esses elementos aparecem frequentemente na montagem ou na edição e não esporadicamente. A foto de Jean Charles só aparece no final junto com os créditos na forma de homenagem dos realizadores; no Ônibus 174, a imagem de arquivo do fato é utilizada em raros momentos da obra; todo o resto são fatos transformados em tramas, o que nos leva a ler estas obras como ficção baseada em fatos reais e não como docudramas. Nesses filmes, apontamos características que fazem referência ao real (baseado em fatos reais), elementos de ficcionalidade (encenação, dramatização) e melodrama (vitimação de um personagem e punição de um criminoso). Entretanto, em ambos os filmes, notamos uma ausência quase absoluta de referente (fotografias, imagens de arquivo, etc) e, em consequência, avançamos na hipótese de que os docudramas ancoram na história elementos concretos na forma de tiras de jornais, relatos ou depoimentos, com o objetivo de assegurar a autenticidade dos fatos, ao mesmo tempo que recorre a elementos da ficção para encenar os fatos nos quais não foi possível registrar imagens. Há, portanto, uso frequente de referentes externos à obra. Para ilustrar essa proposta de leituras de docudramas, aplicaremos este raciocínio em um dos episódios de Linha Direta para verificar em qual medida esta proposta de leitura se sustenta.

Como afirmamos anteriormente, o reconhecimento de um fato real como enunciador real é condição indispensável ao gênero. No episódio $O$ Enigma do Edifício Joelma, por

Jean Charles pela polícia de Londres. A produção prevê gravações no apartamento onde Jean Charles vivia e pretende mostrar a sucessão de erros que levaram a polícia londrina a confundir Charles com o terrorista Hussain Osman. Disponível em: http://oglobo.globo.com/cultura/kogut/posts/2008/12/19/tv-inglesa-fazdocudrama-sobre-jean-charles-148315.asp, acessado em 14/03/2010. 
exemplo, o leitor/espectador, de antemão, já sabe que se trata de uma produção audiovisual baseada em fatos reais, tanto pela característica básica de Linha Direta que já se enuncia como baseado em fatos reais, quanto pela ampla divulgação do fato na época do ocorrido em fevereiro de 1974 - e anos posteriores à tragédia, porque, mesmo aqueles que nasceram depois do fato, provavelmente, já ouviram comentários a respeito de um incêndio que é considerado uma das piores tragédias ocorridas na história da cidade de São Paulo. Dito de outra forma, quase quarenta anos após o incêndio, o assunto ainda é atual como as páginas de um típico fait divers:

É interessante notar que, num jornal, a página de fait divers é a única que não envelhece. Se é impossível, hoje, ao ler um jornal antigo, compreender algum fato político sem recorrer ao contexto, sem apelar para nosso conhecimento histórico, a leitura de um fait divers ainda pode, cem anos depois, causar os mesmos arrepios ou espantos. O relato desse tipo de crônica se caracteriza por sua intemporalidade e constitui uma informação imanente, total, que contém em si mesma todo seu saber. (Meyer, 1996, p. 99)

As primeiras imagens desse docudrama são representadas por cenas que focalizam o edifício Joelma na contemporaneidade, deixando claro ao espectador que o prédio, palco da tragédia, ainda existe. Fusão para um cemitério e inserção do crédito; Cemitério São Pedro São Paulo, 1990. Nessa perspectiva, a inserção de caracteres com datas em locais colabora para a construção do efeito de realidade. Especificar e concretizar o tempo, o espaço e os atores do discurso são elementos "que ancoram o texto na história; (...) a mesma função podem ter as fotografias que acompanham as notícias. O papel ancorador da fotografia é assegurado pela crença ideológico-cultural no seu caráter analógico de 'cópia do real'". (Barros, 2000, p. 60-61). Na sequência, a produção segue para o campo da ficção, onde atores não conhecidos interpretam uma cena no cemitério no qual ouvem gritos e um dos túmulos pega fogo. Nota-se a inserção do lettering Simulação, que acaba por estimular o espectador a ler a cena como ficção e, portanto, se recusar a construir um enunciador real. Uma narração é inserida: Luiz Nunes, o zelador do cemitério, tenta localizar de onde vêm os gritos. Reconhece-se, aqui, a voz de Carlos Vereza, um consagrado ator de telenovelas ocasionando uma evidente mistura entre o real e o ficcional, já que supostamente o locutor está narrando fatos supostamente reais, mas é reconhecido como ator. 
Carlos Vereza (locução): Surpreendentemente, quando Luís joga água nos túmulos os gritos silenciam. Para Luis Nunes, os gritos saíam daqui, do túmulo de 13 pessoas que morreram queimadas numa das maiores tragédias da cidade de São Paulo, o incêndio do edifício Joelma. Entre centenas de vítimas, esses 13 corpos jamais foram identificados. Os 13 corpos deram origem ao mistério das 13 almas, um dos enigmas que até hoje ronda o Edifício Joelma.

Domingos Meirelles (apresentador): Boa noite, começa hoje o Linha Direta Mistério, uma série de reportagens sobre fatos intrigantes e assustadores que a ciência dificilmente consegue explicar. Agora você vai entrar numa outra dimensão da história do Edifício Joelma, na época um dos mais imponentes prédios de escritórios do centro de São Paulo. Em 1974, o Joelma ardeu em chamas por mais de 4 horas, foram 345 feridos e 189 mortes numa tragédia que parou o Brasil, mas por trás dessa tragédia há um enigma.

A forma como Meirelles apresenta o texto de abertura do programa foi construída nos moldes de uma reportagem de televisão, aproximando-se de programas tipicamente jornalísticos, como o Globo Repórter.

O texto jornalístico, tradicionalmente, busca construir discursos com efeitos de objetividade e manter a enunciação afastada do discurso, criando uma espécie de imparcialidade no relato da informação. Entretanto, esse distanciamento entre o enunciador e o enunciatário é uma ilusão, já que o enunciador faz suas escolhas e conduz o texto para um determinado caminho, o que acaba por levar o leitor a crer em suas opiniões. Portanto, essa ilusão de afastamento (objetividade) é fabricada por mecanismos discursivos, o que faz com que o texto jornalístico seja construído em terceira pessoa (função referencial ou informativa da linguagem para Jakobson). Quando escrevemos o presidente Luis Inácio Lula da Silva anunciou aumento ao salário mínimo produzimos efeito de objetividade, já que o uso da terceira pessoa cede a voz diretamente para os envolvidos na informação. Os documentários cinematográficos, tradicionalmente, produzem efeitos de objetividade, pois se preocupam com o relato do fato histórico de maneira mais fiel possível sem criar tramas em cima disso.

Há dois efeitos básicos produzidos pelos discursos, com a finalidade de convencerem de sua verdade: 
1. Proximidade (efeito de subjetividade) e distanciamento (efeito de objetividade);

2. Realidade ou referente

Carlos Vereza (narrador) Até hoje, 31 anos depois do incêndio, especialistas garantem que o lugar é cercado por uma estranha energia espiritual; segundo testemunhas, o Edifício Joelma carrega uma maldição. Para tentar entender como maldição, vamos voltar no tempo e investigar a história do lugar. Onde hoje é o Edifício Joelma, antes existia uma casa, nela vivia o professor de química Paulo Ferreira de Camargo.

$\mathrm{Na}$ edição, o texto do narrador é interrompido e depoimentos são inseridos: Georges Charbel (radiestesista), José Carlos Pinheiro (ex-encarregado do estacionamento) e Renato Sabbatini (neurocientista), respectivamente, cujos relatos ajudam o narrador a ancorar os fatos, auxiliando a criar o esperado efeito de realidade. Somam-se as diversas cenas (fotografias, imagens de arquivo do edifício pegando fogo e páginas de jornais e revistas da época) para reforçar o referente.

$\mathrm{E}$ as informações que funcionam como referente continuam. A edição acrescenta o lettering São Paulo - Outubro de 1948. Entra simulação, onde Paulo Ferreira de Camargo mata a mãe e as duas irmãs jogando os corpos em um poço e se mata. A edição do docudrama sugere que o local é assombrado e que o incêndio aconteceu em um local amaldiçoado. Misturadas com as encenações, fotografias da casa que existia no local são inseridas juntamente como uma página de jornal, na qual constam as fotografias do assassino/suicida e de sua família. Há uma evidente relação de coincidência com a repetição do acontecimento.

Os suicídios repetidos em um mesmo lugar contribuirão para tornar este lugar suspeito, até mesmo mal assombrado. Do mesmo modo, após uma sequência de acidentes numa estrada, esta será batizada, no todo ou em parte, de "estrada da morte", tornando, assim, a estrada responsável por todos estes acidentes fatais. (Dion, 2007, p. 129)

Carlos Vereza - locução: O mistério da morte de toda a família nunca foi desvendado. No resgate dos corpos, um bombeiro morreu vítima de infecção cadavérica. O triplo assassinato seguido de um suicídio abalou a população de São Paulo e ficou conhecido como o crime do poço. O lugar ganhou fama de mal assombrado.

Durante a locução, imagens do resgate dos corpos de jornais antigos são inseridas.

Domingos Meireles - em frente ao Edifício Joelma - Exatamente aqui nesse lugar 
ficava a casa do professor Camargo no número 104 da rua Santo Antônio. Em 1972, a casa foi demolida e construíram no lugar o prédio de linhas modernas para a época: o Edifício Joelma; eram 20 andares ocupados por escritórios de um banco, nos seis pavimentos interiores ficava o estacionamento. Chegaram até a mudar o número do prédio, mas a maldição nunca foi esquecida.

$\mathrm{Na}$ reconstrução da realidade ou referente, tanto o documentário, quanto o docudrama recorrem a um recurso semântico denominado de ancoragem.

Trata-se de atar o discurso às pessoas, espaços e datas que o receptor reconhece como "reais" ou "existentes", pelo procedimento semântico de concretizar cada vez mais os atores, os espaços e o tempo do discurso, preenchendo-o com traços sensoriais que os "iconizam", os fazem "cópias da realidade". (Barros, 2000, p. 60)

Nesse caso, a figura de Domingos Meirelles funciona como âncora e em seu texto a especificação de "onde" e "quando" é fundamental para que cause no leitor/espectador a sensação de autenticidade desses dados.

Na sequência, há inserção de uma fotografia do edifício antes do incêndio e do lettering: Edifício Joelma são Paulo, 1974 e dramatização com cenas de reconstituição (lettering: simulação).

Carlos Vereza (locução): Por dia, mais de mil pessoas circulam pelo Joelma. A processadora de dados Volquimar, 21 anos, e o irmão Álvaro trabalham no banco que fica no prédio.

Walkyria de Carvalho (mãe de Volquimar), uma criança normal graças a Deus! Muito inteligente. Cursou o primário, o ginásio e formou-se professora aos 17 anos. Entra Insert de fotografia de Volquimar criança e em outra, adolescente. Nota-se claramente que a produção de Linha Direta selecionou a atriz que interpretou Volquimar pelas fotos, dadas as evidentes semelhanças. Tal recurso é bastante recorrente no gênero docudrama, quando para o espectador está claro que as imagens são encenações, mas que é muito importante manter-se o efeito de realidade, uma vez que os atores não são conhecidos do público e que, portanto, cria-se uma sensação de que aquelas pessoas são de "carne e osso" e poderiam ser encontradas em qualquer situação.

Carlos Vereza: Sexta-feira, oito da manhã. Vigésimo terceiro andar. (entra simulação, na qual Volquimar está conversando com colegas de trabalho, demonstrando-se feliz por ter 
passado no vestibular) Quatro andares abaixo de Volquimar estava a secretária Nádia Carderelli (sobrevivente).

Repórter: Você teve algum pressentimento, alguma coisa assim?

Nádia Carderelli - Foi muito gozado porque minha mãe teve. Ela acordou me chamou e ela falou parece que você vai se casar com um médico, eu sonhei com você abraçada com dois homens de branco. Aí eu saio, atravesso a rua, ela fala: não vai trabalhar hoje não, fica em casa, pra gente bater papo. Umas coincidências, só isso. Por outro lado, há outros mecanismos que buscam manter a enunciação próxima do discurso (garantia de parcialidade/proximidade ou subjetividade), criando efeitos de subjetividade como, por exemplo, o uso da primeira pessoa do discurso (função emotiva para Jakobson).

Elementos da língua como "eu", "aqui", "agora" possuem um significado linguístico estável e geral que alude respectivamente a uma pessoa, a um lugar, a um tempo, mas dentro de cada enunciado eles remetem à situação específica e individual da enunciação. (Volli, 2007, p. 137).

Carlos Vereza: oito e quarenta e cinco da manhã, um curto-circuito no ar condicionado é o primeiro sinal da tragédia.

Roberto Lemes (Coronel da PM que participou do resgate). As ligações do ar condicionado passavam embaixo dos forros. Esses forros eram de material combustível, então a propagação do calor foi muito rápida. Como é evidente, tanto os documentários como as reportagens de televisão e os docudramas buscam ceder a voz para especialistas de áreas que explicam e atestam tecnicamente o porquê das coisas. Naturalmente, esse recurso estimula o leitor/espectador a reconhecer como enunciador real o responsável pelo discurso e toma como verdade as argumentações expostas.

Seguem sequências de cenas onde os funcionários, que estavam no interior do edifício, se dão conta de que o prédio está pegando fogo e ficam em pânico. Na edição, são inseridas imagens reais de arquivo do Joelma pegando fogo. Umas das marcas registradas de Linha Direta é o de conduzir o olhar do espectador, informando a ele o momento onde as cenas devem ser lidas como ficção e outras como "realidade". Nas reconstituições, como vimos, é inserida a informação simulação, e nas inserções de cenas "reais" é inserido o lettering: Arquivo.

Carlos Vereza: Sem ter para onde fugir, as pessoas entram em pânico. O calor chega a setecentos graus centígrados. (Entram sequências de imagens de arquivo dos bombeiros 
tentando o resgate e pessoas se atirando do prédio). A informação de temperatura reforça a relação de causalidade e aumenta a sensação de espanto com o reforço da surpresa de um número.

Sérgio Motta Mello (Jornalista que cobriu o incêndio) Foi um espetáculo dramático né? As pessoas olhando, desesperadas, procurando parentes

Nádia Carderelli- Não tinha outra coisa a se pensar. Era só a morte ali chegando, não tinha outra alternativa, você ia escapar por onde? Pular não dá...

Carlos Vereza: O sofrimento é insuportável. Desesperados, muitos se jogam do prédio. (Entra uma montagem híbrida entre a ficção e realidade, simulando um ator na parte interna do prédio se jogando e corta para parte externa do edifício com imagens reais de um homem pulando) - Cartazes com pedidos pra que as pessoas não saltem do prédio são escritos, mas pouco adianta.

Carlos Vereza - Sobreviventes do incêndio do Joelma não esquecem aquela manhã de horror.

Nádia Carderelli - Como é que eu consegui sobreviver? O estado que eu estava, eu estava em um estado lastimável. Eu notei que um helicóptero desceu, um bombeiro se abaixou, as pessoas que estavam melhor ajudaram as outras a subir. Falei, bom, existe uma chance ali, aí Deus me deu uma força tão grande, não sei de onde veio, eu tava com meu pé inteirinho queimado. Fiquei de pé, fui lá, implorei para o bombeiro, ele disse 'fique aí quietinha que da próxima vez vai ser você'.

Repórter: o que você sente assim quando você passa de frente ao Joelma, qual o sentimento?

Nádia Carderelli - Ainda me dá um arrepio, até hoje um calafrio.

Repórter: Você chegou a entrar de volta no prédio?

Nádia Carderelli - Não, nunca mais.

Carlos Vereza (locução): Volquimar e as amigas não sobrevivem ao incêndio. Horas depois o corpo de Volquimar é encontrado pelo irmão no Instituto Médico legal - entra simulação - Álvaro não tem coragem de contar que a irmã está morta. Mas, segundo a mãe dela, Volquimar reaparece. Walquyria ( mãe de Volquimar) pede ajuda ao médium Chico Xavier para se comunicar com a filha. Os espíritos de dois poetas teriam contado a Chico Xavier que as vítimas do incêndio do Joelma eram reencarnações de mortos do século XI nas batalhas das cruzadas para a conquista cristã de Jerusalém. Segundo testemunhas, 
Volquimar através de cartas psicografadas pela mão do médium esclareceu como foi a própria morte e a passagem para a vida espiritual.

A partir de então, o docudrama enfoca a história de Volquimar, que tentou estabelecer contato com sua família, marcando a data de 13/07/74 em Uberaba - MG, para que a mãe procurasse por Chico Xavier, ocasião que ela mandaria um recado. Volquimar manda mensagem através de uma carta psicografada que é publicada nos jornais da época.

A partir das cartas psicografadas por Chico Xavier, foi escrito um roteiro que deu origem ao filme Joelma, $23^{\circ}$ Andar, no qual a atriz Beth Goulart interpretou o papel de Volquimar. O docudrama Linha Direta relata alguns fenômenos estranhos que aconteceram durante as filmagens. Entre eles, a aparição de rostos estranhos na fotografia da cena em que as atrizes estavam interpretando as mortes dos personagens retratados, uma evidente relação de causalidade que foca fatos inexplicáveis com os recorrentes "mistérios do céu" bastante comuns nos fait divers e nos docudramas ${ }^{71}$.

Domingos Meireles (passagem) - Depois do incêndio, o Edifício Joelma ficou durante quatro anos fechado para reformas. Quando foi liberado e voltou a funcionar, passou a ser considerado um dos prédios mais seguros da cidade. Foi inclusive rebatizado com um outro nome, passou a se chamar Praça da Bandeira. Em 1994, a prefeitura encontrou algumas irregularidades como excesso de carga na energia e falhas no sistema de emergência, mas logo foi tudo resolvido. Mas, segundo testemunhas, os espíritos dos mortos ainda vagam por aqui.

Há uma série de depoimentos de ex-funcionários do prédio que relatam fenômenos estranhos no edifício, intensificando o tom de mistério trabalhado no episódio.

Carlos Vereza (locução): - Muitas empresas que tinham escritório no Joelma abandonaram o prédio. Em 2004, responsáveis pelo comitê de transição da equipe do prefeito José Serra passam a usar uma sala do prédio pouco antes de ele assumir a prefeitura de São Paulo. Por prevenção, eles chamam uma monja budista para purificar o local... Hoje, o antigo Joelma tem dezenas de salas vazias. Entre elas, a sala onde Valquimar trabalhava. O incêndio provocou uma ampla discussão sobre a lei de segurança dos prédios e foram

71. Ver a programação do canal a cabo Discovery Channel, no qual programas sobre mistérios ocupam boa parte dos programas: Mundo espiritual, parapsicologia, os mais assombrados, guia caça-fantasmas e as histórias mais estranhas de ovnis de todos os tempos são alguns deles. Segundo a grade de programação disponível em http://www.discoverybrasil.com/guia_paranormal/paranormal_mundo_espiritual/paranormal_historia_fantas mas/index.shtml, acessado em 10/01/2010. 
criadas normas de prevenção em São Paulo. Cinco pessoas foram responsabilizadas pela falta de segurança no Joelma. Todas foram condenadas. Como eram réus primários, conseguiram recorrer e nunca foram presas. Os atuais administradores do edifício não quiseram gravar entrevista e a tentativa de livrar o Joelma dos supostos espíritos continua.

Domingos Meireles - As histórias em torno do antigo Joelma ainda são um grande mistério. Uns não acreditam, outros duvidam e alguns têm certeza de que tudo é verdade. E você?

Em suma, nesse episódio do programa Linha Direta, o leitor/espectador é estimulado a operacionalizar a leitura docudramentarizante, reconhecendo como enunciadores reais: 1. o fato histórico em sim - o incêndio do edifício Joelma. 2. Personagens - história centrada na morte de processadora de dados Volquimar. Sua vida é reconstituída desde a infância através de depoimentos de sua mãe. 3.Cameraman- nos depoimentos e relatos, os entrevistados olham diretamente para câmera confirmando a existência de uma equipe de audiovisual naquele local e naquele momento. 4. Âncora/apresentador - narra a história em terceira pessoa, por vezes vai até o local para atestar a autenticidade das imagens e dos fatos em si e $\mathbf{5}$. Responsáveis pelo discurso - entrevista de bombeiros que explicam tecnicamente as causas da tragédia, de um radiestesista e de um neurocientista. Ao mesmo tempo que o leitor/espectador toma como "verdade" esses enunciadores "reais", o texto provoca a leitura fictivizante na medida em que produz uma encenação e instrui a leitura por parte da audiência, acrescentando o lettering: simulação. Durante o episódio, diversos referentes são trabalhados, aumentando, assim, o efeito de realidade: São Paulo, 1974, 8 h30 da manhã, fotos e imagens de arquivo. Elementos melodramáticos são evidenciados na narrativa através da representação dos familiares e da comoção diante do ocorrido. Há a sugestão da punição de "vilões": Cinco pessoas foram responsabilizadas pela falta de segurança no Joelma. Todas foram condenadas. Como eram réus primários, conseguiram recorrer e nunca foram presas. Fica no ar sugerida a impunidade ou descaso e injustiça em relação à tragédia e, por fim, nota-se o caráter efêmero, espantoso, sensacionalista e imanente herdados dos fait divers e comumente atribuídos ao gênero.

Essa estrutura híbrida entre o ficcional e o documental ou do documento com o drama é que torna possível a compreensão do gênero docudrama, ambíguo por excelência, o que torna a tarefa de classificar o gênero ainda mais complexa. Em outras palavras, insistimos na ideia de que não basta um filme ou um programa ser "baseado em fatos reais" para ser 
categorizado como docudrama. Há toda uma conexão entre estruturas clássicas do documentário e o melodrama, que deve ser avaliada na compreensão do gênero.

\title{
2.6 Docudrama em Por Toda Minha Vida.
}

Conforme já havíamos anunciado na introdução do presente capítulo, Por Toda Minha Vida é um docudrama que, assim como Linha Direta, representa o gênero na televisão brasileira:

\begin{abstract}
Por toda minha vida reconta a biografia de compositores e intérpretes da música popular brasileira já falecidos, misturando documentário e dramatização. $\mathrm{O}$ formato inclui imagens de arquivo, trechos de shows, depoimentos de amigos, parentes e pessoas que conviveram com o personagem retratado, visita a lugares onde o biógrafo esteve, além das reconstituições de momentos relevantes na vida de cada um. Os roteiros são baseados nos fatos da vida real dos cantores e músicos, a partir dos fatos narrados por quem os conhecia. ${ }^{72}$
\end{abstract}

Como os tradicionais docudramas, o especial dos Mamonas Assassinas tem em seu elenco atores não conhecidos do grande público mas que guardam semelhanças físicas com os cantores retratados:

\footnotetext{
Um destaque do programa é a escolha do elenco: a produção se esforça para encontrar atores que sejam sósias idênticos dos protagonistas. $\mathrm{O}$ ator Charles Mais, nome artístico do intérprete de Tim Maia, por exemplo, é um excozinheiro paulista que ganhava a vida fazendo cover do cantor carioca. Por outro lado, Hermila Guedes já era uma atriz premiada pelo filme O céu de Suely, quando viveu Elis Regina. E Bruce Gomlevsky estava em cartaz há mais de um ano com a peça biográfica sobre Renato Russo ao ser escalado para interpretar o mesmo papel no programa ${ }^{73}$.
}

Logo no início do programa, o espectador já é estimulado a reconhecer o fato em si como enunciador real. A edição insere imagens de arquivo de shows, intercaladas com entrevistas de familiares e dos produtores do grupo. Na sequência, a legenda: Brasília, 2 de março de 1996.- último show dos Mamonas Assassinas funciona como referente, pois atesta o fato como verdadeiro, localizando-o no tempo e no espaço. Uma proposital mistura entre as

\footnotetext{
72. Segundo sinopse do programa disponível em: http://memoriaglobo.globo.com/Memoriaglobo/0,27723,GYN0-5273-258725,00.html, acessado em $23 / 03 / 2010$ 73. Idem.
} 
imagens reais de arquivo deste último show com as da ficção, na qual atores simulam o que teria, de fato, acontecido naquele último dia, completa as características fundamentais do gênero. Com efeito, o espectador é estimulado a realizar a leitura docudramentarizante logo no início da produção, que combina referentes e ficção: um ator, intérprete de Dinho, apresenta cada integrante da banda, fotografias são inseridas. Inserção do lettering: uma hora e quarenta minutos antes do acidente. Simulação do grupo entrando no avião rumo a Guarulhos.

Assim como em Linha Direta, um apresentador funciona como âncora dos fatos que são narrados de maneira linear, recorrendo ao histórico de vida dos integrantes do grupo:

Fernanda Lima: Samuel Reoli era office boy, seu irmão Sérgio tinha uma locadora de vídeo game, Bento vendia ração, Júlio era técnico em eletrônica e Dinho, cabo eleitoral. Mas a paixão pela música mudou de forma radical a vida desses meninos. Com mais de dois milhões de cópias vendidas de um único álbum, eles bateram todos os recordes, conquistaram crianças e adultos e tornaram o ano de 95 muito mais divertido. Mas essa alegria durou pouco; foram sete meses de um estrondoso sucesso interrompido por um trágico acidente. Sozinhos, eram cinco garotos como tantos outros, mas juntos tornaram-se o fenômeno Mamonas Assassinas.

Como num tradicional fait divers, a representação da morte trágica dos Mamonas Assassinas é efêmera, espantosa e sensacionalista. Chama atenção no texto de abertura lido pela apresentadora o que Barthes (2009) chama de surpresa dos números, na qual um pequeno número é capaz de causar consequências de grandes proporções: Com mais de dois milhões de cópias vendidas de um único álbum (...) foram sete meses de um estrondoso sucesso interrompido por um trágico acidente.

O docudrama dos Mamonas Assassinas segue com as características fundamentais do gênero, inserindo datas e locais como referente: Guarulhos, março de 1989 e simulação, através da ficção, do que cada integrante fazia antes do estrondoso sucesso. Imagens de baixa qualidade técnica, em VHS, da banda ensaiando antes de se tornar amplamente conhecida reforçam o efeito de realidade. Além dos referentes-fotografias, imagens de arquivo e depoimentos - o programa permite a operação da leitura fictivizante - segunda categoria do docudrama - ao encenar as situações relatadas através dos depoimentos.

Fernanda Lima: Com cinco anos de estrada, a Utopia era uma banda de rapazes bem humorados que cantavam músicas baixo astral. Mas foi aqui no conhecido Parque Cecap que 
a história começou a mudar. Em setembro de 1994, os meninos foram contratados para cantar num comício e foi nesse sábado que eles receberam um desafio de inventar algo novo no encerramento de uma campanha política. E eles toparam.

Na sequência, o programa reconstitui toda a trajetória da banda: Insert da legenda: 24 de setembro de 1994: encenação do grupo no caminho do comício compondo as músicas que acabariam por se tornar grandes sucessos. A edição do programa mistura imagens da ficção, reconstituindo o show com imagens de arquivo do grupo se apresentando em programas de auditório da época, como o Xuxa Hits e Domingão do Faustão.

Boate Lua Nua - Guarulhos 7 de abril de 1995. O Grupo apresenta seu repertório musical para um alto executivo de uma gravadora. Encenação misturada com imagens de aquivo. A locução de Fernanda Lima informa que o primeiro disco dos Mamonas Assassinas foi lançado no dia 23 de junho de 1995.

Fernanda Lima: Pros Mamonas Assassinas, o ano de 1995 foi inacreditável. De meninos simples e anônimos, eles se transformaram em estrelas da música pop. Mas o ano seguinte se anunciava ainda mais brilhante: um novo disco estava a caminho assim como um novo show muito especial. Em janeiro, o quinteto de Guarulhos voltou ao ginásio Pascoal Thomeu onde há anos havia sido rejeitado. Mas, dessa vez, eles subiram o palco como heróis. Insert da legenda: Estádio Pascoal Thomeo - "Thomeozão" - 6 de janeiro de 1996. Encenação do grupo no camarim se preparando para entrar no show. Mistura com imagens de arquivo em vhs.

Fernanda Lima: No dia 02 de março de 1996, véspera da tão aguardada viagem a Portugal, o sábado amanheceu chuvoso em Guarulhos. Samuel, Sérgio, Bento,Dinho e Julio estavam exaltados e queriam aproveitar o dia de folga ao lado dos seus familiares. Mas eles tinham um compromisso a cumprir: um show no Mané Garrincha em Brasília.

Uma sequência de encenações representando o que teria sido último dia de cada um dos cinco integrantes do grupo na manhã do dia do acidente é inserida no programa. Dentre essas encenações, chama atenção a de Júlio pelo seu caráter sobrenatural: os créditos reforçam o referente: dia do acidente $12 \mathrm{~h} 41 \mathrm{~m}$. Júlio está no cabeleireiro e este, ao final do corte de cabelo, grava imagens do artista através de uma câmera de vídeo caseira. As imagens da ficção são misturadas com as de arquivo deste mesmo dia onde Julio se mostra preocupado e diz: Tchau pessoal, vou embora. (cabeleireiro: Falou Júlio, boa viagem) Não sei, essa noite eu sonhei com um negócio assim, parecia que o avião caía.. Eu não sei, não sei o que quer 
dizer isso. (cabeleireiro: Vou rezar por você hein, vou rezar). A autenticidade da imagem de arquivo pode ser reforçada pela diferença da qualidade de imagem que, evidentemente, foi gravada em suporte diferente e de baixa resolução de imagem se comparada com a da ficção. Além disso, o espectador consegue diferenciar a imagem "real" com a da ficção através da evidente diferença de continuidade evidenciada na produção: nas imagens "reais", Júlio usa brincos nas duas orelhas e o ator que o representa na ficção não usa. São detalhes que ajudam o espectador a ler o que é simulação e o que é imagem de arquivo "real". O pressentimento de Júlio ou a suposta "pré- visão" do acidente foi amplamente explorado pela imprensa da época e a ênfase dada a este acontecimento no docudrama cumpre a função de reforçar o caráter espantoso e inexplicável, conforme pontuado por Barthes (2009), geralmente trabalhado nos fait divers e herdado pelos docudramas. $\mathrm{O}$ efeito de realidade é reforçado pelo depoimento de Juliano Barbosa, pai de Júlio que, ao analisar as imagens com o suposto pressentimento do acidente pelo filho, afirma: - quando ele coçava a nuca é porque ele tava preocupado, ele tinha esse detalhe, então pode ver na fita que ele fala e coça nuca, então é uma preocupação dele.

Uma das hipóteses da causa do acidente é sugerida no docudrama: Legenda: Uma hora e vinte minutos antes do acidente. O grupo embarca no avião. Há uma simulação na cabine do avião em comunicação com a torre de controle, na qual a instrução era para que a aeronave arremetesse para o setor sul. O comandante entendeu setor norte, ocasionando o acidente.

Outro recurso comum nos docudramas é utilizar arquivos de telejornais como forma de assegurar a autenticidade dos fatos reconstituídos. No caso dos Mamonas Assassinas, Por Toda Minha Vida inseriu imagens de arquivo do Programa Fantástico, apresentado na época por Fátima Bernardes e Celso Freitas:

Fátima Bernardes: - O jatinho em que os cinco viajavam despedaçou-se na noite de ontem contra a serra da Cantareira em São Paulo.

Celso Freitas: - Estão mortos todos os integrantes do irreverente grupo Mamonas Assassinas, o maior fenômeno da história recente da música brasileira.

Uma montagem com fotos do grupo e cenas de arquivo do enterro na qual observa-se uma multidão de pessoas chorando e o depoimento de Eduardo Bueno, biógrafo da banda, reforça a efemeridade do fato retratado no docudrama: da explosão, do lançamento do disco $e$ 
do clipe, a morte deles, são cinco meses e três semanas, é inacreditavelmente efêmero, é muito injusto, não era pra durar tão pouco assim.

Fernanda Lima: Mais de dez anos depois do acidente e as causas que levaram à queda do avião aqui na Serra da Cantareira ainda não foram totalmente esclarecidas, mas a lembrança que permanece é da alegria dos meninos de Guarulhos. Com eles, o Brasil inteiro foi mais feliz.

No final do docudrama, um clipe com música instrumental ao fundo de "Pelados em Santos" reforça o caráter melodramático da produção que homenageou o grupo com uma edição de imagens que misturou fotografias antigas de cada um dos integrantes ainda crianças e bebês, com depoimentos emocionados de seus familiares.

\subsection{Exemplos de filmes que podem ser lidos como docudramas}

A seguir, ilustramos alguns filmes nos quais é possível realizar a leitura docudramentarizante: Voo United 93 (EUA, 2006), Boa Noite e Boa Sorte (EUA, 2005), Bobby (EUA, 2006) e Nixon (EUA, 2005).

Voo United 93 (2006), dirigido por Paul Greengrass, conta o drama dos passageiros e da tripulação que viveram intensos momentos de horror em um dos quatro aviões sequestrados em 11 de setembro de 2001, fato histórico que se manifesta como principal enunciador real. O filme reconstitui o que supostamente ocorreu na aeronave naquele fatídico dia. O roteiro é baseado nos relatos dos familiares que receberam diversas ligações telefônicas dos passageiros momentos antes de o avião cair. Todos os atores que interpretaram os passageiros conheceram os familiares e tiveram contato com a história de vida das vítimas através de matérias de arquivos pessoais, como vídeos, fotos e relatos dos familiares. Durante as dramatizações, atores da ficção observam as imagens reais das torres gêmeas em chamas. As imagens transmitidas ao vivo pela televisão (CNN) são incluídas na montagem do filme, resultando numa mistura entre ficção e realidade típicas dos docudramas. A obra não trabalha com o esquema de star system ajudando a construir o esperado efeito de realidade. As informações finais do filme funcionam como instrução para que o espectador leia o texto como enunciador real, conforme ilustramos abaixo: 
atingiu seu alvo. Ele caiu perto de Shanksville, Pennsylvania, Às $10 \mathrm{~h} 30 \mathrm{~min}$. Ninguém sobreviveu. Os militares só foram notificados que o United 93 foi sequestrado 4 minutos depois de ter caído. Os caças mais próximos estavam a $160 \mathrm{~km}$ de distância. Às $10 \mathrm{~h} 18 \mathrm{~min}$, o presidente autorizou os militares a interceptar qualquer avião sequestrado. Temendo abater alguma aeronave acidentalmente, os comandantes militares preferiram não passar a ordem aos pilotos no ar. Às $12 \mathrm{~h} 06$ min, todos os aviões civis sobre os Estados Unidos foram obrigados a aterrissar. Em uma mobilização militar sem precedentes, o espaço aéreo norte-americano ficou fechado até novas ordens. Em memória aos que perderam suas vidas em 11 de setembro de 2001.

Os nomes de todas vítimas são inseridos nos créditos finais ao lado dos atores que os interpretaram.

O filme Boa Noite e Boa Sorte (2005), dirigido por George Clooney, dramatiza a história real de Edward R. Morrow, âncora de TV que revela as táticas mentirosas do senador Joseph MccArthy na caça a supostos simpatizantes do comunismo. Com efeito, a biografia de Ed. Morrow é tomada como enunciador real e a leitura docudramentarizante pode ser operacionalizada com o auxílio de referentes representados por datas, locais e imagens de arquivo.

Logo no início do filme, os referentes de local e data são inseridos: Estúdios da CBS Nova York 14 de outubro de 1953 - ajudando a criar o efeito de realidade que é completado por um texto em movimento: Nas décadas de 1940 e 1950, os EUA estavam preocupados com a ameaça do comunismo. O senador Joseph Mccarthy fez uma denúncia pública, segundo a qual mais de 200 comunistas de carteirinha infiltraram no Governo. Poucos jornalistas dispuseram-se a confrontar Mccarthy, com o medo de tornarem-se alvo de suas acusações.

Na sequência, a obra segue com a ficção, mas sempre criando efeitos de realidade através da inserção de datas, imagens de arquivo e de anúncios de comerciais da época exibidos durante os intervalos do programa apresentado por Ed Morrow.

Tanto Voo United 93 quanto Boa Noite e Boa Sorte sugerem "vilões" que devem ser severamente punidos para que a ordem seja restabelecida. No primeiro caso, os vilões são os terroristas suspeitos pelos atentados de 11 de setembro; no segundo, a própria figura do senador Maccarthy. "Tudo segundo o melodrama clássico, a divisão da humanidade é simples e intangível: de um lado os bons, de outro os maus. Entre eles, nenhum compromisso possível", afirma Thomasseau (2005, p. 39).

Bobby - 22 Destinos. 1 Momento da História que Ninguém Vai Esquecer (2006), 
dirigido por Emilio Estevez, é baseado na história real do senador Robert Francis Kennedy (RFK) e candidato à presidência dos EUA. A trama gira em torno dos conflitos de 22 personagens que, na ficção, estavam no hotel no dia em que RFK foi baleado. Os personagens dramatizam os principais conflitos sociais e políticos da década de 1960 nos Estados Unidos, como o preconceito racial contra os negros e latinos (principalmente mexicanos), o uso de drogas pesadas (LSD) e dos casamentos arranjados que visavam livrar jovens americanos de serem convocados para a guerra do Vietnã. Como nos típicos docudramas, o filme, em seus créditos iniciais, inclui informações referenciais da situação social e política dos EUA nos seguintes termos:

1968 foi um ano de tumulto político e social nos EUA. Em 16 de março, Roberty F. Kennedy candidatou-se à presidência. Com uma plataforma, baseada na paz e na justiça, o senador nova-iorquino de 42 anos era visto como o candidato que poderia diminuir diferenças raciais e a esperança da nação para uma saída honrosa de uma guerra impopular.

Tal procedimento funciona como instrução para que o espectador leia a obra como sendo baseada em fatos históricos reais. O efeito de realidade é reforçado por uma sequência de imagens de arquivo, nas quais RFK anuncia sua candidatura à presidência dos Estados Unidos. Com o áudio original em off, o filme insere imagens reais da guerra do Vietnã. Na sequência, imagens fotográficas e em preto e branco de Martin Luther King, com áudio de RFK anunciando sua morte: Uma notícia muito triste para todos vocês. E, penso eu, uma notícia triste para todos os cidadãos e pessoas que amam a paz em todo o mundo. A notícia é que Martin Luther King foi baleado e morreu esta noite em Memphis, Tennessee.

Uma longa sequência com cenas de arquivo de imagens de reais de RFK ganha destaque na montagem. A partir de então, a obra segue para a ficção, procurando manter as informações que ajudam a manter o efeito de realidade esperado: como o crédito da data e local dos fatos - Los Angeles, 4 de junho de 1968 - Hotel Ambassador, sede da campanha de Kennedy - e a inserção de imagens de arquivo que mostram RFK em campanha política. Tais imagens são misturadas sutilmente à trama ficcional através dos aparelhos de televisão que estão ligados e algumas cenas nas quais os personagens ficcionais estão em suas atividades rotineiras no trabalho ou no quarto do hotel. Tal procedimento narrativo sugere exatamente o que buscamos defender nesta investigação: que, num docudrama, a mistura entre ficção e realidade deve ser evidenciada em toda a narrativa. 
Na sequência final e ao som de Sound of Silence, imagens de arquivo e encenações são misturadas e todos os personagens da ficção se encontram em um evento comemorativo no qual RFK agradece à população os votos que obteve. Ouvem-se disparos de armas. A encenação dá conta de uma dramatização que representa o desespero das pessoas diante do ocorrido. Mais uma vez, cenas da ficção são intercaladas com imagens reais de RFK baleado. Esse recurso de misturar encenação com imagens de arquivo como se os atores estivessem naquele tempo e espaço é uma das marcas registradas do gênero.

No final, os créditos cumprem a função de informar ao espectador o desfecho da história com o seguinte texto: Robert Francis Kennedy morreu no hospital Bom Samaritano na manhã de 6 de junho de 1968. Sua esposa, Ethel, estava ao lado dele. As outras vítimas do atentado daquela noite sobreviveram. Fotografias em preto e branco dão conta da trajetória familiar e política de RFK: sua infância, casamento e sua carreira de senador.

Nixon (1995), dirigido por Oliver Stone, é baseado na história real de Richard Nixon, ex-presidente dos Estados Unidos, que renuncia após ter seu nome envolvido no Watergate, escândalo político ocorrido na década de 1970. A trama enfoca sua infância, sua carreira política e a derrota para John F. Kennedy nas eleições presidenciais de 1960. Como nos exemplos anteriores, Nixon, em seus créditos iniciais, apresenta instrução para que seja lido como uma obra baseada em fatos reais: Este filme é uma interpretação dramática com base em informações públicas e um registro histórico incompleto. Alguns acontecimentos foram compostos, conjeturados ou resumidos. "O que lucra um homem, ganhando um mundo inteiro e perdendo a própria alma?" Mateus 16:26. Deve-se destacar a montagem híbrida de uma cena na qual há uma combinação de imagens reais de John Kennedy com imagens da ficção de Robert Nixon, interpretado por Anthony Hopkins. São imagens de arquivo em preto e branco do debate entre os candidatos à presidência dos Estados Unidos. Evidentemente, essa montagem híbrida tem por finalidade inserir o personagem da ficção dentro do referente real: é como se, de fato, ele estivesse ali naquele tempo e naquele espaço. Com efeito, é possível indicar o recurso da montagem híbrida como forma de provocar a leitura docudramentarizante. Chama a atenção a intensa dramatização acerca da reconstituição da história do ex-presidente norte-americano: sua infância pobre, as dificuldades de relacionamento com o pai , a superação da morte de seus dois irmãos (Harold e Arthur) vitimados pela tuberculose e a superproteção de sua mãe, conforme ilustraremos com parte de um diálogo de uma cena na qual Nixon e sua mãe choram pela morte precoce de um dos 
irmãos. Nixon titubeia se aceita o dinheiro deixado por seu irmão para que possa custear o curso de direito:

Mãe: - Richard...

Nixon: - Eu não posso.

Mãe: - Mas você precisa. A escola de direito é um presente do seu irmão.

Nixon: - Ele teve de morrer para isso?

Mãe: - Algo deve brotar de tudo isto. É para nos fortalecer. Você é mais forte que Harold e que Arthur. Deus escolheu você para sobreviver.

Nixon: - E quanto à felicidade, mãe?

Mãe: - Você encontrará a paz interior Richard. Força nesta vida. Felicidade na próxima.

Salientamos que muitos filmes ou programas, como os anteriormente citados, são geralmente classificados como dramas, dramas biográficos, comédias dramáticas (Drama comedy) ou jornalismo investigativo (Linha Direta). Raramente encontramos uma obra que se assume explicitamente como docudrama. Disso resulta a hipótese de que os mecanismos de funcionamento ou das fronteiras que regem as características do docudrama são pouco conhecidos ou explorados. O fato de suas fronteiras não serem claramente compreendidas não significa que elas não existam. Pelo contrário, muitas obras, como procuramos demonstrar, podem perfeitamente serem lidas como docudramas ou, em outros termos, permitem acionar a leitura docudramentarizante. Pelo exposto, esperamos que as reflexões aqui propostas sirvam de base para melhor compreender o gênero e que os realizadores, produtores e críticos passem a adotar o docudrama como termo que melhor traduz uma obra audiovisual baseada em fatos reais e que manifestam uma estrutura narrativa semelhante aos faits divers (relações de causalidade, coincidência e imanência), conforme exploramos anteriormente. No próximo capítulo, aplicaremos a proposta de leitura docudramentarizante nas telenovelas brasileiras na tentativa de melhor compreender a tendências que as telenovelas contemporâneas (novelas híbridas) manifestam quando misturam elementos da ficção com a realidade. 


\section{Capítulo 3}

\section{Docudrama na telenovela: qualquer semelhança com fatos e pessoas reais é mera coincidência?}

Falar em telenovela é necessariamente falar no Brasil como um dos maiores produtores e exportadores do formato no mundo. Além do Brasil, destacam-se México, Venezuela, Colômbia, Argentina e Chile que, cada vez mais, especializam-se na produção e aperfeiçoam as técnicas dessa forma de produção de ficção seriada. No IV Seminário Internacional Obitel - Mercados Globais, Histórias nacionais ${ }^{74}$, realizado no Rio de Janeiro em 2008, pesquisadores e representantes de cada um desses países apresentaram resultados de pesquisas sobre ficção seriada e, em especial, a telenovela. Cada país exibiu uma montagem com as dez maiores audiências (a maioria telenovela). Naquele momento, demonstrou-se o evidente: cada país possui técnicas e estéticas próprias de produção do formato, umas mais imaginativas (melodramáticas), outras menos, mas com algo em comum: em todos os países a telenovela busca refletir aspectos da cultura, problemas políticos, econômicos e sociais. Disso resulta a possibilidade de se pensar a telenovela como o principal produto de ficção seriada da América Latina e de que ela já faz parte da cultura de cada uma dessas nações. Notou-se que cada país, a sua maneira, demonstra a preocupação em reconhecer a importância da telenovela enquanto narrativa e que, mesmo dentro de esquema estrutural de repetição, busca inovar e levar a "realidade" de cada país para dentro da ficção.

Este capítulo pretende refletir sobre a combinação entre a ficção e a não-ficção na telenovela brasileira, isso porque é recurso comum dos autores brasileiros, a exemplo de Manoel Carlos e Glória Perez, abrirem espaço para pessoas "reais" darem seus depoimentos de vida dentro da trama ou de citarem fotos sociais e históricos em suas tramas. Tal constatação implica formular uma questão nos seguintes termos: é admissível afrmar que a telenovela brasileira, nesse sentido, se constitui como uma meta-categoria do docudrama? Em que medida?

74 Realizado no Hotel Pestana em Copacabana, Rio de Janeiro nos dias 23, 24 e 25 de junho de 2008, e promovido pelo Centro de Estudos de Telenovela da USP e Globo Universidade. Na ocasião, pesquisadores do Obitel dos países que compõem a rede de pesquisa,autores e colaboradores da TV Globo debateram os caminhos da ficção seriada de televisão. O seminário contou com a presença de Jesus Martin-Barbero, que ministrou a conferência inaugural: Viajes de telenovela y aventuras de su investigación - un relato de experiencias compartidas latinoamericanamente. 
As possíveis respostas para essa problematização visam contemplar discussões entre a relação da telenovela com o docudrama ou das relações entre a ficção e a "realidade" na telenovela brasileira. Reflexões teóricas sobre a relação entre ficção e realidade não representam novidade nas pesquisas acadêmicas, sobretudo, no cinema, área na qual há um vasto estudo a respeito do documentário, cinema verdade e atualidades reconstituídas. De outra parte, observamos uma também respeitável produção acadêmica sobre o tema na televisão, principalmente na obra "Ficção e realidade: a construção do cotidiano na telenovela", escrita pela profa. Dra. Maria de Lourdes Motter (2003) e, também, os projetos "Ficção e realidade: a telenovela no Brasil; o Brasil na telenovela", coordenado pela Profa. Dra. Maria Aparecida Baccega, e "A construção do cotidiano na telenovela", coordenado pelas Profas. Dras. Maria Lourdes Motter e Maria Immacolata Vassallo de Lopes. Fato é que, para tentar elucidar o problema levantado no início dessa escrita, ou seja, como classificar ou compreender a aparição de pessoas "reais" ou naturais nas tramas de telenovela, é inevitável recorrer ao campo cinematográfico como forma de referência para iniciarmos nossa discussão. Por exemplo, o termo cinema verdade já suscitava e admitia a intervenção do "real" na obra cinematográfica. Nessa perspectiva, Chronique d'un Été (Crônica de um Verão), filme dirigido por Jean Rouch em parceria com Edgar Morin, apresentou uma nova forma interativa do documentário segundo Da-rin (1995). Assumindo a recente técnica do som direto, essa obra enfatizava a palavra através de diálogos e entrevistas entre realizadores e "atores sociais". Com esse filme, Rouch e Morin "recolocaram circulação o termo cinemaverdade, que logo transformou-se na designação global dos movimentos que empregavam os novos métodos de filmagem com equipamentos portáteis" (Da-rin, 1995, p. 115). Vale lembrar que alguns pesquisadores entendem Cinema Direto e Cinema Verdade como sinônimos, já outros autores preferem a utilização do termo Cinema Direto para as realizações com pouca intervenção dos realizadores e Cinema Verdade, quando o diretor interage com o fato:

O documentarista do cinema direto levava sua câmera para uma situação de tensão e torcia por uma crise; a versão de Rouch do cinema verdade tentava precipitar uma. $\mathrm{O}$ artista do cinema direto aspirava à invisibilidade; o artista do cinema verdade de Rouch era frequentemente um participante assumido. $\mathrm{O}$ artista do cinema direto desempenhava o papel de um observador neutro; o artista do cinema verdade assumia o de provocador. (Ruspoli apud Da-rin 1995, p. 115) 
Tecnicamente, ao contrário do cinema, a televisão já nasceu direta. Dada a impossibilidade de gravação de sons e imagens na década de 1950, a programação de televisão era transmitida ao vivo, ou seja, sons e imagens eram simultâneos e transmitidos no mesmo momento da captação.

A técnica do cinema direto só foi possível com o desenvolvimento de equipamentos de captação audiovisual na década de 1960 que possibilitaram jornalistas estadunidenses a agilizarem seus trabalhos de reportagens. Segundo Da-rin (1995, p. 114), o representante a ser destacado na técnica do cinema direto, conforme já apontamos, é Jean Rouch, com seu filme Chronique dún Été (Crônica de um Verão) em 1960, realizado em conjunto com Edgar Morin. Destaca-se a voz off do início do referido filme: "este filme não foi representado por atores, mas vivido pelos homens e mulheres que dedicaram momentos de suas vidas a uma experiência nova de cinema verdade" (Rouch e Morin apud Da-Rin (1995 p. 115).

Com o filme Jaguar (1954/1967), Rouch iniciou seu interesse pela ficção como ferramenta de compreensão da realidade: “todo o filme é pura ficção, nenhum desses personagens nunca foi na vida o que ele é na história: é ficção, mas ficção em que as pessoas desempenham seus próprios papéis numa situação dada (...)” (Rouch apud Da-Rin, 1995, p. 123). Para esse tipo de filmagem, Rouch não utilizava roteiros pré-estabelecidos, procedimento básico para qualquer filme de ficção, o que havia eram esboços das situações. "Eu introduzia as pessoas em uma situação, a câmera era o pretexto, e o resto corria solto, acontecia um pouco qualquer coisa...” (Rouch apud Da-Rin, 2004, p. 124).

De maneira análoga, Glória Perez, em O Clone (Globo, 2001) colocou pessoas "reais" (cantores, atores, atrizes) vivendo seus próprios papéis e contracenando com personagens da ficção da novela. As cenas do bar da personagem Jurema, interpretada por Solange Couto, traziam diversas personalidades do campo da música, futebol e televisão:

Na verdade, na hora do bar da Jura, eu dava indicações de por onde a cena devia ir. Por exemplo, a frase com que a Jura recebia a pessoa dava a indicação mais ou menos pra onde eles deviam ir. Por exemplo, vai o Benito (de Paula) lá e aí, quando sai, o outro disco 'que saudade de você'. Relembrem as músicas dele, coisas assim. Mas você tem que dar uma abertura, um espaço de improviso ali que depois na edição se resolve. Mas tem que dar um espaço de improviso porque você não pode escrever pro convidado ${ }^{75}$.

\footnotetext{
${ }^{75}$ PEREZ, Glória. Entrevista concedida ao autor. Curitiba. 30 junho, 2003, grifo nosso
} 
Avançamos na hipótese de que, cada vez mais, a "realidade" tem fornecido, de maneira mais explícita, as temáticas exploradas pelas telenovelas, formato que constantemente buscar inovar, se hibridiza e rompe com dicotomias clássicas severamente trabalhadas pelo folhetim do século XIX. Por outras palavras, a telenovela tem retratado fatos do cotidiano, notícias de grande repercussão, comoção nacional etc, e acaba por cumprir uma função além do entretenimento: o de informar e educar. Nessa perspectiva, o espectador (de massa), muitas vezes não habituado a se informar através dos jornais e revistas que apresentam a notícia um pouco mais contextualizada que a televisão, consegue tirar suas próprias conclusões mais pelas encenações da ficção do que propriamente por uma notícia no telejornal que dura poucos segundos no ar. De certo modo, a sociedade pauta a telenovela. Entretanto, também é inegável que a telenovela pauta a sociedade. Estudos feitos por teóricos da comunicação apontam uma hipótese chamada de agenda-setting que ilustra bem essa questão. Segundo essa hipótese, a mídia, de uma maneira geral, exerce um poder de agendar temas que devam chamar a atenção da sociedade. Ela agenda sobre o que falar - aborto, síndrome de down, tetraplegia, drogas, entre outros - mas não necessariamente sobre o "como falar". Nesse sentido, o espectador é convidado a refletir sobre determinadas questões pontuais. Disso resulta a preocupação central dessa investigação, que busca compreender esta tendência contemporânea de a "realidade" se fazer mais presente em uma obra tradicionalmente ficcional, fazendo com que a telenovela se aproxime de outros gêneros como o docudrama e rompa com dicotomias clássicas perpetuadas pelo folhetim como procuraremos demonstrar a seguir.

\subsection{Desconstrução do modelo tradicional da telenovela}

Como vimos no primeiro capítulo da presente investigação, a história da telenovela brasileira pode ser dividida em quatro periodizações: novelas sentimentais, novelas "realistas", novelas naturalistas e novelas híbridas e, na transição de um período para o outro, a telenovela brasileira "inovou", se modernizou e "os personagens se libertam, em alguma medida, do peso do destino e, afastando-se dos grandes símbolos, se aproximam das rotinas cotidianas e das ambiguidades da história, da diversidade das falas e dos costumes" (Martin-Barbero, 1999, p. 121).

Enquanto alguns países produtores de telenovela, como o México, ainda produzem 
narrativas semelhantes às novelas sentimentais, onde imperam dicotomias rígidas como o bem vs mal, o Brasil busca renovar a produção das narrativas ficcionais, rompendo com tradicionais oposições. Veja o que Glória Perez afirma quando compara as novelas mexicanas com as brasileiras:

Acho que a novela mexicana tem uma diferença muito essencial da nossa. Elas são novelas essencialmente de trama, elas não têm o menor aprofundamento psicológico, não há a menor preocupação de nuances psicológicas nas personagens. São novelas de trama, só acontece a trama, a parte psicológica não é explorada. Então, se só acontece a trama, as coisas são muito rígidas: essa personagem é boa, essa personagem é má e ela será assim até o fim, porque não há preocupação nesse sentido. Já na novela brasileira, a gente equilibra ou procura equilibrar a trama com um desenho psicológico das personagens. Na novela mexicana, tem uma coisa muito interessante. Até o Wolf, quando foi dirigir o Vale Tudo, quase morreu de desgaste porque eles trabalham com ponto, pra você ver como o psicológico é pouco importante. Eles não decoram o papel, eles trabalham com ponto, é dificílimo. O psicológico não tem a menor importância, o que tem importância é a trama ${ }^{76}$.

Em outros termos, Glória Perez afirma que as novelas mexicanas, ao contrário das brasileiras, ainda segue um modelo clássico do folhetim que prevê um certo grau de maniqueísmo. $\mathrm{Na}$ narrativa tradicional folhetinesca, tornaram-se clássicas dicotomias inerentes ao gênero: a luta do bem contra o mal, as diferenças sociais entre ricos e pobres, o feio e o belo, entre outros, além de outras questões contraditórias como as diferenças étnicas entre o branco e o negro ou índios, como no caso de países de tradição indígena como o México.

Podemos afirmar que a telenovela brasileira passou a incorporar em suas narrativas mais aspectos da "realidade" e acabou por desconstruir a rigidez do folhetim clássico que imperou durante as novelas sentimentais das décadas de 1950 e 1960. Embora a desconstrução ${ }^{77}$ não constitua propriamente um método ou uma técnica de análise, as questões por ela debatidas apresentam-se particularmente interessantes para problematizarmos as mudanças pelas quais a telenovela brasileira passou e as constantes transformações em

\footnotetext{
${ }^{76}$ PEREZ, Glória. Entrevista concedida ao autor. Curitiba. 30 junho, 2003.

77 A desconstrução, termo cunhado pelo filósofo Francês Jacques Derrida, é uma postura filosófica pósestruturalista cujas características centrais apoiam-se na "atomização dos objetos e dos pontos de vista, em oposição ao projeto totalizador do estruturalismo; rejeição da razão como universal ou fundacional; o descentramento do sujeito; o interesse pelas diferenças, exclusões e margens; o interesse pela história e pela cultura como constructos discursivos; a dissolução das fronteiras entre as disciplinas ". (Perrone-Moisés, 2003, p. 218)
} 
curso:

\begin{abstract}
A enorme tarefa proposta por Derrida, desde seus primeiros livros, é a desconstrução da metafísica ocidental, remanescência do platonismo, com seus conceitos de origem, de finalidade, de representação. Para fazer essa crítica, Derrida se propôs a desfazer dualismos que constituem o idealismo, e criou a noção de diferência (différance), a partir do jogo de palavras que o Francês permite (différenceldifférance). A diferência remete tanto às diferenças (semânticas, genéricas, históricas, étnicas, culturais etc.) como ao adiamento do sentido final, da verdade estabelecida uma vez por todas. (Moisés, 2003, p.222)
\end{abstract}

Um certo descontentamento com a cultura (ciência, arte burguesa, entretenimento etc) leva diretamente à análise da desconstrução, nos moldes propostos por Derrida. A análise desconstrutivista teve origem num tipo de filosofia igualmente niilista: a fenomenologia, bem como nas ideias de outros autores sapienciais como Nietzsche. Faremos abordagem de um percurso (possível) traçado até o pensamento da desconstrução dos signos da cultura.

As oposições platônicas entre mundo das formas e mundo das ideias, corpo vs alma, e também a oposição cartesiana entre mente e corpo, entre outras, são duramente combatidas por filósofos da modernidade, tais como Nietzsche (século XIX) e Edmund Husserl (século $\mathrm{XX)}$. Uma das principais correntes filosóficas a argumentar pelo equívoco do pensamento obtido através de oposições (dualismos) foi a fenomenologia, nos moldes expostos especialmente por Husserl. Analisando a crise das ciências europeias, Husserl critica a redução positivista das ciências à mera ciência de fatos, como aqueles obtíveis, muitas vezes, através de dualismos que já são intencionalmente postos por quem pensa determinado objeto científico e cujo trabalho, a partir de então, será justificar tal pensamento no mundo da vida. A própria dualidade entre mundo objetivo e mundo subjetivo é posta em xeque, uma vez que a razão obtém seus processos através de intencionalidades já antepostas pelo pesquisador à análise do objeto estudado e que será verificado e tornado verdadeiro cientificamente. Nada parece autorizar-nos a pensar o ser, suas emoções, seus conflitos, a partir de (simples) dualidades, embora seja comum que o façamos.

Todas as questões que envolvem as ciências objetivas, matematizadas, com fins de obtenção de verdades etc, tendem a conduzir à massificação, uma vez que a inteligência (razão) humana permanece dirigida ao exame, cálculo e avaliação de objetos, desconsiderando os fatores subjetivos que acabam por conferir sentido aos fenômenos tidos como objetos verificados. Para a fenomenologia (estudo daquilo que se mostra), não há como 
separar a mente da realidade por ela percebida, o que também indica um engano do pensamento iluminista e da razão emancipatória e progressista.

Os filósofos da Escola de Frankfurt chamariam de razão instrumental ou razão técnica essa forma de racionalidade que se pretende científica e que está no centro do pensamento logocêntrico da modernidade. Destacamos a expressão de Husserl "crise das ciências" (europeias), relativa ao erro das ciências modernas que pretendem a obtenção de verdades objetivas, uma vez que o que aparece em cada pesquisa é o enigma da subjetividade, da forma de lançar-se rumo ao objeto da reflexão. Conforme Husserl:

Queremos precisamente iniciar El cambio antes indicado de toda La dirección de nuestras reflexiones. Al efectuarlo pronto descubriremos que a problematicidad que padece La psicologia, no solo em nuestros dias sino ya desde siglos - uma "crisis" genuinamente suya-, le corresponde uma significación central em La manifestación de enigmáticas e insolubles obscuridades de las ciências modernas, incluso em La matemática; y em conexión com ello, em La aparición de um tipo de enigma Del mundo que fue desconecido em los tiempos anteriores. (Husserl, 1984, p.10)

Martin Heidegger (século XX) também faria crítica vigorosa à ciência moderna: neutra, mas criadora de uma metafísica do tipo positivista e progressista. Conforme Heidegger:

\begin{abstract}
A essência do que hoje se denomina ciência é a investigação. Em que consiste a essência da investigação? Consiste em que o conhecer se instala a si mesmo como um proceder (grifo nosso) num âmbito do ente, da natureza ou da História. Proceder não significa aqui apenas o método, o procedimento (...) O projeto traça previamente (grifo nosso) a maneira pela qual o proceder conhecedor deve ligar-se ao setor aberto. Essa ligação é o rigor da investigação. Pelo projeto do esboço e da determinação do rigor o proceder assegura para si o seu setor de objetos em meio ao âmbito do ser. (Heidegger, 2005, p. 194)
\end{abstract}

A exatidão de conceitos como bem, mal etc, bem como a ideia de progresso através da ciência e do uso científico da razão, passa a ser questionada por estes e por outros filósofos que são antecedentes de Jacques Derrida e a análise por ele desenvolvida da desconstrução, forma de pensamento sobre o pensamento de difícil categorização, mas que possibilita perspectiva bastante útil de análise da cultura ao refletir acerca de algo que possa estar sobredeterminado (ou oculto) pelo pensamento.

Na obra A escritura e a diferença, Derrida analisa o empreendimento do teatro de Antonin Artaud (teatro da crueldade), no capítulo chamado A palavra soprada, com menções 
a Heidegger, Nietzsche, entre outros. Ele chama atenção para a parte enigmática de qualquer obra textual, eis que esta possui um sentido que escapa a qualquer abordagem unívoca, seja psicológica ou médica (duas ciências com procedimentos próprios de investigação), mesmo quando se dirige a uma abordagem da "enfermidade" loucura. Conforme Derrida:

(...) aquilo de que Artaud é apenas testemunha é uma essência universal do pensamento. A aventura total de Artaud seria apenas o índex de uma estrutura transcendental (grifo nosso): "pois Artaud jamais aceitará o escândalo de um pensamento separado da vida, mesmo entregando-se à experiência mais direta e mais selvagem jamais feita da essência do pensamento entendido como separação, dessa impossibilidade que afirma contra si própria como o limite de seu infinito poder”. (Derrida, 1995, p. 110)

Manifestando-se cúmplice da metafísica de Artaud, metafísica que manifesta diferença, duplicidade, destruição, presença e ausência das coisas suscitadas ao pensamento através da obra, afirma Derrida:

(...) Através dela (metafísica da arte de Artaud, grifo nosso) diz-se a inserção necessária de todos os discursos destruidores, que devem habitar as estruturas por eles derrubadas e nelas abrigar um desejo indestrutível de presença plena, de não-diferença: ao mesmo tempo vida e morte. (Derrida, 1998, p. 147)

Derrida, quanto ao estudo da linguagem e da arte da escrita, pode ser considerado um pós-estruturalista, no sentido de rejeitar pretensões científicas apoiadas em diagramas lineares (há a perspectiva, por exemplo, da análise transversal dos elementos do texto), entre outros moldes de repetido uso da análise da linguagem e das obras literárias. Conforme Culler, "Derrida, nas palavras de Lentricchia, trouxe não estruturalismo, mas pós-estruturalismo" (1997, p. 27).

A desconstrução pretende uma estratégia de interpretação da linguagem, dos termos por ela utilizados, numa forma de análise entre a filosofia e a literatura, colocando sob suspeita tanto o que é revelado quanto o que está oculto no signo e, posteriormente, na análise da significação. Não se trata apenas da análise de uma oposição, mas de pôr em destaque tanto a entidade positiva (presença; relação com o sensível; presença à consciência) quanto aquilo que está ausente no signo, mas que permanece inteligível. Desse modo, através da linguagem, o que se pode obter não será o verdadeiro em relação à ideia a ser transmitida, mas um vestígio de um vestígio obtido pela observação de diferenças. Conforme Culler, “a natureza arbitrária do signo e o sistema sem nenhum termo positivo dão-nos a paradoxal 
noção de um "vestígio instituído", uma estrutura de referência infinita em que há apenas vestígios - vestígios anteriores a qualquer entidade da qual poderia ser o vestígio" (1997, p. 115).

Há algo que se esconde e que se mostra sob o signo. Há camadas de significação, parece dizer-nos Derrida. O processo de elaboração de um discurso sobre um objeto evidencia um jogo daquilo que se pretende representar. Tentar compreender um signo apenas a partir de oposições é desprezar a intuição sempre presente daquilo que permanece excluído dentro do texto, uma vez que qualquer texto apresenta múltiplos sentidos. No ato da escrita ou da leitura de um texto há, além da intencionalidade sobre aquilo que foi escrito, componentes como a imaginação criadora (do leitor), a liberdade poética (do escritor) e contextualizações várias que interferem na apreensão de apenas um significado verdadeiro da ideia que se pretendeu representar através do texto. O sentido do texto permanece como ato inaugural do sentido. Conforme Derrida, “o sentido deve esperar ser dito ou escrito para se habitar a si próprio e tornar-se naquilo que a diferir de si é: o sentido. É o que Husserl nos ensina em A origem da geometria. O ato literário reencontra assim na sua origem o seu verdadeiro poder" (1995, p. 24). Um jogo cujas regras não são totalmente conhecidas por aquele que pretende desafiá-lo. Conforme Culler:

O que a desconstrução propõe não é um fim às distinções, não uma indeterminação que faz do sentido a invenção do leitor. O jogo do sentido é resultado do que Derrida chama de "o jogo do mundo", no qual o texto geral sempre fornece outras conexões, correlações e contextos. (Culler, 1997, p. 154)

No tradicional folhetim, parece haver o hábito de descrever os conflitos emocionais do ser através de oposições. O que se quer dizer é que temos como hábito, nessa tradição textual, associar ideias numa relação de contiguidade ou de causalidade e efeito. Temos a noção do claro porque há uma conexão lógica e posta com seu contrário, o escuro mediado pela ideia de claridade; assim como sabemos o que é doce porque temos a noção do amargo quando a ideia é mediada pela noção de sabor.

Conforme afirma Ferrara:

A associação por contiguidade corresponde a um raciocínio de tipo elementar e se refere a ideias que se associam por serem sugeridas pela experiência cotidiana, numa relação metonímica em que a apreensão de uma parte do sistema traz à memória todo o conjunto do mesmo sistema. A 
associação por similaridade, ao contrário, supõe um raciocínio mais elaborado e consciente a partir da natureza de duas ideias que se aproximam por força de alguma semelhança ou analogia. (Ferrara, 1999, p. 72)

Falar em oposição de ideias é falar, em termos de uma semiótica discursiva, do nível fundamental do texto. O percurso gerativo de sentido, tal como proposto por Greimas, é estruturado em três níveis interdependentes chamados de fundamental, narrativo e discursivo $^{78}$. No nível narrativo operam-se transformações ocasionadas pelos sujeitos, ocorrem ações capazes de levar a história adiante, é a história em si; no nível discursivo, no qual o sujeito da enunciação cria mecanismos discursivos para criar efeitos de realidade, ancora-se o texto no tempo, espaço e pessoas; e o fundamental, no qual as ideias são organizadas em oposições. Dos três níveis, o que mais se aproxima de nosso principal ponto de reflexão é o nível fundamental, uma que vez que ele é caracterizado por oposições semânticas mínimas e nos ajuda a tentar compreender os mecanismos de funcionamento e a formação de hierarquias entre as oposições. Por outras palavras, em qualquer produção de discurso, é possível apontar, através do texto, ideias que se chocam porque são contrárias ou contraditórias. Nesse sentido, Fiorin afirma que:

Os termos opostos de uma categoria semântica mantêm entre si uma relação de contrariedade. São contrários os termos que estão em relação de pressuposição recíproca. O termo /masculinidade/ pressupõe o termo /feminilidade/ para ganhar sentido e vice-versa. Se se aplicar uma operação de negação a cada um dos contrários, obtêm-se dois contraditórios: /não masculinidade/ é o contraditório de /masculinidade/ e/ não feminilidade/ é o de/ feminilidade. Cada um dos contraditórios implica o termo contrário daquele que é o contraditório. Assim, /não masculinidade/ implica /feminilidade/ e/ não feminilidade/ implica/ masculinidade. (Fiorin, 2009, p.22).

Se tomarmos como exemplo a oposição clássica da telenovela representada pela luta do bem contra o mal em um quadrado semiótico, teremos o seguinte:

78 Ver: FIORIN, José Luiz. Elementos de análise do discurso. São Paulo: Contexto, 2009, p. 17-53. 


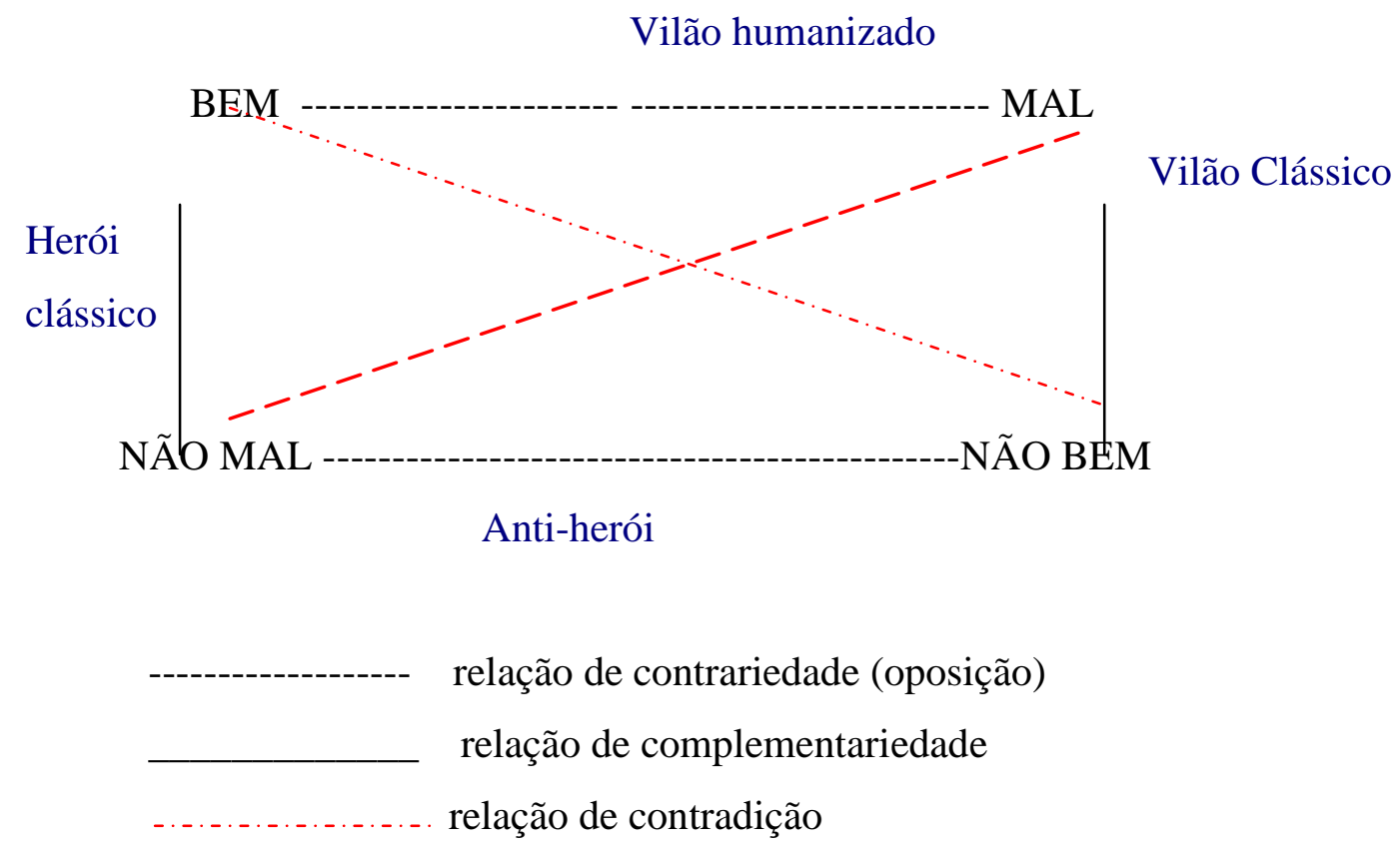

O herói clássico pode ser definido como aquele que é do bem e não do mal (numa tradicional história folhetinesca equivale ao "mocinho": aquele que é incapaz de cometer qualquer maldade); o vilão clássico é o personagem que é mal e não é do bem (um vilão típico de novela mexicana que é incapaz de demonstrar sentimentos nobres como a Flora (Patrícia Pillar), em A Favorita (Globo, 2008)). O anti-herói é conhecido como aquele que não é do mal e também não é do bem (é o herói sem caráter, como Macunaíma de Mário de Andrade, seria uma espécie de "herói" mais humanizado) e o vilão humanizado é aquele que é do bem e do mal (equivale a um personagem ambíguo, como a Nazaré (Renata Sorrah) em Senhora do Destino). Herói e vilão são opostos, ao passo que o vilão humanizado e o antiherói são contradições. O quadrado semiótico "é um antigo dispositivo lógico que remonta a Aristóteles, e que foi usado na semiótica contemporânea sobretudo pela escola de Greimas. Serve para determinar e desdobrar um conceito em relação aos conceitos que lhe são opostos", define Volli (2007, p. 72).

Tradicionalmente, cada parte da oposição pode ser valorizada culturalmente de maneira positiva (valores eufóricos) ou negativa (valores disfóricos). Como é óbvio, os tradicionais "mocinhos" de uma narrativa são considerados positivos (eufóricos) em relação ao vilão (disfóricos). Numa desconstrução, esse esquema é rompido, essa prioridade ou hierarquia de um termo em relação ao outro é invertida. Em síntese: "desconstruir uma oposição é desfazê-la e deslocá-la, situá-la de modo diferente”, afirma Culler (1997, p. 172). Desse modo: 
Em uma tradicional oposição filosófica, não temos uma pacífica coexistência de termos contrapostos, mas uma violenta hierarquia. Um dos termos domina o outro (axiologicamente, logicamente, etc), ocupa a oposição de comando. Desconstruir a oposição é, acima de tudo, reverter a hierarquia em determinado momento. (Derrida apud Culler, 1997, p. 99).

Nos dias correntes, a telenovela brasileira é conhecida e reconhecida como um programa de televisão eminentemente ficcional, mas que soube, através de sua história, representar a cultura e o modo de ser de toda uma nação, desenvolvendo tramas mais complexas e ambíguas, sempre em sintonia com as questões de seu tempo. Sua importância para o Brasil é de tal sorte que é impossível falar em cultura brasileira sem fazer referência à telenovela. Desde as novelas realistas, que tiveram início no final da década de 1960, iniciouse um processo de transformação de desconstrução de narrativas tradicionais herdadas do folhetim clássico:

\begin{abstract}
Nas primeiras telenovelas diárias, os dramas mostram príncipes europeus do fim do século passado, aristocratas mexicanos, milionários que empobrecem, mas que, em compensação, obtêm a felicidade, que decorre das coisas simples, crianças desamparadas (na verdade, herdeiras de fortunas incalculáveis) e justiceiros mascarados. A função da trama é colocar, ao seu final, as coisas nos seus devidos eixos, no lugar em que se encontravam antes de os primeiros capítulos irem ao ar. (...) A cada final de capítulo resta ao proprietário de um aparelho receptor ficar na expectativa do que irá acontecer em seguida, quando o herói com certeza enfrentará novas armadilhas que se interpõem entre ele e a justiça definitiva. Igualzinho ao seriado cinematográfico, a mesma estrutura do folhetim de Eugène Sue ou da novela radiofônica. Sem novidades. (Fernandes, 1994, p. 60)
\end{abstract}

Como vimos, a novela Beto Rockfeller (Tupi, 1969), de Bráulio Pedroso, rompeu paradigmas, inaugurou no formato a tendência de as narrativas serem mais "realistas", terem falas mais coloquiais e comportamentos dos personagens condizentes com o cotidiano do brasileiro. Pela primeira vez um anti-herói ${ }^{79}$ foi personificado na condição de protagonista, rompendo com a estrutura maniqueísta vigente, apresentando personagens mais complexos e contraditórios. O anti-herói é um personagem necessariamente ambíguo, não é bom, nem mal; pode ser definido como um herói sem caráter, ou um malandro capaz de trapacear para se dar bem:

79 Segundo Moisés (2004, p. 28) a expressão “anti-herói” entrou em uso graças a Dostoievski, que a empregou em Memórias do subsolo (1864) e designa um personagem que apresenta características opostas às do herói que é progressivamente desmistificado e humanizado. Em outras palavras, é um personagem que não deve ser seguido nem servir de exemplo de boas maneiras e bons costumes. É um "herói sem nenhum caráter", como Macunaíma (1928) de Mario de Andrade. 
Beto (Luis Gustavo) é um charmoso representante da classe média que trabalha numa casa de calçados. Com sua intuição e perspicácia, consegue penetrar na alta sociedade, através de sua namorada Lu (Débora Duarte), sempre passando por milionário. Quem Beto preferirá afinal? Lu, a garota sofisticada e rodeada de gente importante, ou Cida (Ana Rosa), a humilde namoradinha do bairro onde mora? A contradição será explicada através do seu nome: Beto, humilde trabalhador, da rua Teodoro Sampaio, Rockfeller, sofisticado e badalado, da rua Augusta. Enquanto vacila entre os dois extremos, a grã-finagem dobra ante seu maniqueísmo, e ele tem que fazer toda a ordem de trapaça para que sua origem - que já não é segredo para Renata (Bete Mendes), uma jovem grã-fina decadente - não seja descoberta. (Fernandes, 1994, p. 116).

É justamente a ambiguidade e a contradição que marcam a figura do anti-herói. Na verdade, Beto Rockfeller era um mentiroso disposto a tudo para fazer parte da elite financeira paulistana. Tal construção de personagem representou um certo grau de novidade no formato: antes nenhum protagonista de telenovela poderia ser "malandro" disposto a tudo para subir na vida. $\mathrm{O}$ que equivale a dizer que os personagens tornaram-se mais humanos, ou seja, mais próximos de uma pessoa "de verdade". Em outros termos, houve uma rompimento da clássica dicotomia bem vs mal com a consequente desconstrução de um esquema narrativo tradicional. Na história da telenovela brasileira, ficaram famosos os casos de protagonistas anti-heróicos, como o personagem Carlão (Francisco Cuoco) de Pecado Capital (Globo, 1975), "que ascende socialmente após se empossar ilegalmente do dinheiro de um assalto a banco" (Fernandes, 1994, p. 194), o personagem Sinhozinho Malta (Lima Duarte), em Roque Santeiro (Globo, 1985), um rígido coronel que comanda uma tropa de jagunços ao mesmo tempo que se entrega à paixão que nutre pela viúva Porcina (Regina Duarte). Algumas cenas tornaram-se antológicas como a que Sinhozinho Malta finge ser um cãozinho pedindo perdão a sua amada Porcina. Outros exemplos de protagonistas anti-heroínas podem ser ilustradas com Tieta (Globo, 1989), baseada na obra de Jorge Amado. Tieta é uma jovem que foi escorraçada de sua cidade natal. Após 25 anos, ela retorna ao agreste rica e disposta a se vingar de todos que lhe fizeram mal, além de se envolver emocionalmente com um sobrinho seminarista. Em Anjo Mau (Globo, 1976), "Nice (Suzana Vieira) é a moça pobre que não mede esforços para conseguir seus objetivos. Emprega-se como babá e passa a cortejar o milionário Rodrigo (José Wilker), fazendo intrigas com Léa, sua rival, e Stela, sua patroa”. (Fernandes, 1994, p. 195).

É interessante notar que não só os "mocinhos" e mocinhas" das tramas se 
humanizaram; os vilões contemporâneos também se transformaram, tornaram-se mais ambíguos. Ao contrário dos vilões clássicos, os da contemporaneidade são contraditórios: ao mesmo tempo que são capazes de cometer as mais diversas atrocidades, podem manifestar sentimentos nobres por algum outro personagem ou situação. Talvez resida aí, na desconstrução da dicotomia clássica entre o bem e o mal, a explicação para o sucesso cada vez mais arrebatador que os vilões de novela têm feito entre os telespectadores. "Cada vez mais os grandes vilões das novelas estão sendo cultuados pelo público. Se em outros tempos o final do antagonista só podia ser a morte ou a prisão, hoje o público brasileiro vibra quando um personagem, que tratou de estragar a vida de todos na novela, acaba escapando impune", afirmam Navarro \& Martins (2009, p. 03) ${ }^{80}$. Em Senhora do Destino (Globo, 2004), a personagem Nazaré (Renata Sorrah) ganhou todo o destaque na trama e é, talvez, a vilã mais bem construída na história da teledramaturgia brasileira. Apesar de sequestradora, assassina e golpista, Nazaré demonstrava um amor incondicional a sua filha sequestrada Isabel (Carolina Dickman). É sintomático encontrar no orkut ${ }^{81}$, uma das maiores redes de relacionamento e grande sucesso no Brasil, comunidades como "nós amamos Nazaré Tedesco", "eu amo a Nazaré Tedesco" e "sou fá da Nazaré Tedesco", entre outras. Em que pese a Nazaré ser uma vilã amada por suas maldades, ela teve um final tradicional: a morte. Entretanto, ao contrário do que previa o folhetim clássico, alguns vilões não são punidos no final, como a personagem Bia Falcão (Fernanda Montenegro) em Belíssima (Globo, 2005) que, depois de ter cometido as mais diversas maldades como odiar e recusar a própria filha, termina num quarto de hotel em Paris ao lado de um rapaz muitos anos mais jovem. Em Duas Caras (Globo, 2007), dois vilões não foram punidos; ao contrário, se deram muito bem no final da trama: Silvia (Alline Moraes) e Marconi Ferraço (Dalton Vigh). Ferraço dá um golpe em Maria Paula, rouba toda sua fortuna e foge sem saber que Maria Paula está grávida. Após dez anos, Maria Paula dá conta do paradeiro de Ferraço através de uma reportagem de televisão e parte para a vingança. O que ela não contava é que Ferraço usaria o filho Renato (Gabriel Sequeira) para tentar neutralizá-la. Mas à medida que a trama avança, Ferraço se dá conta do amor que sente pelo filho e passa a se humanizar e a se arrepender dos crimes cometidos. Temendo perder o amor de Ferraço, Silvia sequestra Renato e acaba por sofrer um acidente após perseguição da

80 Ver Vilão bom é vilão morto. Disponível em: http://puc-riodigital.com.puc-rio.br/media/1\%20\%20vil\%C3\%A3o\%20bom\%20\%C3\%A9\%20vil\%C3\%A3o\%20morto.pdf acesso: 23/01/2010.

81 Foram encontradas 63 comunidades no orkut com a ferramenta de busca "Nazaré Tedesco". Acesso em $23 / 01 / 2010$. 
polícia. No final, assim como Bia Falcão em Belíssima, Silvia termina em Paris, namorada de homem milionário e amante secreta de João Batista (Júlio Rocha), seu ex-motorista. Ferraço, após cumprir dois anos de prisão, descobre que Maria Paula fugiu com o todo o dinheiro e com o filho do casal. Mas a vingança de Maria Paula não dura muito tempo: Ferraço recebe um telefonema de Maria Paula pedindo que ele vá ao encontro dela e de seu filho terminando assim, a novela, juntos.

Em A Favorita (Globo, 2008), o então autor estreante no horário das 21 horas, João Emanuel Carneiro, inova ao deixar no ar quem seria a vilã da trama: Flora (Patrícia Pilar) ou Donatela (Claudia Raia)? Tudo levava a crer, no início da trama, que Flora era a "mocinha" e Donatela a "vilã". Mas o público foi surpreendido quando foi revelado exatamente o contrário: que a vilã era a Flora. Com frases como "aquela vaquinha", "aquele purgante", Flora se referia à própria filha. Em outros tempos, esse comportamento, provavelmente, chocaria o público que torceria por sua severa punição. Mas assim como as maldades de Nazaré, Flora também tinha um tom humorístico, às vezes beirando a loucura, quando planejava suas maldades.

Outro aspecto de desconstrução que podemos apontar na telenovela brasileira é a presença das classes sociais mais baixas nas tramas através da representação das favelas. De um certo modo, a telenovela sempre procurou contemplar as diferenças entre as classes sociais construindo tramas que, entre outras questões, tratavam da mobilidade social. Mais recentemente, já no período das novelas híbridas, a teledramaturgia brasileira passou a representar a periferia dos grandes centros urbanos através das favelas:

Incrustadas nos morros cariocas, esparramadas pelas periferias de São Paulo, suspensas nos alagados de Salvador, as favelas são parte integral da paisagem urbana brasileira. Essa presença da habitação informal, pobre e precária em meio à trama urbana sedimentou um vasto repertório de representações que foram modificando-se ao longo das décadas. Mas, a despeito da diversidade de abordagens, há sempre o registro do descompasso entre os anseios da modernização social e a presença da favela colocando em pauta as contradições das metrópoles e a própria viabilidade da cidade e dos ideários da modernidade. (Jaguaribe, 2007, p. 125)

Em Vidas Opostas (Record, 2006), escrita por Marcílio Moraes, a população de uma favela carioca se revolta contra os traficantes que dominam o morro e contra a polícia corrupta. Sucesso de audiência, essa trama mostrou a cidade do Rio de Janeiro por um outro ângulo: a dos marginais, do tráfico de drogas e dos conflitos da favela. A novela parte de uma 
tradição melodramática básica onde Joana (Maytê Piragibe), uma jovem humilde, se apaixona por Miguel (Léo Rosa), um homem rico. Ela, pobre e moradora numa das muitas favelas do Rio de Janeiro. Ele, morador de um bairro nobre. O impacto dessa trama pode ser ilustrado pela extrema violência e desigualdade social como contexto. O mérito fica por conta do grau de "realismo" que a equipe cuidou de imprimir na tela, gravando, por exemplo, a favela em locações reais sem a interferência de cidade cenográfica.

No ano seguinte, em 2007, a favela ganhou o horário nobre das 21 horas na TV Globo na novela Duas Caras, escrita por Aguinaldo Silva. Batizada de Portelinha, a favela tinha como líder da comunidade Juvenal Antena (Antonio Fagundes), personagem de pulso firme que lidera a comunidade e se orgulha de ter construído uma favela modelo na qual não há espaço para a violência e o tráfico de drogas. Ao contrário de Vidas Opostas, na Record, que gravou cenas da novela em locação, a TV Globo ambientou a fictícia favela da Portelinha no Projac em um espaço de 6 mil metros quadrados e construiu mais de 100 casas no local. Em um determinado momento da trama, a Portelinha vira ponto turístico, atraindo visitantes de vários locais do mundo. Salientamos que o turismo da ficção, representado na novela Duas Caras é, de fato, praticado em algumas favelas cariocas. Segundo Jaguaribe (2007, p. 125), no Rio de Janeiro, há visitas vendidas às favelas cariocas como forma de experiência do "the real thing”. Trata-se dos favela tours, organizados em três modalidades: Favela tour, jeep tour e Exotic tour. Tais incursões não se limitam à favela da Rocinha, mas também a outras comunidades como a de Vila Canoas.

Como compreender que a pobreza urbana se torne um atrativo turístico na modernidade tardia? Pobreza urbana esta, diga-se de passagem, que não é prerrogativa dos países do "terceiro mundo", mas que também é empacotada para olhos turísticos em Los Angeles, Nova York, Londres, assim como Buenos Aires, Rio de Janeiro e tantas outras metrópoles. A vendagem dos favela tours cariocas somente pôde ser bem sucedida porque é parte de um anseio pela visitação aos locais "reais" que se tornou um macro da indústria turística no mundo globalizado. Um mundo saturado de mediações midiáticas, um mundo onde a homogeneização expressa nas cadeias de hotéis, lojas estandardizadas, locais de fast foods e shopping malls faz parte daquilo que o antropólogo francês Marc Augé denominou como sendo os "não lugares" da modernidade tardia. Por "não lugar", Augé designa espaços urbanos tais como aeroportos, parques temáticos ou shoppings malls que estão determinados por seus princípios de funcionalidade e carentes de personalização singular. (Jaguaribe, 2007, p. 139-140)

O Favela toor da Portelinha foi idealizado pela personagem Eva (Letícia Spiller) que, 
junto ao seu marido Gabriel (Oscar Magrini), organizava visitas à favela com a anuência de Juvenal Antena, que autorizou o favela toor mediante comissão de participação nos lucros. Com um jeep preparado para as difíceis incursões nos terrenos irregulares da favela, Eva e Gabriel usavam figurinos oferecendo "ares” de aventuras do clássico Indiana Jones.

Em Viver a Vida (Globo, 2009/2010), a favela ganha espaço através dos personagens Sandrinha (Aparecida Petrowsky) e Benê (Marcello Melo), um jovem negro contraventor e foragido da polícia. Gravadas no morro Dona Marta, zona sul do Rio de Janeiro, as cenas extrapolaram as fictícias cidades cenográficas do Projac, buscando criar um certo grau de veracidade da ficção. Visivelmente diferente das outras ambientações da novela, as imagens da favela foram gravadas e exibidas em HDTV destoando das demais imagens. Esse recurso, talvez, tenha sido usado para conferir à telenovela uma qualidade de imagem próxima a do cinema que, em sua história mais recente, trouxe a periferia, a favela, os pobres, contraventores e excluídos sociais à suas telas através de filmes como Cidade de Deus (2002), Carandiru (2003) e o documentário Ônibus 174 (2004). "Estes filmes reforçam como a mídia se torna real, e a vida se ficcionaliza; como a presença da câmera deslancha eventos e como o sentido do real é obtido por meio de recursos dramáticos da mídia visual”, afirma Jaguaribe (2007, p. 119). Note-se que até mesmo o nome do personagem Benê faz referência a um dos personagens do filme Cidade Deus, no qual Benê é interpretado por Phelipe Haagensen, ator morador da favela do Vidigal no Rio de Janeiro. O ator Marcello Melo, intérprete de Benê em Viver a Vida, também foi ator nos filmes Cidade de Deus e Última Parada 174.

Jaguaribe (2007) aponta uma interessante reflexão acerca dos filmes de estéticas mais "realistas", como Cidade de Deus e Ônibus 174, entre outros. Ao fazê-la, aponta implicitamente a noção de desconstrução, com o consequente rompimento de dicotomias ou inversão de tradicionais hierarquias:

Enquanto as telenovelas ainda retratam, em grande medida, os romances e as expectativas das classes médias urbanas, as expressões literárias e cinematográficas realistas têm privilegiado os pobres, os marginais e os excluídos. Desta forma, se a telenovela muitas vezes possui uma certa pedagogia "civilizatória" do normativo português, os filmes e narrativas aqui citados recaem no cânone contrário, na perspectiva da retratação crítica da exclusão social, enfocando não o drama da consciência burguesa, mas a vida precária dos despossuídos. (Jaguaribe, 2007, p. 121)

Justiça seja feita à telenovela: se no passado as telenovelas representavam quase que 
exclusivamente o modo de ser e viver da classe burguesa ou das classes médias urbanas, hoje restam provadas que as constantes inovações em curso na telenovela passam pela desconstrução de paradigmas tradicionais, muitas vezes herdados do folhetim clássico. Tal desconstrução implica em apontar a evidente "voz" que os excluídos sociais, minorias étnicas, raciais e sexuais passaram a ter nas narrativas contemporâneas.

Outro ponto a ser destacado, nesse sentido, é o fato de atores negros marcarem cada vez mais presença não só no cinema como também no horário nobre da telenovela. Se tradicionalmente as telenovelas mostravam o negro como uma pessoa humilde, sem instrução e com poucas perspectivas profissionais, na contemporaneidade, os negros ou descendentes estão sendo representados de outro modo. A personagem Helena (Tais Araújo) de Viver a Vida representa a primeira protagonista negra em uma novela das 21 horas na história da teledramaturgia brasileira: ela é bonita, rica e modelo internacional de sucesso. A mesma atriz, anteriormente, já havia sido a personagem principal da novela Xica da Silva (Manchete, 1996, 1997) e protagonista da novela das 19 horas Da cor do Pecado (Globo, 2004). Nessa novela, ela era Preta, uma moça pobre que manteve um relacionamento inter-racial e de classe social distinta com Paco (Reynaldo Gianecchini). Notamos que os relacionamentos interraciais tornaram-se cada vez mais constantes nas telenovelas. Somente na novela Duas Caras, em 2007, houve cinco casamentos inter-sociais e inte-raciais:

Especial atenção é dada aos arranjos familiares inter-raciais e inter-classistas, e aos relacionamentos não tradicionais, como um triângulo amoroso assumido publicamente. A multiculturalidade religiosa também está expressa na representação de uma comunidade evangélica e de uma comunidade de candomblé, ambas com as suas práticas e os seus rituais. (Lopes, 2008)

\subsection{Telenovela brasileira entre a ficção e a realidade.}

É interessante notar como a imprensa especializada, sobretudo os jornais impressos, tem publicado constantemente críticas à telenovela brasileira destacando a interferência do "real" em suas tramas. Dentre elas, destacamos: "Dos Jornais para os folhetins - autores se inspiram em fatos reais para a elaboração das tramas na teledramaturgia". ${ }^{82}$ Nesse artigo, o jornalista faz referências ao último capítulo da novela Paraíso Tropical (Globo, 2007) de 
Gilberto Braga, comparando a personagem Bebel, interpretada por Camila Pitanga, com Mônica Veloso ${ }^{83}$, fazendo alusão aos últimos escândalos envolvendo políticos em Brasília. Neste mesmo artigo, há uma referência à novela Duas Caras (Globo, 2007, 2008), de Aguinaldo Silva, que admite que o personagem interpretado por Dalton Vight foi inspirado em José Dirceu, ex-chefe da Casa Civil que viveu um tempo exilado em Cuba e fez cirurgia plástica passando a viver na clandestinidade com outro nome. Nessa mesma novela, um outro exemplo que pode ser apontado é a questão do escândalo dos cartões corporativos envolvendo também políticos em Brasília, no ano em que Duas Caras foi exibida: a personagem Branca, interpretada por Suzana Vieira, foi afastada de seu cargo na fictícia Universidade Pessoa de Moraes, da qual também era proprietária, por usar o cartão da empresa em benefício particular. A telenovela, nesse sentido, cumpre uma função pedagógica porque, afinal, do que se tratam os tais cartões corporativos e por que é errado o uso em benefício próprio? Assim, a telenovela parece cumprir um papel tradicionalmente designado aos telejornais:

Considerem-se, a título de ilustração, os noticiários e as novelas de TV, em que assiste a uma perfeita inversão de papéis. Não se pensa, aqui, no modo de operar da mídia brasileira, da fabricação de fatos, da "edição da realidade". Das três "razões sociais" da mídia - informação, entretenimento, cultura - e nenhuma se cumprindo, como esclarecimento, poder-se-ia dizer que estes se tornam ficcionais. No final dos anos 1980, a novela Roque Santeiro marcou época, sobretudo na personagem de Lima Duarte. O Brasil da "Nova República", recém saído de uma ditadura militar, agora com liberdade de expressão, encontrou não a "verdade" nas transmissões "ao vivo", mas em sua desrealização: a novela "era mais realista que o noticiário. O gênero que mais de perto deveria retratar o que acontece dizia inverdades. Já o gênero que, por definição, inventa, era mais realista em face da sociedade brasileira. (Matos, 2009, p. 15)

Podemos afirmar que a telenovela brasileira contemporânea tem se sofisticado não só em qualidade de produção técnica, mas como também de narrativa, na medida em que propõe múltiplas temáticas numa mesma obra, aumento de número de personagens e, sobretudo, combinações com outros gêneros e linguagens que nos permitem pensar a telenovela como um formato híbrido. Com efeito, esta investigação parte de uma hipótese central onde é possível aproximar estas relações entre o factual e o ficcional na telenovela brasileira com o gênero híbrido conhecido como docudrama.

Sem a pretensão de se aprofundar em questões filosóficas ou mesmo de intervir ou

83 Ex-apresentadora de televisão que se envolveu em um escândalo de corrupção envolvendo o então Senador da República Renan Calheiros. 
questionar as investigações de outros formatos e gêneros como os documentários e realityshows, propomos, a seguir, um quadrado semiótico para analisar a clássica oposição ficção vs realidade. Entendemos que a investigação desta dicotomia é central para a compreensão das transformações das narrativas das telenovelas e no avanço da hipótese de que o docudrama se apresenta como uma meta-categoria da telenovela.
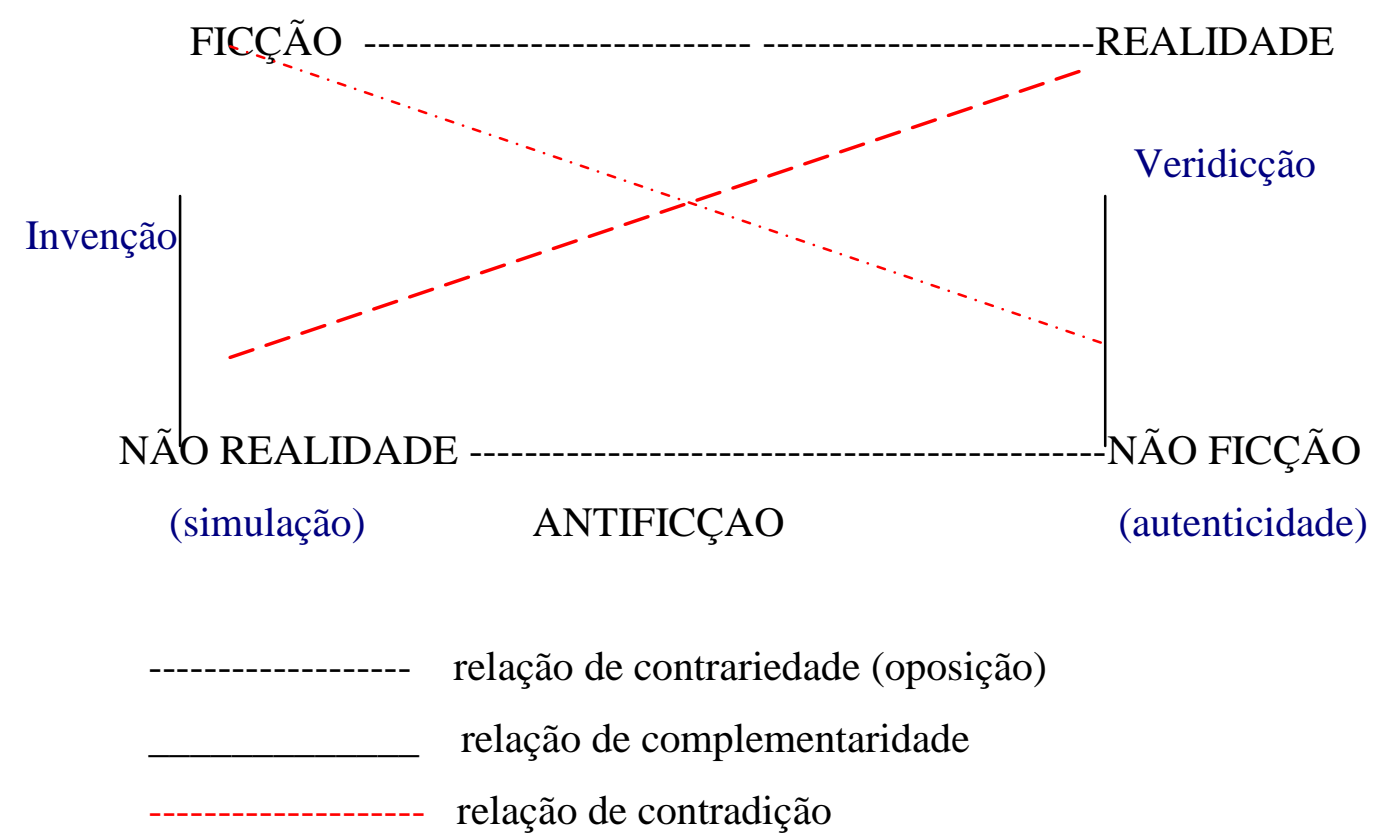

A antificção pode ser definida como algo que está entre a não realidade e a não ficção. Nessa categoria estão, por exemplo, os docudramas e os realityshows, que podem ser percebidos como algo que transita entre a simulação e a autenticidade. A ficção é uma invenção e uma simulação de algo (não real); nessa categoria, podemos apontar, de um certo modo, as telenovelas tradicionais e os filmes que se manifestam como ficcionais. Já os gêneros ou formatos que buscam tratar a "realidade" - documentários, telejornais ou noticiários de uma maneira geral - se interessam pela vericidade e a autenticidade dos fatos históricos e sociais. Ressalvamos que este quadrado semiótico não pretende, em momento algum, dar conta de todas as variações e combinações possíveis entre as oposições (ficção vs realidade) e seus contraditórios (Não ficção vs não realidade). Ele foi construído para nos auxiliar no processo de compreensão dos mecanismos de funcionamento de um docudrama e como a telenovela ultrapassa a categoria de ficção porque passa a tratar da "realidade" em suas narrativas. Confrontar as oposições (ficção vs realidade) com seus contraditórios resultou 
em questões bastante interessantes e particularmente importantes para essa investigação: a simulação e a autenticidade são ideias que se hibridizam e se misturam em um docudrama. Como vimos, em tradicionais docudramas como o programa Linha Direta, os créditos convidam o espectador a ler a produção como simulação (não real), ao mesmo tempo que busca criar mecanismos discursivos que a auxiliam a construção da autenticidade através de referentes (depoimentos, fotografias, imagens de arquivo de família, datas, etc).

A telenovela, ao ultrapassar as fronteiras da ficção, deixa de ser um formato que apenas produz narrativas frutos de "invenções" imaginadas por determinados autores. Assim concebida, passa a transitar em um outro lado do quadrado semiótico: o da antificção, se posicionando, também, entre a não realidade (simulação) e a autenticidade (não ficção). Isso fica ainda mais evidente quando nos deparamos com cenas produzidas em consonância com fatos históricos e sociais de amplo conhecimento público que misturam, propositalmente, ficção e não ficção. Como veremos mais adiante, há uma cena em Páginas da Vida (Globo, 2006), na qual há uma simulação, resultante da manipulação de sofisticados recursos de edição e de computação, que coloca a personagem interpretada por Sonia Braga "dentro" das cenas reais dos ataques às torres gêmeas ocorrido em 11 de setembro de 2001. A seguir tentaremos, empiricamente, ilustrar o como a telenovela brasileira aproxima-se do gênero docudrama ao produzir cenas antificcionais.

\subsection{Docudrama em $O$ Clone}

Apontamos a novela $O$ Clone, exibida de outubro de 2001 a junho de 2002 na Rede Globo, como a obra que marca o início do que chamamos de novelas híbridas. De maneira mais evidente, a trama foi localizada simultaneamente em dois países de tradições e culturas extremantes distintas: Brasil e Marrocos. Inicia-se a partir daí uma sequência de novelas produzidas no exterior. As duas novelas posteriores de Glória Perez não foram exceção: América (Globo, 2005), Brasil e Estados Unidos, e Caminho das Índias (Globo, 2009), Brasil e Índia. Como parte integrante de seu estilo dramatúrgico e marca registrada de suas obras, Glória Perez se inspira em um tema científico e polêmico, a clonagem humana:

O tema da clonagem humana surgiu porque, desde o nascimento da Dolly, eu fiquei imaginando como seria um clone humano, como ele se sentiria no mundo e como as pessoas olhariam pra ele, por causa da questão da identidade. O tema da clonagem humana já puxou o universo muçulmano pra 
novela porque quando você fala em um homem criando a vida em laboratório já vem logo a ideia de Deus, de uma humanidade ocidental que quer superar Deus, já se declarou até que Deus está morto, tomando para si a criação da vida em contraponto com a outra parte da humanidade, a oriental, que é completamente submissa a Deus e daí a origem da palavra muçulmano. Então o universo muçulmano entrou aí pra servir de contraponto a isso e, quando você fala em clone, não tem como você não falar da questão da identidade. Eu achei que a melhor maneira de abordar seria que esse clone surgisse no sentido de substituir alguém, porque essa é a primeira ideia que as pessoas têm quando fala em clonagem, clonar alguém que já existe, dizer que fulano de tal mereceria ser clonado e tudo o mais. Então eu pensei em gêmeos, o que já é uma forma difícil de convivência. Pesquisei vários gêmeos, a questão da identidade é muito complicada neles. Então eu observei que nos gêmeos tem sempre um que é o dominante e o outro é o mais dependente e que, aos olhos dos outros, eles formam como uma figura só, isso é muito incômodo..E muito comum por exemplo que os gêmeos não tenham nome. Pra muitas pessoas, elas se referem "os gêmeos" ou então se os gêmeos se chamam Diogo ou Lucas, inclusive o Lucas falou sobre isso na novela, eles falam Diogo Lucas, como se fossem uma pessoa só. Eles formam para os outros uma imagem única. E isso dá um conflito de identidade muito grande, então o Lucas foi construído assim, como sendo aquele que era o mais subordinado, aquele que não conseguia descobrir quem ele era, que já é complicado para um adolescente ainda mais quando ele é visto assim. E o Diogo era aquele que dava o tom da dupla, que definia, ele se colocava mais, ele era mais objetivo, mais nítido aos olhos dos outros. E aí quando o Diogo morre, o Lucas entra numa crise de identidade muito grande, muito profunda, inclusive achando que o pai deveria achar que talvez, se ele morresse, não faria tanta falta quanto o outro, porque o outro tinha mais sensibilidade pras pessoas, ele se sentia meio que como um apêndice do Diogo ${ }^{84}$.

Pela primeira vez, pessoas "reais", vítimas das drogas, "interrompiam" uma cena de ficção para relatar seus dramas e superações. Nesta sequência que selecionamos como amostragem, a personagem $\mathrm{Mel}$ (Débora Falabella) compartilha com outra personagem, Regininha (Viviane Victorete), problemas familiares em comum decorrentes do uso das drogas:

Mel: - Eles não me deixam viver, sabe? Eles ficam me sufocando, Toda hora tão lá em casa botando defeito em tudo, falando que eu não devia tá com o Xandy, que a gente não devia morar no lugar onde a gente mora .

Regininha: - Quem tem que gostar é você, não são eles.

Mel: - Eu sei, eu também acho.

Regininha: - Família é tudo igual. Eu não tenho saco pra família não, viu? Minha mãe,

\footnotetext{
${ }^{84}$ PEREZ, Glória. Entrevista concedida ao autor. Curitiba. 30 junho, 2003.
} 
também, ficava querendo regular minha vida, querendo me domesticar. Ninguém me domestica não, qual é? Eu achei até bom quando ela me botou pra fora de casa, quer saber? Mel: - Ela botou, foi?

Regininha: - Botou, mas eu não tô nem aí.

Mel: - Ai... agora minha mãe quer que eu volte pra casa dela com o Xandy, mas isso é só pra terminar mais rápido o nosso namoro.

Nesse momento, a ficção é interrompida. Há um fade - a imagem escurece - e um efeito sonoro é inserido causando uma sensação dramática. Com o "gancho" da ideia de família ou dos problemas familiares resultantes do uso das drogas, um "anônimo", usuário de drogas em tratamento, relata sua luta e a vontade de sobreviver à doença. Conforme já pontuamos, as pessoas, vítimas das drogas, que deram seus depoimentos em $O$ Clone, foram enquadradas em superclose ou planos de detalhe para que seus rostos não fossem identificados. O efeito dramático dessas cenas foi assegurado pelas evidentes expressões tristes dos depoentes e das irreversíveis sequelas pelo uso contínuo das drogas. No caso do depoente a seguir, chama muito a atenção o detalhe de suas mãos que não param de tremer.
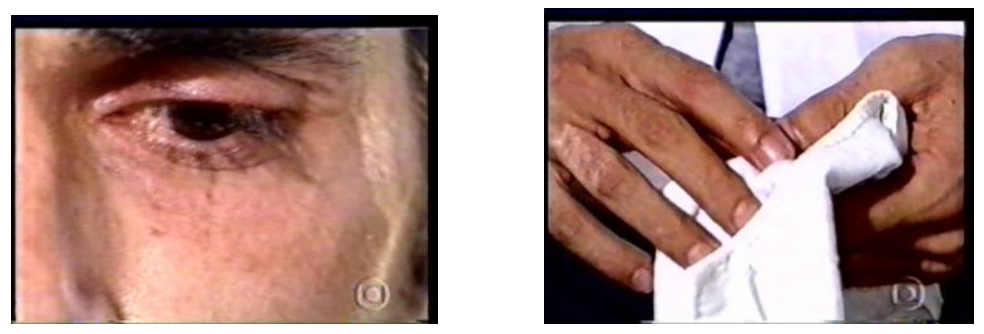

Eu comecei muito cedo. Quando eu tinha 14 anos de idade, eu comecei a beber, vim a conhecer a maconha, fumava maconha descaradamente dentro do colégio. Tudo era fácil porque meus pais não sabiam. Eles me davam dinheiro para pagar o colégio, eu não pagava o colégio. Eu ia me drogar. Eu tive a infelicidade de conhecer a heroína. A crise de abstinência da heroína te deixa completamente inábil a fazer nada, você não consegue fazer nada, você sente dor nas pernas, você sente dor na coluna, você sente dor na cabeça, nos braços, você sente calafrio, começa a suar frio, então você tem que usar ela para você estar num estado normal. Porque a heroína no começo é muito prazeroso, né? Mas chega um certo estágio, uma semana de uso, você já tem uma crise de abstinência muito forte. Eu perdi a confiança dos meus pais, perdi a confiança das minhas irmãs, tudo lá em casa é trancado, eu vendi tudo, roubei muito a minha mãe, roubei muito o meu pai. 
A minha família sempre foi muito carinhosa comigo e eu nunca correspondi, né? Devido à falta de sentimentos, a droga faz que você perca todos os sentimentos né? Eu roubei vizinho, eu só não matei, né? Ainda. Eu perdi tudo na minha vida. Eu tenho que começar do zero e eu tenho muito medo disso.

Semelhante a uma autobiografia, esses relatos exprimem os sentimentos e dilemas de pessoas "desconhecidas" que, muito provavelmente, não teriam nenhum espaço para expor seus pensamentos:

Escrever e publicar a narrativa da própria vida foi por muito tempo, e ainda continua sendo, em grande medida, um privilégio reservado aos membros das classes dominantes. O "silêncio" das outras classes parece totalmente natural: a autobiografia não faz parte da cultura dos pobres. Contudo, há cerca de 10 anos, uma nova técnica, a dos relatos de vida coletados pelo gravador e publicados em formato de livro, coloca à disposição do público a voz dos camponeses, artesão e operários. A "palavra é dada" a eles - ou seja, tomada deles para ser transformada em escrita. A origem desse movimento parece ter sido o método etnográfico aplicado por sociólogos às classes dominadas de nossas sociedades. (Lejeune, 2008, p. 113)

Ao término do depoimento, há outro fade para a continuação da cena ficcional anterior:

Regininha: - Eu tava precisando tanto dar um teco ${ }^{85}$.

Mel: - Eu também, viu? Eu falo da minha mãe e me dá logo a vontade de dar um teco.

Regininha: - Vamo embora?

Mel: - Ah, Regininha, eu combinei com o Xandi aqui.

Regininha: - Rapidinho.

Mel: - Tá, mas só se for bem rapidinho...

Regininha: - Não... rápido.

Mel: - Então, vamos.

Notamos que esse procedimento narrativo de misturar ficção e realidade da novela $O$ Clone aproxima-se da estrutura do docudrama porque contempla as características fundamentais do gênero, em outras palavras, nos permite operacionalizar a leitura docudramentarizante através de: 1.Uso de referente (depoimentos e relatos de pessoas 
"reais") que acaba por estimular o espectador a tomar o depoente como enunciador real conferindo uma autenticidade do que está sendo dito e que, portanto, trata-se de alguém que não faz parte da ficção. 2. Leitura fictivizante: evidente mistura com elementos da ficção. $\mathrm{Na}$ ficção, a personagem Mel (Débora Falabela) encena dramas "reais" baseados nos relatos, como Glória Perez afirma na entrevista: “eu resolvi entrevistar também os país e os familiares, então, por exemplo, a cena em que a Maysa sobre o morro pra pagar a dívida da Mel, os pais contavam isso, então eu fiz ela subindo”. Apesar de o espectador recusar a ler a personagem Mel como enunciador real porque se sabe de antemão que ela não é real, ele percebe claramente que é uma simulação de algo baseado em fatos da realidade e 3. Melodrama: evidentemente esses depoimentos contemplam dramas familiares que, em última instância, devem ser superados para restabelecer a ordem familiar evitando, assim, sofrimento de qualquer espécie. Traz, ainda, implícita a ideia de que o uso das drogas traz consequências irreparáveis, tanto para os usuários, quanto para seus familiares, deixando uma mensagem de "lição de moral” rogando pelo não uso dessas drogas.

Notamos que esta forma de narrar - com inserção de depoimentos - foi inaugurada na novela $O$ Clone e seguida por outras obras das novelas híbridas: Páginas da Vida e Viver a Vida, ambas escritas por Manoel Carlos.

\subsection{Docudrama em Páginas da Vida: a representacão do 11 de Setembro}

Páginas da Vida estreou no horário das 21h da TV Globo no dia 10 de julho de 2006. A história central enfoca o dilema de Nanda (Fernanda Vasconcelos), uma estudante de arte que se envolveu com o namorado Léo (Thiago Rodrigues) e engravida. Diante da recusa de Léo em assumir a criança, Nanda volta ao Brasil, mas é atropelada e levada para o hospital, onde trabalha a médica Helena (Regina Duarte). Grávida de um casal de gêmeos, a moça não resiste e morre, mas Helena consegue salvar os bebês. No entanto, uma das crianças, com síndrome de down, é rejeitada por Marta (Lilia Cabral), avó materna amargurada com a vida. A médica decide adotar a criança, Clara (Joana Morcazel). O dilema de Helena será decidir se contará ou não ao pai da menina que a criança está viva e mora com ela. A trama teve início em 2001 e, em determinado momento, avançou cinco anos chegando a 2006. No capítulo 38, exibido em 22/08/2007, a novela citou os fatos amplamente noticiados em cada ano. Destaca- 
se o ataque ao World Trade Center ocorrido no ano de 2001.

No capítulo em questão, as cenas com a representação do fato histórico concentram-se no primeiro bloco, o maior em tempo de duração. No segundo bloco, há uma citação dos jogos da copa do mundo de 2002, quando o Brasil ganhou o título de pentacampeão. Os três últimos blocos são reservados para o desenrolar da trama ficcional. Cada bloco é dedicado a um ano do calendário dando conta do percurso de 2001 a 2005, chegando a 2006. Dividimos a análise também em cinco blocos, destacando o primeiro bloco, por conter a representação do fato histórico de maior relevância: os ataques de 11 de setembro. 


\section{Bloco 1:}

O capítulo inicia em Nova York, 11 de setembro de 2001.
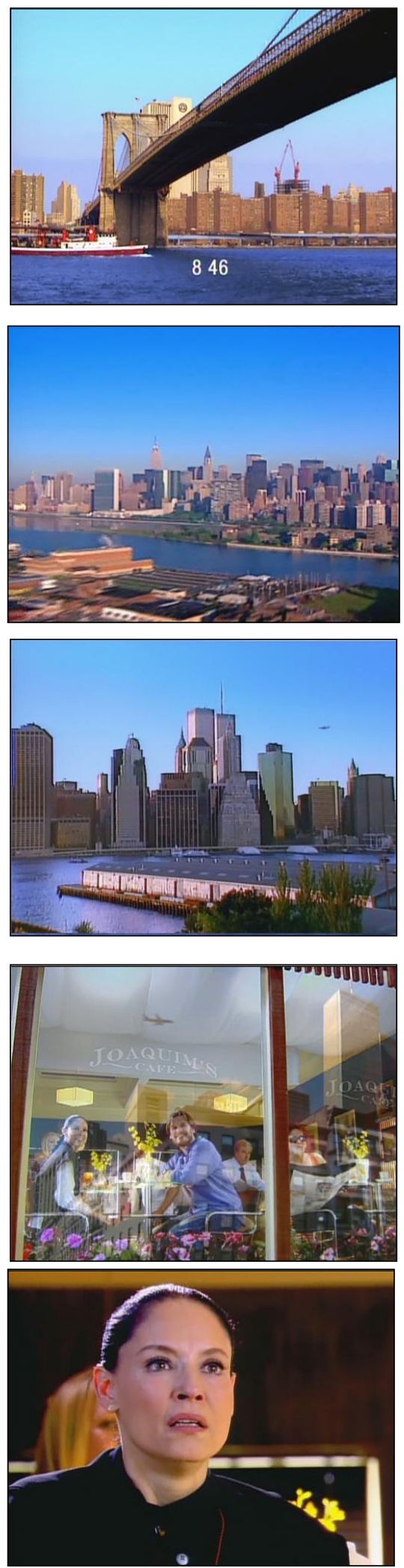

Simulação da cidade de Nova York, momentos antes da colisão. Letreiro aponta o horário.

Um câmera sobrevoa a cidade de Nova York. Temos a simulação do ponto de vista (Câmera subjetiva) do primeiro avião que colidiu com uma das torres.

Com efeitos de computador. Observamos a simulação do avião indo ao encontro do WTC.

Tonia (Sonia Braga) está numa lanchonete com um amigo. Nota-se o reflexo do avião sobre o vidro.

Reação da personagem diante do ataque. 
Aplicando a proposta de leitura docudramentarizante no trecho selecionado, o espectador é estimulado a reconhecer como enunciador real o fato histórico em si. Não resta dúvida de que o ataque às torres gêmeas representa algo da realidade. Tal fato foi noticiado ao vivo nas emissoras de televisão de todo o mundo e é considerado uma das maiores tragédias da história da humanidade. A ancoragem do tempo e do espaço (Nova York, 08h 46m) é tomada como enunciador real e busca dar um efeito de autenticidade nas informações. Evidencia-se a montagem híbrida entre o referente (imagens de arquivo do world trade center) e a inserção de uma personagem da ficção no referente como se ela estivesse naquele dia e local do fato histórico.

Após a simulação do ataque, há um corte para uma cena na qual Helena (Regina Duarte) está no hospital com Clara, bebê que tem síndrome de Down. Após a morte de sua mãe Fernanda (Fernanda Vasconcelos), Clara é abandonada pela avó materna Martha (Lilia Cabral). O grande desejo de Helena é conseguir a adoção da menina.

Essa cena resolve a principal pendência da narrativa para que o autor Manoel Carlos inicie a transição para segunda fase da novela, saltando a trama de 2001 para 2006. Desta forma, temos a cena seguinte:

Na casa de Tide (Tarcísio Meira), os familiares estão reunidos em torno da televisão, perplexos com as imagens do ataque às torres gêmeas. Ouvimos em off a narração de um repórter: 11 de setembro de 2001. A cidade de Nova York foi despertada pelo som de uma tragédia. Um avião acaba de bater em uma das torres do World Trade Center às 08h46 desta manhã, horário local. Logo o prédio começou a pegar fogo. Centenas de milhares de pessoas estavam dentro dos escritórios e se preparavam para começar mais um dia de trabalho. A paisagem da cidade foi alterada com a presença do que parecia ser uma gigantesca chaminé. Cerca de quinze minutos depois um novo estrondo. Um outro avião colidiu com a torre sul do prédio. Mais fogo.

Nota-se que o foco do texto lido em off segue a mesma estrutura de uma reportagem de televisão, acabando por criar efeito de objetividade através do uso da terceira pessoa do discurso e a constante preocupação com a ancoragem (11 de setembro de 2001, 08h06, cerca de quinze minutos depois). O relato dos acontecimentos do 11 de setembro através de um locutor/repórter em off reforça a percepção das imagens exibidas como documento, na medida em que, "tradicionalmente, é próprio ao documentário a presença de uma versão amena de 
"montagem vertical", com a voz de um locutor que, se pondo como autoridade, comenta, explica, dá as coordenadas do fato mostrado na tela”. (Xavier, 1997, p. 158)

As imagens de televisão são inseridas na edição de maneira híbrida, na qual personagens da ficção assistem algo da "realidade":
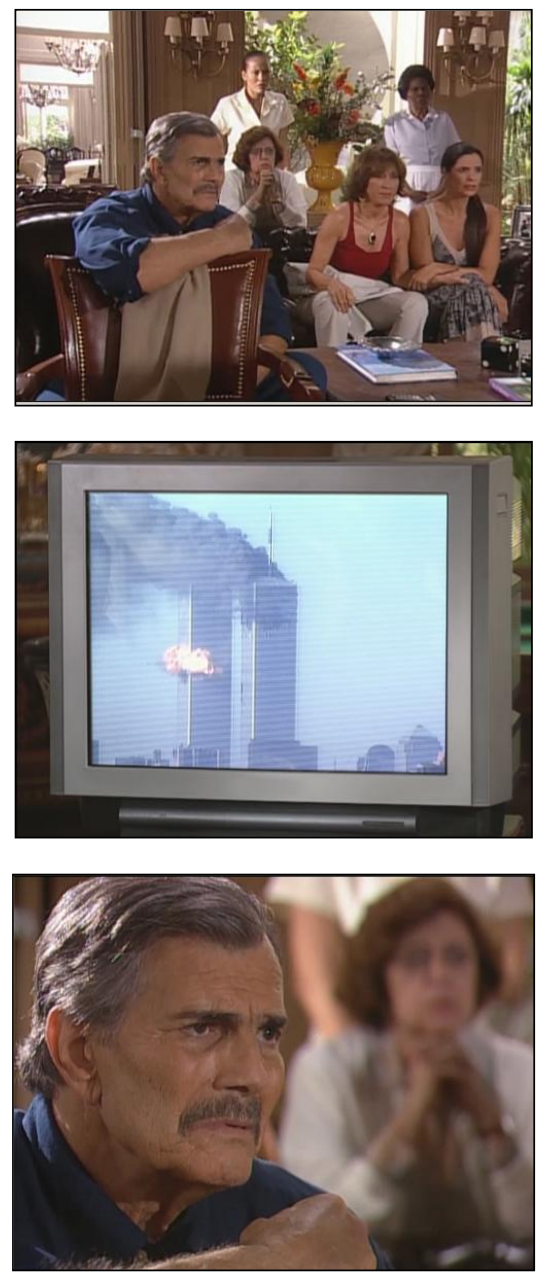

Tide (Tarcísio Meira) ao lado das filhas: Carmen (Natália do Vale) e Márcia (Helena Ranaldi) acompanham pela televisão as primeiras transmissões dos ataques de 11 de setembro de 2001.

Numa espécie de metalinguagem (televisão mostra a televisão), o espectador na novela revive 0 drama da tragédia com as imagens reais das torres gêmeas.
Tide e Constância (Walderez de Barros), atônitos com as imagens da tragédia.

Locutor/off: Os aviões, lotados de combustível, se transformaram em bombas voadoras. Em seguida, o primeiro prédio desabou. O pânico tomou conta da cidade de Nova York.

Muita fumaça. Correria e destroços. Os bombeiros foram acionados. Ainda não se tem ideia do número de vítimas. A cidade e o mundo estão perplexos tentando entender o que aconteceu. 


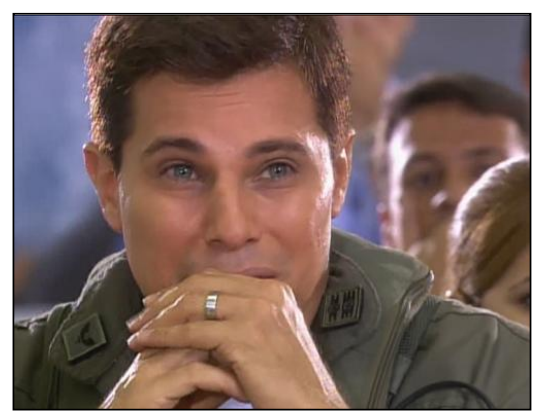

Outros personagens acompanham pela TV as notícias da tragédia. Ao lado, o personagem Silvio, interpretado por Edson Celulari.

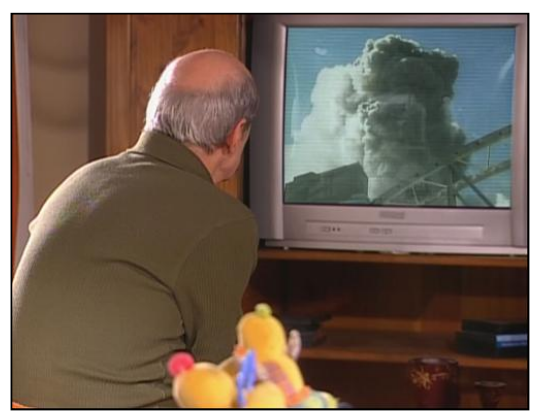

Alex (Marcos Caruso) aproxima-se do aparelho de TV. Observa a o caos que tomou conta da cidade de Nova York.

Enquanto isso, Helena, com Clara no colo, chega em casa com Salvador e é recebida pela empregada:

Empregada- Gente, está acontecendo uma coisa horrível nos Estados Unidos!

Helena - A gente ouviu comentários na rua e agora também no rádio do carro.

Salvador- É atentado terrorista.

Helena- Vamos lá pra cima. Liga a televisão do meu quarto, Salvador.
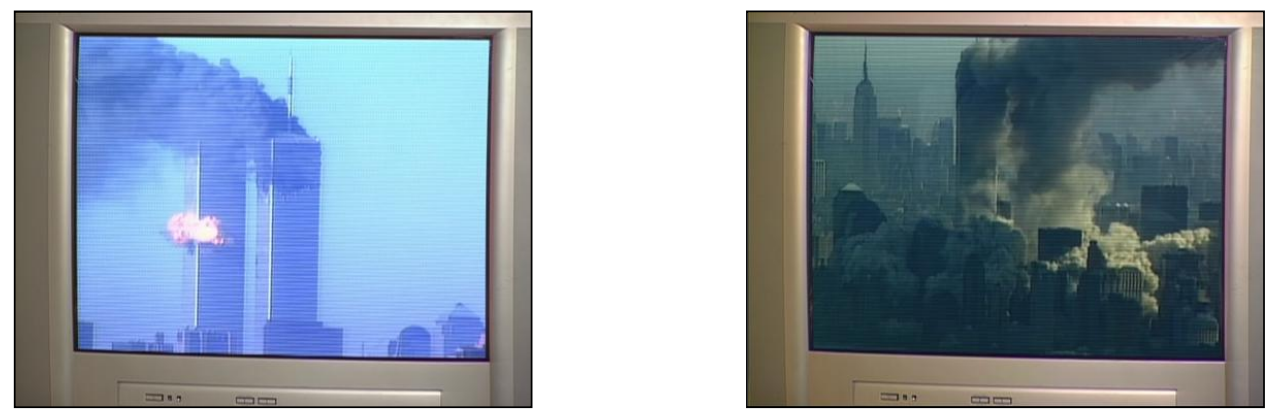

Locutor/off: Até agora não se sabe quem são os responsáveis pela tragédia. Este, talvez, seja o maior ataque sofrido pelos Estados Unidos em seu próprio território. Outras informações a qualquer momento. 


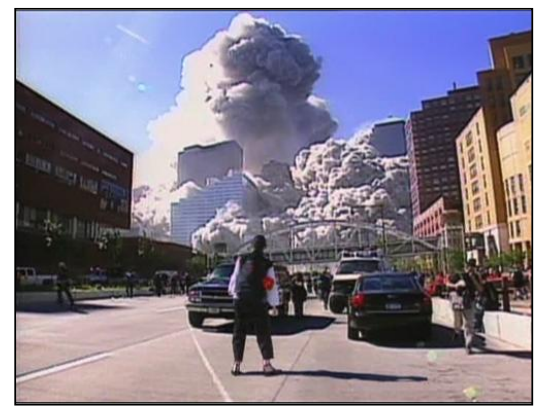

Com efeitos digitais, a encenação da personagem Tonia (sonia Braga - no centro fugindo da fumaça) é inserida nas cenas reais da tragédia, provocando uma mistura da ficção com a não ficção.

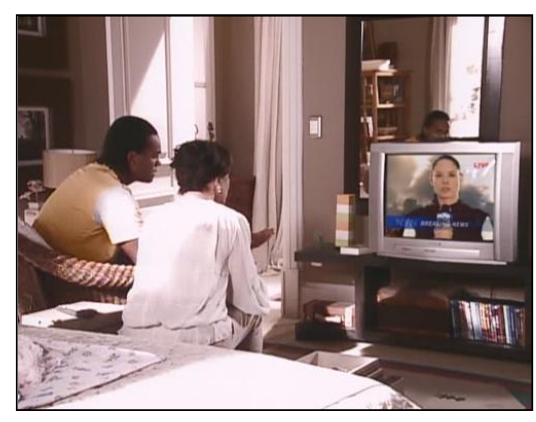

Helena e Salvador acompanhando as notícias dos ataques pela TV.

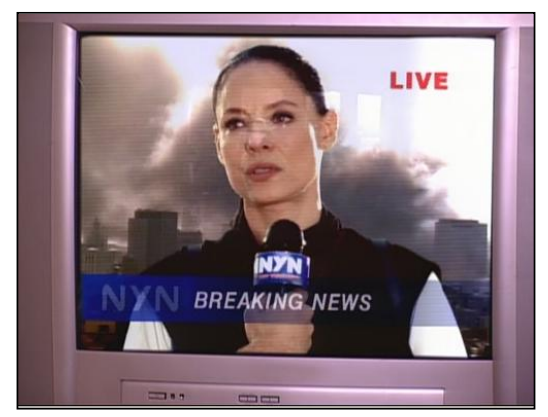

Imagem de Tonia (Sonia Braga) dando entrevista na TV americana, estilo CNN.

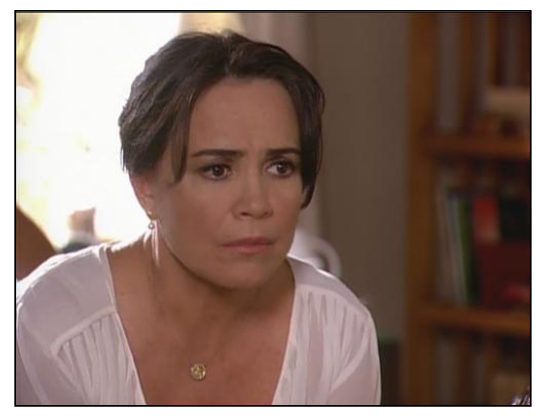

Momento em que Helena (Regina

Duarte) reconhece sua prima.

Helena: É a minha prima! É a Tonia.

Salvador: Será, mãe?

Helena: Não tenho certeza. Meus Deus! Ela está lá, me lembrei.

Salvador: Ah! Pelo menos ela está bem, tá dando entrevista tudo.

Ao mesmo tempo em que o espectador é estimulado a tomar como enunciadores reais 
o fato histórico, a autenticidade do referente (imagens de arquivo) e da ancoragem do tempo e do espaço através de datas e reconhecimento dos locais, ele reconhece a encenação de atores que compõem o elenco fixo da TV Globo recusando-se, portanto, a reconhecê-los como enunciadores reais, efetuando, assim, a leitura fictivizante. Como vimos, pode ser um docudrama um material audiovisual que contempla, em sua estrutura narrativa, características de três categorias: 1.referente, 2.leitura fictivizante e 3.melodrama. No trecho analisado, encontramos todos esses elementos. Como um típico docudrama, é espantoso, trágico e sensacionalista.

Ao término do primeiro bloco, Páginas da Vida prossegue no desenrolar dos novelos que sustentam o melodrama nos blocos 2, 3,4 e 5, conforme destacamos a seguir:

\section{Bloco 2:}

Legenda: outubro de 2001

Nasce o filho de Silvio (Edson Celulari) e Olívia (Ana Paula Arósio).

Helena comemora o primeiro natal ao lado de Clara, filha adotada.

Marta (Lilia Cabral), Alex (Marcos Caruso) e Sérgio (Max Fercondini) comemoram o primeiro natal ao lado do neto Francisco (irmão de Clara).

Legenda: dezembro de 2001 (Avistamos Copacabana e os tradicionais fogos saúdam: "salve 2002")

Fim de Bloco: corta para vinheta de passagem

\section{Bloco 3:}

Legenda: março de 2002

Helena (Regina Duarte) ouve a sentença que permite a adoção de Clara.

Renato (Caco Ciocler) lança seu livro sobre fotografia de paisagens da miséria brasileira.

Legenda: 30 de junho de 2002

Família de Tide (Tarcísio Meira) assiste ao jogo do Brasil. Ano em que a seleção ganhou o pentacampeonato. Imagens de arquivo do último jogo da copa de 2002 entre Brasil 
e Alemanha são inseridas.

Clara comemora um ano de vida.

Greg (José Mayer) casa-se com Carmen (Nathália do Vale)

Legenda: dezembro de 2002.

Gustavo (Antonio Caloni), bêbado, discute com sua mulher Márcia (Helena Ranaldi) e morre numa batida de carro digna dos filmes hollywoodianos.

Fogos em Copacabana: Salve 2003.

Corta para: vinheta de passagem.

\section{Bloco 4:}

Legenda: 20 de janeiro de 2003. Dia de São Sebastião. Padroeiro da cidade.

Tide (Tracisio Meira) inaugura o AMA - casa de cultura.

Legenda: outubro de 2003

Silvio (Edson Celulari) e Oliva (Ana Paula Arósio) comemoram novo apartamento

Renato (Caco Ciocler) e Lívia (Ana Furtado) viajam para a Inglaterra e deixa Isabel (Vivianne Pasmanter) com ciúmes.

Miroel (Ângelo Antonio) e Anna (Deborah Evelyn) se divorciam

Corta para: vinheta de passagem;

\section{Bloco 5:}

Vinícius (Sidney Sampaio) e Sabrina (Leandra Leal) decidem voltar de Amsterdã para o Brasil

Fogos: salve 2005 fusão para: Fogos: Salve 2006.

Tide está com sua família comemorando a entrada do ano de 2006.

FIM de capítulo. Créditos finais.

É notável o uso dos letreiros indicando datas durante todo o capítulo. Eles servem não apenas para localizar o espectador no tempo e espaço da narrativa, mas como também provocam a sensação da passagem de um tempo histórico, na medida em que o leitor/espectador completa a informação e compreende que o tempo está avançando. É como que se, até ali, tudo estivesse em flashback. A audiência sabe de antemão que o tempo 
avançará até o presente, período contemporâneo ao do receptor, dando uma sensação de "páginas sendo viradas", deixando os fatos no passado.

\subsubsection{Estrutura de relatos e depoimentos: Incêndio de um ônibus no Rio de Janeiro e a morte brutal do menino Hélio}

As relações com o "real" em Páginas da Vida não se resumiram a citações de fatos históricos ou notícias factuais. Diariamente e no final de cada capítulo, portadores de síndrome de down, homossexuais assumidos, filhos de pais alcoólatras, pais que perderam seus filhos choraram diante da câmera relatando seus dramas. Sempre em primeira pessoa, o entrevistado dava o depoimento de sua vida olhando diretamente para a câmera. Com o discurso quase todo construído em primeira pessoa, os entrevistados eram enquadrados numa espécie de "moldura" que deixava transparecer no fundo a imagem meio desfocada de alguma parte da cidade do Rio de Janeiro. Tal procedimento narrativo, em certa proporção, assemelha-se com a técnica do cinema direto, na medida em que

(...) ao se colocar disponível para uma experiência desta natureza - querer-se filmado, saber-se filmado, atuar diante da câmera sem um plano preestabelecido, liberar a memória e a imaginação - cada um dos "atores" embarcava efetivamente na aventura do cinema direto (Da-Rin, 2004, p. 120)

Dois desses relatos chamaram muita atenção por se tratarem de crimes bárbaros que chocaram o país na época que a novela foi exibida: um assalto a um ônibus no qual os criminosos atearam fogo e o caso do menino João Hélio, que foi arrastado por um carro preso ao cinto de segurança por sete quilômetros. É interessante notar que esses relatos foram ao ar em capítulos sequenciais intensificando o caráter dramático da novela. Em 28/12/2006 o Jornal O Globo publica matéria com a seguinte chamada: Sete mortos em ataque a ônibus que saiu do Espírito Santo e seguia para São Paulo. ${ }^{86}$ Segundo testemunhas, 30 bandidos armados invadiram o ônibus, assaltaram os passageiros e atearam fogo no veículo. Tal acontecimento serviu de inspiração para duas cenas produzidas para a novela Vidas Opostas (Record, 2007) e Páginas da Vida (Globo, 2006, 2007). Em Páginas da Vida, no capítulo 199

86 Ver: Jornal O Globo, 28/12/06. Disponível em: http://oglobo.globo.com/rio/mat/2006/12/28/287212020.asp. Acesso: 10/02/2010 
exibido em 26/02/2007, a personagem Angélica (Claudia Mauro) morreu carbonizada nos mesmos moldes da tragédia do ônibus incendiado. No final do capítulo em questão, o namorado da de uma das vítimas - a modelo Beatriz Furtado - relata o drama real sofrido por sua namorada:
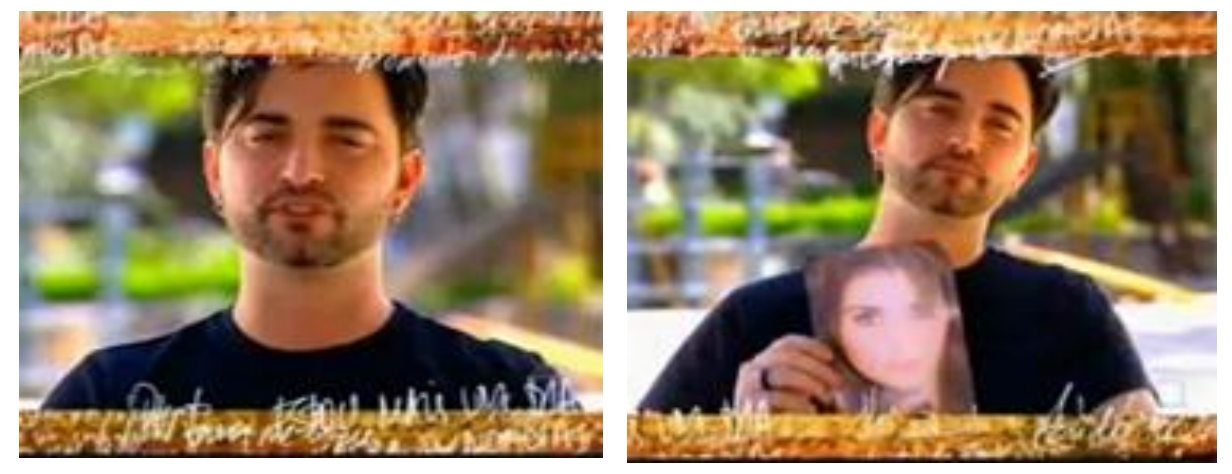

Eu sou namorado da Beatriz Furtado, a modelo que tava no ônibus que foi incendiado no dia 28 de dezembro. A gente já tá junto há oito anos. Colocaram fogo na entrada do ônibus. As pessoas não sabiam como sair do ônibus, pois o ônibus era lacrado porque tinha ar condicionado. Ela conseguiu sair pela janela na hora que a janela estourou com o calor do fogo e, nessa altura do campeonato, ela já tinha se queimado bastante e muita gente, inclusive, não conseguiu sair do ônibus que já tava tomado por fumaça. Quando ela chegou no hospital os médicos disseram que ela tinha trinta por cento de chance de sobrevivência. Ela queimou muito as mãos, queimou um pouco o rosto, queimou bastante as costas. É surreal ouvir ela contando essa história. Parece uma série de terrorismo. É surpreendente saber que isso aconteceu aqui no Brasil. Eu fiquei pasmo com a falta de assistência do Estado, falta de comprometimento da própria empresa de ônibus. Ela me pergunta muito, inclusive, 'e agora, como vai ser sair na rua?'. Ela tá se recuperando, graças a Deus! Acredito que em breve ela vai tá em casa e a gente vai tá se casando em setembro, tendo filhos e realizando tudo o que a gente sempre quis. E acredito que os nossos filhos vão encontrar um Brasil muito mais justo, muito menos violento e com muita paz (mostrando a fotografia da namorada) - Amor, tô com você e eu amo você.

A revista Veja, publicada no dia 14/02/2007, enfocou o bárbaro crime do qual foi vítima o menino João Hélio de 6 anos de idade. Com o título "Sem limites para a barbárie", a matéria enfoca o suplício público de um menino de 6 anos no Rio mostra que o Brasil está na sala de emergência de uma tragédia social em que o bandido decide quem vive e quem morre $^{87}$. No capítulo 200, de Páginas da Vida, que foi ao ar em 27/02/2007, vinte dias após a 
tragédia, os pais de João Hélio encerraram o capítulo daquele dia, conforme transcrevemos abaixo.

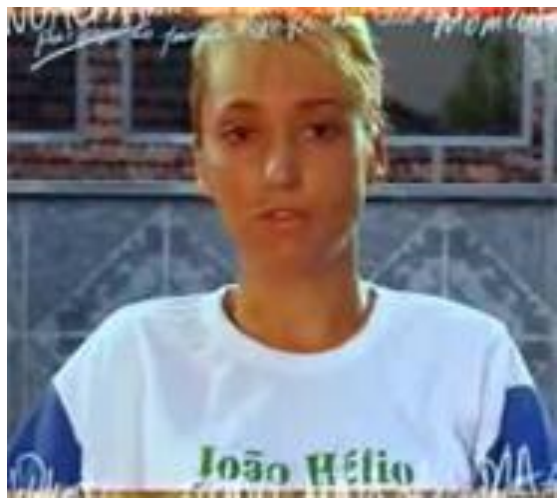

No dia 07 de fevereiro eu fui levar os meus dois filhos pra fazer evangelização como toda quarta-feira. Eu fui sozinha, porque meu marido não podia ir comigo. Na volta, eu fui abordada e nesse assalto arrastaram o meu filho, preso ao cinto de segurança por sete quilômetros. Eu queria ter poderes de super herói mesmo de poder levantar voo e tirar meu filho daquela situação. Eu corri, corri com a minha filha, mas eu sabia que ali o fim dele já tava traçado.

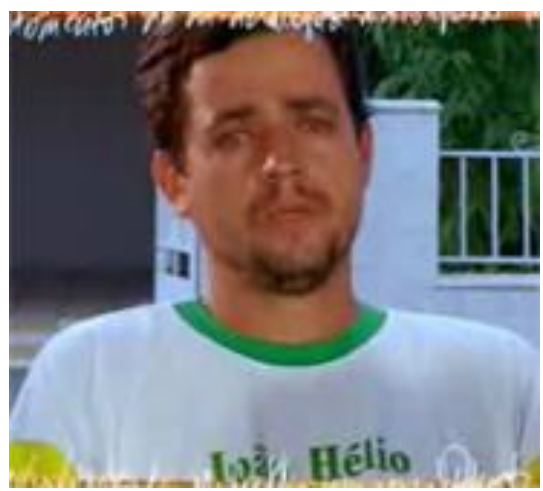

No dia que aconteceu essa brutalidade, durante o dia, foi um dia até atípico, ele fazia futebol de salão e nesse dia eu tive que resolver um problema exatamente do lado do clube. Como eu tava aguardando uma pessoa chegar eu resolvi assistir. Ele marcou um gol durante o jogo, ele fez um gol e até o professor falou que pela primeira vez ele fez um gol durante o jogo, né? E eu tenho certeza que naquele momento que eu vibrei junto com ele, participei. Todo pai que estiver me assistindo agora, vai tá sentindo a minha dor. Como é acompanhar o filho no futebol, vibrar com ele, participar, ser pai acima de tudo. Então esse momento como todos os outros vai ficar marcado pra sempre. 


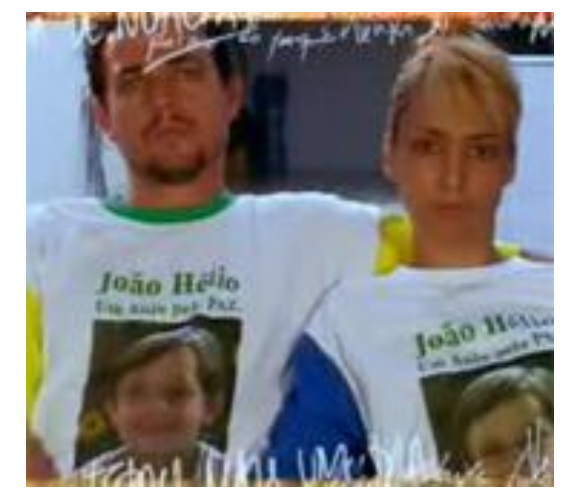

Essa foi a nossa despedida através de um crime brutal. Eu queria saber quantos mais "Joãos" vão precisar ser sacrificados para que o país mude, quantos? Quantos precisam? E aí não vamos fazer nada? Diante de tanta violência...

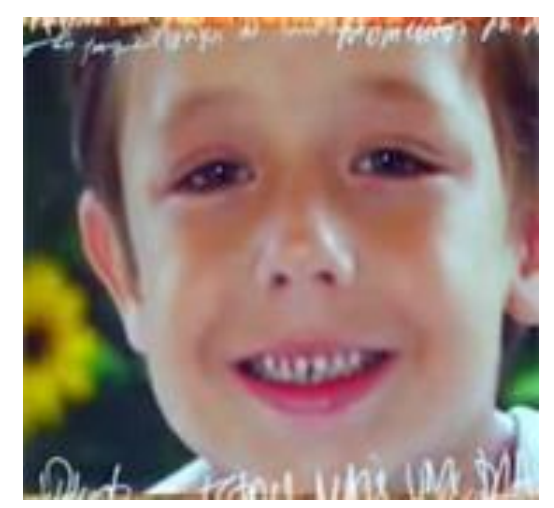

No final do depoimento, há um Insert da foto de João Hélio. Na sequência: vinheta de encerramento com o "sobre crédito" sem som criando um efeito de um minuto de silêncio como nos telejornais. Destacamos que esse acontecimento comoveu todo o país diante de um crime hediondo, conferindo ao fato o caráter espantoso, efêmero e sensacionalista, características tipicas de um clássico fait divers e dos docudramas, conforme tivemos a oportunidade de trabalhar no capítulo 2.

Nesses depoimentos, os fatos em si são tomados como enunciadores reais, além dos próprios entrevistados que, olhando diretamente para câmera, interrompiam a leitura fictivizante da telenovela e estimulavam o espectador a tomar como enunciador real a existência do cameraman. Nessa perspectiva, podemos apontar o autor de telenovela como um âncora do real, na medida em que pauta assuntos, abre espaço para "entrevistas" na forma de 
relato e estimula discussões acerca de temas que atingem diretamente a sociedade brasileira. Esse "âncora" constrói tramas que transitam entre a simulação de fatos baseados na realidade e garantem a autenticidade dos assuntos representados ao citar acontecimentos amplamente noticiados pela imprensa especializada.

\section{5 Docudrama em Viver a Vida}

Em 2009, em Viver a Vida, Manoel Carlos repete a mesma estratégia de inserção de depoimentos de pessoas "reais" no final de cada capítulo, quase que nos mesmos moldes de sua novela anterior, Páginas da Vida, em 2006. É a realidade mais uma vez se misturando com a ficção. Retomando o que seria "a seguir cenas do próximo capítulo", a novela Viver a Vida mostra três quadros em movimento que aparecem simultaneamente na tela com pequenos trechos do que acontecerá no capítulo do dia seguinte. Um “clarão" toma conta da tela anunciando o depoimento do dia. Com o objetivo de compreender melhor essa estrutura de relatos reais que são "enganchados" na ficção, separamos seis desses depoimentos que foram ao ar na semana de 01/02/2010 a 06/02/2010, conforme ilustramos a seguir. Numa leitura mais geral, procuramos identificar elementos em comum em todas essas edições. Notamos, em primeiro lugar, que, independentemente da pessoa que relata seus dramas de vida, a edição desses trechos segue um padrão que prevê a inserção de fotografias em preto em branco no fundo da cena, pequenas frases ou palavras extraídas dos depoimentos que entram e saem em fusão auxiliando a leitura do espectador. São pessoas "reais" e não famosas que, provavelmente, nunca teriam um espaço no horário nobre da televisão identificadas com nome, sobrenome, idade e local onde mora. As temáticas seguem representando a voz de "excluídos" socialmente: são ex-presidiários, negros, portadores de necessidades especiais, entre outros. $\mathrm{Na}$ amostragem que selecionamos, os temas retratados são na ordem: adoção/estupro; assalto/ deficiência física; problemas no parto/lesão cerebral; expresidiário/superação pela leitura; fome/miséria/sucesso pelo esforço pessoal; transplante de pulmão. Em quase todos os depoimentos, as pessoas se emocionam, choram por relembrar de algum acontecimento triste que sofreram ou presenciaram, mas que, de um certo modo, superaram as tragédias e limitações. Nos finais dos depoimentos, as pessoas aparecem necessariamente sorrindo, deixando a mensagem de que o sofrimento faz parte do passado e, como no final de uma novela, tudo acaba sendo resolvido indicando o caminho da felicidade. 
Neste sentido, Fuenzalida afirma que o docudrama:

Dia: $01 / 02 / 2010$

(...) está claramente aparentado com o melodrama da telenovela latinoamericana: situações dramáticas basicamente sobre problemas pessoais gerados em torno da família e do lar; portanto o espaço cenográfico do lar é preponderante. $\mathrm{O}$ relato não tem o ritmo vertiginoso de um seriado de ação cujo herói busca decididamente atingir uma meta épica, é uma narração lenta cujos protagonistas tentam assimilar uma desventura, com fortes emoções envolvidas, e têm grandes incertezas ou obstáculos sobre a forma de resolvêla. A temática do gênero é o reverso da comédia, que alude a erros e desventuras com um tom de alegria e otimismo. (Fuenzalida, 2008, p. 162)

Segunda-feira

Tema: Adoção/estupro

\begin{tabular}{|c|c|c|}
\hline Lettering & Referente & Transcrição do depoimento \\
\hline $\begin{array}{l}\text { Vanessa Lacerda-30 } \\
\text { anos - Rio de } \\
\text { Janeiro. } \\
20 \text { anos } \\
\text { foi atacada por um } \\
\text { homem } \\
\text { desmaiou } \\
\text { sofreu VIOLÊECIA } \\
\text { sexual }\end{array}$ & $\begin{array}{l}\text { Foto da amiga } \\
\text { abraçada com a } \\
\text { Vanessa. } \\
\text { Foto da formatura de } \\
\text { Vanessa. } \\
\text { Foto de Vanessa com } \\
\text { seu marido. } \\
\text { Foto de Vanessa } \\
\text { sorrindo. }\end{array}$ & $\begin{array}{l}\text { Aos } 17 \text { dias de nascida, a minha mãe não } \\
\text { pôde ficar comigo e eu passei a se criada por } \\
\text { uma outra pessoa. Quando eu tinha por volta } \\
\text { de vinte anos, eu tava voltando do trabalho } \\
\text { por volta das dez da noite e eu fui } \\
\text { surpreendida por alguém e era um homem, } \\
\text { ele começou a me bater. Chegou um } \\
\text { momento que eu não tinha mais forças e eu } \\
\text { acabei desmaiando. E quando eu acordei, esse } \\
\text { homem tava em cima de mim, já tinha me } \\
\text { violentado e pretendia me matar e eu falei pra } \\
\text { ele que se ele me deixasse ir, eu já tinha } \\
\text { perdoado e que eu precisava cuidar da minha } \\
\text { mãe que tinha uma pessoa que precisava de } \\
\text { mim. Ele se convenceu. Eu esqueci que eu } \\
\text { era mulher, eu me esqueci... eu tinha medo de } \\
\text { todo mundo e eu me culpava por isso porque } \\
\text { eu achava que poderia ter feito alguma } \\
\text { coisa... e aceitar isso e entender que eu não } \\
\text { era culpada foi o mais difícil. Eu não sabia } \\
\text { como recomeçar mais eu tive a ajuda de uma } \\
\text { grande amiga e ela me fez redescobrir a } \\
\text { mulher que havia em mim. Hoje eu sou } \\
\text { advogada, eu encontrei uma outra pessoa } \\
\text { maravilhosa que é o meu marido. A gente ta } \\
\text { construindo uma família. Eu sigo em frente } \\
\text { porque a vida me deu três provas, desde a } \\
\text { adoção, a não ser contaminada por nenhuma } \\
\text { doença e a ter sobrevivido ao estupro. }\end{array}$ \\
\hline
\end{tabular}


Dia: 02/02/2010

Terça-feira

Tema: Assalto/deficiência física.

\begin{tabular}{|c|c|c|}
\hline Lettering & Referente & Transcrição do depoimento \\
\hline $\begin{array}{l}\text { "viver um dia após o } \\
\text { outro" } \\
\text { Fez natação } \\
\text { mergulho } \\
\text { pinta quadros } \\
\text { maneira de fazer } \\
\text { diferente }\end{array}$ & $\begin{array}{l}\text { Foto de Jefferson com } \\
\text { roupa de mergulho. } \\
\text { Foto (simulação) de } \\
\text { uma rapaz assaltando } \\
\text { o carro. } \\
\text { Foto de Jefferson com } \\
\text { sua mãe. } \\
\text { Foto de Jeferson no } \\
\text { hospital }\end{array}$ & $\begin{array}{l}\text { Eu era mergulhador profissional, trabalhava } \\
\text { com mergulho profundo, tava fazendo um } \\
\text { curso de especialização na época e fui } \\
\text { baleado numa tentativa de assalto quando eu } \\
\text { tinha } 23 \text { anos e era véspera do dia das mães e } \\
\text { infelizmente o presente que a minha mãe } \\
\text { ganhou naquela época foi isso né? Eu lembro } \\
\text { que eu sai do centro cirúrgico quando eu } \\
\text { recobrei a consciência pensando em como } \\
\text { seria a semana seguinte pra eu voltar por } \\
\text { curso. Eu pra não cair nessa depressão, } \\
\text { percebi que a solução é viver um dia após o } \\
\text { outro e eu saí do centro de reabilitação e fui } \\
\text { entrar no esporte. Fui atleta da natação, voltei } \\
\text { a fazer mergulho e hoje eu já estou me } \\
\text { redescobrindo, eu estou pintando quadros, } \\
\text { usando o pincel com o uso da boca. A } \\
\text { deficiência ela não significa o fim, significa } \\
\text { uma maneira de fazer diferente. O carro é } \\
\text { adaptado, eu dirijo dessa forma, eu ando } \\
\text { adaptado, a cadeira é uma adaptação. É claro } \\
\text { que a depressão bate, que a mágoa bate, mas } \\
\text { eu sempre pensei muito claro nisso, já tá } \\
\text { difícil, se eu ficar revoltado vai ficar mais } \\
\text { difícil ainda tanto pra mim, quanto pra quem } \\
\text { me apóia. }\end{array}$ \\
\hline
\end{tabular}


Dia: $03 / 02 / 2010$

Quarta-feira

Tema: Problemas no parto/ lesão cerebral.

\begin{tabular}{|c|c|c|}
\hline Lettering & Referente & Transcrição do depoimento \\
\hline $\begin{array}{l}\text { Eliane Louzada, } 51 \\
\text { anos, Rio de Janeiro } \\
\text { - RJ } \\
\text { O bebê teve } \\
\text { dificuldades para } \\
\text { nascer } \\
\text { asfixia } \\
\text { paralisia cerebral } \\
5 \text { dias no CTI } \\
\text { nunca foi para escola } \\
\text { especial } \\
\text { motora e de escrita }\end{array}$ & $\begin{array}{l}\text { Foto do bebê sorrindo } \\
\text { foto de Eliane, seu } \\
\text { marido e a filha já um } \\
\text { pouco maior. } \\
\text { Foto de crianças } \\
\text { saindo de uma } \\
\text { piscina. }\end{array}$ & $\begin{array}{l}\text { Aos } 29 \text {, eu fui ter a minha primeira filha. } \\
\text { Chegou na hora do parto ela não saia, a } \\
\text { médica insistiu em fazer o parto normal e } \\
\text { acabou que ela nasceu com asfixia, ela tava } \\
\text { com o cordão enrolado e teve uma paralisia } \\
\text { cerebral. Ela ficou cinco dias no CTI, aí ela } \\
\text { teve alta e finamente eu cheguei com o meu } \\
\text { bebê em casa. A neurologista nunca indicou } \\
\text { uma escola especial, ela nunca repetiu ano. A } \\
\text { parte motora e de escrita que era mais } \\
\text { complicada. Ela tinha acho que uns dez anos, } \\
\text { ela tava no clube, na piscina e ela usava bóia, } \\
\text { ainda, porque ela fica insegura na água e aí as } \\
\text { crianças da idade falavam assim "ela é } \\
\text { lesada", aí ela falou, eu me surpreendi, ela } \\
\text { falou: "eu sou lesada, eu tenho uma lesão } \\
\text { cerebral, você não sabe o que é isso não?" } \\
\text { Essa é ela, ela sempre não se esconde. Fez } \\
\text { vestibular e passou. O maior desafio pra mim } \\
\text { é provar que a Thays é uma pessoa capaz e } \\
\text { não aceito de maneira nenhuma que as } \\
\text { pessoas fiquem com pena dela. E essa é a } \\
\text { minha Thays, a minha vitória, a razão da vida } \\
\text { da minha família. (Eliane abraça e dá um } \\
\text { beijo em sua filha). }\end{array}$ \\
\hline
\end{tabular}


Dia: 04/02/2010

Quinta-feira

Tema: Ex-presidiário/encontro com a leitura.

\begin{tabular}{|c|c|c|}
\hline Lettering & Referente & Transcrição do depoimento \\
\hline $\begin{array}{l}\text { Luiz Mendes, } 57 \text { anos, } \\
\text { São Paulo-SP } \\
\text { fugiu de casa } 11 \text { anos } \\
\text { roubar } \\
\text { foi preso } \\
1979 \\
\text { artigo de lei } \\
\text { terminou o } 1^{\circ} \text { e o } 2^{\circ} \\
\text { grau } \\
\text { passou no vestibular } \\
\text { "eu não estava } \\
\text { preparado para } \\
\text { aquilo" } \\
47 \text { dias na rua } \\
\text { preso baleado } \\
\text { queria entender sobre } \\
\text { o passado } \\
\text { futuro } \\
\text { decidiu ser escritor } \\
\text { cumpriu } 31 \text { anos e } 10 \\
\text { meses } \\
\text { livros }\end{array}$ & $\begin{array}{l}\text { Fotos de uma página } \\
\text { manuscrita. }\end{array}$ & $\begin{array}{l}\text { Começo minha vida fugindo de casa aos } 11 \\
\text { anos de idade. Com os meninos na rua eu fui } \\
\text { aprendendo a roubar. Fui preso por assalto, } \\
\text { homicídio.. até que em } 1979 \text { saiu um artigo } \\
\text { de lei dizendo que o preso podia frequentar o } \\
\text { curso superior na rua. Eu comecei a estudar } \\
\text { com um material bastante precário sem uma } \\
\text { orientação, sem nada. Fim de } 81 \text { eu já tinha } \\
\text { eliminado o primeiro e segundo grau num } \\
\text { exame supletivo, daí eu fiz o vestibular ai } \\
\text { então foi uma alegria e tal, até que eu não } \\
\text { aguentei mais, me enrolei todo eu não tava } \\
\text { preparado para aquilo e fugi. Fiquei } 47 \text { dias } \\
\text { na rua, fui preso, baleado e daí comecei a } \\
\text { refletir e nessa reflexão, comecei a entender o } \\
\text { que que se passava comigo, ai minha mãe } \\
\text { vinha me visitar e eu comecei a questioná-la, } \\
\text { como eu era quando criança porque eu não } \\
\text { lembrava mais. Eu comecei a escrever aquilo. } \\
\text { Quiseram publicar. Ai então eu ganho o } \\
\text { futuro, aí comecei a escrever e me decidi por } \\
\text { ser escritor. Eu saí da prisão depois de } \\
\text { cumprir } 31 \text { anos e } 10 \text { meses. O que me salvou } \\
\text { eu digo sempre que foi os livros. Mas não foi } \\
\text { bem a leitura, foram as pessoas que em } \\
\text { trouxeram os livros e me incentivaram a ler a } \\
\text { estudar, sim, essas pessoas são as pessoas que } \\
\text { eu mais quero agradecer e serei eternamente } \\
\text { grato a elas. }\end{array}$ \\
\hline
\end{tabular}


Dia: 06/02/2010

Sexta-feira

Tema: Fome/miséria/sucesso pelo esforço.

\begin{tabular}{|c|c|c|}
\hline Lettering & Referente & Transcrição do depoimento \\
\hline $\begin{array}{l}\text { Heloísa Helena - } \\
\text { "Zica”, } 49 \text { anos, Rio } \\
\text { de Janeiro - RJ } \\
\text { babá } \\
\text { empregada doméstica } \\
\text { faxineira } \\
\text { lavadeira } \\
\text { passou fome } \\
\text { o pai fazia biscates } \\
\text { a mãe era lavadeira } \\
\text { o pai era alcólatra }\end{array}$ & $\begin{array}{l}\text { foto da mãe de } \\
\text { Heloísa } \\
\text { foto de garrafas } \\
\text { Foto de um prato com } \\
\text { feijão com arroz } \\
\text { Foto dos irmãos } \\
\text { Foto de Heloísa aos } \\
21 \text { anos de idade. }\end{array}$ & $\begin{array}{l}\text { Com nove anos de idade, fui babá, } \\
\text { empregada doméstica, faxineira, lavadeira. } \\
\text { Quando eu morava na minha comunidade né? } \\
\text { Morando num barraco, num chão de terra } \\
\text { batida. Era muito difícil porque nós passamos } \\
\text { muita fome. O meu pai era biscateiro, minha } \\
\text { mãe lavadeira pra criar todos os filhos. Meu } \\
\text { irmão areava panela na rua pra receber } \\
\text { moedas pra que a gente pudesse comer } \\
\text { porque meu pai gastava tudo com bebida, } \\
\text { então essas moedinhas serviam pra que pelo } \\
\text { menos a gente tivesse um feijão com arroz. } \\
\text { Ver a minha mãe dividindo um prato de } \\
\text { comida com treze e ela não poder comer, ou a } \\
\text { gente ou almoçava ou jantava. Era muito } \\
\text { difícil dormir com fome. Com } 21 \text { anos de } \\
\text { idade, fui fazer um curso de cabeleireira e, } \\
\text { em casa, eu com uma bacia, colher de pau, eu } \\
\text { misturava matérias primas. } 10 \text { anos depois eu } \\
\text { consegui fazer a formulação certa e eu } \\
\text { consegui registrar esse produto. Abri o meu } \\
\text { primeiro salão. Hoje a gente tem } 10 \text { salões. } \\
\text { Pra chegar até aqui aonde eu estou eu nunca } \\
\text { desisti. Fui adiante, lutei pra isso, por isso } \\
\text { que consegui. }\end{array}$ \\
\hline
\end{tabular}


Dia: $07 / 02 / 2010$

Sábado

Tema: Transplante de pulmão.

\begin{tabular}{|c|c|c|}
\hline Lettering & Referente & Transcrição do depoimento \\
\hline $\begin{array}{l}\text { Kelly Fernandes, } 28 \\
\text { anos, Santo André- } \\
\text { SP } \\
\text { doença pulmonar } \\
14 \text { anos } \\
\text { bronquiectasia } \\
\text { entrou ar na cavidade } \\
\text { pulmonar } \\
30 \text { dias UTI } \\
\text { necessitava de um } \\
\text { transplante pulmonar } \\
\text { máquina de oxigênio } \\
3 \text { anos } \\
17 \% \text { da capacidade } \\
\text { pulmonar } \\
34 \text { kg } \\
\text { “ meu transplante } \\
\text { não podia ser hoje?” }\end{array}$ & $\begin{array}{l}\text { Foto (Raio-X de um } \\
\text { pulmão) } \\
\text { Foto de Kelly na UTI }\end{array}$ & $\begin{array}{l}\text { Eu nasci com uma doença pulmonar e desde } \\
\text { os dois anos de idade e comecei ter sintomas } \\
\text { dessa doença e aos } 14 \text { anos eu descobri parte } \\
\text { de uma doença chamada bronquiectasia e fui } \\
\text { pra UTI drenar um pulmão porque entrou ar } \\
\text { na cavidade. Eu fiquei } 30 \text { dias nessa UTI e a } \\
\text { minha única indicação pra qualidade de vida } \\
\text { era o transplante pulmonar . Nessa época eu } \\
\text { já estava vivendo numa máquina de oxigênio } \\
\text { e fiquei nela por três anos. Só Tinha } 17 \% \text { da } \\
\text { capacidade pulmonar nessa época. Eu só } \\
\text { tinha } 34 \text { kg na época e resolvi a noite passear } \\
\text { pela sala de visita do hospital pra ter um } \\
\text { momento sozinha, então eu olhei pra vidraça } \\
\text { e perguntei assim "meus Deus meu } \\
\text { transplante não podia ser hoje? Não to } \\
\text { aguentando mais" Quando cheguei no quarto } \\
\text { tinha um médico me esperando dizendo que } \\
\text { tinha um órgão pra mim. O meu transplante } \\
\text { começou na madrugada, durou, durou } 15 \\
\text { horas e hoje eu tenho uma vida muito } \\
\text { tranquila, faço tudo, tenho uma vida normal, } \\
\text { então eu só tenho o que agradecer tudo que a } \\
\text { vida tem me proporcionado, todas as alegrias, } \\
\text { e vivo ela intensamente com muito alegria. }\end{array}$ \\
\hline
\end{tabular}


Como esperado, a instituição "família" é destacada como elemento norteador de todos os relatos da amostragem: ("a minha mãe não pôde ficar comigo" ... "que eu precisava cuidar da minha mãe"... “eu encontrei uma outra pessoa maravilhosa que é o meu marido. A gente tá construindo uma família"); ("fui baleado numa tentativa de assalto quando eu tinha 23 anos e era véspera do dia das mães e infelizmente o presente que a minha mãe ganhou naquela época foi isso né?); (e essa é a minha Thays, a minha vitória, a razão da vida da minha família").

Lopes, Borelli e Rezende (2002, p. 141) afirmam que "a família é não só o modelo de assistência da telenovela, como a telenovela é um texto melodramático televisivo para ser lido e fruído de forma coletiva, especificamente em contato com os outros, em grupo, em família".

Evidentemente, por estarem numa estrutura de relato, os discursos são construídos quase que predominantemente em primeira pessoa, constituindo a função emotiva da linguagem: "a chamada função EMOTIVA ou "expressiva", centrada no REMETENTE, visa a uma expressão direta de atitude de quem fala em relação àquilo de que está falando. Tende a suscitar a impressão de uma certa emoção, verdadeira ou simulada" (Jakobson, 2007, p.124).

Defendemos que essas "intervenções" do "real" na telenovela seguem, em seu formato, estruturas típicas de um docudrama, permitindo a operacionalização da leitura docudramentarizante. Vejamos: o melodrama é evidentemente marcado nessas narrativas através do retrato da família, do forte apelo à emoção e dos "dramas da vida". O leitor/espectador toma o próprio depoente como enunciador real: alguém que não faz parte da ficção e manifesta um testemunho de vida, seus sofrimentos e superações. A existência de um cameraman também é um índice de enunciação real, à medida que as pessoas olham diretamente para a câmera e rompem com a convenção da ficção que estabelece que um ator jamais deve olhar para a câmera. A ancoragem do tempo e do espaço serve como referente e, consequentemente, como elemento enunciador do "real". Os letterings anunciam o nome do responsável pelo relato, idade e local onde mora (Vanessa Lacerda - 30 anos - Rio de Janeiro) e o próprio depoente dá conta de situar o "onde" e o "quando" dos fatos: "Aos 17 dias de nascida".... "eu tava voltando do trabalho por volta das dez da noite". Chama a atenção a intensa utilização de fotografias e "retratos" de família como referentes. À medida 
que o relato se constrói, fotografias em preto e branco são inseridas no cenário e pequenos textos extraídos do discurso ajudam o espectador a compreender a informação. “Ao congelar pessoas, coisas ou situações em instantâneos, a fotografia funciona como um repetido testemunho de que o instante já passou, não mais existe, desapareceu para sempre, morreu", afirma Santaella (2001, p. 134). Essa ideia da "morte" de um instante capturado por uma fração de segundo de um tempo e espaço que jamais tornarão a se repetir ainda fica mais evidente nas histórias retratadas nos depoimentos. No caso de Jefferson Maia, que se tornou paraplégico após ser vitimado de um assalto no qual levou vários tiros, a aparição de sua fotografia ainda jovem, esportista, praticando mergulho choca, pois testemunha o retrato de um época que jamais voltará, sobretudo, reforça que sua limitação de mobilidade física é irreversível, sua plena saúde só pode ser vista na fotografia que atesta que um dia foi jovem e com todo o vigor físico. O fato de as fotografias aparecerem em "preto e branco" acarreta a sensação de um passado muito distante que acaba por provocar saudosismo de um tempo que morreu, mas que aparece na forma de signo, de representação num suporte fotoquímico ou digital para permanecer na eternidade. "Ao se fazer presente, todo signo coloca em ausência aquilo que está nele representado. A mera presença do signo cria, por isso mesmo, uma espécie de morte, uma nostalgia do ausente”, continua Santaella (2001, p. 138).

Para Kossoy:

A chamada "fotografia documental" abrange o registro fotográfico sistemático de temas de qualquer natureza captados do real; no entanto, existe, em geral, um interesse específico, uma intenção no registro de algum assunto determinado. É em função disso que surgiu o hábito de se separar ou dividir a fotodocumentação por classes ou categorias de documentação: jornalística, antropológica, etnográfica, social, arquitetônica, urbana, geográfica, tecnológica etc. Essas classificações são, não raro, pouco convincentes, posto que permitem leituras sob diferentes abordagens, de acordo com a formação ou interesse pessoal dos diferentes receptores. Uma única imagem reúne, em seu conteúdo, uma série de elementos icônicos que fornecem informações para diferentes áreas do conhecimento: a fotografia sempre propicia análises e interpretações multidisciplinares. (Kossoy, 2002, p. 51)

Visto pelo lado oposto, embora a máquina fotográfica apreenda um pedaço ou um aspecto do real, é inegável que há uma mediação do olhar do fotógrafo que seleciona, ele mesmo, o que fica em quadro e fora dele. A pessoa fotografada, muitas vezes, perde o caráter espontâneo, posto que faz "poses", se prepara para o ato fotográfico. Em relação aos 
depoimentos de Viver a Vida, raciocínio similar se impõe: como é óbvio, as pessoas que lá estão dando seus depoimentos são previamente orientadas e dirigidas por produtores e diretores que fazem a mediação das gravações. Seguramente, as pessoas estão previamente produzidas no que diz respeito a make-up, figurinos e como se portar diante da câmera. A responsabilidade pela autenticidade dos fatos ali relatados é do depoente, mas a forma e o tempo da narração são determinados pela própria estrutura da telenovela. Dito de outra maneira, há um evidente corte, uma edição intervindo a todo momento nos relatos que devem ser claros, concisos e completos. Em cerca de um minuto, a história de um dilema de vida é apresentada de maneira linear, prevendo o começo, o meio e o fim. São roteiros da vida "real" que parecem seguir convenções de um roteiro de ficção: cada um dos depoimentos da amostragem é possível ser reduzido a uma estrutura de Story-line, na qual toda uma trama pode e deve ser resumida em, no máximo, cinco linhas escritas ou 30 palavras, organizandose em 1.protagonista; 2 situação; 3. conflito; 4. desenvolvimento do conflito e 5. resolução. Nota-se claramente o plot - elemento gerador de conflito - em todos esses relatos.

Conforme nos ensina Rey:

Toda história tem seu núcleo, seu ponto central, donde partem as demais tramas e intrigas. Plot é a ação principal, geradora de conflitos secundários. A diferença entre plot e story-line não é tão sutil como possa parecer. A story-line é o resumo do enredo. Plot é a sua alavanca, o drama-mor. No Romeu e Julieta, o plot é o ódio entre Montecchios e Capuletos. Sem esse plot não existiria a história porque Romeu e Julieta poderiam se amar livremente. Não haveria mortes. É o motor da história, o que origina um conjunto de ações. (Rey, 1997, p. 22)

Tomando como exemplo o depoimento da Vanessa Lacerda, no ar no dia 01/02/10, apontamos o seguinte:

Protagonista: Vanessa Lacerda

Situação: Vanessa volta do trabalho e é surpreendida por um homem.

Conflito: Vanessa é violentada sexualmente pelo homem que quer matá-la;

Desenvolvimento do conflito: Vanessa sobrevive mas se culpa por não ter conseguido fazer nada.

Resolução: Vanessa supera o trauma, torna-se advogada e se casa. 
Adaptando essas informações à estrutura de uma story-line, a história de Vanessa é resumida em poucas linhas:

Vanessa, na volta do trabalho, é surpreendida por um homem que a violenta sexualmente. Ela sobrevive, mas se culpa por não ter reagido. Supera o trauma, torna-se advogada e se casa.

No caso deste depoimento, o plot da história é a violência sexual da qual Vanessa foi vítima. Numa típica história de ficção, o plot é o que move a história para frente. Se o plot é retirado, não há trama, do mesmo modo que, se retiramos a violência sexual da narrativa do depoimento, ele perde todo o sentido.

No segundo depoimento, o plot da história é o assalto no qual Jefferson é baleado. Pensando o relato de Jefferson numa estrutura de story- line, temos o seguinte:

Protagonista: Jefferson Maia

Situação: Jefferson é mergulhador profissional e quer fazer um curso de especialização na área.

Conflito: Jefferson, numa tentativa de assalto, é baleado.

Desenvolvimento do conflito: Jefferson fica com sequelas e perde a mobilidade corporal.

Resolução: Jefferson vira atleta da natação, volta a mergulhar e, hoje, pinta quadros com o auxílio da boca.

Na forma de story-line:

Jefferson, mergulhador profissional, é baleado numa tentativa de assalto. Perde a mobilidade corporal, mas vira atleta da natação, volta a mergulhar e, hoje, pinta quadros com o auxílio da boca.

Nos demais depoimentos, os temas dos relatos também são os "plots" e todas eles terminam com uma mensagem de superação: 


\begin{tabular}{|l|l|l|l|}
\hline Data & Depoente & Plot (conflito) & Resolução \\
\hline 03/02/10 & Eliane Louzada & $\begin{array}{l}\text { Problemas no parto } \\
\text { que gera asfixia no } \\
\text { bebê. }\end{array}$ & $\begin{array}{l}\text { "O maior desafio pra mim é } \\
\text { provar que a Thays é uma } \\
\text { pessoa capaz e não aceito } \\
\text { de maneira nenhuma que as } \\
\text { pessoas fiquem com pena } \\
\text { dela. E essa é a minha } \\
\text { Thays, a minha vitória, a } \\
\text { razão da vida da minha } \\
\text { família." }\end{array}$ \\
\hline 04/02/10 & Luiz Mendes & $\begin{array}{l}\text { Prisão por assalto e } \\
\text { homicídio. }\end{array}$ & $\begin{array}{l}\text { "Eu comecei a escrever } \\
\text { aquilo. Quiseram publicar. } \\
\text { Ai então eu ganho o futuro, } \\
\text { aí comecei a escrever e me } \\
\text { decidi por ser escritor." }\end{array}$ \\
\hline 05/02/10 & Heloísa Helena & $\begin{array}{l}\text { Fome/ extrema } \\
\text { miséria }\end{array}$ & $\begin{array}{l}\text { "10 anos depois eu } \\
\text { consegui fazer a formulação } \\
\text { certa e eu consegui registrar } \\
\text { esse produto. Abri o meu } \\
\text { primeiro salão. Hoje a gente } \\
\text { tem 10 salóes. Pra chegar } \\
\text { até aqui onde eu estou eu } \\
\text { nunca desisti. Fui adiante, } \\
\text { lutei pra isso, por isso que } \\
\text { consegui." }\end{array}$ \\
\hline & Kelly Fernandes & $\begin{array}{l}\text { Necessidade de } \\
\text { transplante de } \\
\text { pulmão }\end{array}$ & $\begin{array}{l}\text { "Hoje eu tenho uma vida } \\
\text { muito tranquila, faço tudo, } \\
\text { tenho uma vida normal, } \\
\text { então eu só tenho que } \\
\text { agradecer tudo que a vida } \\
\text { tem me proporcionado, } \\
\text { todas as alegrias, e vivo ela } \\
\text { intensamente com muito } \\
\text { alegria. “ }\end{array}$ \\
\hline
\end{tabular}

A inserção desses depoimentos nas telenovelas acaba por aproximar a telenovela do docudrama, posto que é perfeitamente possível operar a leitura docudramentarizante: o espectador da telenovela reconhece as pessoas como enunciadores reais, o cameraman, os referentes na forma de fotografia e a ancoragem do tempo e do espaço dos fatos. $\mathrm{O}$ melodrama é facilmente identificado nessas narrativas de relato construídas nos moldes de um roteiro de ficção. Por mais que os autores não tenham escrito o texto desses relatos, eles 
foram trabalhados de modo a deixar claro o principal elemento gerador de conflito (plot) e é desenvolvido na forma de trama, contemplando os dilemas de toda ordem nesses personagens da vida real. Essas produções cumprem as três categorias básicas que caracterizam o docudrama e, nessa perspectiva, pode ser considerado como uma categoria dentro da telenovela, em outros termos: uma meta-categoria dessa forma de teleficção. 


\section{CONCLUSÃO}

A presente pesquisa concentrou esforços em investigar as relações cada vez mais frequentes entre a ficção e realidade na telenovela brasileira. Partiu-se da hipótese de que o atual período de produção do formato encontra-se numa fase que podemos chamar de novelas híbridas. A hibridação representa uma das palavras-chave deste trabalho na medida em que nos permite contemplar a ideia central de que as novelas híbridas são o resultado de uma constante combinação entre a realidade e a ficção, entre o tradicional e o moderno (MartínBarbero, 2004), entre o culto e popular (Garcia Canclini, 2003) e de um encontro cultural de diferentes origens e tradições (Burke, 2003), a exemplo das novelas de Glória Perez que buscam retratar os comportamentos e tradições de outras culturas em O Clone, (Globo, 2001), América (Globo, 2005) e Caminho das Índias (Globo, 2009) e

nessa perspectiva, a ficção televisiva é um elemento decisivo, pois diz respeito ao modo como as indústrias culturais estão reorganizando as identidades coletivas e as formas de diferenciação simbólica, ao produzir novas hibridações que fragilizam as demarcações entre o culto e o popular, $o$ tradicional e o moderno, o próprio e o alheio. (Lopes, 2004, p. 127)

Para propor essa nova periodização, resgatamos na história da telenovela as tendências narrativas do formato identificando as fases pelas quais é possível compreender o fenômeno: 1. As novelas sentimentais (Lopes, 2009), que abarcam as produções em entre 1951 a 1968 e apresentam histórias tradicionais fortemente apoiadas no folhetim clássico, isto é, narrativas simplificadas, com poucos personagens, exóticas, melodramáticas e maniqueístas; 2. As novelas realistas (Ortiz, Borelli e Ortiz Ramos, 1989), produções compreendidas a partir de Beto Rockfeller (Tupi, 1968, 1969) que romperam com a estrutura folhetinesca clássica incluindo nas narrativas expressões coloquiais, gírias, o cotidiano das grandes cidades e é a ocasião em que o anti-herói ocupa o espaço anteriormente preenchido por heróis e vilões tradicionais. Nunca é demais sublinhar que as novelas desse período foram produzidas em um momento histórico fortemente pautado pelas intervenções de um Governo autoritário que impuseram censura parcial ou total a essas obras. Identificamos a ideia de integração como uma palavra de ordem do governo militar, cujos investimentos e ações políticas visavam a integração do imenso território nacional em uma nação e, nessa perspectiva, a televisão desempenhou um papel fundamental para que o objetivo fosse atingido. Em particular, a 
telenovela representou uma estratégia singular nesse processo de integração do país, pois apresentou narrativas que contemplavam o retrato do interior do país ao representar famílias que saiam do interior em busca de melhores condições de vida nos grandes centros urbanos, principalmente Rio de Janeiro e São Paulo. Constatou-se que das 50 novelas (das 21 horas e 22 horas) produzidas nesse período, 15 (30\%) ambientaram as tramas no interior do Brasil. É significativo que das 15 tramas, 13 foram gravadas em cidades fictícias. Talvez esse recurso cenográfico tenha sido utilizado para que os autores conseguissem desenvolver histórias que escapassem da forte censura às produções de televisão da época. Consideramos esse dado muito importante e sugerimos que estudos futuros contemplem o tema telenovela e censura como forma de compreender melhor as produções desse momento; 3. As novelas naturalistas que, a partir do início da década de 90, introduzem no formato ações de merchandising social nas quais os autores buscam intervir em determinados aspectos sociais promovendo campanhas sociais. Algumas dessas ações tornaram-se célebres: como das mães da candelária em Explode Coração (Globo, 1995) momento em que cerca de 100 crianças desaparecidas foram reencontradas; inseminação artificial em Barriga de Aluguel (Globo, 1990) que discutiu os limites éticos, jurídicos e científicos desse tipo de procedimento e doação de órgãos em De Corpo e Alma (Globo, 1992) e Laços de Família (Globo, 2000), com campanhas que estimularam e conscientizaram a população da necessidade desse ato para salvar outras vidas.

Defendemos que a novela $O$ clone (Globo, 2001) marca o início de uma nova periodização - a das novelas híbridas - caracterizada principalmente por evidenciar "o real" de maneira mais intensificada nas tramas ficcionais. Identificamos, a partir dessa obra, uma forte tendência das novelas em extrapolar os limites e fronteiras do território nacional ambientando suas tramas em terras estrangeiras. Como vimos, das 12 novelas híbridas das 21 horas, 8 ou $67 \%$ adotaram esse procedimento (ver tabela, p...) . Notamos, também, que ao contrário das novelas realistas e naturalistas, principalmente das décadas de 70 e 80 , que intercalavam histórias que se desenvolviam entre o campo e as cidades, as novelas híbridas ambientam tramas exclusivamente urbanas e abordam temáticas que envolvem assuntos contemporâneos e tecnológicos. São narrativas mais complexas, na medida em que abordam diversos assuntos e prevêem um grande número de personagens em suas tramas. As histórias fluem de maneira mais rápida em consonância com as características de um mundo globalizado e a acelerado, conforme ilustra Jorge Fernando, diretor de novelas da TV Globo 
em artigo de jornal divulgado pelo Jornal Gazeta do Povo e publicado em 09/09/2007: “Outro dia estava falando sobre a dificuldade do autor de retratar o seu momento. $O$ autor contemporâneo tem milhões de histórias. Tudo fragmentado e frenético (...) Antes as novelas ficavam três meses com o "segredo da carta". Hoje, não pode ter o "segredo do e-mail" nem por um dia”. As novelas tornaram-se mais viajantes (Martín-barbero, 2004) e globalizadas (Ortiz, 2006).

Argumentamos que as novelas contemporâneas se encaminham para um processo de antificção ao apresentar tramas que abordam o "real" de maneira mais explícita. De início, pensávamos que a telenovela se orientava para uma estética próxima dos tradicionais documentários cinematográficos ao colocar pessoas reais (não atores) representando elas mesmas nos depoimentos da novela $O$ Clone, Páginas da Vida e Viver a Vida. Entretanto, como nos ensina Ramos (2008, p. 25): “O documentário, antes de tudo, é definido pela intenção de seu autor de fazer um documentário (intenção social, manifesta na indexação da obra, conforme percebida pelo espectador)." Nessa perspectiva, nenhum autor de telenovela manisfesta a intenção de produzir documentários mas sim ficção que, muitas vezes, se baseia em fatos reais. Na persecução do objetivo de compreender o fenômeno da relação entre a ficção e realidade na telenovela, nos deparamos com o docudrama. Disso resultou a segunda hipótese desta investigação: a de que a telenovela brasileira se aproxima do gênero docudrama ao mesclar elementos da realidade com a ficção. Buscamos fundamentos conceituais do gênero em Rosenthal (1999) e Fuenzalida (2008) e identificamos que a origem do docudrama remota aos dramatized documentaries, espécie de documentários produzidos exclusivamente para a televisão britânica nos anos 60. Outrossim, nos deparamos com uma escassa bibliografia, tanto nacional, quanto internacional, acerca do tema o que conduziu esta pesquisa a investigar não só as origens do gênero como a identificar suas características comuns e seus mecanismos de funcionamento. A partir do estudo de obras audiovisuais consideradas como docudrama por outros investigadores, a exemplo dos filmes JFK (1991, Oliver Stone), A Lista de Schindler (1993, Steven Spilberg) e a produção brasileira de televisão Linha Direta (Globo, 1999 - 2007), buscamos identificar características comuns e constantes nessas obras.

A leitura documentarizante, proposta por Roger Odin (1984), forneceu importante base teórica e metodológica para os caminhos trilhados por esta investigação, isto é, nos estimulou a refletir sobre a estética do documentário cinematográfico e a pensar se seria 
possível propor algo semelhante em relação ao docudrama. De modo similar aos documentários, os docudramas devem estimular o leitor/espectador a reconhecer enunciadores reais em suas diversas manifestações: os fatos históricos e sociais, personagens, o cameraman, responsáveis pela construção do discurso, referentes que podem se manifestar através de imagens de arquivo em movimento ou em forma de fotografia e ancoragem de datas e locais. Por outro lado, os docudramas tendem a transformar os fatos em tramas e sugerir, assim como os tradicionais melodramas, uma moral à história. Dito de outro modo é possível reconhecer nos docudramas "vilões" e "heróis" a serem punidos ou exaltados. Nessa perspectiva, ilustramos essa questão com os docudramas Linha Direta e Por Toda Minha Vida: enquanto o primeiro estampa na tela de tevê a fotografia de criminosos foragidos da justiça, o segundo exalta a trajetória de vida de uma personalidade importante para a história recente da música brasileira. Concluímos que o docudrama é necessariamente um gênero híbrido entre documentário e melodrama, e deve conter características desses dois gêneros de maneira combinada e misturada. Do documentário, o docudrama herdou o compromisso de criar, no discurso, efeitos de realidade através do distanciamento ou objetividade (uso da terceira pessoa do discurso, através de âncoras apresentadores, locução em off ) e referente (uso de fotografias, materiais de arquivo de vídeo etc); e do melodrama, a tendência em imprimir no discurso efeitos de subjetividade, através de dramatizações, forte carga de emoção e do retrato da família. Nessa contraposição entre a objetividade e a subjetividade é que reside uma das principais diferenças entre os gêneros documentário e docudrama: Enquanto para os documentaristas é primordial criar efeitos de realidade através de mecanismos discursivos que promovam uma espécie de efeito do real com graus de objetividade, para o docudrama, ao contrário, torna-se necessário, por vezes, afastar o discurso da objetividade. Em síntese, defendemos que é plausível propor um modo de analisar e pensar mecanismos de funcionamento discursivos do docudrama através da proposta da leitura docudramentarizante ,através da qual argumentamos que podem ser consideradas docudramas obras audiovisuais que contemplem simultaneamente em suas narrativas: enunciadores reais, referentes e dramatizações com forte apelo melodramático.

Concluímos que o docudrama traz em si semelhanças temáticas com os fait divers e pode ser considerado uma versão audiovisual desse gênero que tanto sucesso fez entre os leitores do século XIX. Assim como os fait divers, os docudramas priorizam assuntos efêmeros, espantosos e sensacionalistas. Como nos ensina Barthes (2009), não há fait divers 
sem espanto: “o espanto implica sempre em uma perturbação, uma vez que a nossa civilização, qualquer algures da causa parece situar-se mais ou menos declaradamente à margem da natureza, ou, pelo menos, do natural.” (Barthes, 2009, p. 218) Quer dizer, em um docudrama os temas priorizados serão aqueles que retratem histórias de mistérios, crimes hediondos, grandes tragédias, enfim, assuntos de comoção coletiva e potencialmente capazes de despertar interesses de leitores/espectadores.

Outro aspecto a ser destacado é a desconstrução das narrativas clássicas fortemente apoiadas no folhetim tradicional. Como vimos, houve um período na história da telenovela brasileira em que produções fantasiosas e distantes da realidade imperavam. De outra parte, essas narrativas de ficção seriada foram abandonando a maneira tradicional e passaram a introduzir assuntos e elementos do cotidiano do país conforme demonstramos na periodização trabalhada no início desta investigação. Ao confrontar, num quadrado semiótico, as ideias de bem vs mal, nos deparamos com uma reflexão muito interessante: além das tradicionais oposições entre heróis e vilões, encontramos as relações contraditórias entre anti-heróis e vilões humanizados. Notamos que os atuais protagonistas nas novelas não seguem mais estereótipos tradicionais; são ambíguos e manifestam características próprias de uma pessoa “de verdade". Por outras palavras, são humanos e manifestam comportamentos contraditórios. Sublinhamos a necessidade da investigação da desconstrução do vilão clássico como forma de pesquisar as razões das transformações e do intenso sucesso alcançado por esses personagens nos últimos anos.

Por fim, trabalhamos na hipótese de que as novelas híbridas aproximam-se do gênero docudrama ao representar de forma mais explícita o "real" em suas tramas ficcionais: a presença de enunciadores reais representados por não atores que registram seus depoimentos de superação de vida diante das câmeras; a citação de fatos históricos e sociais (citação do 11 de setembro, por exemplo); uso de fotografias e de imagens em movimento misturadas à ficção; inclusão dos responsáveis pelo discurso (médicos, assistentes sociais, artistas) nas tramas a fim de reforçar o efeito do real e garantir a autenticidade dos assuntos tratados nas ações de merchandising social são alguns argumentos que ajudam a comprovar esta hipótese.

Com essas breves páginas, esperamos ter contribuído para as pesquisas sobre o fenômeno da telenovela no Brasil. Ao chegar nestas últimas palavras, compreendemos, de fato, que toda pesquisa científica implica desafios, aventuras, dúvidas e sacrifícios e os resultados alcançados jamais serão definitivos e sempre irão sugerir novos caminhos e 
provocações. Todo pesquisador deve ser guiado pela curiosidade; provocado por dúvidas e, sobretudo, apaixonado pelo que faz. Esperamos que a paixão pela telenovela - objeto central desta pesquisa - tenha ficado evidente neste trabalho e que as reflexões sobre o docudrama estimulem outros pesquisadores e realizadores do audiovisual a também se apaixonarem pelo gênero e a compreendê-lo melhor. 


\section{REFERÊNCIAS BIBLIOGRÁFICAS}

AUMONT, Jacques. A Estética do filme. Campinas: Papirus, 1995.

BARTHES, Roland. Ensaios Críticos. Lisboa: Edições 70, 2009.

BAUMAN, Zygmunt. Globalização - As consequências humanas. Rio de Janeiro: Jorge Zahar Editor, 1999.

BARROS, Diana Luz Pessoa de. Teoria Semiótica do Texto. São Paulo: Ática, 2000.

BALOGH, Anna Maria. O Discurso Ficcional na TV. São Paulo: Edusp, 2002.

BROOKS, Peter. The Melodramatic Imagination. United States: Yale university Press, 1995.

BULHÕES, Marcelo. A ficção nas mídias - Um curso sobre a narrativa nos meios audiovisuais. São Paulo: Ática, 2009.

BUONANNO, Milly. News-Values and Fiction-Values: News as serial Device and Criteria of Fictionworthiness' in italian television Fiction. European Journal of communication. Londres: Sage, vol 8, pp. 177-202, 1993.

BURKE, Peter. Hibridismo cultural. São Leopoldo: Unisinos, 2003.

CAMPEDELLI, Samira Youssef. A telenovela. São Paulo: Ática, 1985.

CANNITO, Newton. Entre a violência do real e a violência televisiva. Linha Direta e Caso Norte: as possibilidades estéticas do docudrama televisivo. In: Catani, Afrânio Mendes et al. (orgs.). Estudos Socine de Cinema. São Paulo, Panorama, 2003, pp.172-8.

CORNER, John, British TV Dramadocumentary: Origins and Developments. In: ROSENTHAL,Alan. Why Docudrama Fact fiction on film and TV.United States: Suthern Illinois University Press, 1999. p. 35-46.

COSTA, Flávia Cesarino. O Primeiro Cinema. Espetáculo, narração, domesticação. Rio de Janeiro, Azougue, 2005.

CULLER, Jonathan. Sobre a Desconstrução. Rio de Janeiro: Rosa dos Tempos, 1997.

DA-RIN, Silvio. Espelho Partido, tradição e transformação do documentário cinematográfico. Dissertação de mestrado.Rio de Janeiro: ECO.UFRJ, 1995. 
DERRIDA, Jacques. A escritura e a diferença. São Paulo: Perspectiva, 1995.

ECO, Umberto. Sobre os espelhos e outros ensaios. Rio de Janeiro: Nova Fronteira, 1989.

FERNANDES, Ismael. Memória da Telenovela Brasileira. 3. ed. São Paulo: Brasiliense, 1994.

FERRARA, Lucrécia D`Aléssio. Olhar Periférico. São Paulo: Edusp, 1999.

FERREIRA, Mauro. Nossa Senhora das Oito - Janete Clair e a evolução da telenovela no Brasil. Rio de Janeiro: Mauad, 2003.

FIORIN, José Luiz. Elementos de análise do discurso. São Paulo: Contexto, 2009.

FUENZALIDA, Valerio. O Docudrama Televisivo. MATRIZes. Ano 2, $\mathrm{n}^{\mathrm{o}} 1$. Segundo semestre 2008. pp. 159-171.

GARCIA CANCLINI, Néstor. Culturas Híbridas. São Paulo: Edusp, 2003.

GREIMAS, Algirdas Julien \& Coutès, Joseph. Dicionário de semiótica. São Paulo: Cultrix, 1979.

HALL, Stuart. A identidade cultural na pós-modernidade. Rio de Janeiro: DP\&A, 2006.

HAMBURGER, Esther. O Brasil Antenado. A Sociedade da Novela. Rio de Janeiro: Jorge Zahar Editor, 2005.

HEIDEGGER, Martin. Marcas do Caminho. São Paulo: Vozes, 2008.

HOBSBAWN, Eric J. Nações e Nacionalismo desde 1780. São Paulo: Paz e Terra, 2004.

HOFFER, Tom w. NELSON, Richard Alan. Docudrama on America Television. In: ROSENTHAL, Alan (ed). Why Docudrama Fact fiction on film and TV. United States: Suthern Illinois University Press, 1999. p. 64-77.

HUSSERL, Edmund. Crisis de las ciencias europeas y la fenomenologia trascendental. México: Folios Ediciones, 1984.

IANNI, Octávio. Globalização: Novo paradigma das ciências sociais. Estudos Avançados,vol 8, 21, 1994. São Paulo: USP/IEA.

JAGUARIBE, Beatriz. O choque do real. Rio de Janeiro: Rocco, 2007.

JAKOBSON, Roman. Linguística e comunicação. São Paulo: Cultrix, 2007.

KORNIS, Mônica Almeida. Uma História do Brasil Recente nas Minisséries da Rede Globo. Tese de doutorado: ECA-USP, 2000. 
KOSSOY, Boris. Realidades e ficções na trama fotográfica. Cotia: Ateliê Editorial, 2002.

LEJEUNE, Philippe. O Pacto Autobiográfico. Belo Horizonte: UFMG, 2008.

LEUTRAT, Jean-Louis. Uma relação de diversos andares: Cinema \& História. In: Imagens. Cinema 100 anos. Campinas, Editora da Unicamp, 28-33, ago/dez. 1995.

LIPKIN, Steve. Defining Docudrama: In the name of the Father,Schindler`s List, and JFK. In: ROSENTHAL, Alan (ed). Why Docudrama Fact fiction on film and TV. United States: Suthern Illinois University Press, 1999. p. 370-383.

LOPES, Maria Immacolata V., BORELLI, Silvia H.S. e RESENDE, Vera R.. Vivendo com a Telenovela. Mediações, Recepção, Teleficcionalidade. São Paulo: Summus Editorial, 2002

LOPES, Maria Immacolata Vassallo de. Telenovela Brasileira uma narrativa sobre a nação. Comunicação e Educação. São Paulo (26) 17 a 34. jan/abr. 2003.

. Para uma Revisão das identidades coletivas em tempo de Globalização. in: LOPES, Maria Immacolata Vassallo de. (org) Telenovela Internacionalização $e$ Interculturalidade. São Paulo: Edições Loyola, 2004. p. 122 a 137.

Edições Loyola, 2004

(Org). Telenovela: Internacionalização e Interculturalidade. São Paulo:

Telenovela como Recurso Comunicativo. MATRIZes, São Paulo: ECAUSP/Paulus, ano 3, $\mathrm{n}^{\circ}$ 1. agosto/dezembro 2009. p. 21-47.

LOPES, Maria Immacolata Vassallo de e VILCHES, Lorenzo. (orgs). Mercados globais, histórias nacionais. Anuário OBITEL 2008. São Paulo: Globo, 2008.

LOPES, Maria Immacolata V. e OROZCO GÓMEZ, Guillermo (coords). A ficção televisiva em países ibero-americanos: narrativas, formatos e publicidade. Anuário OBITEL 2009. São Paulo: Globo, 2009.

MACHADO, Arlindo. A televisão levada a sério. São Paulo: Senac, 2000.

MARCONDES FILHO, Ciro (org). Dicionário da Comunicação. São Paulo: Paulus, 2009.

MAQUA, Javier. EL Docudrama Fronteras de la ficción. Madri, Edciciones Cátedra, 1992.

MARTÍN- BARBERO, Jesus. Dos Meios às Mediações - Comunicação, cultura e hegemonia. Rio de Janeiro: UFRJ, 2003. 
Viagens da telenovela: dos muitos modos de viajar em, por, desde e com a telenovela. In: LOPES, M.I.V. (Org). Telenovela: Internacionalização e Interculturalidade. São Paulo: Edições Loyola, 2004. p 23-45.

MATOS,Olgária C. F. Contemporaneidades. São Paulo: Lazuli editora: Companhia Editora Nacional, 2009.

MATTELART, Armand \& Michele. O Carnaval das Imagens - A Ficção na TV. São Paulo:Brasiliense, 1989.

MEYER, Marlyse. Folhetim: uma história. São Paulo: Companhia das Letras,1996.

MOISÉS, Massaud. Dicionário de Termos Literários. São Paulo: Cultrix, 2004.

MORIN, Edgar. Cultura de massas no século XX- volume 1: neurose. São Paulo: Forense Universitária, 2009.

MOTTER, Maria Lourdes. Ficção e realidade - A construção do cotidiano na telenovela. São Paulo: Alexa cultural, 2003.

NICHOLS, Bill. Introdução ao documentário. Campinas: Papirus, 2007.

NICOLOSI, Alejandra Pia. Merchandising social na telenovela brasileira. Um diálogo possível entre ficção e realidade em Páginas da vida. Dissertação de Mestrado. São Paulo: ECA-USP, 2009.

ODIN Roger. Film documentaire, lecture documentarisante, in: ODIN, R e LYANT, J.C. (ed): Cinemas et réalites. Saint-Etienne: Universidade de Saint-Etienne, 1984.

ORTIZ, R. BORELLI, S. RAMOS, J.M.O. Telenovela: história e produção. São Paulo: Brasiliense, 1989.

ORTIZ, Renato. Mundialização da Cultura. São Paulo, Brasiliense, 2006. Cultura Brasileira e Identidade Nacional. São Paulo: Brasiliense, 2006.

PERRONE-MOISÉS. Leyla. Do Positivismo à Desconstrução. São Paulo: Edusp, 2003.

PALLOTTINI. Renata. Dramaturgia de televisão. São Paulo: Ed. Moderno, 1998.

PIGNATARI, Décio. Signagem da televisão. São Paulo: Brasiliense, 1984.

RAMOS, Fernão Pessoa. Mas afinal ... O que é mesmo documentário? São Paulo: Senac: 2008. 
RAMOS, Jesus. MARIMÓN, Joan. Diccionario incompleto del guión audiovisual - Estudio, análisis y métodos para conocer el audiovisual em profundidad. Barcelona: Editorial Océano, 2002.

REY, Marcos. O Roteirista Profissional - Televisão e Cinema. São Paulo: Ática, 1997.

ROSENTHAL, Alan. Why Docudrama? Fact-ficton on film and TV. Southern Illinois University Press, 1999.

SADEK, José Roberto. Telenovela: um olhar do cinema. São Paulo; Summus Editorial, 2008.

SANTAELLA, Lucia. WINFRED, Noth. Imagem- Cognição, semiótica, mídia. São Paulo: Iluminuras, 2001.

SANTOS, Alexandre Tadeu. Telenovela ontem e hoje: Uma clonagem do folhetim clássico ou a renovação do modelo tradicional? Dissertação de Mestrado. Curitiba: Universidade Tuiuti do Paraná, 2003.

SCHIAVO, Márcio. Merchandising social: uma estratégia de sócio-educação para grandes audiências. Tese de livre docência. Universidade Gama Filho. Rio de Janeiro, 1995.

STRAUBHAAR, Joseph. As múltiplas proximidades das telenovelas e das audiências. In: LOPES, M.I.V. (Org). Telenovela: Internacionalização e Interculturalidade. São Paulo: Edições Loyola, 2004. p 74-110.

TEMER, Ana Carolina Rocha Pessoa. TONDATO, Márcia Perin. A televisão em busca da interatividade - uma análise dos gêneros não-ficcionais. Brasília: Cia das Musas, 2009.

THOMASSEAU, Jean-Marie. O Melodrama. São Paulo, Perspectiva, 2005.

WOLF, Mauro. Teorias das Comunicações de massa. São Paulo: Martins Fontes, 2003.

VOLLI, Ugo. Manual de Semiótica. São Paulo: Edições Loyola, 2007.

VILCHES, Lorenzo (comp.). Culturas Y mercados de la ficción televisiva em iberoamérica. Anuário OBITEL 2007: Gedisa Editorial, Barcelona, 2007.

XAVIER, Ismail . O olhar e a voz. A narração multifocal do cinema e a cifra da história em São Bernardo. Literatura e Sociedade. Revista de Teoria Literária e Literatura Comparada. São Paulo, 1997. p. 125 - 152. 


\section{WEBGRAFIA}

DEJAVITE, Fabia Angélica. O poder do fait divers no jornalismo: humor, espetáculo e emoção.

XXIV Congresso Brasileiro de Ciências da Comunicação. Intercom, Campo Grande-MS, 2001. Link: http://www.intercom.org.br/papers/nacionais/2001/papers/NP2DEJAVITE.PDF

DION, Sylvie. O Fait divers como gênero narrativo. Revista letras n. 34, Literatura, outras artes \& Cultura das mídias. Universidade Federal do Rio Grande, 2007. p. 123-131. Link: http://w3.ufsm.br/revistaletras/artigos_r34/revista34_8.pdf

REZENDE, Guilherme Jorge de. O discurso jornalístico e o discurso ficcional na televisão brasileira. Rio de Janeiro: XXVIII Congresso Intercom, 2005. Link: http://galaxy.intercom.org.br:8180/dspace/bitstream/1904/16818/1/R1957-1.pdf

TRINDADE, Eneus. Merchandising em telenovela: a estrutura de um discurso para o consumo. In: Congresso Brasileiro de Comunicação, 1, 1999. Rio de Janeiro. Anais. Rio de Janeiro: Intercom,1999.

Link: http://www.portal-rp.com.br/bibliotecavirtual/outrasareas/publicidadeepropaganda

\section{ENDEREÇOS ELETRÔNICOS}

Memória Globo. Disponível em: http://memoriaglobo.globo.com. Último acesso em: $\underline{24 / 10 / 2010 .}$

Programa Linha Direta: Disponível em: www.globo.com/linhadireta. Último acesso em: 24/10/2007.

Manchetes do jornal Agora, disponível em http://www.agora.uol.com.br/ Acesso em: 07/01/2010.

TV inglesa faz docudrama sobre Jean Charles. Disponível em: http://oglobo.globo.com/cultura/kogut/posts/2008/12/19/tv-inglesa-faz-docudrama-sobre-jeancharles-148315.asp, Acesso em: 14/03/2010.

Sem novidades, o documentário sobre voo 1907 opta pelo didatismo. Disponível em: http://www1.folha.uol.com.br/folha/ilustrada/ult90u300784.shtml, Acesso em: 11/01/2010.

Vilão bom é vilão morto. Disponível em: http://puc-riodigital.com.puc-rio.br/media/1\%20\%20vil\%C3\%A3o\%20bom\%20\%C3\%A9\%20vil\%C3\%A30\%20morto.pdf Acesso em: $23 / 01 / 2010$. 
Sete mortos em ataque a ônibus que saiu do Espírito Santo e seguia para São Paulo. Disponível em: http://oglobo.globo.com/rio/mat/2006/12/28/287212020.asp. Acesso em: 10/02/2010.

Sem limites para a barbárie. Disponível em: http://veja.abril.com.br/140207/p_046.shtml Acesso em: 09/02/2010.

Tragédia merece tom folhetinesco. Folha de São Paulo, 10 mar., 1996. Disponível em: http://www1.folha.uol.com.br/fsp/1996/3/10/tv folha/2.html, Acesso em: 11/01/2010.

A novela faz jornalismo. Mulheres Apaixonadas falou da violência do Rio numa cena gravada 24 horas depois dos fatos. Disponível em:

http://revistaepoca.globo.com/Revista/Epoca/0,,EMI35889-15220,00-

a+novela+faz+jornalismo.html. Acesso em: 05/02/2010.

Glória Perez será homenageada por merchandising social em novela. Disponível em: http://natelinha.uol.com.br/2009/08/21/not_24780.php Acesso em: 21/08/2009.

\section{ARTIGOS DE JORNAL}

Dos Jornais para os folhetins - autores se inspiram em fatos reais para a elaboração das tramas na teledramaturgia. Gazeta do Povo, Curitiba, 7 out. 2007. Revista da TV, p.3.

Corações Suburbanos. Gazeta do Povo, Curitiba, 9 set. 2007.Revista da TV, p.4.

\section{CORPUS AUDIOVISUAL ANALISADO}

\section{PROGRAMAS DE TELEVISÃO}

A maldição do Edifício Joelma. Linha Direta. Rio de Janeiro: Globo. 30 de junho de 2005. Programa de TV.

A tragédia do voo 1907. Acidentes aéreos. São Paulo: Discovery Channel, 10 de junho de 2007. Programa de TV.

Especial Mamonas Assassinas. Por Toda Minha Vida. Rio de Janeiro: Globo, 10 de julho de 2008. Programa de TV.

Fantástico. Rio de Janeiro: Globo, 08 e 15 de novembro de 2009. Programa de TV.

Linha Direta. Direção: Milton Abirached. Rio de Janeiro: Globo, de 29 de março de 1990 a 24 de junho de 1990 e de 27 de maio de 1999 a 01 de fevereiro de 2008. Programa de TV. 
Por Toda Minha Vida. Direção: Ricardo Waddington. 11 programas. Rio de Janeiro: Globo, de 28 de dezembro de 2006 a 03 de dezembro de 2009. Programa de TV.

América. Direção: Marcos Schechtman. 203 capítulos. Rio de Janeiro: Globo, de 14 de março de 2005 a 05 de novembro de 2005. Telenovela.

O Clone. Direção: Jayme Monjardim. 221 capítulos. Rio de Janeiro: Globo, de 01 de outubro de 2001 a 15 de junho de 2002. Telenovela.

Páginas da Vida. Direção: Jayme Monjardim. 203 capítulos. Rio de Janeiro: Globo, de 10 de julho de 2006 a 02 de março de 2007. Telenovela.

Caminho das Índias. Direção: Marcos Schechtman. 203 capítulos. Rio de Janeiro: Globo, de 19 de janeiro de 2009 a 12 de setembro de 2009. Telenovela.

Viver a Vida. Direção: Jayme Monjardim. 219 capítulos. Rio de Janeiro: Globo, de 14 de setembro de 2009 a 16 de maio de 2010. Telenovela.

\section{FILMES}

A Lista de Schindler, Steven Spilberg, 1993, Estados Unidos.

Boa Noite e Boa Sorte, George Clooney, 2005, Estados Unidos.

Bobby - 22 Destinos. 1 Momento da História que Ninguém Vai Esquecer, Emilio Estevez, 2006, Estados Unidos.

In the Name of the Father, Jim Sheridan, 1993, Irlanda, Grã Bretanha, Estados Unidos.

Jean Charles, Henrique Goldman, 2008, Brasil.

JFK , Oliver Stone, 1991, Estados Unidos.

Lula, o Filho do Brasil, Fábio Barreto, 2010, Brasil.

Nixon, Oliver Stone, 1995, Estados Unidos.

Última Parada Ônibus 174, Bruno Barreto, 2008, Brasil.

Voo United 93, Paul Greengrass, 2006, Estados Unidos. 
ANEXO A - Transcrição da Palestra proferida por Glória Perez no I Encontro Nacional Obitel em São Paulo, 28 nov. 2007 
Transcrição da palestra proferida por Glória Perez no I Encontro Nacional OBITEL Observatorio Iberoamericano de la ficción televisiva - "A Pesquisa da Ficção Televisiva no Brasil”, organizado pelo Centro de Estudos de Telenovela - CTVN - da Escola de Comunicações e Artes da Universidade de São Paulo e Globo Universidade, realizado nos dias 26, 27 e 28 de novembro de 2007, sob a coordenação da prof. Dra. Maria Immacolata Vassallo de Lopes.

Immacolata: Bom dia, bom dia, amigos, colegas, noveleiros. Estamos começando agora o terceiro dia do $1^{\circ}$ Encontro Nacional Obitel Globo. Como vocês sabem, muito esperada a apresentação da nossa Glória Perez. Essa parte da manhã será tomada pela apresentação dela, ela fará uma introdução depois abre para pergunta e para debates. Primeiro agradecer a sua presença de você ter aceito o convite de estar aqui conosco. A gente fala que você é objeto de estudo presente. Nossa bibliografia, de fato, superlativos. Ela dispensa apresentação, mas como o dever exige do nosso ritual acadêmico quero fazer uma pequena apresentação da Gloria Perez. Formada em história pela Universidade Federal do Rio de Janeiro estreou na televisão em 1979 ao escrever a sinopse para um episódio do seriado Malu mulher, produzido pela TV Globo. Esse episódio não chegou a ser gravado, mas, anos depois, chamou a atenção de Janete Clair, que convidou Gloria Perez para trabalhar como sua assistente na novela $E u$ prometo em 1983. Em 1984 dividiu com Aguinaldo Silva a autoria de Partido Alto (1984), cuja trama, ambientada no Rio de Janeiro, girava em torno de personagens femininos que moravam na zona sul e no subúrbio carioca do Encantado. Contratada pela Rede Manchete, escreveu a novela Carmem em 1987, outro trabalho cuja trama era ambientada no Rio de Janeiro e teve a direção geral de José Wilker. De volta à TV Globo, em 1990, Gloria escreveu sua primeira minissérie Desejo que contava a história de Anna de Assis e o triângulo amoroso que protagonizou com seu marido, o escritor Euclides da Cunha, e o jovem Dilermando de Assis. Em seguida, ainda em 1990, a autora escreveu sua primeira novela sozinha, Barriga de aluguel. Em sequencia, escreve De Corpo e Alma, 1992, sua primeira novela das oito. Explode coração em 1995, a minissérie Hilda Furacão em 1998, ainda em 1998, a autora escreveu alguns episódios do seriado Mulher. Em 2001, escreveu um dos maiores sucessos da teledramaturgia brasileira, a novela $O$ Clone. A novela abordava questões relacionadas à clonagem, islamismo e dependência química e consagrou a nossa autora que foi homenageada 
pela Associação Brasileira de Alcoolismo e Drogas e recebeu o prêmio Personalidade do Ano de 2002, conferido pelo Conselho Estadual Antidrogas juntamente com o diretor da novela, Jayme Monjardim. Ela também foi premiada pelos principais órgãos norte-americanos de combate ao tráfico de drogas pela campanha realizada em O Clone. Em 2005 escreveu América onde abordou questões super atuais como a imigração ilegal, o homossexualismo, a cleptomania, entre outros. E recentemente escreveu a minissérie Amazônia - De Galvez a Chico Mendes nesse ano de 2007 no qual contou a história da conquista do Acre e da região Amazônica em 100 anos da história recente brasileira.

Eu acho que isso dá um pouquinho do percurso da Gloria Perez como uma das mais brilhantes e destacadas autora das telenovelas brasileiras e quero dizer que ela é a única mulher autora desse primeiro nível de autores atualmente em atuação na televisão brasileira. Então passamos a Glória, a palavra, e somos todos ouvidos. Muito obrigada novamente pela sua participação.

Glória Perez: Obrigada eu quero dizer, antes de mais nada, que eu fico muito feliz de estar aqui com vocês e de saber que existe toda uma preocupação acadêmica um interesse acadêmico a respeito das telenovelas brasileiras. Eu gostaria de ficar em pé, eu me sinto mais a vontade falando andando, tudo bem né? Fica mais intimo, mas eu escrevo em pé também. Então eu acho que, lamento não ter podido estar aqui os três dias ouvindo as reflexões que vocês fazem sobre o nosso trabalho. Eu acho para falar sobre o que é o nosso trabalho eu teria de começar falando da minha trajetória individual porque eu acho que cada um de nós traz para qualquer ramo de trabalho que se dedique essa primeira janela onde a gente olhou o mundo, que é a nossa origem, o nosso trajeto. Isso que vai dar aquela feição particular. Que cada um vai dar ao trabalho que nos fazemos qualquer que seja a nossa área de atuação. Isso vai ter um importância mais tarde até na maneira como eu faço as minhas história. Eu vim de um lugar muito longe, lá dos confins da Amazônia do Acre, e nesse lugar na época em que eu vivi lá, até uns 16 anos depois eu vi para cá para estudar; era um lugar completamente isolado do resto do país, um lugar onde o país não chegava, as notícias por exemplo, revistas, jornais chegavam lá seis meses depois. Então o que acontecia no país não interessava para gente porque não tocava a nossa vida. Você tinha o único elemento que te fazia compartilhar com o resto do país, fazer parte do resto do país que eram as novelas do 
rádio, você escutava as novelas de rádio e sabia que em outros lugares do país as pessoas também estavam também acompanhando os capítulos do Direito de Nascer das outras novelas que na época fizeram sucesso. Eu penso que a televisão pegou parte a diante disso porque as novelas da televisão fizeram com que as sociedades que compunham o nosso país que são tão distantes uma da outra, diferenciadas culturalmente elas se vem não mais compartilhando de uma história, mas retratadas elas começas a poder levar para o resto do país como elas são que tradição elas têm e isso tem uma grande importância em um país como nosso. Então eu acho que para a gente entender a importância da novela no Brasil ou em qualquer outro lugar tem de entender o que ela significa para o país: se ela é apenas entretenimento, o que basicamente qualquer novela é, se é através do entretenimento que ela vai poder cumprir outras funções, se ao deixar de lado a ideia do entretenimento ela já não cumprirá essas outras funções. Mas eu acho entre nós ela tem uma importância maior que nos outros países por coisas que nós já vamos especificar mas isso fez com que eu me encanta-se por ela.

Eu nunca tinha assistido um novela inteira quando eu comecei a fazer novela, na verdade eu queria fazer especial, queria fazer cinema. Eu não assistia novela não por preconceito, por que sempre fui apaixonada pelo veículo televisão, pelo alcance que veículo tinha mas eu fazia faculdade de manhã trabalhava a tarde e fazia outra faculdade a noite. Eu não podia assistir às novelas. Mas escrevi Malu Mulher, ai tenho de fazer uma correção Immacolata, não foi a pedido da casa eu escrevi na minha conta porque era um programa na época que fazia muito sucesso, falava sobre mulher, e eu escrevi aquele Malu Mulher para poder mostrar para alguém que eu sabia fazer aquilo, mas ninguém leu. Porque é difícil vocês sabem o começo é difícil a gente mostra o trabalho e ninguém acredita porque eles recebem 50, 70 scripts. Ai eu tive o fator sorte, eu estava uma vez almoçando num lugar onde e estava a nora da Janete Clair e ela estava comentando que a Janete estava doente e pela primeira vez ia aceitar uma colaboração e já tinha recusado todos os que a Globo tinha mandando, o eu disse que eu fiz o Malu Mulher eu tenho um script será que ela leria? A moça disse me traga que eu vou levar; eu fui em casa peguei o script e a Janete leu enquanto a nora tomava um cafezinho e então ela perguntou para mim você sabe fazer isso, a Janete, e eu pensei comigo nunca mais uma Janete Clair vai fazer essa pergunta. Eu respondi: eu sei. Ai ela me deu uma história e disse vamos ver como você se sai agora, desenvolvendo uma ideia minha. E ai ela me deu uma história quer era de meia página absolutamente folhetinesca, era uma espinha dorsal do que 
poderia ser uma novela ou uma coisa assim em linhas muito gerais era a história de uma pobre babá que trabalhava em uma casa e ficou grávida do filho do patrão e o patrão a expulsou de casa e como a Janete era muito imaginativa e isso e muito bacana e essencial ao folhetim; ela criou a filha sozinha como babá e mas cinco e dez anos depois aquela pessoa que não sabia assinar o nome se transformou na maior autoridade na América Latina. O sogro aquele que e expulsou de casa ficou doente e a babá o salvou. Então nessa reconciliação, ai todo se reconciliam, o pai reconhece a filha o mocinho casa com a mocinha, eu olhei aquilo e confesso para vocês que quando li me apavorou. Eu falei meu Deus o que é isso, ai pera lá vou pensar, isso é um folhetim do século XIX é obvio que há um pouco de Balzac há um intuito e mas o folhetim e isso né? Tem regras, eu comecei a pensar nas regras do folhetim, eu já tinha lido na literatura do século XIX também tinha prestado a atenção nas características que fazem com que um escritor escreva para o folhetim. Por exemplo uma cena que me impressionava em Balzac que eu sempre me refiro a ela por que é um exemplo de um escritor que sabe que está fazendo folhetim. A mulher de 30, por exemplo, ele faz uma aquelas reflexões maravilhosa sobre as mulheres, sobre a união das mulheres, sobre o casamento, mas ele esta escrevendo um folhetim esta escrevendo para o jornal que vender no dia seguinte, então o que ele faz? De repente aquele mocinha é raptada por piratas e o pai que esta andando no mar é atacado por piratas e quando ele é posto no barco dos raptores a filha dele tinha se transformado na rainha dos piratas. Parece um desvio, é um desvio enorme do que ele estava fazendo, mas isso é a regra do folhetim, o sensacional tem de estar acima da coerência, no folhetim é isso, criticar isso como eu vejo muitos críticos de telenovela fazer é criticar o soneto porque tem rima. Isso faz parte do folhetim é inerente ao folhetim, o escritor sabe que está fazendo essa concessão é a forma de contar . Bom, então eu pensei outra coisa que eu pensei, a minha terra, por exemplo, como eu expliquei para vocês que era uma terra muito distante, muito isolada, é uma terra onde você exercita muito a imaginação por causa da passividade porque você tinha de imaginar como era o mundo, você tinha de imaginar como era uma televisão, que já tinha aqui mas não tinha lá, e você via o desenho na revista, você via a descrição das coisas que existia nos outros lugares e você imaginava o resto do mundo, porque você não tinha acesso ao resto do mundo. Então um trabalho da imaginação, ao mesmo tempo era um lugar como era um lugar da aventura e um lugar muito recente também, era um lugar onde as pessoas tinham medo e todas as pessoas tinham histórias em comum. Então o que eu quero dizer, essas coisas que fazem parte do folhetim como exceção, pais que 
não tem filhos, pessoas que se reencontram depois de trinta anos, lá era lugar comum. .. Eram as coisas que estavam a sua volta, não era nada a desnatural essas coisas porque todas essas pessoas tinham essas histórias, todos tinham vindo de longe, todos tinham deixado alguém, todos tinham uma ideia de se reencontrar um dia com um irmão, com um filho, ou descobriam um filho que não sabiam que tinham, enfim, isso era corriqueiro, não era exceção era regra. $\mathrm{E}$ uma outra coisa que eu me lembrei, eu me lembrei dessa vivências e me lembrei também do cordel, eu fiz uma outra associação que não sei se as outras pessoas fazem mas para mim foi importante na hora que eu tive de desenvolver nessa história da Janete pensar nisso. No Acre por exemplo aos domingos aqueles cantadores de cordel cantavam no mercado e gente era criança ia lá assistir e as historias eram como histórias do folhetim eram histórias de vida, eram histórias de percurso de vida, pessoas que subiam e que caiam e que subiam de novo histórias de desencontros e pensando em tudo isso eu consegui fazer. Então comecei uma carreira e me apaixonei pelas novelas mas achei que ia fazer essa e depois conseguiria ir para onde eu queria para especiais, para cinema e outras coisas, mas me apaixonei pelas novelas porque a pratica, essa pratica me deu a dimensão do quanto a novela é importante neste país. Eu percebi, por exemplo, que nos fazíamos o romance, a ópera, o teatro de uma população que não tinha acesso a nada para começar ou porque era analfabeta ou porque não tinha dinheiro para pagar o cinema, não tinha nenhuma outra diversão. Então você levando para essas pessoas a fantasia você era a diversão possível e ao mesmo tempo você podia fazer isso introduzindo temas que podiam ser debatidos e percebidos de outra maneira, o que eu quero dizer com isso: o folhetim, em regra, porque ele se dirige a emoção? Porque a emoção une, se o autor fizer a pessoa se emocionar em um veículo como a tevê da mesma forma como os jornais os primeiros folhetins, ele se dirigiu a várias classes, o jornal queria que tanto empregado lê-se quanto que padrão lê-se o jornal do século XIX. Da mesma forma nos queremos que toda uma sociedade nos assista, quando você se dirige ao intelecto quando a tua mensagem entra pelo intelectual você diferencia algumas pessoas vão gostar e outras não vão entender mas quando você vai pelo emocional você une por isso que o folhetim busca essa sempre essa aproximação, essa porta de entrada porque essa porta de entrada é capaz de atingir os mais diferentes níveis culturais. O que eu busco fazer no meu trabalho abrir porta de reflexão para perceba e queira refletir sobre aquele assunto e se você não quiser e não compreender do que se trata você curte o folhetim. Isso te da à oportunidade de popularizar temas, isso sempre me preocupa, que ficam sempre restritos a debates acadêmicos é isso que 
eu tenho feito ao logo do meu trabalho, não só procurar dar voz a quem não tem focalizando grupos minoritários ou que sejam vítimas de preconceitos e não abrindo a novela pra que outras pessoas falem deles mas dando voz a eles para que eles falem deles próprios. Como no caso dos dependentes químicos que até então eu só tinha ouvido falar os relatos de delegados, psicólogos mas nunca deles, a voz deles, então é essa voz que eu vou buscar. Os ciganos, por exemplo, de Explode Coração, o que o cigano sente? como o cigano vive esse preconceito de que todo cigano é ladrão, de quem tem de ter medo do cigano quando ele chega perto que ele vai roubar alguma coisa. Como ele vive isso? O grupo fala e isso é muito importante e procuro abrir esse espaço. Tem um tema que é muito recorrente para mim, eu vou acabar isso e vou falar como é processo de trabalho, tem um tema que eu sempre busco que são as inovações tecnológicas e inovações da medicina porque eu acho que a gente está vivendo uma época , o final do século passado começo desse, uma grande revolução cada técnica nova que é introduzida modifica o cotidiano das pessoas, mesmo que as pessoas não percebam isso. Essa é a proposta de reflexão que eu incluo nos meus trabalhos que algumas pessoas podem captar, é um convite para pensar sobre o assunto. Como a gente vive experiências hoje criadas por essas inovações tecnológicas sem nenhuma referencia do passado, que nenhuma geração viveu antes que a nossa. Eu vou dar um exemplo, Barriga de Aluguel nunca no mundo desde que o mundo e mundo questionou o que era mãe porque mãe para todos os povos desde a época das cavernas era que a mãe era a mulher que carrega na barriga de repente a possibilidade de fazer a barriga de aluguel reverte isso. Como a pessoa vive isso é se sentir mãe? Como é carregar uma barriga ter um parto como é carregar uma barriga desvincular isso da ideia de que eu sou a mãe? É uma experiência completamente nova nenhuma geração anterior a nossa viveu isso. Como é esse choque do cotidiano do homem moderno diante dessas modificações trazidas por essas inovações. Essa é a parte da história onde eu faço o convite vamos refletir sobre isso porque a gente só escreve sobre aquilo que interessa escrever é uma forma de refletir sobre um assunto e é um convite para refletir junto. Agora se você não quiser discutir isso você vai acompanhar apenas o folhetim, ou seja, a história que vem lá de Salomão: duas mães disputando uma criança e se você quiser vai atentar para o outro aspecto esse outro convite que é pensar sobre um assunto.

A novela tem essa capacidade de jogar na mesa um assunto abrir uma discussão nacional o que é um outro fator de integração nacional e de união. Não só retratar, mas você fazer com que todo país discuta seja um tema como esse que eu disse, ou seja, quem é que 
vai ficar com o mocinho ou quem vai ficar com o filho há um integração nisso.Eu vou parar essa parte da minha trajetória e vou falar do nosso processo trabalho porque eu acho mais interessante é escutar de vocês de onde que vem às curiosidades o que vocês queriam saber.

O processo de trabalho de um escritor é o seguinte: quando você tem que fazer uma novela de fazer uma novela eu por exemplo escolho um tema que me interessa você tem pela frente duzentos e tantos capítulos são 32 paginas por dia que você tem de entregar toda semana você tem de entregar 6 capítulos cada um deles com 32 paginas, imagine fazer isso de um assunto que você não tenha nenhum interesse, não pode. Eu acho que você tem de ser apaixonado por aquilo que faz porque se você não for você não consegue fazer vai falar de fala tão burocrática isso passa na tela, passo o entusiasmo a paixão que você deposita é visível por mais que você esconda o publico vai sentir é o dar colorido ou não dar. Bom então você é chamado para fazer uma novela é como se fosse uma arquitetura eu vou pensar uma história eu penso sempre primeiro num tema, isso meu caminho não é o único caminho há autores que pensam primeiro na trama e a novela pode ser um sucesso extraordinário do mesmo jeito é um caminho muito pessoal vai da porta de entrada. A minha é o tema porque eu gosto de escolher um tema sobre o qual eu quero refletir e ai eu vou dramatizar esse tema é uma arquitetura você tem de fazer uma história que tenha fôlego para durar duzentos e tantos capítulos. É claro que você não sabe na hora que você escreve uma sinopse como que aquilo vai se desenvolver completamente você sabe em grandes linhas, não precisa marcar pequenas linhas e mesmo essas grandes linhas podem se transformadas porque uma coisa é a sinopse é quando você descreve uma personagem outra coisa é quando você parte para o segundo momento que é incorporar essa personagem, que é falar como ela, sentir como ela viver como ela e a personagem ai ganha uma certa independência de você e ela passa ser uma pessoa a parte de você para você mesma. Então uma personagem as vezes ela nos assusta porque as vezes você quer que ela faça uma coisa mas ela faz outra ela pede outra e ela sempre ganha de você porque se você não fizer aquilo você não pode continuar; chega um momento que primeiro você a cria e depois você tem de seguir a sua criatura porque escrever 30 personagens ao mesmo tempo... Mas se você não se entregar inteiramente a essa personagem a ponto de deixar que ela te carregue de uma certa forma, você não vai conseguir fazer porque você vai fazer uma personagem curta que fala de um jeito você tem de se colocar naquele ponto de vista e ai você vai fazer uma personagem que enxerga um mundo menor que tem uma outra concepção que está numa outra janela você tem de se mudar inteiro porque 
senão você vai falar criticando vai falar como alguém que está vendo de fora aquela personagem você não está entrando na pele dela. Eu acho que uma das principais característica do escritor para ele escrever qualquer coisa é gostar de gente, a ponto de querer se meter na pele dos outros e ser tão curioso da espécie humana e quer viver todas as vidas e uma possibilidade que a escrita nos dá a gente pode viver impunemente todas vidas, todas as experiências de vida. A ficção é isso vai falar dentro das as possibilidades humanas sejam elas fantasiosas, o homem gosta de voar ele sonharia de voar é impossível mas por isso os heróis que voam fazem sucesso porque eles realizam a fantasia humana você se identifica com aquilo de uma certa forma. Então você tem esse primeiro momento e vejam bem uma coisa que eu acho muito importante sempre ter em mente que o escritor trabalha em dois territórios, o escritor de novela, ele trabalha com o pé muito fixo em dois territórios : o primeiro pé folhetim que é uma coisa tem um aspecto delirante, tem sim, e que faz parte da estrutura e de saber fazer de fazer folhetim mas ao mesmo tempo ele tem de ter um pé no real absoluto porque ele ta escrevendo uma coisa que não é um romance vai ser produzido tem um custo tem um orçamento. A história que ele vai contar a maneira como ele vai contar ta presa dentro de um orçamento e um escritor vai parece que ele só escreve, não ele imagina dentro de um orçamento de certa forma ele determina um orçamento porque se a personagem da sua história, a Jade, voltar pro Marrocos em uma cena que só vai ser gravada no Marrocos só pode ser gravada lá você esta determinando um custo extra para aquele orçamento que foi determinado então o escritor de novela está sempre fazendo uma ginástica porque ele esta lidando com um orçamento, ao mesmo tempo, o que é diferente de um romancista porque em duas linhas ele dá a volta ao mundo e não custa nada a ninguém. Ele está sempre fazendo essa ginástica de adaptar as condições da produção ele está sempre com a produção na cabeça, não trabalhamos criando inventando a gente inventa sempre com a produção na cabeça. Vou até da um exemplo de uma cena, que eu ainda não dei, eu estava restaurante com meu colega Carlos Lombardi estávamos jantando, Lombardi tinha feito uma cena em uma casa de vidro,a Globo tinha feito a locação em uma casa de vidro e a cena era que o mocinho corria atrás da mocinha que se escondia na casa de vidro fechava a porta o mocinho pegava uma cadeira quebrava a porta de vidro e entrava. O produtor ficou desesperado ele podia fazer essa cena mas teria de pagar a porta de vidro evidentemente e já estava esgotando o orçamento da novela, ele pergunto pro Lombardi, - Lombardi não tem jeito ele falou meu deus do céu deixa que eu resolvo e ali na mesa do jantar o que o Lombardi fez? O mocinho entra a mesma 
câmera, pega a cadeira levanta para quebrar a porta de vidro e mocinha começa colocar a mão na barriga e a gente percebe que ela esta grávida e abaixa a cadeira é uma saída do escritor é isso que eu quero dizer para vocês o escritor trabalha com a produção ao mesmo tempo. O primeiro passo é a sinopse que você entrega que é uma escrita técnica, ao mesmo tempo que ela é imaginativa ela é técnica porque ela é um ponto de partida de toda a produção, ali o diretor ao pegar aquela sinopse ele vai escolher a equipe escolher qual é o figurinista, por exemplo se é uma novela de época se é uma novela moderna, qual é o figurinista que tem as características que se adapta mais a esse tipo de coisa. O diretor pegando aquela história criação do diretor vai começar a partir daí, ele vai saber com que tom eu vou contar essa história, com que tom eu vou mostrar essa história ele vai decidir esse tom com que tom ele vai contar como é que essas personagens vão se mover em cena que características visuais eu vou dar a elas, esse é o segundo momento. Então todo o ponto de partida da produção vem daí. A casa vai ter uma ideia de quando vai se gastar com aquela novela um orçamento vai ser feito em cima dessa sinopse, então ela é uma escrita absolutamente técnica. Eu trouxe para vocês porque eu achei que poderia ser interessante a página de apresentação, por exemplo, do Clone eu sempre faço uma página de apresentação na minha sinopse, mas essa pagina de apresentação nada tem a ver com a escrita técnica é apenas ao invés de explicar de um por um porque eu acho que essa história é interessante de ser contada eu escrevo e já introduzo na sinopse mas depois dessa escrita que começa o que a gente chama de sinopse é onde você vai escrever a história em linhas gerais depois você vai fazer uma relação de cada personagem descrevendo as características de cada uma e nisso você vai se basear para escolher os atores certos para viver aquela história e nisso o figurino vai se basear e nisso o cenógrafo vai se basear porque todas essas funções contam a história, uma pessoa é o que ela veste também e onde ela mora também, né?

Nas novelas você tem de deixar isso muito claro onde é que os personagens, qualquer personagens principalmente os de novela elas são muito expostas a personagem da ficção ela é exposta, porque elas não podem guardar essa nebulosidade que o ser humano tem porque você precisa entende-las, você precisa entender quem ela. Você vê que os personagens na ficção elas sempre falam de si elas sempre se desnudem, falam ou em uma forma de se vestir elas vão sempre definindo para você ou através do figurino ou através do cenário ou através da fala todas essas coisas cada uma a seu tempo há uma exposição necessária na personagem de ficção e por isso que você pode descrever o personagem de uma forma que você não 
compreende o ser humano que está do seu lado, essa exposição é necessária. Você tem tudo isso na cabeça quando vai escrever, quando vai escrever o folhetim quando ele coloca o sensacional acima do racional ele faz isso porque o nosso objetivo é fazer com que o público ligue a tevê no dia seguinte e para que ligue a tevê no dia seguinte é preciso você soltar a sua imaginação num terreno onde é possível ao mesmo tempo com olho na produção e nas possibilidades disso, do ator que você tem você tem de estar atento as possibilidade daquele ator você não pode dar ao ator o tipo de representação que não seja a dele, porque as vezes o ator é maravilho mas le não faz determinada ... Todo mundo não faz tudo então você tem de escolher os atores de uma forma adequada e assim é.

Eu acho que agora vamos conversar que é melhor né? Já dei uma geral, quais são as curiosidades por favor?

Pergunta (Anna Maria Balogh - Eca-Usp): Eu queria que você comenta-se um pouco isso porque as vezes você aborda situações extremas do ser humano, como desaparecimento de crianças, como a questão das drogas que foi extremamente forte mas se a gente tiver um mundo onde só há desafios que é muito difícil de a pessoa vencer. Como fica a organização do roteiro entre a felicidade e a luta entre o delírio do folhetim e a continuidade do real na novela? Como você consegue fazer a mágica de unir esses elementos e cativar os espectadores?

Glória Perez: Ana, essa máxima já vem de Balzac, Balzac dizia isso felicidade não tem história tanto que todos os romances terminam quando eles são felizes para sempre, não é verdade? Realmente felicidade não tem história, as novelas são a busca da felicidade quando você chega lá a história acabou porque começa uma outra história há equilíbrio, eu vou falar para você primeiro dessas campanha para depois falar do equilíbrio . E falo muito a vontade porque fui eu mesma que introduzi pelo menos nas novelas aqui do Brasil essa mistura da realidade com a ficção, mas eu fiz isso como? Eu comecei a observar, como eu disse para vocês, a ficção lá do século XIX, o folhetim do século XIX e ai eu vi, bom hoje a gente olha para essas obras de Balzac que foram feitas para o folhetim e ai tem conde parecem figuras tão fictícias mas não eram figuras de um mundo à frente de um capitalismo á frente e eram tão fortes tão reais que Marx usou no Capital para dar exemplo de como funciona o capitalismo através de situações descritas em Balzac, ele foi buscar no romance no folhetim a pintura 
destes tipos. Eu falei bom é possível falar do cotidiano da realidade e ao mesmo tempo você estar contando uma história folhetinesca junte-se a isso um país onde as instituições são frágeis mais tão frágeis que as pessoas esperam das novelas coisas que são destas instituições. Nós somos cobrados por exemplo de educar e novela é entretenimento. Se você sabe que pode fazer a mais do que isso você faz mas eu acho triste quando recebo cartas e recebo muitos pedidos até de detetives e essa foi a carta que mais me impressionou recebo de um estado brasileiro pedindo para retratar a situação terrível que eles vivem quando em um país as categorias tem de pedir socorro ao contar de história a coisa está esquisita não é? A novela tem essa função também eu acho que, eu não queria abrir mão dela então a primeira campanha que eu fiz foi em Carmem era uma campanha da AIDS. Na época as pessoas acham que Aids era uma doença que pegava em homossexual quase que um castigo divino e que podia pegar até pelo ar se você chegasse perto ou desse a mão. As pessoas tinham um pavor um tinham medo horroroso de chegar perto de algum portador porque não podia tomar na mesma xícara era um afastamento o portador do vírus ficava num isolamento total. Eu procurei o Betinho e fiz uma história onde não um homem pegava Aids mas uma mulher porque se achava quer não dava em mulher era coisa de homossexual, uma mulher pegava Aids em um transplante de sangue os vizinhos todos se afastavam dela, transplante não transfusão, os vizinhos todos se afastavam dela ninguém chegava perto e ai ela ficava desesperada e procurava o Betinho e ai o Betinho ia ,o próprio Betinho foi ,na casa dos vizinhos e ele explicava pros vizinhos não pega assim não é assim, explicava como era e teve aquele retorno muito grande ai em torno do preconceito. Ai chegavam cartas dizendo cheguei perto de um amigos de quem eu tinha me afastada e deu uma abraço nele, coisas que compensam. Ai você tinha me perguntado essa é a realidade como no caso das crianças desaparecidas que a mãe da novela se sentava na escadaria e abria espaço para as mães reais fazerem seu apelo e nos encontramos cem crianças, mais de cem crianças só durante a novela fora o que foi encontrado depois quando a campanha pegou. Se você faz esse tipo de campanha porque isso é muito perigoso eu inventei de fazer isso na novela mas eu acho perigoso você tem de estar dentro do limite você não pode perder a mão em momento algum e essas campanhas tem de estar absolutamente vinculadas a história que você esta contando senão você para a história faz uma propaganda começa outro programa. Você não pode falar teoricamente é muito chato e cai naquilo que é mais chato que é o politicamente correto que por si é insuportável e não combina com a televisão. Eu procuro sempre fazer histórias, por 
exemplo, vamos pegar o exemplo que você pegou das mães dos desaparecidos, como isso foi abordado essa campanha? Na novela tinha uma personagem que o público gostava estava acompanhando aquela história e o filho dela sumia, você está interessado mas eu tinha passado, eu pessoa, na Cinelândia e vi uma cena horrorosa que as pessoas não prestavam a atenção eram mulheres muito pobres segurando papeis menores do que este aqui assim, toda segunda-feira elas estavam lá, ninguém olhava para elas e esse apelo era para ver se alguém que passava e olha-se teria a sorte de ter visto aquela criança que ela estava procurando. Eu pensei, meu Deus, isso só depende de divulgação se estas crianças não estão mortas alguém viu em algum lugar né? Então vamos arrumar uma maneira de colocá-las na trama que não é dizendo tantas crianças desaparecidas no país, que ai é um saco, se você puser a personagem que perdeu um filho ela era pobre ai ela passa todo o trajeto que eu fui conversar com as mães e vi o que as mães passavam chegar na delegacia o delegado ta acompanhando - a criança tinha 4 anos - essas mães reais chegam na delegacia, eu to falando da mãe real mas na ficção foi igualzinho e diz que uma criança de 4 anos sumiu. Ai o delegado responde só pode ser dado como sumido diante da lei depois de $24 \mathrm{~h} / 48 \mathrm{~h}$ depois desse tempo já levaram a criança, mataram já fizeram qualquer coisa não adianta mais procurar então a mãe ficava naquela angustia pavorosa sem ter o que, sabe, e toda essa angustia batendo na porta dos jornais para ver se a imprensa fazia alguma coisa, ela era mais uma sentada ali nas portas pedindo para publicarem aquele retrato que ninguém publicava então a nossa mãe da novela vive essa angustia vivia essas mesmas coisa e quando ela abria espaço para mãe real, já estava tão dentro da emoção do público aquela história porque aquela história tinha entrado a partir da história da novela não era uma interrupção na novela para falar de uma tema. Eu acho que a campanha novela muito perigosa muito difícil de se fazer e você só pode fazer se for uma necessidade sua eu faço, por exemplo, para satisfazer meu espírito de justiça talvez seja por isso que eu comecei mostrar falando de onde eu vim talvez por eu ter vindo de um lugar que nunca teve voz e foi mostrado pela primeira vez na televisão agora em Amazônia eu seja muito sensível a essas pessoas que não tem visibilidade porque eu vim de um lugar que não tinha e até hoje não tem o suficiente tanto que quando Evo Morales falou que nos fomos trocados por um cavalo todo mundo acreditou porque ninguém aprendeu a história do Acre na escola vocês aprenderam? Nem a escola ensina a história e é uma história bonita uma história de luta é ume estado que lutou para ser brasileiro e é completamente ignorado. É nesse ponto que a história pessoal de cada escritor conduz o olhar dele para um tipo de coisa 
mas eu acho que eu faço isso pelo meu sentimento de justiça isso tem um tom seu eu faço isso porque eu acho que tenho de ser politicamente correta é completamente diferente é insuportável, eu acho. Te respondi? Não respondi a parte da fantasia né? Veja bem, eu acho que quando a novela fala por exemplo vou pegar o Clone. Mas que aspecto eu peguei, de que ponto de vista eu vi tanto que os muçulmanos ficaram satisfeitos e teve uma coisa que me impressionou muito no Clone que Israel parava para assistir o Clone eu ganhei um presente de uma judia dizendo obrigada por nos colocar em paz com nosso primos, eu estou te dizendo isso só pra você ver como acabe sendo um arego. Como você enxerga o outro eu vejo o mundo como um cacho maravilhoso onde você tem culturas inteiramente diferentes você tem pessoas que pertencem ao século passado, você tem pessoa que pertencem a séculos que ainda não chegaram não é? E me interessa muito essa mistura é isso que eu quis captar no Clone, qual é a ideia central do Clone você vai ver nessa apresentação para mim é o confronto, me impressionou a clonagem da ovelha e é claro o clone no mundo. Eu fiquei pensando no seguinte, a clonagem é o homem substituindo Deus é a criação de novas vidas então você tem essa parte do universo que é o ocidente já interpretou que Deus ta morto que substitui Deus na criação. O Clone fala de uma coisa que hoje está nos jornais já naquela época não que é mais do que a clonagem humana é o clone transgênico é você criar e não repetir uma criatura como na clonagem mas a possibilidade de criar uma criatura que a natureza não criou e uma mistura da ovelha com a vaca do homem com a galinha enfim você acaba fazendo uma fusão de tudo que num ser que ninguém sabe o que vai ser. Então eu pensei existe uma grande parte do mundo completamente subordinada a ideia de Deus, a ideia de Alá e uma outra que diz que Deus está morto que quer substituí-lo que são os novos deuses: os médicos, os geneticistas que ficam constantemente refazendo a criação humana essa é a linha central. Aí como é que eu vou retratar esse oriente? evidentemente se você tem uma linha central se você começar fazer distinção de como é no Egito como é que é no Marrocos é claro que tem variações grandes mas ai você foge do tema você começa fazer um repórter, então vamos pegar o que é comum a todos eles ao invés de você ir pela diferença você vai pelo que é comum né? E o que é comum? Uma coisa que já esta na fantasia de todos nós a dança oriental, a sedução. O que há de sedutor em uma mulher que usa véu diante de uma mulher que se descobre que é a nossa?

Toda novela é essa comparação tanto que as conversa do tio Ali com o Albieri elas sempre ficam nisso como é o ocidente como que é o oriente. Eles sempre discordam e porque 
eu fiz que eles fossem amigos para que eles pudessem discordar. O primeiro encontro da Jade com o tio , por exemplo, que ela chega de um outro país e o tio pergunta seu sangue já veio? Ela pensa já está alegre que o tio disse que ela vai fazer a faculdade e tudo e ia a gente começa a fazer o choque das diferenças. Seu sangue já veio ela não entende o que é isso no momento, depois ela entende que é a menstruação você agora vai ter de cobrir a cabeça porque a beleza de uma mulher só pode ser vista pelo seu marido e ai ela começa a ter o choque né? Que não é só nosso é deles também eu trouxe, por exemplo, fui lá varias vezes para fazer essa novela mas levei pros atores um rapaz que havia acabado de chegar de lá e ele falava português porque a família morava aqui e já falava mais ou menos muito mal mas dava para entende o que ele dizia. Ele chegou aqui no auge daquele rap que eram as thutchucas as cachorras, lembram disso? Ai a gente perguntou o que mais impressionou no país? e o que mais impressionou ele, o grande choque que ele teve ele disse assim na minha terra se eu ofender uma mulher eu sou preso aqui chamam uma mulher de cachorra e é dança e ai da pra entender como nos somos vistos. Quando eu perguntei para as mulheres cobertas do Cairo do Marrocos cobertas com aquele véu o que elas fariam se elas fossem um dia ocidentais, se elas tinham alguma fantasia a esse respeito. Deus me livre, coitada, elas tinham pena da mulher brasileira que tinha de trabalhar que não tinha nenhum homem para cuidar delas, esse choque foi que eu quis mostrar entendeu? Agora onde entra a fantasia do Clone no grande amor, o amor que dura a vida inteira o amor que é capaz de superar tudo, quem não desejaria isso ? Por mais realista que você seja que você ache que não existe o príncipe encantado não é a toa que quando a gente passa, um filme recente Uma linda Mulher o que é? A história da Cinderela e encheu os cinemas do mundo inteiro. Existem fantasias que estão ai que a gente gostaria que fossem verdades e tem grandes amores de verdade na vida, claro que a gente não topa com eles a todo momento nem com quem os viveu a todo momento mas a gente sempre conhece algum a Jade viveu um amor ideal. Ai você tema fantasia, ela dançava bonito como as mulheres gostariam de dançar, tinha o poder de sedução que todas as mulheres gostariam de ter mas isso entra como fantasia. Te respondi? Mas tentei.

Pergunta (Elizabeth Bastos Duarte - UFSM): Eu quero levantar duas questões que eu gostaria de apresentar: a primeira é a respeito da dose desse marketing social que hoje as telenovelas de modo geral e eu acho super introduzido e hoje isso aparece, às vezes, me parece que perde a dose. Mas eu já te falei também acho perigoso. (Glória) e o outro é tocar 
num ponto que á exatamente minha ultima pesquisa é a respeito do tom, em que tom eu vou contar. Eu queria te ouvir falar um pouquinho sobre o tom.

Glória Perez: Deixa eu ver se o tom que você fala é o mesmo que e entendo. O autor ele entende o seguinte, como se o país ou se você tivesse numa grande sala aqui por exemplo eu tenho pessoas que fazem mil coisas do mundo intelectual enfim. Mas eu vou contar uma história para pessoas que são crianças, pessoas sem cultura nenhuma, pessoas com muita cultura e eu quero atingir a todas essas pessoas, eu vou lhe dizer qual é a minha definição de tom a que eu consegui chegar é aquilo que eu coloco no meu texto que define o ponto de vista a partir do qual eu quero ser entendida e por tanto estabelece essa relação com o meu interlocutor eu defino dessa maneira esse interlocutor. Eu sei que vou falar para um grupo de pessoas que estão numa sala, por suposto, porque a televisão normalmente é um veículo que você assiste junto, eu vou falar para uma família que está reunida, vou falar para homens, mulheres, velhos pessoas de várias mentalidades. Então tem de criar, primeiro vem da educação, posso contar qualquer história mas num tom que não choque porque eu não quero chocar eu quero ser entendida eu quero que liguem no dia seguinte. Eu posso contar qualquer história, mas num tom que seja percebido por todos. O que eu falei no começo eu posso contar a história pondo varias iscas nela quando a gente fala, que nem estávamos falando do Clone agora dessa diferenciação entre oriente e ocidente quando a gente fala de clonagem humana quando você põe as personagens discutindo isso você está dando uma isca para as pessoas mais esclarecidas refletirem sobre o isso, vamos lá mas o que é isso? Estão refletindo muita coisa e poderiam ter refletido muito mais naquela época porque a clonagem estava ali e você ao mesmo tempo joga a isca do folhetim do amor impossível do Romeu e Julieta cujo entendimento não é familiar é cultural. Você busca várias iscas para pegar vários interesses quanto mais iscas você puser numa novela, agora o tom para mim é fundamental tudo isso dentro de uma linguagem que todos entendam quando você fala, por exemplo, quando você falar coisas que poderiam ser ditas como reflexões filosóficas você poderia ter essa conversa aqui, mas eu não posso falar para o grande público como eu falo para vocês porque não vai entender. Eu tenho que trocar em miúdos eu tenho que transformar aquilo e esse eu acho o grande desafio que me apaixona fazer é tirar aquilo do debate acadêmico e jogar para que a população reflita, democratizar uma informação. 
Pergunta: Essa não é um problema de comunicação?

Glória Perez: Eu acho totalmente comunicação, totalmente você contar, o público vai chegar a essa reflexão ou pela emoção de ver uma mãe brigando com a outra - to pensando em Barriga de Aluguel - ou vai chegar a uma reflexão que coisa interessante . No Barriga de Aluguel, por exemplo, eu fiz uma mistura de ficção com realidade assim tinha uma personagem que era um repórter enquanto as mulheres se digladiavam, quem era a mãe uma entrava na justiça contra a outra, essa personagem quer era a repórter era mandada para a rua, porque virou um escândalo público, para perguntar o que as pessoas achavam e com isso eu entrevistava gente de todas as camadas a Dona da Mangueira, ai Eduardo Mascarenhas gente de todas as camadas e foi interessantíssimo. Você acredita que tinha um médico que disse que ele sabia racionalmente que a mãe era a dona do óvulo mas para ele era dona da barriga, você entendeu? Eu acho que isso te responde quando você conta de uma forma emocional quando você comunica pelo emocional você divide, se você chegar para esse médico e disser friamente num caso de barriga de aluguel quem é mãe verdadeira? Ele vai dizer tranquilamente é claro que é a dona do óvulo, mas se ele está acompanhando uma história onde ele acompanha o sofrimento e a angustia dessas duas mulheres e vive isso com elas, ele se divide entrou pelo emocional ai ele já não pensa como médico, não é isso? Para mim é um problema de comunicação só. Qualquer história pode ser contada pode ser compreendida.

Pergunta: É um prazer estar aqui e o eu trabalho meu tema de pesquisa é exatamente o processo de criação de autores e diretores e os desafios da compreensão do processo de construção das histórias. O que você acabou de dizer que é essa tensão permanente que o criador vive entre demandas conhecidas que você chamou de processo de produção e esse desejo apaixonado de contar histórias. Uma das características das novelas é que não só é a extensão, é uma extensão que é permeada por um conjunto de interferências possíveis e que as vezes exigem reconduções no modo de contar a história. Mas mesmo assim eu observo um esforço do criador/ escritor, no caso, de buscar uma coerência nessa arquitetura no modo de contar a história. Eu queria que você comentasse os desafios que provavelmente deve ter tido em América. O modo como se constroem os sonhos dos personagens centrais, eu gosto de analisar os inícios e os finais da novela. Esse esforço de construir o sonho dos dois 
personagens centrais ao longo da história há vários comentários de que aquele casal não funcionou bem algumas coisas do gênero e no final da novela eles não ficam juntos. A leitura que eu fiz disso é que não perdeu coerência na arquitetura da história ... - Não era para eles ficarem juntos, não era mesmo, eles não acabariam juntos (Glória ) - Essa impressão que eu tive era isso que eu queria te perguntar porque do ponto de vista da análise da história os sonhos eram tão importantes para eles, então o lugar do amor por mais importante que afeto fosse ele não podia ser maior que o próprio sonho. - Exatamente( Glória) - Eu lembro que em rodas de discussão eu dizia que a história é completamente coerente independente da união ter sido colocado como possibilidade de vivencia. Eu queria que você fala-se disso dessa tensão e dessa busca dessa coerência no modo de construir a história esse poder que você procura manter na tua mão independente das interferências possíveis.

Glória Perez: Olha, uma das coisas bacanas na novela e essa possibilidade, é um exigência e não possibilidade, de ter um jogo de cintura, muita coisa pode acontecer no decorrer de uma novela. América era uma novela onde eu queria contar o drama da imigração ilegal e essa nova personagem feminina que pode se apaixonar loucamente, como uma Jade se apaixona, mas que não joga seu emprego para o alto por causa do amor, era uma novidade. O problema de América nasceu, vocês sabem disso vamos falar claramente, de uma divergência que não pode existir em obra nenhuma entre texto e direção, não pode. Não é que o diretor seja menor acho que ambos são criadores, mas é preciso que eles andem juntos porque o trabalho do diretor tem que começar a partir do texto, ele não pode ir contra o texto. Vou dizer para vocês, você escreve Alice no País das Maravilhas e o diretor que dirige isso retira a curiosidade da Alice que é o que monta uma história, não tem história, uma Alice sem curiosidade não atravessa o espelho. Eu ia contar a história de uma mulher porque me impressionou muito quando vim dos Estados Unidos, eu vim de férias, e tive contato com os imigrantes ilegais. Eu vi aquelas pessoas que atravessam o deserto em busca do sonho americano vinham pelo mar de Cuba, sem saber se iam para a morte ou para alguma ilha qualquer lugar do mundo para onde mar as levasse, em busca do sonho americano. Eu comecei a pensar sobre isso como é forte esse sonho que foi injetado no mundo pelas histórias de Hollywood, das histórias de Hollywood a ponto de fazer as pessoas arriscarem suas próprias vidas com a certeza que vão chegar num lugar. Olha, só pode viver essa história uma mulher forte na sinopse está escrito claramente Sol não chora, está escrito claramente, porque ela é uma mulher ela é uma mulher 
movida ela tem uma forma dentro dela porque ela não olha para o lado...sabe quando a pessoa tem fé numa coisa? a pessoa movida pela fé não teme. Ela tem fé minha vida vai ser diferente do que é aqui, no que ela vai no que ela consegue as condições para ir ela conhece um homem e se apaixona loucamente como uma mulher moderna ela vai tomar uma decisão: ela vai. $\mathrm{O}$ que aconteceu foi que o diretor gostou de colocar a mocinha chorando e isso quase me destrói a história. Na América não foi mudado o percurso, depois da saída do diretor ela voltou a ser montada como estava na sinopse, mas vocês não pensem que tem conflito ou que possa ter não é um jogo de poder ou menos não se deveria ser porque o diretor tem um papel importantíssimo numa história ele cria a partir dali ele só não pode criar contra, ele só não pode desmentir porque cada personagem tem algo que é mor, eu acho que Alice é um bom exemplo; se você tirar da Sol a força, uma Sol que chora por exemplo não vai resistir, sem tirar a própria saúde de ferro uma Alice sem curiosidade não atravessa o espelho.

Nós estávamos falando ontem com a Imacollata tem uma coisa que eu acho muito bacana e que é muito visível nesses seriados americanos e o casamento perfeito entre autoria e direção. Então você pega uma série como Sex and The City como os Sopranos o autor , lá o autor é produtor ao mesmo tempo, o autor escreve os primeiros capítulos há uma definição exata de como é essa personagem de que história e há um diretor que dirige os primeiros capítulos e dá um tom daquelas personagens além da personagem ele dá o tom da narrativa, se a narrativa é lenta se a narrativa é rápida. O diretor da o tom é o maestro que vai conduzindo os trabalhos que envolvem vai fortalecendo ele vai olhar figurino, vai olhar a interpretação se ta ruim se não está e ai como eu disse ele vai criar a partir do que está escrito. Ai o diretor se vocês repararem. Vejam Sex and The City as personagens estão ali definidas completamente, o autor faz uns três quatro capítulos e depois você vai mudando autor e diretor e você não percebe, tem dia que ela esta melhor tem dias que a história não tão fascinante mas você não percebe que ela mudou de mão nem na direção nem na escrita. Isso é fundamental definido que é a personagem é essa você tem que seguir isso; isso não é se submeter ao autor não essa discussão entre autor e direção tem de existir antes depois que a história vai ao ar não tem mais que mexer a equipe aceitou assim. É claro que o autor vai aceitar, quando o autor entrega uma sinopse você vai ter aquela reunião o figurinista, o próprio diretor, gente vocês não acham que esse elemento pode contribuir mas você que vai colocar quem sabe fazer uma dramaturgia é o autor o diretor não sabe como também se você colocar um diretor para pilotar uma câmera vai ser um desastre, ele também não sabe botar em cena. Você vai fazer vai até 
incorporar aquelas sugestões mas definido que é isso tem de ser aquilo senão você destrói a história, o segredo de América é esse: era um história de carma, era uma história de sonho ninguém impedir um sonho, eles não ficariam juntos isso que se não tivesse havido o extremo de transformar a mocinha numa chorona.

Pergunta: (...) É , Maria da Federal de Pernambuco. Desculpe, quando você falou da especificidade do seu trabalho, sua trajetória sublinhando tanto a sua vivência, sua experiência no Acre como a literatura de cordel mas você falou para a gente que você fez também um curso de história e ao falar sobre a novela sobre o Clone eu percebi que você fala dando um pouco de referência a esse conhecimento que você também tem. Eu acho que isso foi importante porque a história tem personagens reais que tem história extraordinária e tem também todo o cotidiano que não é retratado nessa história dos destruídos dos marginalizados que são também uma fonte importante para se pensar. Eu queria que você falasse, como é... se isso importante se essa referência ao seu conhecimento de história é importante também como é, exemplos, fala um pouco disso.

Glória Perez: Olha para mim isso é fundamental mesmo quando eu não trabalho numa obra histórica mesmo quando não existe também nenhuma referência histórica, entre aspas, porque a história Sócrates, a história não é só os grandes heróis, as grandes personalidades embora a gente tenha referencial histórico quando fala dela. Eu acho que o historiador tem um lugar que é para tempo para situar aquele homem dentro de uma cultura e aquela pessoa dentro de uma sociedade e aquela sociedade dentro de um tempo. Então por exemplo: o que é a história? A história está sempre presente, esse ponto de vista está sempre presente no que eu faço e é por isso que talvez que eu goste de sublinhar a diversidade no mundo e não o que é unânime nele. Por exemplo, percebo muito em histórias de época às vezes a gente tem de tomar muito cuidado para que a equipe não caia numa coisa assim: no Século XVIII as pessoas usavam tal roupa ai todo mundo veste aquilo, no século XVIII o dominante era esse pensamento ai todo o elenco pensa assim, é mentira tem pessoas que estão lá trás tem pessoas que estão na frente, tem pessoas que representam aquilo, tem pessoas que guardam e seguem a moda tem pessoas que não seguem. Então eu acho que o olhar de historiadora atua nas menores coisas quando você conta a tua história, atua nisso você sempre o homem no tempo e você tirar a história de sempre do ponto de vista dos heróis porque existe a história do 
cotidiano, existe a história das pessoas que não estão com as vidas retratadas nos livros como essa sociedade vê os heróis para mim eu acho mais interessante isso do que retratar o herói, embora eu tenha retratado na minissérie. Ai qual é o lado que historiador entra é como a gente sai dessa camisa de força dos feitos heróicos que fazer aquela criatura um herói e vai procurar tocar no humano para que o herói não apareça como aquela figura, eu acho horrível quando é assim. Então eu fui buscar porque o meu método é meio antropológico, eu acho que é completamente antropológico eu vou lá eu tenho de ir ao local, tenho de conversar eu tenho de sentir a temperatura daquilo. Eu fui conversar com todos os amigos de Chico Mendes as pessoas que conviveram com ele e ai encontrei na história coisas que são verdadeiras, mas que dão a ele o lado humano por exemplo lembra a história do caboclinho da mata em Amazônia? Eu vou contar rapidinho para quem não viu: porque o morador da floresta acredita que as árvores têm os seus deuses, uma coisa que veio dos índios e eles aprenderam com os índios, existem deuses entidades que protegem tanto os animais quanto as árvores porque você pode derrubar uma árvore para construir sua casa ou você poder matar um bicho para comer mas você não pode matar um animal se você não estiver com fome, você já matou um já vai comer aquele então para que matar outro? Então existe uma regulagem natural que propicia a preservação dos animais, das árvores e de tudo mais através deste temor quase religioso de ser atacado pelo caboclinho da mata. $\mathrm{O}$ caboclinho da mata é um protetor da mata então é muito comum, você via ouvir sempre muitos casos que o seringueiro conta ele dá uma surra horrível na pessoa, por exemplo, que mata um animal e não precisa, ele da uma surra de cipó e vários seringueiros apanharam e Chico Mendes apanhou também do caboclinho da mata, ele contava isso, ele já tinha caçado o que era suficiente para ele e ele matou outro bicho e ele contava a surra que ele levou, horrível. Ai ele não nunca mais matou um bicho que ele não precisava mais isso traz o humano, o Chico Mendes que tinha todo aquele jeito ele era um homem da região, ele era um seringueiro ele acreditava nas coisas que os seringueiros acreditavam. Então você busca trazer para a história esta humanidade, você não está fantasiando em cima dele.

Pergunta: É o Curupira. Isso o que é?

Glória Perez: Olha, ele talvez tenha em outros lugares uma aproximação com o curupira, mas não é bem é uma entidade mais próxima o curupira, é uma perna só né? 
Pergunta: Tem o pé para trás...

Glória Perez: Não isso com o pé para trás é outra entidade terrível que ai tem de fazer muito mais coisas é quando matar um bicho que não pode. E ai ele bate porque ai às vezes o seringueiro caça com um cachorro ai apanha o seringueiro apanha o cachorro tanto que vocês vêem a cena que é muito engraçada da surra que o Chico Mendes, da surra que o seringueiro leva em Amazônia eles botam a um giro a uma coisa mágica que acontece e que levam a surra. Esse que corresponde ao de pé para trás ele tem olho na testa também, essa é uma coisa horrível é a pior de todas as entidades essa é uma coisa eles desmaiam, pouca gente viu alguns já viram, mas é uma entidade que dá muito medo é terrível. É fácil você ter todas essas impressões na mata e o Chico Mendes era um homem da mata. A floresta tem muitos mistérios: ela não é silenciosa como as pessoas pensam, ela tem sombras ela é feita de ruídos, aquelas folham quando se mexem ela te dá uma impressão, a certeza, que viu alguma coisa. Tem animais que tem toda uma característica mágica, por exemplo, o boto, essa história do boto de que o boto seduz donzelas agora não deve ser mais assim mas quando eu estava lá, por exemplo, tinha filho de boto registrado em cartório as pessoas registravam o que era um forma de equilíbrio porque moça que entre aspas como era dito "se perdia", ela perdia o valor social ela era expulsa e só tinha o caminho do bordel então como é que ela explicava isso o filho é do boto ninguém questionava, a culpa não é dela ai ela casava normal, existe uma forma de equilíbrio nisso. E tem outro significado isso o filho do boto ele nunca fecha a mãozinha ele tem de estar sempre com uma coisa vermelha porque corre o risco que ele vire boto. Tem um seringueiro que veio até para cá trabalhar com os atores se chama Antenor muito interessante ele contava muito, muito emocionado como ele tinha um filinho de 3 anos que estava na canoa com ele e a criança caiu no rio, esses acontecimentos a criança comida pela onça, comida pelo jacaré que cai no rio são acidentes comuns de quem mora numa floresta aqui a criança é atropelada na floresta o que pode acontecer? Ser comida por um bicho a criança cair no rio morrer afogada. Então ele estava na canoa com o filinho o filinho caiu e rio é uma coisa muito perigosa porque você olhou, olhou um segundo sumiu nunca mais você acha e ele ficou desesperado ele procurava não achava a criança que a viu criança tinha morrido. Uma semana depois mais ou menos ele vai pescar ele tem de pescar para comer ele vê um boto jovem lindo atrás da canoa, seguindo a canoa, ele ficou com os olhos 
cheios d'água e dizia para mim eu tenho certeza que era meu filinho, ele tinha virado um boto. Essa percepção essa mistura o mágico na vida cotidiana essa vivência do mágico na vida cotidiana é comum, é assim e o Chico Mendes é um homem que vem disso tem de entender de onde a pessoa vem como é que ela pensa em que medida que ela está à frente, onde é que ela está igual onde ela está para trás daquele momento histórico e é assim que entra a sua visão.

Pergunta: (Claudia Mogadouro - Doutoranda ECA-USP) : (...) Agora a minha primeira pergunta é: você tem fama de escrever sozinha, você já falou que você ouve vai sentindo a temperatura, em que você se baseia para construção desse personagem para tentar atingir o máximo do público? Pode ser em relação ao jovem ou não. E a outra questão é se há interesse, o fato de você estar aqui já é ótimo para nós, você tem interesse em ler as pesquisas acadêmicas que são feitas?

Glória Perez: Veja bem, eu acho que se você tocar pelo ponto de vista da classe que pertencem àquelas pessoas você diferencia, mas se você tocar no universal você toca a todos. Então porque a Grande Família atinge todo mundo? Porque todo mundo tem uma família, ele vai em cima do universal são problemas familiares universais. Porque a Mel criou identificação tão grande nas favelas? Em cima do universal. É o sofrimento de uma mãe que tem uma filha envolvida nas drogas não interessa se ela é rica se ela é classe média, se ela é pobre tem até uma cena que eu fiz que o professor Flávio gosta muito e eu trouxe para ele por escrito que é um momento na delegacia que as três mães - a rica, a de classe média e a de classe pobre - estão sentadas no banco dividindo a mesma dor: os filhos foram presos por droga. Eu acho que quando você busca o universal. O Junior de América, por exemplo, ele podia ser um rapaz do interior de uma mãe que criava gado, mas o que se buscou nele? Não é mostrar o rapaz do interior não era isso que estava em primeiro plano, em primeiro plano era um adolescente que sentia, descobria que era gay e lutava contra isso porque não sabia como dizer para a mãe, isso é o universal isso pode acontecer em qualquer bairro. Eu acho que quando você busca tocar o universal ai você atinge e é por isso que é uma história, mesmo essas histórias, vamos falar do cinema, por exemplo, os filmes maravilhosos que se passam em culturas que não há menor intimidade conosco, às vezes vem lá de uma aldeia do Japão te 
consome porque? Os sentimentos humanos são iguais, a humanidade é a mesma quando você ao invés de focalizar as diferenças você focaliza, você mostra a diferença mas a ênfase vai ser estar naquilo que universal: a dor de perder a mãe a dor de uma perda, a dor de uma paixão a alegria de uma paixão isso é uma vivencia da humanidade inteira porque a porta é essa, ai você atinge todo mundo.

Pergunta: Como você pesquisa a etnia? Porque quando você está escrevendo não tem mais сото...

Glória Perez: Não. Eu faço da seguinte maneira como eu disse para você, você tem de se transformar eu não gosto de criticar personagem se você vai fazer a personagem que pensa de um jeito tem de entrar na pele dela, isso é o barato do escritor. Se não tiver essa paixão não adianta, então eu tenho de ir porque você não compreende se não chega perto. Então, por exemplo, que novela que você quer saber pode ser qualquer uma que eu te digo como ela foi pesquisada. Qual é a que você mais se interessa das pesquisas que eu tenha feito?

Pergunta: Eu quero saber de América...

Glória Perez: América, como eu disse para vocês meu interesse foi despertado para esse assunto, eu passei de carro para ir num shopping de férias e vi uma fila enorme maior do que todas as filas que eu já tinha visto aqui ai eu perguntei para o motorista que fila é essa? Ele disse: é a fila da imigração; ai eu comecei a pensar naquele assunto ai comecei a conversar porque eu gosto muito de conversar com as pessoas, eu vivo em muitos mundos não vivo num mundo só. Então essa convivência com vários universos é fundamental para o escritor você não pode imaginar o mundo você tem que tocá-lo tem de se misturar nele senão você não vai saber como é, uma coisa é conhecer uma cultura através de livros a outra é você ver experimentar como a pessoa se sente, como é aquilo e ter a humildade de não querer incluir aquilo na camisa de força da sua teoria porque quando a gente vê um fenômeno a gente sempre pensa sobre ele alguma coisa e a gente vai chegar perto e vai constatar se estava certo ou não. Essa humildade é fundamental para um escritor porque se você não a tiver você vai negar o real e vai escrever uma obra transforma a partir de sua forma de ver, vai ser outra coisa. Ai eu vi aquilo e comecei a perguntar a conversar com as pessoas, a mocinha que servia 
o café, por exemplo, ela tinha vindo da Argentina também de uma maneira terrível e ela tinha vendido como ela tinha se tornado cidadã americana ela precisava de dinheiro ela vendeu um casamento para um rapaz que tinha uma namorada só que eles tinham de morar juntos naquele tempo, naquele determinado tempo que a imigração exige e vai lá a imigração faz batida para ver se aquele é um casamento de verdade mesmo. Ai eu fiquei fascinada com a relação que ela me contava, imagine vocês duas pessoas completamente estranhas faziam um negocio, porque é um negócio e elas têm de morar juntas porque a imigração pode chegar qualquer momento e aquilo é essencial para vida dele e para vida dela. Ele tinha uma noiva e eles acabam estabelecendo uma relação e eles brigaram, a briga eu achei maravilhosa porque ela gritou com ele e ele falou qualquer coisa ela chorava e dizia para ele para ti eu sou apenas um papel. Então você vai se envolvendo, como que é isso? A camareira que arrumava minha cama era cubana eu lembro que Leda Nagle estava nesse hotel e eu chamei até Leda Nagle para conversar com ela também de tão impressionada que eu fiquei. A mulher era cubana, era casada e tinha filhos que ficaram em Cuba, ela veio nessas viagens desesperadas pelo mar. Em Cuba, durante 18 anos, ela foi a editora de uma revista feminina e nos Estados Unidos, há seis anos, ela arrumava camas longe do filho e do marido e mesmo assim ela achava que um dia ela ia chegar lá. Você começa a pensar que força esse sonho tem. Aí você começa a ver os grupos e fui conversar com outras pessoas que tinham vindo por mar que tinham vindo por terra. Uma coisa terrível eles atravessam o deserto onde pessoas morrem pelo caminho acontecem coisas. Aquela cena que eu coloquei acontece mesmo eu conversei com um irmão que assistiu a morte da irmã, ela foi picada por uma cobra no caminho e como é que você faz? A excursão não pode parar e a moça ia ter uma lenta agonia e solução foi dar um tiro na cabeça dela, um tiro de misericórdia. Então quando você vai... E esse rapaz estava juntando dinheiro para ir de novo porque ele foi preso voltou deixou a irmã morrer e estava juntando dinheiro para ir de novo. O que me impressionou que eles são presos, passam por tudo isso e voltam, eu voltei num avião com deportados e a maioria deles já tinha tentado várias vezes e jurava que tentaria ir de novo, era só juntar dinheiro que iam de tentar de novo. Então ao invés de criticar você fica aberto para entender isso qual é o sentimento que move essas pessoas a isso eu vim comentando coisas que me comoveram: as pessoas que guardavam a camisa com que atravessaram o mar, os sapatos com que atravessaram como referência de curso se você passou por aquilo se você sobreviveu aquilo, você vai sobreviver aqui. Eles tinham como que quase num altar essas referências em situações difíceis eles mostravam a 
camisa, eles mostravam os sapatos, falavam, eles guardavam um álbum dessa trajetória, era quase que um amuleto uma coisa. Ai, mais impressionada fiquei quando fiquei sabendo que o brasileiro, coisa que eu nunca tinha ouvido falar aqui, era o segundo povo do mundo a tentar essa travessia, eu nunca ouvi ninguém no Brasil falar disso. Eu fui na prisão, consegui falar na embaixada e consegui visitar nas prisões, vi os brasileiros presos vi como eram as prisões que foram perfeitamente retratadas em América. A prisão é daquele tipo aquário a pessoa não tem privacidade nenhuma porque a pessoa está sempre sendo vista por todos. O segredo é você conversar, é um sonho diferente... Quando você vai para uma cultura diferente também é você conversar aberto para escutar acho que o segredo é esse tem de saber escutar e ai depois que você captou o essencial... Eu levo sempre as minhas pesquisadoras, eu adoro desenvolver o trabalho sozinha, mas levo sempre a minha equipe de pesquisadores que são fundamentais para mim. Uma delas, pelo menos, vai junto desenvolver essa pesquisa quando eu começo a escrever a novela ela passa a alimenta, mas eu já sei tudo que eu preciso saber para fixar personagens do jeito certo para montar a personagem do jeito correto. Ela vai alimentar, vai ouvir história. Nos fomos até os coiotes para falar quase que batem neles uma coisa horrível, são coiotes brasileiros. Coisas que a gente não conversa, a gente não sabe, você sabiam, por exemplo, que o Brasil era o segundo povo no mundo? Quando o Jean Charles morreu foi que eu vi uma reportagem mostrando a cidade dele, que me impressionou, é uma cidade pequena que quase não tem homens porque desde que a criança nasceu os país começam a juntar dinheiro para mandar as crianças para fora. E a gente não fala sobre isso, de repente ai é outro ponto, vejam como as novelas trazem coisas, assuntos que podem nem interessar na hora, por exemplo, em América não vi as pessoas se interessarem por esse aspecto, pelo contrário, disseram que eu estava propiciando a imigração ilegal. Eu fiquei pensando, eu já teria todos os prêmios Nobel do mundo não ia sobrar para ninguém se eu fosse como certas pessoas da imprensa dizem por que eu inventei a Internet, inventei a cultura muçulmana, inventei a imigração ilegal, inventei barriga de aluguel vejam o poder atribuído a novela e essa coisa.

Você falou uma coisa muito interessante que é antes de outra pergunta, eu queria falar rapidinho porque eu acho que é importante para nós tem o olhar de desprezo para a novela que faz parte não é no caso pessoal com a novela de uma dita "intelectualidade" que eu ponho entre aspas é um olhar de desprezo para o popular onde a novela está inserida e outras coisas que são populares também. Até pouco tempo atrás, agora está mais natural, você ia numa casa numa festa de pessoas ricas jamais tocaria o samba, pagode nem pensar, toca o jazz é o 
menosprezo a tudo o que é popular. O que é natural você compreende historicamente porque toda a história do Brasil se fez sem nenhuma participação popular, não tem nenhum momento na história o Brasil que você diga o povo estava lá o povo tira a foto no final. Então você faz a independência da República a abolição, todas são coisas de gabinete...A vontade do povo não tem vontade do povo então o povo sempre foi visto assim. Isso, essa coisa que é histórica influenciou muito na maneira como essas pessoas, essa elite que teve direito à escola e tudo mais enxerga o povo. Então tem uma coisa, por exemplo, que eu sempre fiquei indignada sinceramente essa mesma elite que menospreza tudo que é popular ela vai assistir, por exemplo, seriado americano, assiste Uma linda mulher eu acho uma bobagem, uma bobagem que diverte quantas vezes vocês ouviram falar isso? É bobo, mas é divertido mas adorei. Mas o povo não pode se divertir, o povo que não tem ... só pode ter aula não é? Só pode ter aula, só pode assistir coisas que eduquem. Eles não escutam o povo, eles têm que dizer o que o povo... Essa manipulação é horrível não é? Eu acho que isso é uma coisa que nós devíamos refletir porque esse menosprezo, qual é a raiz desse menosprezo?

Pergunta (Maria Lilian (UFSM): Em primeiro lugar eu queria cumprimentar não tanto pela autora que é inequívoca, mas pela dimensão humana da Glória, por viagem de encantamento na construção da novela, acho que para mim esse momento é uma lição e como a gente pode conversar com uma pessoa que tem essa grandiosidade humana? Eu queria te perguntar assim: Nessa viagem de encantamento na arquitetura da trama, nessa busca de sonho que a novela tem, nessa dimensão humana dos personagens, como é que o autor convive com o anunciante? Que é o outro lado, ela é uma produção comercial ela precisa trazer resultado para emissora, ela precisa ser aceita introduzida, valorizada. aquele lado comercial. $O$ ibope. Não só o ibope, mas o anunciante que vai pra dentro da novela... mas isso não passa pelo autor, o autor lida com isso através do ibope o anunciante que quer entrar... Como é que funciona?

Glória Perez: O merchandising você pode não fazer se achar que... Tem autores que não querem fazer merchandising de banco porque não gostam. Você tem uma liberdade não é imposto você fazer. Tem uma maneira de a gente lidar com o anunciante que é uma maneira diferente, por exemplo, a gente não tem aquela ação direta com este anunciante a nossa 
relação com ele vem através do ibope. A gente não pensa nele quando pensa no ibope ai você pensa como contador de histórias se o teu ibope cai você pensa: não estão escutando a minha história, entendeu? A direção é que vai pensar no anunciante, mas você não pensa, você quer contar uma história que todos assistam, agora, é claro, que é uma obra comercial e você tem que saber disso. Você tem que contar a história para atingir o grande público, você não pode contar aquela história como, por exemplo, no cinema. $\mathrm{O}$ cinema usa muito isso, às vezes faz uma história não importa se vão ver, se vão ver daqui a dez anos porque um filme que não faz sucesso hoje pode fazer daqui a dez. A novela é imediata ela passa naquela hora e ela é para todo mundo assistir se as pessoas não assistem é claro que há uma cobrança nisso.

Pergunta: Eu te digo assim: o anunciante que tenta entrar, eu não sei qual é o canal, ele tenta entrar para botar um produto a novela. O merchandising.

Glória Perez: Ai o merchandising chega para você e diz que tem tal proposta você pode aceitar ou não. Se aquela proposta aquele produto que vai estar à venda possa ser contra seus princípios ou simplesmente você não quer fazê-lo você tem liberdade para não fazer, não te é imposto ou você pode fazer. Agora o merchandising também é uma coisa perigosa porque ele não pode quebrar um folhetim, eu acho que é importante que ele esteja... Ele só vale para mim se ele foi feito dentro, por exemplo: vou dar um exemplo assim eu gosto de fazer merchandising, eu tenho trabalho porque o merchandising pode vir pronto se você quiser, mas eu não quero eu que faço que produzo, porque eu não quero que saia em nenhum momento você pode quebrar o encanto da história porque você afasta o público naquele momento, a televisão é um aparelho que já concorre com coisas demais com telefone com cotidiano com tudo em volta, então tudo que você puder fazer para não quebrar esse ilusão você tem que fazer. Então vou te dar um exemplo de um merchandising que eu fiz que eu acho que é dentro da história: era uma aluna que era apaixonada pelo professor. Ela estava sentada numa cadeirinha e ela estava desenhando o professor que estava escrevendo ali no quadro. Ela ia passar um bilhetinho para uma colega falando dele na hora que o professor de volta e vai chegando perto - era o merchandising da sandália Melissa - ai o que ela faz? Ela joga no chão e pisa em cima, mostrou a Melissa, mas está dentro da história. Você não partiu para mostrar aquele pé que não tem nada a ver que fica óbvio você fica irritado, não pode. $\mathrm{O}$ produto, nada, pode romper acho que o trabalho é esse da gente, você pode fazer o 
merchandising social o merchandising comercial desde que você não rompa em momento nenhum a fantasia e quando mais sublime ele for, mais competente ele é. 
ANEXO B - Transcrição de entrevista de Glória Perez realizada pelo autor em 30 de junho de 2003. 


\section{TRANSCRIÇÃO DE ENTREVISTA}

Glória Maria Ferrante Perez é autora de novelas na Rede Globo de Televisão. Iniciou sua carreira em 1979 quando escreveu um episódio da série Malu Mulher. Atuou como colaboradora na novela Eu prometo (Globo, 1983). Partido Alto (Globo, 1984). Escreveu as novelas Carmem (Manchete, 1987,), Barriga de Aluguel (Globo, 1989), De Corpo e Alma (Globo, 1992), Explode Coração (Globo, 1995), Pecado Capital (Globo, 1998) O Clone (Globo, 2001), América (Globo, 2005) e Caminho das Índias (Globo, 2009) além de ser autora das minisséries Desejo (Globo, 1990), Hilda Furacão (Globo, 1998) e Amazônia - De Galves a Chico Mendes (Globo, 2007). Entrevista realizada, em Curitiba, por telefone e gravada em estúdio de rádio em 30/06/2003.

Alexandre Santos - Você busca elementos jornalísticos para fundamentar questões humanas, políticas, sociais e científicas nas suas novelas. Por que a escolha do tema da clonagem humana?

Glória Perez - O tema da clonagem humana surgiu porque desde o nascimento da Dolly, eu fiquei imaginando como seria um clone humano, como ele se sentiria no mundo e como as pessoas olhariam pra ele, por causa da questão da identidade. O tema da clonagem humana já puxou o universo mulçumano pra novela porque quando você fala em um homem criando a vida em laboratório já ti vem logo a ideia de Deus, que uma humanidade ocidental que quer superar Deus, já se declarou até que Deus está morto, tomando para si a criação da vida em contraponto com a outra parte da humanidade, a oriental, que é completamente submissa a Deus e dai a origem da palavra mulçumano, então o universo mulçumano entrou ai pra servir de contraponto a isso e quando você fala em clone, não tem como você não falar da questão da identidade, eu achei que a melhor maneira de abordar seria que esse clone surgisse no sentido de substituir alguém porque essa é a primeira ideia que as pessoas têm quando fala em clonagem, clonar alguém que já existe, dizer que fulano de tal mereceria ser clonado e tudo o mais. Então eu pensei em gêmeos que já é uma forma difícil de convivência. Pesquisei vários gêmeos, a questão da identidade é muito complicada neles e fiz com que o Diogo (...) então eu fiz com que os dois eu observei que nos gêmeos tem sempre um que é o 
dominante e o outro é o mais dependente e que aos olhos dos outros eles formam como uma figura só, isso é muito incomodativo, é muito comum por exemplo que os gêmeos não tenham nome. Pra muitas pessoas, elas se referem os gêmeos ou então se os gêmeos se chamam Diogo ou Lucas, inclusive o Lucas falou sobre isso na novela, eles falam Diogo Lucas como se fossem uma pessoa só, eles formam para os outros uma imagem única. E isso dá um conflito de identidade muito grande, então o Lucas foi construído assim como sendo aquele que era o mais subordinado, aquele que meio que não conseguia descobrir quem ele era, que já é complicado para um adolescente ainda mais quando ele é visto assim e o Diogo era aquele que dava o tom da dupla, que definia, ele se colocava mais ele era mais objetivo, mais nítido aos olhos dos outros e ai quando o Diogo morre, o Lucas entra numa crise de identidade muito grande, muito profunda, inclusive achando que o pai deveria achar que talvez se ele morresse não faria tanta falta quanto o outro, porque o outro tinha mais sensibilidade pras pessoas, ele se sentia meio que como um apêndice do Diogo.

Alexandre Santos - A gente também pode perceber essa questão da identidade na personagem Jade, interpretada por Giovanna Antonelli.

Glória Perez - Ela também sofre uma crise de identidade muito grande, mais ai vinda de uma outra motivação, eu acho que a do Lucas ela se torna mais profunda, na medida em que ela existe praticamente desde o nascimento dele, ela vai mudando de forma só, ela existe quando o Diogo existe, os sentimentos ambivalentes que ele têm relação ao irmão, que com a morte do irmão se acentua na crise que vem a seguir, então nesse momento ele perde a coragem no que ele pensava em fazer, quer dizer o gesto heróico que seria largar tudo o que ele estava disposto a realmente a fazer e enfrentar uma vida nova ao lado da mocinha da Govanna (Jade), ela tinha se oposto a isto, mas a falta do Diogo faz com que ele não consiga mais se definir, se auto definir, ele entra numa crise de identidade profunda, então ele fica mais dependente do pai, da aprovação do pai e ai como ele não sabe quem ele é, elecomeça a querer ser o Diogo, ele começa a vestir a roupa do Diogo, ele começa a mudar o penteado dele pra igualar ao Diogo. E um pouco até encorajado pelos outros, porque na medida em que ele tomou a atitude ou ele faz alguma coisa que seria típica do Diogo, ele sabe que ele teria a aprovação, ele se senta mais gostado do que sentiria antes. Os outros também não sabiam 
quem ele era, nunca ninguém parou pra olhar pra ele, nos sentimentos dele, pra perguntar como ele se sentia.

$\mathrm{Na}$ verdade esta clonagem de substituição é uma grande ironia, talvez seja a forma mais cruel da ausência. Você tem a figura física da pessoa, mas a pessoa não ta ali, então o Léo que foi feito pra lembrar o Diogo, de repente ele se torna também a morte do Diogo viva diante de todos eles, eles passam a não conseguir enterrar o Diogo, a coisa acontece ao contrário, porque o Léo não reproduz nem o Lucas, nem o Diogo ele é só a figura física e é claro quem faz a pessoa é a sua história, o Léo tem uma outra história de vida.

O Diogo e o Léo foram criados com uma super proteção paterna com um pai que era super autoritário e que nunca parou muito pra perguntar o que eles queriam, na verdade eles foram criados pra seguir um modelo que o pai tinha na cabeça e o pai muito forte, é uma personalidade forte muito presente nisso, o Diogo de certa forma sofre menos com isso porque ele naturalmente é mais adequado a estas expectativas, ele nasceu mais parecido com que o pai queria para os dois. E o Lucas não, o Lucas tem um temperamento poético, na verdade ele poderia ser um músico como ele queria ser, ele tinha talento pra ser músico, mas o pai achava que ninguém vivia de música, que isso era uma bobagem, que eles tinham uma empresa pra levar adiante e que esse era o destino deles, então nesse ponto o Diogo tem mais sorte, porque o Diogo nasceu parecido com as expectativas do pai, naturalmente ele era parecido e o Lucas não, o Lucas foi muito violentado nesse sentido. As qualidades deles não eram percebidas, eram enxergadas como defeito porque eram sempre enxergadas do ponto de vista onde não corresponde ao meu sonho paterno. E léo já teve uma criação absolutamente diferente porque o Léo não tem nenhum tipo de amarra, ele é completamente independente desde criança da mãe, da avó, não tem a figura paterna ali , por isso que eu fiz o Léo desaparecer, por isso que eu fiz a deusa ir embora, exatamente para que o léo tivesse uma vida completamente diferente porque a ideia do albieri era reproduzir ao máximo a criação para que o Diogo teve, porque o que o Léo, o que o Albieri pretendia era recriar o Diogo, por isso é que o Léo também quando tem sua crise de identidade, ele fala que ele não é nada pra ninguém, essa é a crise de identidade mais profunda, porque para o avô que diz que o ama tanto, ele é o filho perdido. Pro irmão ele é o duplo no espelho, pro Albiéri ele é a recriação do afilhado que ele gostava tanto que ele achava que era o filho que ele não teve, enfim ele era, ninguém olhava pra ele indiretamente, ninguém queria saber quem ele era, então no Léo a questão da identidade chega ao máximo, chega ao ápice. 
Alexandre Santos -A inserção de personagens não ficcionais na trama (os parentes de vítimas das drogas, por exemplo) requer cuidados especiais para que o público não confunda ficção com realidade. Comente esta escolha e a forma de condução.

Glória Perez - Em primeiro lugar eu achei que devia falar sobre a droga porque era o problema do momento, eu percebi que as pessoas ou tinham em casa alguém com a dependência química ou elas viviam com esse fantasma rondando, morrendo de medo que um filho que alguém de sua família se envolvesse nisso. Eu achei que era hora de falar sobre isso. Mas daí eu comecei a pensar como é que eu vou abordar este assunto. Eu já tinha escutado todo mundo falar sobre dependente, a polícia falava, o sociólogo falava ,o psicólogo falava, mas a gente não escutava a voz deles. Eu comecei a conversar com alguns e resolvi fazer a campanha só do ponto de vista deles até pra não ser moralista, não ficar assim dividida entre uma série de tendências da psicologia, da psicanálise que começam a te dizer não é por aqui , o tratamento é por aqui , a pessoa se droga por isso ou por aquilo outro. Eu achei que a coisa mais real seria deixar que eles próprios falassem de si, nada seria mais forte nem mais eficiente do que isso. Então o que que eu fiz? Procurei nas clínicas, fui até as clínicas, esse foi um trabalho que eu fiz pessoalmente, nós gravamos, eu fazia a entrevista com as pessoas, elas gravavam tipo uma hora de entrevista e depois eu mesma ia pra edição e junto com o editor editava essa entrevista, escolhia os trechos que deviam ir ao ar de cada entrevista. Geralmente eu buscava escolher trechos que tinham a ver com as situações que os personagens estavam vivendo no momento e criava também as situações evidentemente a partir dos relatos. E depois de entrevistar os dependentes, como eu vi que toda a família se envolvia naquele processo, seja de desestruturação, ou seja, também na tentativa de reconstruir os laços familiares quando ele entrava em tratamento, eu resolvi entrevistar também os país, os país e os familiares, então por exemplo a cena em que a Maysa sobre o morro pra pagar a dívida da Mel, os pais contavam isso, então eu fiz ela subindo e ai escolhia depois escolhia os depoimentos onde pais ou mães reais contavam o que era essa sensação de subir no morro pra pagar resgate de um filho. Isso tudo eu fiz pessoalmente, todos os depoimentos, eu tenho todas as fitas aqui na minha casa, evidentemente com câmera e escolhi essa linguagem de só mostrar olhos, bocas e tudo porque eles próprios não queriam se identificar e acabou que eu acho que ficou bem mais forte de que se tivessem mosrado o rosto 
e também teve uma coisa interessante, eles tinham medo de se identificar por causa do medo, do preconceito, inclusive. Mesmo assim eram identificáveis, mesmo do jeito como foi gravado, eles foram reconhecidos na rua e eu fiquei muito compensada, muito feliz porque quando passou a primeira vez, passaram os primeiros depoimentos, eu vi que se poderia identifica-los apesar por ter optado por essa linguagem e fiquei com muito medo que isso trouxe algum prejuízo pra eles, mas quando eu voltei lá na clínica pra próxima gravação, estavam todos muito felizes porque foram procurados por familiares que estavam afastados há muito tempo, pessoas na rua , pros que estavam no serviço de ambulatório que já andavam na rua e tudo, vieram se solidarizar dizendo força, você vai conseguir e acabou que essa experiência de traze-los pra novela, fez com eles sentissem uma corrente muito positiva de apoio, de incentivo a continuarem a se submeter ao tratamento.

Alexandre Santos - No ultimo capítulo de "O Clone”, a personagem Mel aparece em cena na mesma estrutura em que os personagens não ficcionais eram apresentados (em plano fechado). Por que você fez essa relação? Comente esta inversão.

Glória Perez - Isso ai foi uma opção minha de fazer que no último capítulo a Mel aparecesse como um deles, realmente como eles apareceram durante a trama inteira, dando seus depoimentos, isto estava escrito que teria que ser gravado assim. Porque é um movimento duplo, a realidade entrou na ficção com eles e depois a personagem da ficção entra de certa forma na "realidade"

Alexandre Santos - A personagem Alicinha, interpretada por Cristiana Oliveira, ao que parece, era a única personagem de O Clone que se aproximava de uma estrutura de personagem clássica, onde herói e vilão possuem características bem demarcadas. Alicinha era uma vilã, capaz de tudo para conseguir o que queria. Mas, ao contrário do que o folhetim clássico pede, Alicinha não foi punida no final da história. Comente essa sua escolha.

Glória Perez - Na verdade essas pessoas tipo a Alicinha, eu acho que basta desmascara-las, mas elas não são punidas na realidade, elas custam muito para serem punidas. Exatamente porque a Alicinha não correspondia (ao modo de vilã clássica), tinha muita gente que não achava que ela tinha cara de vilã, ela era tão boazinha, faz uma cara de boazinha, isso 
que a torna perigosa, porque a pessoa realmente perigosa não tem a cara de bruxa e cara de má , o comportamento evidentemente mal, então eu achei que desmascarar era o suficiente, mostrar que pessoas que sorriem o tempo inteiro, tão boazinhas que entendem tudo podem ser um lobo vestido de cordeiro era suficiente não precisava castigar no final.

Alexandre Santos - Quais as principais diferenças, em termos narrativos, que você apontaria entre as novelas brasileiras e as mexicanas?

Glória Perez - A novela mexicana, eu acho que ela tem uma diferença muito essencial da nossa. Elas são novelas essencialmente de trama, elas não têm o menor aprofundamento psicológico, não há a menor preocupação de nuances psicológicas nas personagens. São novelas de trama, só acontece a trama a parte psicológica não é explorada. Então se só acontece a trama as coisas são muito rígidas, essa personagem é boa, essa personagem é má e ela será assim até o fim, porque não há preocupação nesse sentido, já na novela brasileira, a gente equilibra ou procura equilibrar a trama com um desenho psicológico das personagens.

A vida é assim e os tempos convivem também, eu conheço pessoas que são do século passado, outras que estão muito a frente desse século, eu conheço gente que está em 1950, outros que pararam em 60 ou 1970. E essa mistura que é bonita. Eu sou uma pessoa que gosto muito de conhecer gente, ando por muitos ambientes diferentes, então eu conheço várias formas de olhar o mundo, que cada pessoa dependendo de onde ela ta e que tipo de vida ela viveu, ela tem uma janela pro mundo. Eu gosto muito de observar isso, então eu freqüento muitos ambientes diferentes e gosto de conhecer todo tipo de gente, é por isso que minhas personagens são variadas porque eu conheço elas de verdade.

Na novela mexicana tem uma coisa muito interessante até o Wolf quando foi dirigir o Vale Tudo quase morreu de desgaste porque eles trabalham com ponto, pra você ver como o psicológico é pouco importante. Eles não decoram o papel, eles trabalham com ponto é dificílimo. O psicológico não tem a menor importância, o que tem importância é a trama.

Alexandre Santos - Com freqüência, os formatos ficcionais de TV, como é o caso da telenovela, fazem alusão a outras estruturas de programa de TV. Como surgiu a ideia de trazer personalidades brasileiras ao bar da Jura? E com qual objetivo? 
Glória Perez - A Jura começou a fazer um sucesso incrível, as pessoas adoravam a Jura, aquele bar e tudo mais. Eu não lembro exatamente a primeira pessoa que eu levei lá por charme na novela, ai você começa a receber pedidos, eu quero ir no bar da Jura, daí eu comecei a ver por que não né? Por que não também fazer no bar da Jura uma sala de visitas, onde as pessoas passem porque aqui no Rio é assim, você vai num bar afamado, num boteco afamado que eu digo você vai sempre encontrar uma pessoa ou outra que você conhece, uma pessoa da música, uma pessoa do teatro, então achei que era um espaço interessante pras pessoas divulgarem seus trabalhos, pras pessoas serem relembradas e isso aconteceu, por exemplo o Benito de Paula que estava meio que afastado da carreira, ele voltou no bar da jura e foi um sucesso, gravou depois, coisas assim.

Você escreve para o ator, mas você não pode escrever pro convidado. Por exemplo, quando o Pelé foi, eu estava lá , então se eu tava lá, eu podia dizer alguma coisa , via mais ou menos o que ele tava dizendo e eu podia mandar alguma coisa pra pessoa responder, mas isso é uma coisa muito rara, na verdade na hora do bar da Jura , eu dava indicações de por onde a cena devia ir, por exemplo a frase com que a Jura recebia a pessoa, dava uma frase mais ou menos pra cada que dava a indicação mais ou menos pra onde eles deviam ir. Por exemplo, vai o Benito lá e ai quando sai o outro disco que saudade de você. Relembrem as músicas dele, coisas assim. Mas você tem que dar uma abertura um espaço de improviso ali que depois na edição se resolve. Mas tem que dar um espaço de improviso porque você não pode escrever pro convidado. E ai o convidado vai falar o que ele quiser e ai quando a personagem está bem marcada você pode fazer isso, não pode fazer isso nunca num começo de uma novela. Agora, a partir de um determinado momento, quando a pessoa já incorporou a personagem fica simples porque na verdade ali aquelas cenas não levavam a nada, elas se esgotavam em si. Então não era perigoso fazer isso. Porque na verdade o que os atores tinham que fazer era só dar deixa pro personagem falar de si, ou dizer uma piada no meio da fala dela coisas assim. E depois a gente acertava na edição, se fugisse, saísse da personagem, fugisse do estilo de ser agente acertava na edição.

Alexandre Santos - No Brasil, a telenovela é caracterizada como sendo "um produto de ficção de obra aberta". Com efeito, a opinião pública pode exercer algum tipo de influência no andamento da história. Que estratégias você utiliza para obter informação de aceitação de suas novelas e em que medida essas opiniões direcionam o andamento de suas 
histórias?

Glória Perez - Você sabe se uma novela faz sucesso ou não na rua, é o comentário é quando as personagens começam a virar apelido de pessoas semelhantes, é quando as pessoas repetem os bordões, é quando as pessoas falam espontaneamente da novela. Isso você sente rapidamente na rua. Né brinquedo não da Jura o cada mergulho é um flash da"outra. Cada mergulho é um flash, eu resolvi botar o Piscinão de Ramos, porque teve uma época aqui no Rio de Janeiro que todo dia que você abria o jornal tinha uma autoridade mergulhando no piscinão de Ramos, era uma coisa impressionante, então eu achei aquilo engraçado e realmente tudo era todo um mergulho é um flah, daí eu criei esse bordão pra ela e fiz ela ir no piscinão porque era uma coisa atual. Eu acho que sucesso não tem fórmula o que agrada numa novela eu acho que é a mesma coisa que desde que nasceu o folhetim continua sendo a mesma coisa, por que é o sucesso do folhetim, do velho folhetim do jornal do século XIX? É se você conseguir falar ao emocional das pessoas, porque o emocional nivela todas as classes, não depende de uma cultura de uma pessoa, o que entra pelo coração, entra pelo sentimento e a partir daí se você joga essa isca, você pode fazer campanha, partir pra coisas mais intelectuais, mesmo assim é preciso ter cuidado, por exemplo na Clonagem, eu sei que a clonagem é uma ideia meio complicada que nem todo mundo entende de cara, então eu fiz a Dalva acreditar que ele era uma reencarnação, porque quem não entendesse por um lado ia entender pelo outro. A Dalva era a pessoa mais equilibrada da família. Toda vez que eu vou fazer uma novela, eu procuro muito me antenar pro que as pessoas estão vivendo, quais são as angústias desse momento, quais são as fantasia e sonhos das pessoas desse momento, porque as fantasias e o sonhos fazem parte da sua realidade também, uma coisa que eu acho por exemplo que também foi muito apreciada no Clone numa época que as pessoas têm assim, ah! Como que está a família, a família está explodindo e tudo o mais, foi aquela estrutura familiar forte do universo mulçumano em contraponto com a família ocidental que realmente ta toda partida. 